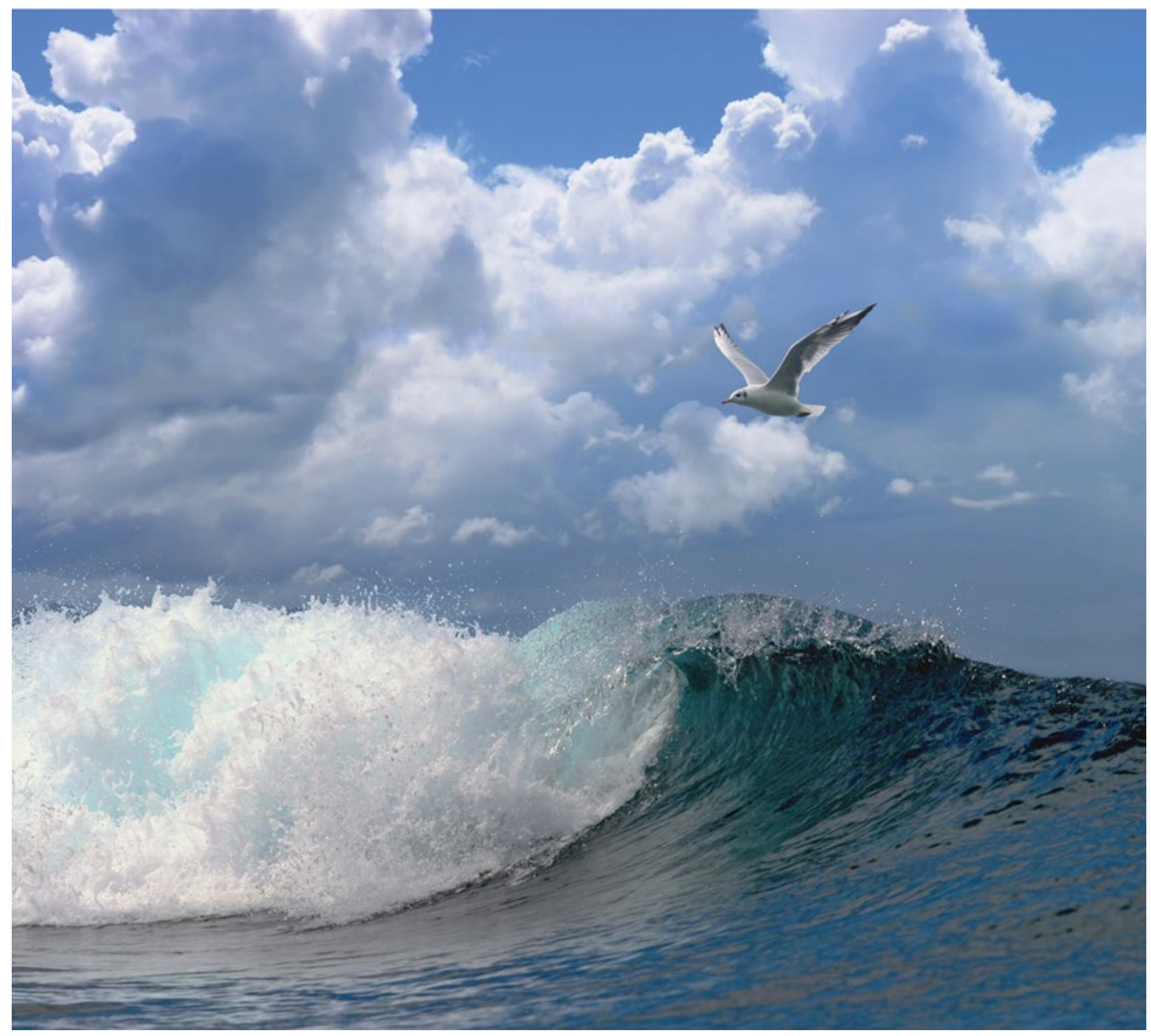

Development of a framework and toolbox for measuring and evaluating ecosystem interactions of seaweed aquaculture

Author(s): L. Tonk, H.M. Jansen, M. Poelman, R.W. Nauta, R.G. Jak, J.E. Tamis \& R.H. Jongbloed 


\section{Development of a framework and toolbox for measuring and evaluating ecosystem interactions of seaweed aquaculture}


Keywords: seaweed, ecosystem interactions, framework.

Client: $\quad$ This study was carried out by Wageningen University \& Research and was commissioned and financed by the Dutch Ministry of Agriculture, Nature and Food Quality within the context of the Knowledge Base programme 'Circular and climate neutral' (KB-34-007004).

BAS code: KB-34-007-004 Marine resources in circular climate smart food systems (KB342C-1)

This report can be downloaded for free from https://doi.org/10.18174/553741

Wageningen Marine Research provides no printed copies of reports

Wageningen Marine Research is ISO 9001:2015 certified.

\section{(C) Wageningen Marine Research}

Wageningen Marine Research, an institute within the legal entity Stichting Wageningen Research (a foundation under Dutch private law) represented by Drs.ir. M.T. van Manen, Director Operations

KvK nr. 09098104, WMR BTW nr. NL 8113.83.696.B16. Code BIC/SWIFT address: RABONL2U IBAN code: NL 73 RABO 0373599285
Wageningen Marine Research accepts no liability for consequential damage, nor for damage resulting from applications of the results of work or other data obtained from Wageningen Marine Research. Client indemnifies Wageningen Marine Research from claims of third parties in connection with this application.

All rights reserved. No part of this publication may be reproduced and / or published, photocopied or used in any other way without the written permission of the publisher or author. 


\section{Contents}

Development of a framework and toolbox for measuring and evaluating ecosystem interactions of seaweed aquaculture

Samenvatting

Summary

$1 \quad$ Introduction

2 Background for the aquaculture EIA Framework

2.1 Background 11

$\begin{array}{ll}2.1 .2 & \text { Linkage-based frameworks } \\ & 12\end{array}$

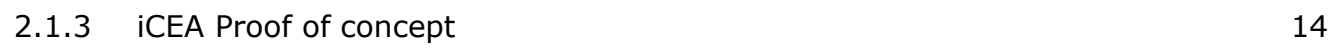

2.2 Towards a Framework development and EIA approach for aquaculture 15

3 Framework for evaluation of Seaweed farming-Ecosystem Interactions 17

$\begin{array}{lll}3.1 & \text { Ecological pressures introduced by seaweed farming } & 17\end{array}$

3.1.2 Different properties and activities of offshore versus inshore seaweed farming

3.2 Ecological response to seaweed farming

3.2.2 Seaweed interaction framework - impact chains 26

3.2.3 Impact risk of the pressures involved with seaweed farming 28

$\begin{array}{lll}3.3 & \text { Risk analysis } & 31\end{array}$

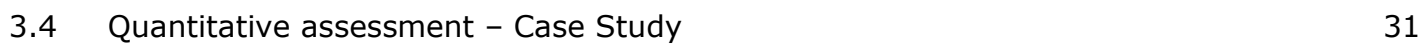

3.4.1 North Sea seaweed cultivation case study 31

3.4.2 Background information 32

3.4.3 Impact risk assessment of the pressures involved with seaweed farming in OWF's in the North Sea $\quad 32$

3.4.4 Case study results $\quad 36$

3.4.5 Case study discussion $\quad 44$

4 Development of a Toolbox for measurement of Seaweed-Ecosystem interactions 49

4.1.1 How to monitor intensity and spatial/temporal distribution of the activity 49

4.1.2 How to measure pressures and link to intensity of activity 50

4.1.3 How to measure ecosystem response $\quad 51$

$\begin{array}{lll}4.2 & \text { Recommendations for the case study North Sea seaweed cultivation } & 57\end{array}$

$\begin{array}{llr}5 & \text { Conclusions and recommendations } & 59\end{array}$

$\begin{array}{llr}6 & \text { Glossary } & 60\end{array}$

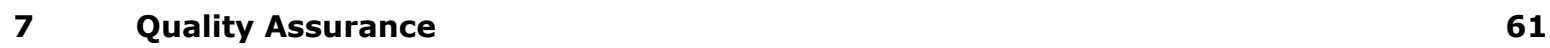

$\begin{array}{lr}\text { References } & 62\end{array}$

$\begin{array}{lr}\text { Justification } & 66\end{array}$

$\begin{array}{llr}\text { Annex } 1 & \text { Activity-pressure matrix } & 67\end{array}$

$\begin{array}{llr}\text { Annex } 2 & \text { Ecosystem component-pressure matrix } & 68\end{array}$ 
Annex 5 Overview of pressures and related ecosystem components that occur in impact risk chains 86

Annex 6 Risk ranking Campbell et al 2019 88 


\section{Samenvatting}

Grootschalige zeewierproductie in Europa heeft de potentie om in de toekomst deels als benodigde voedselbron te dienen, op voorwaarde dat dit op een duurzame wijze gebeurt. Hoewel zeewierteelt in Nederland op het moment nog kleinschalig is en voornamelijk in Zeeland plaatsvindt, biedt de opschaling van offshore windparken in de Noordzee en de intentie tot medegebruik van deze parken kansen voor grootschalige uitbreiding van zeewierproductie. Maar hoeveel zeewier kan er eigenlijk op een verantwoorde manier gekweekt worden in de Noordzee? De effecten van zeewierproductie op het mariene ecosysteem zijn grotendeels onbekend en een gestandaardiseerde aanpak voor kwantificering van deze verwachte effecten en gevolgen om ecosysteemdiensten te leveren ontbreken. Het doel van deze deskstudie is een conceptueel framework te ontwikkelen dat eventuele impacts op het ecosysteem als gevolg van zeewierboerderijen in kaart brengt. Dit framework moet toepasbaar zijn op een breed scala aan kweekmethoden en locaties in zowel offshore, als kustgebieden, met name de Nederlandse kustzone en de Deltawateren. Deze aanpak fungeert als een eerste screening om potentiële bedreigingen te identificeren en prioriteren. Deze aanpak zal een solide basis bieden voor het sturen van onderzoek- en adviesbeleid met inachtneming dat de ontwikkeling van de methode zelf een dynamisch proces is dat verder aangepast zal worden. Het uiteindelijke doel is bij te dragen aan de ontwikkeling van zeewierproductiesystemen waarbij de balans tussen voedselproductie en natuurbehoud gehandhaafd wordt.

Als basis voor het risicoanalyse-framework voor zeewierkweek is een DPSIR-benadering (driver, pressure, state, impact, response) gebruikt om de mogelijke effecten van zeewierproductie aan te duiden en te linken aan de verschillende ecosysteemcomponenten. In het framework werden in totaal 631 impactketens (combinaties van driver / activiteit - drukfacturen - ecosysteemcomponenten) geïdentificeerd. Een case study van $500 \mathrm{~km}^{2}$ zeewierkweekgebied gelijkmatig verdeeld over offshore windparken (OWF) in het Nederlandse deel van de Noordzee werd gebruikt om risico's te prioriteren en kennislacunes te identificeren op basis van een combinatie van deskundig oordeel en beschikbare gegevens. De 631 impactketens zijn in de risicoanalyse gebruikt om kennislacunes te identificeren aan de hand van een zestal aspecten (ruimtelijke omvang, spreiding, frequentie, persistentie, ernst en veerkracht). Voor elke impactketen werd het risico ingeschat op basis van semi-kwantitatieve scores zoals beschreven in Tabel i. De meeste van deze impactketens vallen in de lage risico categorie. Impactketens met een hoog risico die aandacht vereisen zijn aanvoer van zwerfvuil en de introductie van niet-synthetische stoffen en verbindingen, met name voor hogere trofische ecosysteemcomponenten (EC) (zoals vissen, vogels en zeezoogdieren) en introductie van nietinheemse soorten voor laag-trofische EC. Door de EC apart te beschouwen is het relatieve belang van extra drukfactoren met een laag algemeen impactrisico voor een bepaald EC inzichtelijk gemaakt, zoals de input van microbiële pathogenen en parasieten. Een quickscan van de betrouwbaarheid van de beschikbare informatie betreffende elke EC-drukcombinatie benadrukte kennisleemten omtrent drukfactoren, zoals de introductie van niet-inheemse soorten en het vrijkomen van productiemateriaal. Deze analyse gebaseerd op de specifieke aspecten van risico's moet worden gezien als een eerste screening om de richting van verder onderzoek aan te duiden. In-situ data verkregen door monitoring is nodig voor validatie van deze impactketens. Bovendien moet er rekening mee worden gehouden dat de generieke benadering van de risicoanalyse niet geschikt is voor concepten als draagkracht wanneer deze bepaald wordt door beschikbare primaire productie. Het overschrijden van de draagkracht is een actuele zorg die wijdverbreide effecten op ecosysteemcomponenten met zich meebrengt. De positieve effecten van drukfactoren die gepaard gaan met de activiteiten rondom zeewierkweek, zoals een mogelijke toename van de biodiversiteit, worden momenteel niet meegenomen in de risicoanalyse. Wanneer deze positieve effecten wel worden meegenomen in de risicoanalyse kunnen deze mogelijk een meer uitgebreide en evenwichtige inschatting van de risico's geven. Bovendien dient bij vervolgonderzoek (en monitoring) ook rekening te worden gehouden met de kennislacunes met betrekking tot impactketens van zeewierkweek met een hoge onzekerheid. 
Ondanks de beperkingen van het risicoanalyse-framework voor zeewierkweek beschreven in dit rapport, biedt deze aanpak momenteel de meest geschikte begeleiding voor het prioriteren van impactrisico's waarbij alle relevante activiteiten, drukfactoren en ecosysteemcomponenten betrokken worden. Verdere ontwikkeling van de assessmentmethode in combinatie met onderzoek en monitoring kan leiden tot een verschuiving in focus en prioriteit. Het risicoanalyse-framework voor zeewierkweek kan worden gebruikt in geïntegreerde cumulatieve effectbeoordelingen waarbij sprake is van druk die voortvloeit uit andere activiteiten (bijv. visserij, hernieuwbare energie) in het ecosysteem.

Prioritering van impactrisico's op basis van semi-kwantitatieve beoordelingen (met opname van kwalitatieve data indien beschikbaar) en een focus op impactketens met hoge prioriteit wordt aanbevolen en zou voor elke zeewierboerderij afzonderlijk moeten worden uitgevoerd.

Tabel i: Overzicht van drukfactoren met hoge prioriteit op basis van direct en lange termijn impactrisico (IR) (cut-off bij <2\% totale IR). Hierbij worden de Engelse termen gebruikt. Drukfactoren met een hoog algemeen IR worden weergegeven als overall Instant IR en overall long-term IR. Drukfactoren met een lage overall IR die relatief belangrijk zijn voor een bepaalde EC (gebaseerd op instant en long-term IR), worden weergegeven als 'per $\mathrm{EC}^{\prime}$. In de laatste kolom worden drukfactoren met hoge onzekerheid weergegeven als knowledge gaps.

$\begin{array}{llllll}\text { Drukfactoren met hoge prioriteit } & \text { Overall } & \text { Overall } & \text { IR per EC } & \text { Long-term } & \text { Knowledge } \\ & \text { Instant IR } & \text { long-term } & \text { IR per EC } & \text { gaps }\end{array}$

IR

\begin{tabular}{|l|l|l|l|l|l|}
\hline Introduction of non-synthetic substances & $\mathrm{x}$ & $\mathrm{x}$ & & $\mathrm{x}$ & \\
\hline Input of litter & $\mathrm{x}$ & $\mathrm{x}$ & & $\mathrm{x}$ & \\
\hline Input of anthropogenic sound & $\mathrm{x}$ & $\mathrm{x}$ & & $\mathrm{x}$ & $\mathrm{x}$ (benthos) \\
\hline Disturbance (visual) of fauna & $\mathrm{x}$ & $\mathrm{x}$ & & $\mathrm{x}$ & \\
\hline Input of light & $\mathrm{x}$ & $\mathrm{x}$ & & $\mathrm{x}$ & \\
\hline Input or spread of non-indigenous species & $\mathrm{x}$ & $\mathrm{x}$ & & $\mathrm{x}$ & $\mathrm{x}$ \\
\hline Attraction of species & & $\mathrm{x}$ & & $\mathrm{x}$ & \\
\hline Absorption of trace and heavy metals & & $\mathrm{x}$ & & $\mathrm{x}$ & \\
\hline Release of reproductive material & & & $\mathrm{x}$ & & $\mathrm{x}$ \\
\hline Death or injury by collision & & & $\mathrm{x}$ & $\mathrm{x}$ & \\
\hline Input of microbial pathogens \& parasites & & & $\mathrm{x}$ & $\mathrm{x}$ & $\mathrm{x}$ \\
\hline Input of genetically modified sp. & & & $\mathrm{x}$ & $\mathrm{x}$ & $\mathrm{x}$ \\
\hline Carbon emission & & & $\mathrm{x}$ & $\mathrm{x}$ & \\
\hline Nitrogen emission \& deposition & & & $\mathrm{x}$ & $\mathrm{x}$ & \\
\hline Barrier to species movement & & & & $\mathrm{x}$ & \\
\hline Entanglement & & & & $\mathrm{x}$ & \\
\hline Extraction/mortality/injury wild species & & & & $\mathrm{x}$ & \\
\hline Extraction of food resource & & & & $\mathrm{x}$ & \\
\hline Changes in siltation & & & & $\mathrm{x}$ \\
\hline Reduction in wave energy & & & & $\mathrm{x}$ \\
\hline Changes in water flow rate & & & $\mathrm{x}$ \\
\hline
\end{tabular}

In het tweede deel van dit rapport wordt het risicoanalyse-framework voor zeewierkweek gebruikt om aan te geven welke tools en technieken geschikt zijn voor het kwantificeren van ecologische processen op de juiste temporele en ruimtelijke schaal binnen de limitatie van de draagkracht van het ecosysteem. Een gestandaardiseerde maar gerichte monitoring op maat gemaakt voor de omvang en locatie van zeewierboerderijen is nodig om onzekerheden aan te pakken en om tot een goed geïnformeerde besluitvorming te komen. In de komende jaren worden de voorgestelde technieken om veranderingen in en rond aquacultuurbedrijven vast te stellen verder ontwikkeld en getest. De ontwikkeling van deze innovatieve technieken zal bijdragen aan monitoringprogramma's ter ondersteuning van een duurzaam beheer van mariene hulpbronnen. 


\section{Summary}

Large-scale seaweed aquaculture in Europe has the potential to meet part of our future resource needs provided that it is done sustainably. Although the development of seaweed farming in the Netherlands is still at an early stage, the rapid upscaling of offshore wind farms in the North Sea creates opportunities for seaweed aquaculture in a multi-use environment. The impacts of seaweed farming on the marine ecosystem however are largely unknown and a standardized approach for quantification of expected impacts and their consequences on the capacity to supply ecosystem services is lacking. The aim of this desk study is to develop a conceptual framework that will map potential ecosystem impacts caused by seaweed farms. This framework should be applicable to a wide range of cultivation methods and locations in offshore areas, specifically the Dutch coastal zone and Delta waters. It should be applied as a first screening to identify potential threats that (albeit still a work in progress) should provide a solid basis to direct science and advice policy. The ultimate goal is to contribute to the development of seaweed cultivation systems balancing trade-offs between food production and nature conservation.

A risk assessment framework for seaweed aquaculture was created based on a DPSIR (driver, pressure, state, impact, response) approach to describe the activities related to seaweed farming (drivers) and the potential impacts that apply to the different ecosystem components involved. A total of 631 impact chains (driver/activity - pressure - ecosystem component combinations) were identified in the seaweed framework. A case study of $500 \mathrm{~km}^{2}$ seaweed cultivation area assumed evenly spread over offshore windfarm (OWF) areas in the Dutch part of the North Sea was used to prioritize risks and identify knowledge gaps based on a combination of expert judgement and available data. The 631 impact chains were used in the risk assessment based on expert judgement of six aspects of risk (spatial extent, dispersal, frequency, persistence, severity and resilience) to identify knowledge gaps. For each impact chain, risk was estimated based on semi-quantitative scores as compiled in Table i. Most of these impact chains fall into the low risk category. High risk impact chains that require attention include the potential impact of pressures such as input of litter and introduction of nonsynthetic substances and compounds on higher trophic ecosystem components (i.e. fish, birds and marine mammals) and introduction of non-indigenous species for low trophic ecosystem components. When ecosystem components (EC) are considered separately, the relative importance of additional pressures (which would otherwise not be identified due to the low overall impact risk (IR) (Table i)), such as input of microbial pathogens and parasites to low trophic ECs are identified. A quick scan of the confidence in the available information for each EC-pressure combination emphasized knowledge gaps on pressures such as on the introduction of non-indigenous species and release of reproductive material. This assessment based on the specific aspects of risk should be seen as a first screening to guide further science. Validation of these high priority impact chains is required and necessitates further input of data from monitoring. Moreover, it should be taken into account that the generic approach of the assessment is not suitable to deal with concepts such as carrying capacity (when determined by available primary production), a current concern that entails widespread effects on ecosystem components. Activities that result in pressures with a positive effect, such as a potential increase in biodiversity, are currently not taken into account in the impact assessment but have the potential to provide a more comprehensive and balanced estimate of risks when incorporated. Additionally, key knowledge gaps related to seaweed farming impact chains with a high uncertainty should also be taken into account in exploratory investigations.

Taking into account the limitations of the risk assessment framework for seaweed aquaculture as described here, currently provides the best guidance for prioritization of impact risks that involve all the relevant activities, pressures and ecosystem components. Further development of the assessment method accompanied by research and monitoring may lead to different outcomes. We emphasize that the current risk assessment framework can be applied in integrated cumulative impact assessments involving pressures that stem from other activities (e.g. fisheries, renewable energy) in the ecosystem. Prioritization of impact risks based on semi-quantitative assessments (with inclusion of 
qualitative data when available) and a focus on high priority impact pathways is recommended and could be performed for each seaweed farm individually.

Table i: Overview of high priority pressures based on instantaneous and long-term impact risk (IR) (cut-off at $<2 \%$ total IR). Pressures with a high overall impact risk are depicted as overall instant IR and overall long-term IR. Pressures with a low overall IR that are relatively important to a particular ecosystem component (EC) (based on instantaneous and long-term IR) are depicted as 'per EC'. In the last column pressures with high uncertainty are shown as key knowledge gaps.

High priority pressures

\begin{tabular}{|c|c|c|c|c|}
\hline Overall & Overall & IR per EC & Long-term & Knowledge \\
\hline Instant IR & long-term & & IR per EC & gaps \\
\hline
\end{tabular}

\begin{tabular}{|c|c|c|c|c|c|}
\hline Introduction of non-synthetic substances & $x$ & $\mathrm{x}$ & & $x$ & \\
\hline Input of anthropogenic sound & $x$ & $x$ & & $x$ & $x$ (benthos) \\
\hline Disturbance (visual) of fauna & $x$ & $x$ & & $x$ & \\
\hline Input of light & $x$ & $x$ & & $x$ & \\
\hline Attraction of species & & $\mathrm{x}$ & & $x$ & \\
\hline Absorption of trace and heavy metals & & $\mathrm{x}$ & & $x$ & \\
\hline Release of reproductive material & & & $\mathrm{x}$ & & $x$ \\
\hline Death or injury by collision & & & $\mathrm{x}$ & $x$ & \\
\hline Carbon emission & & & $\mathrm{x}$ & $\mathrm{x}$ & \\
\hline Nitrogen emission \& deposition & & & $\mathrm{x}$ & $x$ & \\
\hline Barrier to species movement & & & & $\mathrm{x}$ & \\
\hline Entanglement & & & & $x$ & \\
\hline Extraction/mortality/injury wild species & & & & $\mathrm{x}$ & \\
\hline Extraction of food resource & & & & $x$ & \\
\hline Changes in siltation & & & & & $x$ \\
\hline
\end{tabular}

In the second part of this report the risk assessment framework was used to outline which tools and techniques are suitable to quantify ecological processes at the appropriate temporal and spatial scale within the limitations of the carrying capacity of an ecosystem. A standardized but targeted monitoring tailored to the extent and location of seaweed farms is needed to ensure that uncertainties are addressed and informed decision-making is facilitated. In the coming years, the suggested techniques will be further developed and tested. Further development of innovative techniques to determine changes in and around aquaculture farms will contribute to monitoring programs to support management of marine resources. 


\section{Introduction}

With 6\% annual growth since 2010 aquaculture is one of the world's fastest growing industries and is likely to increase in importance in terms of providing biomass to sustain the world's food production. Chile, China and Norway are the leading producing countries for wild seaweed species (in order of decreasing rank) while China, Indonesia, Korea and the Philippines are leading producing countries of cultured species (FAO, 2018). The development of large-scale seaweed aquaculture in Europe has the potential to meet part of future resource needs, provided that this is done sustainably (Campbell et al., 2019). With the rapid upscaling of offshore wind farms (OWF's) in the North Sea, opportunities are created for offshore aquaculture in a multi-use environment. However the development of offshore aquaculture is still at an early stage and the impacts of seaweed farming on the marine ecosystem are largely unknown. Sustainable exploitation of marine resources is therefore compromised. Appropriate management needs decision-support tools that can deal with the complexities involved.

Previous observations suggest that seaweed farming provides a variety of ecosystem services such as biodiversity enhancement, carbon sequestration and a decrease of high nutrient levels (Hasselstrom et al., 2018). However, the large-scale production of seaweed can also have potential negative impacts on marine ecosystems. For instance, growing seaweeds take up nutrients from the surrounding environment. While this may be beneficial in nutrient-enriched areas, it can lead to competition for nutrients with wild local seaweed communities, seagrass or microalgae when nutrients are scarce (Tonk and Jansen, 2019).

\section{a. Problem definition}

Although many of the ecosystem interactions involved with seaweed farming have been identified, a standardized approach for quantification of expected impacts and their consequences on the capacity to supply ecosystem services is lacking.

i. Target groups: governments as area manager, aquaculture companies, OWF operators and fishermen being potential users of the provided knowledge to optimise their business case.

ii. Knowledge: the project will lead to knowledge and tools to manage and optimise multiuse of OWF's aiming at seaweed cultivation in particular and aims at being applicable for aquaculture in general.

\section{b. Objectives}

The aim of this desk study is to develop a conceptual framework that will map potential ecosystem interactions in and around impacts caused by seaweed farms. This framework should be applicable to a wide range of cultivation methods and locations in offshore areas, specifically the Dutch coastal zone and Delta waters. In addition, this study will provide a first screening to prioritize potential threats based on expert judgement. The framework will be used to outline which tools and techniques are suitable to quantify the ecological processes at the appropriate temporal and spatial scale. If no suitable techniques are yet available, we will propose innovative tools and techniques that should be developed (in coming years) for efficient monitoring of aquaculture-environment interactions. This study will thus outline the conceptual framework and suggest a toolbox on how to measure ecological processes related to seaweed aquaculture. The aim is to use this framework over the coming years, at 
a point in time when seaweed aquaculture is more developed, to quantify and evaluate the aquaculture-environmental interactions in a standardised manner.

Tasks involved:

1. Background for the conceptual framework: This task will provide background of linkage frameworks and approaches suggested in literature for evaluation of cumulative effects of human activities (such as fisheries) in marine ecosystems. These include impact chains (DPSIR pathways: driver>pressure >state > impact>response) coupled to cumulative effect analysis (CEA), which will be used to develop the seaweed-ecosystem-interactions framework.

2. Framework for Environmental Interactions of Aquaculture: This task will develop a conceptual Framework by applying DIPSR and CEA approaches to aquaculture and outline which ecological processes are affected by the farming activities. A case study was chosen to perform a semi-quantitative assessment to prioritise impact risk of seaweed cultivation in the North Sea.

3. Toolbox suggesting best measures: This task aims to provide an overview of existing and new innovative tools and techniques suitable/required to quantify Seaweed-Environment interactions at the appropriate spatial and temporal scale. 


\section{Background for the aquaculture EIA Framework}

\subsection{Background}

The growing demand for seaweed biomass necessitates knowledge about the various ecosystem interactions of seaweed cultivation in the marine ecosystem at play, to ensure a sustainable development of this expanding industry. To warrant that human activities are carried out in a sustainable manner, numerous international maritime policies have been implemented, such as the European Union 'Water Framework' and 'Marine Strategy Directives' (Commission, 2008, Council, 2000). Assessment of the impacts involved with human activities is needed to meet policy goals.

\subsubsection{Environmental Impact Assessments (EIA)}

Worldwide, Environmental Impact Assessment (EIA) is the most commonly utilised tool for evaluating environmental concerns, sustainability issues and developing mitigation measures for new development projects. EIA is defined as the process of identifying, predicting, evaluating and mitigating the biophysical, social, and other relevant effects of development proposals prior to major decisions being taken and commitments made. EIA was initially developed for large development projects such as the building of dams, but has since been adapted for aquaculture (FAO, 2009). In the early days of EIA, impact assessments focussed on a single activity or target species (Knights et al., 2015). Later, the need for a more comprehensive method was recognized in which the network of impacts is identified and managed, which offers a solution to the management of marine resource exploitation whilst conserving the marine ecosystem (Piet et al., 2015). This is also known as ecosystem-based management (EBM).

The pathways through which activities cause harm are identified using conceptual frameworks such as Pressure-State-Response (PSR), Driving force-State-Response (DSR) or Driving force-PressureState-Impact-Response (DPSIR) (Figure 1). These frameworks are used to describe the impact chain, linking driver-pressure-state (equals: human activity-pressure-ecosystem component, Figure 2) that causes the specific impact. With the increase of human activities in the marine environment (such as the energy sector, shipping, aquaculture and fisheries) exploiting a variety of marine habitats and species, single chains of causal links are expanded to multiple chains forming more complex networks of interactions (Figure 2).

Table 1: DPSIR definitions taken from ODEMM website (Options for Delivering Ecosystem-Based Marine Management) and Piet et al. (2017a).

\begin{tabular}{|c|c|}
\hline Word/Phrase & Definition \\
\hline Driving force & $\begin{array}{l}\text { According to DPSIR driver or 'driving force' is a need. Examples of primary driving } \\
\text { forces for an individual are the need for shelter, food and water, while examples of } \\
\text { secondary driving forces are the need for mobility, entertainment and culture. Here } \\
\text { the driver is defined by the sector and activity (ODEMM). }\end{array}$ \\
\hline Pressure & $\begin{array}{l}\text { The mechanism through which an activity has an effect on any part of the } \\
\text { ecosystem. Pressures can be physical (e.g. abrasion), chemical (e.g. introduction of } \\
\text { synthetic components) or biological (e.g. introduction of microbial pathogens) } \\
\text { (ODEMM). }\end{array}$ \\
\hline State & $\begin{array}{l}\text { According to DPSIR the 'state' of the environment is the quality of the various } \\
\text { environmental compartments (air, water, soil, biota etc.) in relation to the } \\
\text { functions that these compartments fulfil. The 'state of the environment' is thus the } \\
\text { combination of the physical, chemical and biological state. }\end{array}$ \\
\hline
\end{tabular}




\begin{tabular}{|l|l|}
\hline Impact & $\begin{array}{l}\text { A measurable, detrimental, change to a species or habitat attributable to a human } \\
\text { activity. Thus "Effects" can be managed through the mitigation of human activities } \\
\text { to reduce or prevent "impacts". This embodies the consideration of environmental } \\
\text { risk in that whilst human activities exert pressures they do not always impact the } \\
\text { environment. For example, various human activities exert pressures on the marine } \\
\text { environment through increased nutrient loading resulting in effects of oxygen } \\
\text { depletion/hypoxic zones, such effects can be magnified into impacts (e.g. } \\
\text { reproductive problems in fish) (Judd et al., 2015). }\end{array}$ \\
\hline Response & $\begin{array}{l}\text { According to DPSIR a 'response' by society or policy makers is the result of an } \\
\text { undesired impact and can affect any part of the impact chain (ODEMM). }\end{array}$ \\
\hline
\end{tabular}

(a)

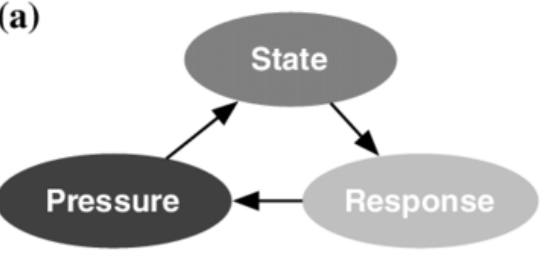

(b)

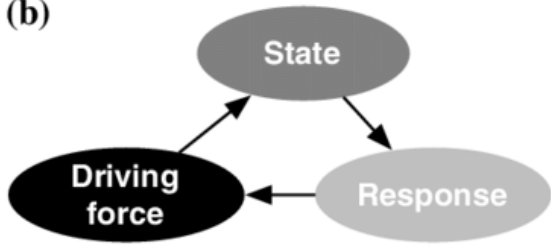

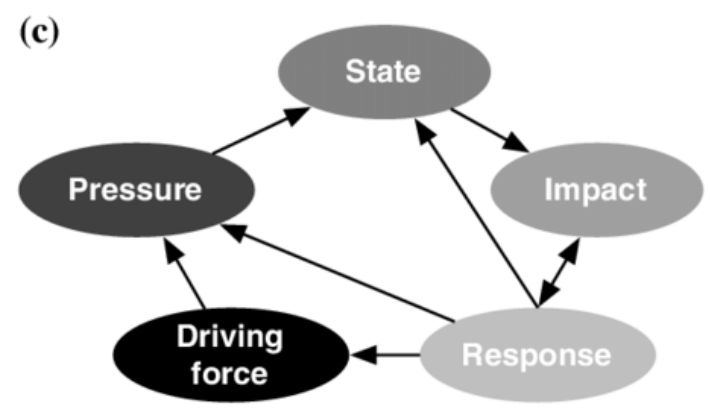

Figure 1: Commonly used conceptual frameworks. a) Pressure-State-Response (PSR), b) Driving force-State-Response (DSR) and c) Driving force-Pressure-State-Impact-Response (DPSIR).

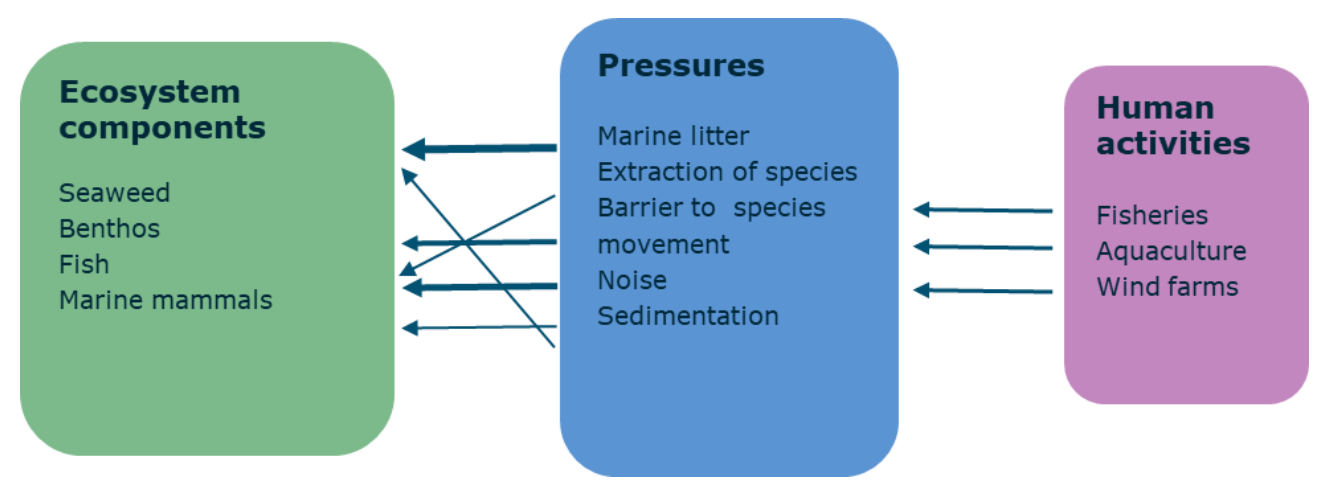

Figure 2: Impact chains linking human activity-pressures-ecosystem components.

\subsubsection{Linkage-based frameworks}

Risk assessments can aid with decision-making when complex networks of interactions between sectors and the ecosystem are involved. However, until recently a link to environmental policy has been lacking. Linkage-based frameworks that adopt the causal-chain concept to infer pressure-state 
relationships (e.g. PSR, DSR and DPSIR) have been developed for marine and terrestrial environments to identify the pathways through which activities impact the ecosystem and support ecosystem-based management (Knights et al., 2015). The EU FP7 ODEMM (Options for Delivering Ecosystem-Based Marine Management) risk assessment framework (Knights et al., 2015) and AQUACROSS (Borgwardt et al., 2019), a project which aims to support EU efforts to protect aquatic biodiversity and ensure the provision of aquatic ecosystem services are examples of such frameworks. In the most extensive framework to date, Driver-Pressure-State combinations for entire ecosystems were developed (Knights et al., 2015, Robinson et al., 2014) and these combinations, which are referred to as "impact chains", were explicitly linked to existing policy objectives, namely the Marine Strategy Framework Directive (MSFD) and its qualitative descriptors of good environmental status (GES) (Piet et al., 2015).

While traditionally the likelihood-consequence approach is used in environmental risk assessments to estimate the risk of rare or unpredictable events such as an oil spill or extreme weather event, exposure-effect analysis is deemed more appropriate for ongoing or current pressures such as fishing or nutrient run-off from agriculture. It is also recognized that multiple sources can have a cumulative effect on the ecosystem components. A systematic procedure for identifying and evaluating the significance of effects from multiple sources/activities is needed to provide an estimate on the overall expected impact to inform management measures. Such a procedure is called a cumulative effect assessment (CEA). A distinction is made between receptor-led CEA and the dominating stressor-led environmental impact assessment (EIA) approach. An example of a receptor-led CEA is the effect of multiple stressors or activities, such as fishing, renewable energy, aquaculture and shipping on marine mammals. An example of a stressor-led EIA approach is for instance the environmental effect of the development of an OWF on the different components of an ecosystem (Piet et al., 2017a).

Linkage based frameworks have been reviewed in Piet et al. (2017). The base of that review is provided by an evaluation of an effective set of principles for practical implementation of marine cumulative effect assessment (CEA) by Judd et al. (2015) and an establishment of why such a variety of CEA approaches (e.g. in terms of the level of detail, stressor- versus receptor led, receptor being the ecosystem component such as marine mammals or fish) exists today and how this is problematic for the global ambition to implement ecosystem approach management of marine waters (Willsteed et al., 2017). Key points from the literature review are:

1. Cumulative effects from multiple sources/activities rather than the effects of a single pressure need to be considered when providing an estimate on the overall expected impact to inform management measures.

2. A key criticism of EIA-led CEA is the stressor-led approach, recognising that receptors experience multiple stressors and accumulate effects over broad temporal and spatial scales, EIAs thus struggle to assess how receptors respond to cumulative effects.

3. While policy-makers, marine managers and researchers have converged on cumulative effects as a key issue to resolve, the varied aims, contexts and expectations of CEAs leads to outputs that are not necessarily fit for purpose for marine management ambitions (Judd et al., 2015).

4. A (cumulative) effect is only considered significant if it has an impact on a relevant ecosystem component. Therefore the framework and approach for a CEA needs to be based on all human activities that may have a potential impact on any relevant (from a policy perspective) ecosystem component at an appropriate spatio-temporal scale.

5. Methodology. Several statistical methods are available for the aggregation of the (semi-) quantified relationships across impact chains, e.g. summation, multiplication, averaging, or by taking the maximum (Piet et al., 2017a). Most ERA methods assume additive effects when analysing cumulative pressures (Stelzenmuller et al., 2015) but other possible interactions (e.g., synergistic interactions) between pressures should also be considered (Piet et al., 2017a).

6. Application of the framework in an integrated management strategy evaluation of a suite of measures, shows that depending on the time horizon (past, present, future), different measures perform best (Piet et al., 2015). 


\subsection{3 iCEA Proof of concept}

Based on the literature review described above, a comprehensive generic linkage framework was developed by Piet et al. (2017a) for an integrated cumulative effect assessment (iCEA) that describes how human activities can impact the ecosystem through pressures to aid decision-making on the exploitation of marine resources. The CEA was developed to be a receptor-led framework, meaning that the ecosystem components, for instance marine mammals are the focal point of the CEA. In addition the CEA was developed to be a fully integrated framework, i.e. involving multiple occurrences of multiple pressures (from single and/or different sources) on multiple receptorshence the use of the phrase iCEA for integrated CEA.

The iCEA, and its key concept Impact Risk, is based around the principles of environmental risk assessment where risk is based on exposure and effect. Exposure is determined by the spatiotemporal overlap between the anthropogenic pressure and the ecosystem component and the severity of the effect is determined by the magnitude of the pressure and the sensitivity of the ecosystem component (Piet et al. 2017a) (Figure 3).

Ecosystem components

Pressures

Activities

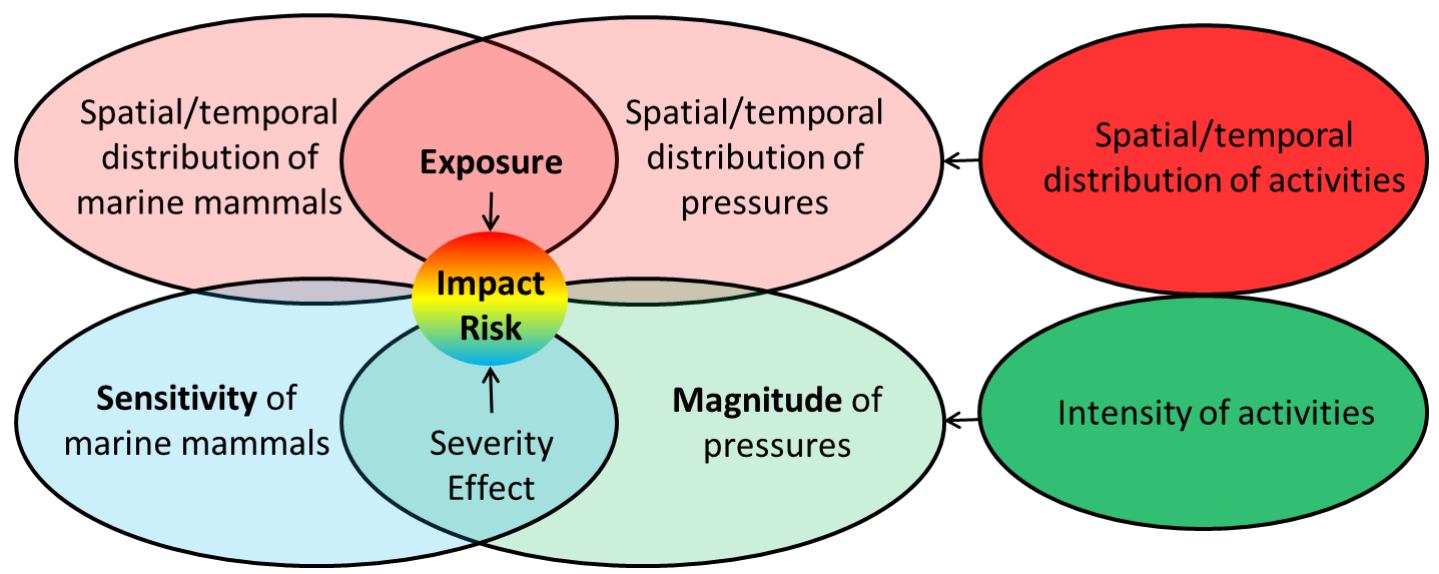

Figure 3: Schematic overview of the iCEA and its key concept Impact Risk taken from Piet et al. (2017a).

The framework adopted by Piet et al. (2017a) is a modular approach structured in four different phases (Table 2). For the purpose of our study phase 1 (conception phase) and phase 2 (execution phase - presence) will be addressed in a conceptual framework on the effects of seaweed cultivation. In addition a case study will be used to estimate the impact risk per impact chain based on expert judgement that addresses phase 3 (Execution - importance) and phase 4 (Evaluation).

Table 2: iCEA framework adopted from Piet et al. (2017a), based on Judd et al. (2015). Modified into an iterative process where the outcome of the $4^{\text {th }}$ phase should feed back into the process at any of the previous phases.

\begin{tabular}{|l|l|l|}
\hline iCEA phase & General & \multicolumn{1}{c|}{ Specifics } \\
\hline Conception & $\begin{array}{l}\text { Purpose and } \\
\text { Scope }\end{array}$ & $\begin{array}{l}\text { How will the iCEA be applied } \\
\text { Identify spatial and temporal scale }\end{array}$ \\
\hline
\end{tabular}




\begin{tabular}{|c|c|c|}
\hline $\begin{array}{l}\text { Execution } \\
\text { (presence) }\end{array}$ & $\begin{array}{l}\text { Identification of } \\
\text { potential effect } \\
\text { of human } \\
\text { activities and } \\
\text { their pressures } \\
\text { on the } \\
\text { ecosystem }\end{array}$ & $\begin{array}{l}\text { Develop linkage framework based on an appropriate } \\
\text { typology of } \\
\text { Human activities, } \\
\text { - Pressures and } \\
\text { Ecosystem components and the possible linkages } \\
\text { between them }\end{array}$ \\
\hline $\begin{array}{l}\text { Execution } \\
\text { (importance) }\end{array}$ & \begin{tabular}{|l|} 
Estimation of the \\
"Impact Risk" \\
per impact chain. \\
This may be \\
based on expert \\
judgement or \\
quantitative \\
information
\end{tabular} & 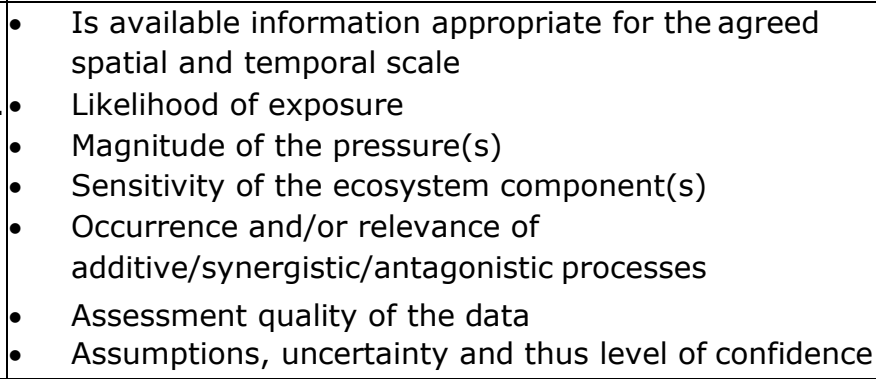 \\
\hline Evaluation & $\begin{array}{l}\text { Consider result } \\
\text { in the broader } \\
\text { context and to } \\
\text { inform the next } \\
\text { iteration cycle }\end{array}$ & 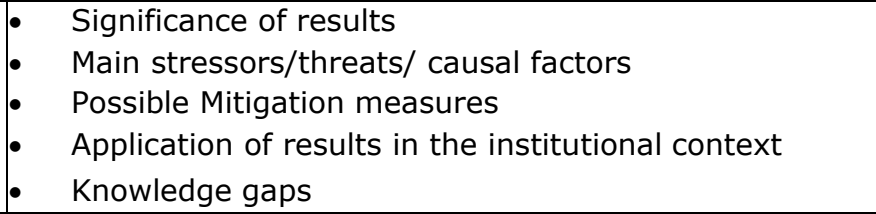 \\
\hline
\end{tabular}

\subsection{Towards a Framework development and EIA approach for aquaculture}

A risk assessment framework is developed that describes how seaweed farming can impact the ecosystem through pressures. The application of the methodology for sea mammals in the (Dutch) North Sea (Piet et al., 2017a), that was based on the risk assessment framework ODEMM and AQUACROSS is used as a base for this framework (Borgwardt et al., 2019, Knights et al., 2015).

\section{Conception phase}

The aim is to develop a conceptual framework that will map ecological impacts in and around seaweed farms. This framework should be applicable to a wide range of cultivation methods and locations in offshore areas, the Dutch coastal zone and Delta waters. It should be designed in such a way that cumulative effects of other sources and activities can also be incorporated at a later stage.

\section{Execution phase (presence) - development of impact chains}

The second step in developing the assessment framework for seaweed farming is the creation of a sector-pressure-ecological component matrix (Figure 4). Each cell in the matrix describes the potential for impact on an ecological component from a sector, wherein a pressure is the mechanism through which an impact occurs. This linear interaction between a sector, pressure, and ecological component is referred to as an impact chain (Knights et al., 2015). In this study the focus is on pressures from seaweed aquaculture. However, knowing that the cumulative effect of pressures from multiple sources need to be considered for providing an estimate on the overall expected impact to inform management measures, a flexible approach should be taken that is applicable in various situations. The option to expand and combine this framework is therefore essential.

\section{Execution phase (importance) - estimation of the impact risk} A case study evaluating ecosystem interactions of seaweed aquaculture will be used to estimate the impact risk per impact chain by means of a quantitative assessment based on expert judgement.

\section{Evaluation phase}

Discussion of the outcome including prioritization of high risk impact chains and main stressors, knowledge gaps and suitability for application. 
Figure 4: Matrix representing the impact chains between ecological components, pressures and sector. 


\section{Framework for evaluation of Seaweed farming-Ecosystem Interactions}

In the following chapter a DPSIR (driver, pressure, state, impact, response) approach based on Piet et al. (2019) is followed to describe potential seaweed farming related impacts that apply to the different ecosystem components. The current focus of EIA's is on ecosystem impacts and not services. Ecosystem services, or positive effects from seaweed farming activities have the potential to be incorporated in future EIA's to provide a more comprehensive and balanced estimate of the risks involved with seaweed cultivation. The policy and environmental legislation regarding seaweed cultivation in Europe include a common set of farming principles such as: siting that minimizes damage to sensitive environments; seed sources that maintain the genetic diversity of wild stock; a ban on cultivation of non-native species; biosecurity measures to control the spread of diseases, parasites and non-native species; no fertilization and a well maintained infrastructure (Campbell et al., 2019).

\subsection{Ecological pressures introduced by seaweed farming}

\subsubsection{Activities related to seaweed farming (drivers)}

The definition of large-scale is adopted from Campbell et al. (2019) where large-scale refers to more than fifty $200 \mathrm{~m}$ lines. Large-scale cultivation of seaweed is generally performed on long-line systems, similar to the system used in mussel aquaculture (Figure 4). This is a relatively simple structure in which the seaweed is suspended on vertical lines or droppers from the main horizontal longline which is kept in place with anchors and buoys. The use of droppers, vertical lines with seedlings attached, is commonly used as an inoculation system. Depending on the size of the seaweed farm, several longlines can be arranged in a grid, creating a 3D structure, in which the separate longlines are connected with ropes (Figure 5). Longlines are generally orientated perpendicular to the main current direction. A perpendicular orientation gives a higher certainty that enough nutrients are available for all seaweeds on the rope. However, this also depends on the size of the seaweed farm.

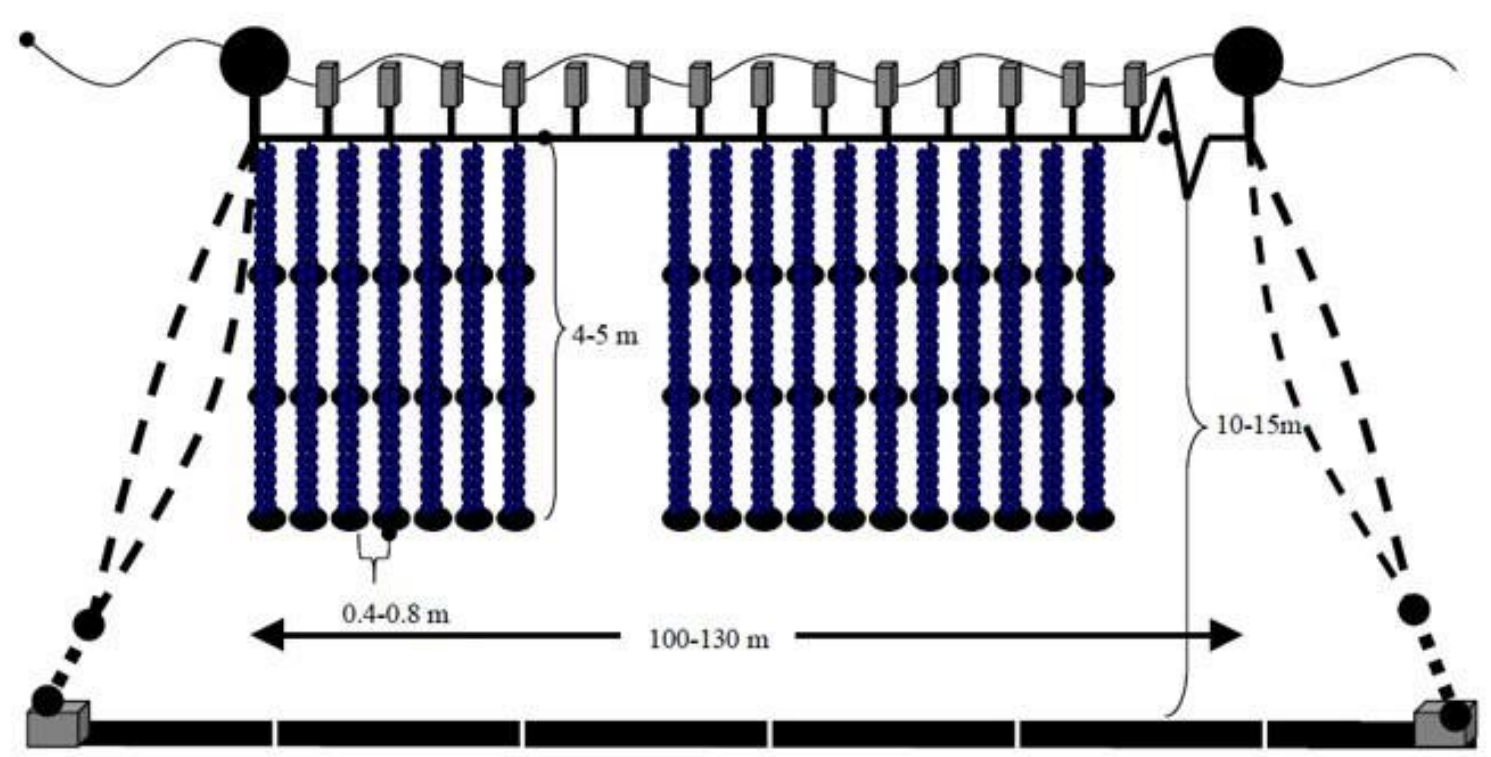


Figure 4: Side view of mussel longline showing attached dropper lines, floats and anchor points.

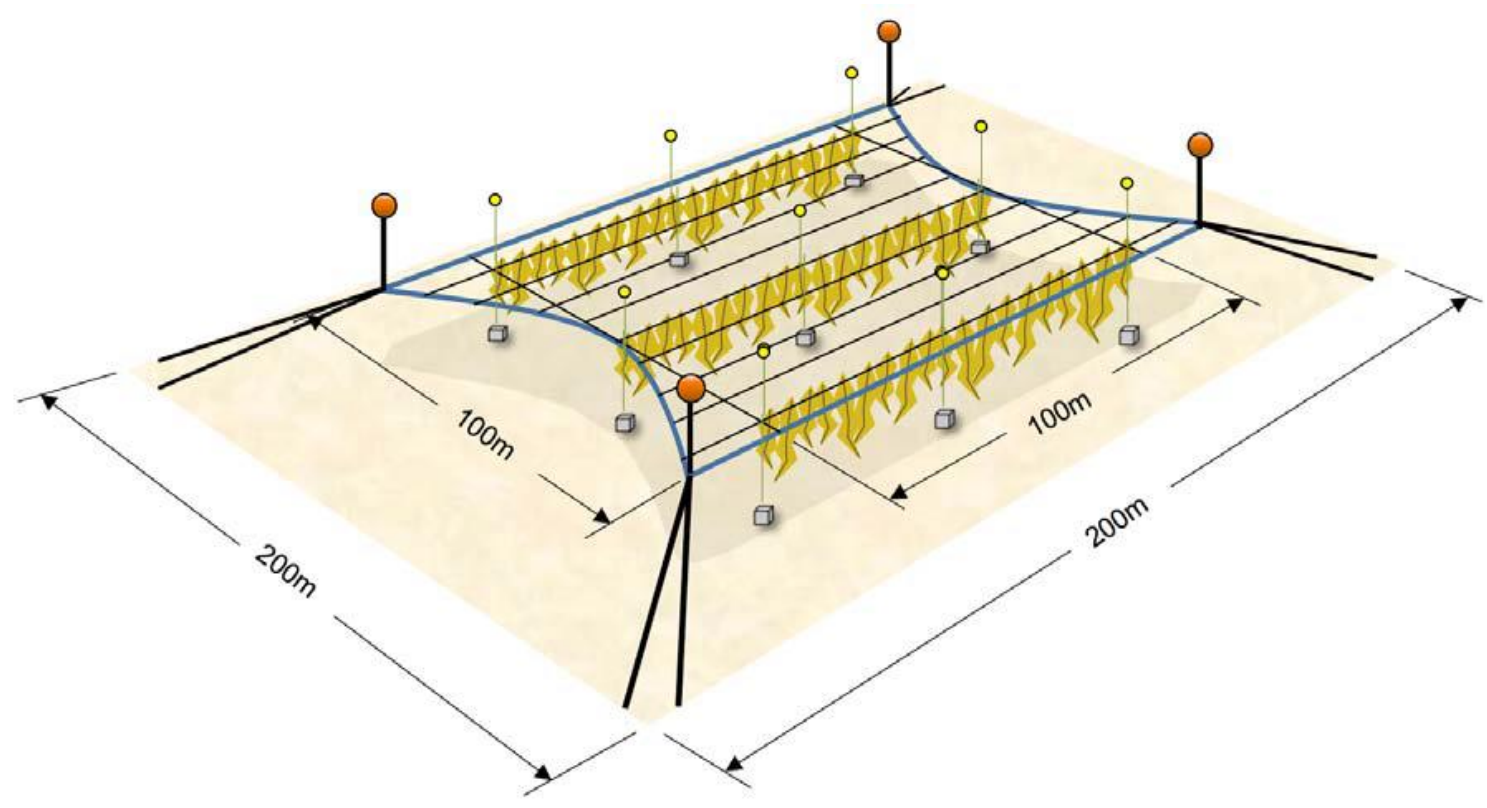

Figure 5: 3-dimensional longline support structure for kelp farming (Goudey, 2015).

The different stages for seaweed cultivation systems are: installation, operation (further divided in sub-stages: inoculation, cultivation maintenance and harvesting) and decommissioning. The different stages are bound to specific 'time-slots' depending on the seaweed species that is cultivated. For winter species such as sugar kelp deployment of the system should not take place too early in summer to avoid excessive growth or fouling on the system, but also not too late in order to finish deployment before the storm season commences. Inoculation occurs mid-October to November. However, this is also highly dependent on the water temperature that has to be low enough. During cultivation monitoring and maintenance is needed approx. once a month. Harvesting takes place during a short period of time and needs to be timed before fouling occurs. The (sub)activities involved with each stage are described in Table 3. The size of the seaweed farm, where it is located (latitude), in what type of system (inshore versus offshore) and the seaweed species involved all influence the impact of the activities. For instance the length and timing of the cultivation season varies depending on the seaweed species involved and the location (latitude) or system (inshore versus off shore).Generally speaking, seaweed species can be divided in those that mainly grow in summer, such as Ulva lactuca (a.k.a. sea lettuce) and those that grow during the winter season such as kelp. The growing season of most kelp species (for example: Saccharina latissima and Laminaria digitata) is approx. 5 months during winter and early spring (Bikker et al., 2013), with highest growth from April to June. Sub-activities such as shipping may differ between the different stages of seaweed farming. For instance shipping during installation likely involves larger boats specifically equipped to deploy longlines, buoys and mooring as opposed to shipping during cultivation. Harvesting can be done mechanically or manually. Manual harvesting often occurs in China, Indonesia, and the Philippines using small boats and cutting kelp from the longline. Multiple types of mechanical harvesting exist, a common machine known as a "scoubidou" uses a sickle-style hook to harvest the mature portion of 
the algae Timing of harvesting depends on the cultivated seaweed species. For winter species such as kelp harvest occurs in spring to prevent fouling of the kelp itself.

Table 3: Description of the different stages of seaweed farming and the activities involved with each stage.

\begin{tabular}{|l|l|l|}
\hline $\begin{array}{l}\text { Stages of seaweed } \\
\text { farming }\end{array}$ & Sub-stage & Sub-activities \\
\hline Installation & & $\begin{array}{l}\text { Deployment cultivation systems, buoys and mooring (trampling, } \\
\text { interaction with seafloor) } \\
\text { Shipping } \\
\text { Manual labour }\end{array}$ \\
\hline Operation & Inoculation & $\begin{array}{l}\text { Deployment of the inoculation system } \\
\text { Shipping } \\
\text { Manual labour }\end{array}$ \\
\cline { 2 - 3 } & Cultivation & $\begin{array}{l}\text { Early growth phase } \\
\text { Final growth phase } \\
\text { Maintenance/manual labour } \\
\text { Shipping } \\
\text { Monitoring }\end{array}$ \\
\cline { 2 - 4 } & Harvesting & $\begin{array}{l}\text { Mechanical or manual harvesting } \\
\text { Shipping } \\
\text { Manual labour }\end{array}$ \\
\hline Decommissioning & $\begin{array}{l}\text { Retrieval of cultivation systems, buoys and mooring (trampling, interaction } \\
\text { with seafloor) } \\
\text { Shipping } \\
\text { Manual labour }\end{array}$ \\
\hline & & \\
\hline
\end{tabular}

\subsubsection{Different properties and activities of offshore versus inshore seaweed farming}

Besides the cultivated seaweed species and the size of the seaweed farm, the activities involved with seaweed farming depend on the location or ecosystem (offshore versus inshore) the cultivation takes place in. For instance, various types of mechanical harvesting techniques are used, depending on the type of seaweed that is grown, how this seaweed needs to be harvested and whether it is grown inshore or offshore. In addition offshore seaweed farms are preferably visited less frequently due to the remote location of these farms, resulting in less frequent disturbance from shipping.

Offshore seaweed farms are generally exposed to more extreme conditions, including strong currents, swells and storms, and require a more robust cultivation system, whereas inshore farms are aligned in more protected conditions. Basic properties necessary for seaweed growth, such as light and nutrient availability will also vary between these systems (for example in the North sea versus the Eastern Scheldt) and will partly determine what species can be grown successfully. 
Table 4: Different properties and activities involved with offshore versus inshore seaweed farms

\begin{tabular}{|c|c|c|}
\hline Differences between systems & Offshore & Inshore \\
\hline Basic properties/environmental factors & $\begin{array}{l}\text { Stronger currents and swells, } \\
\text { more exposure to storms, higher } \\
\text { flux, more light availability }\end{array}$ & $\begin{array}{l}\text { Often more sheltered, higher in } \\
\text { nutrients/exposure to land-based } \\
\text { activities (run-off from agriculture) }\end{array}$ \\
\hline Cultivation system & $\begin{array}{l}\text { More robust, needs to withstand } \\
\text { strong currents, swells, often } \\
\text { larger }\end{array}$ & Often smaller sized farms \\
\hline Cultivation period/timing & $\begin{array}{l}\text { Weather/storm season is more } \\
\text { important }\end{array}$ & $\begin{array}{l}\text { Also possible during storm season due } \\
\text { to less exposed site }\end{array}$ \\
\hline Logistics & Visited less frequently & $\begin{array}{l}\text { Easier to access for maintenance and } \\
\text { harvesting }\end{array}$ \\
\hline Harvesting & $\begin{array}{l}\text { Often larger farms, need for } \\
\text { mechanical harvesting }\end{array}$ & $\begin{array}{l}\text { Harvesting can be done either } \\
\text { mechanically or manually (takes longer } \\
\text { but often used in developing countries) }\end{array}$ \\
\hline
\end{tabular}

\subsubsection{Processes that potentially interfere with ecosystem functioning (pressures)}

Growing seaweed in an offshore or inshore setting results in a number of interactions between seaweed farming and the ecosystem. The various activities involved exert pressures on the different ecosystem components. These pressures can result in positive services but can also have negative effects (Jansen and Tonk, 2019). Ecosystem service functions of seaweed are, for example, to alleviate the high nutrient levels in the North Sea and to increase biodiversity by providing additional habitat. But when seaweed production is too high, competition for nutrients may take place with naturally occurring seaweed, seagrass and phytoplankton with an effect on diversity. When competition for nutrients impacts phytoplankton communities this may also have effects on organisms higher up the food chain. As a result the ecosystem interaction can have a negative effect on the environment. The cultivation system itself, which consists of a combination of lines and buoys anchored to the seafloor can also have an effect (Figure 5), such as attracting biodiversity. However, it may also act as a physical barrier to species movement. The mechanisms through which an activity has an effect on any part of the ecosystem, such as the artificialisation of habitat or barrier to species movement, are called pressures. The different types of pressures that stem from the activities involved with seaweed farming can be arranged in three themes adopted from the Marine Strategy Framework Directive 2017 (MSFD); biological (such as drop-off or organic deposition of seaweed), physical (such as absorption of light by seaweed) and a third theme named substances (e.g. synthetic, non-synthetic and radionuclides), litter (solid waste matter, including micro-sized litter) and energy (e.g. sound, light, heat and electromagnetic). An overview of the different pressures in each of these themes is presented in Table 5. Note that only the pressures that apply to the scale of water phase until harvesting have been taken into account. For instance high quantities of heavy metals in toxic concentrations that pose a negative effect when seaweed is cultivated for human consumption or animal feed are not taking into account (Hasselstrom et al., 2018). On the other hand, the risk of accumulation of heavy metals such as inorganic arsenic (As), cadmium (Cd) and iodine (I) in seaweed by wild fauna during the cultivation stage is taken into account. 


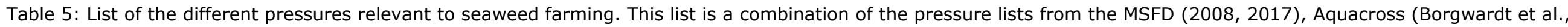
2019) and additional pressures relevant to the seaweed farming framework (SWF).

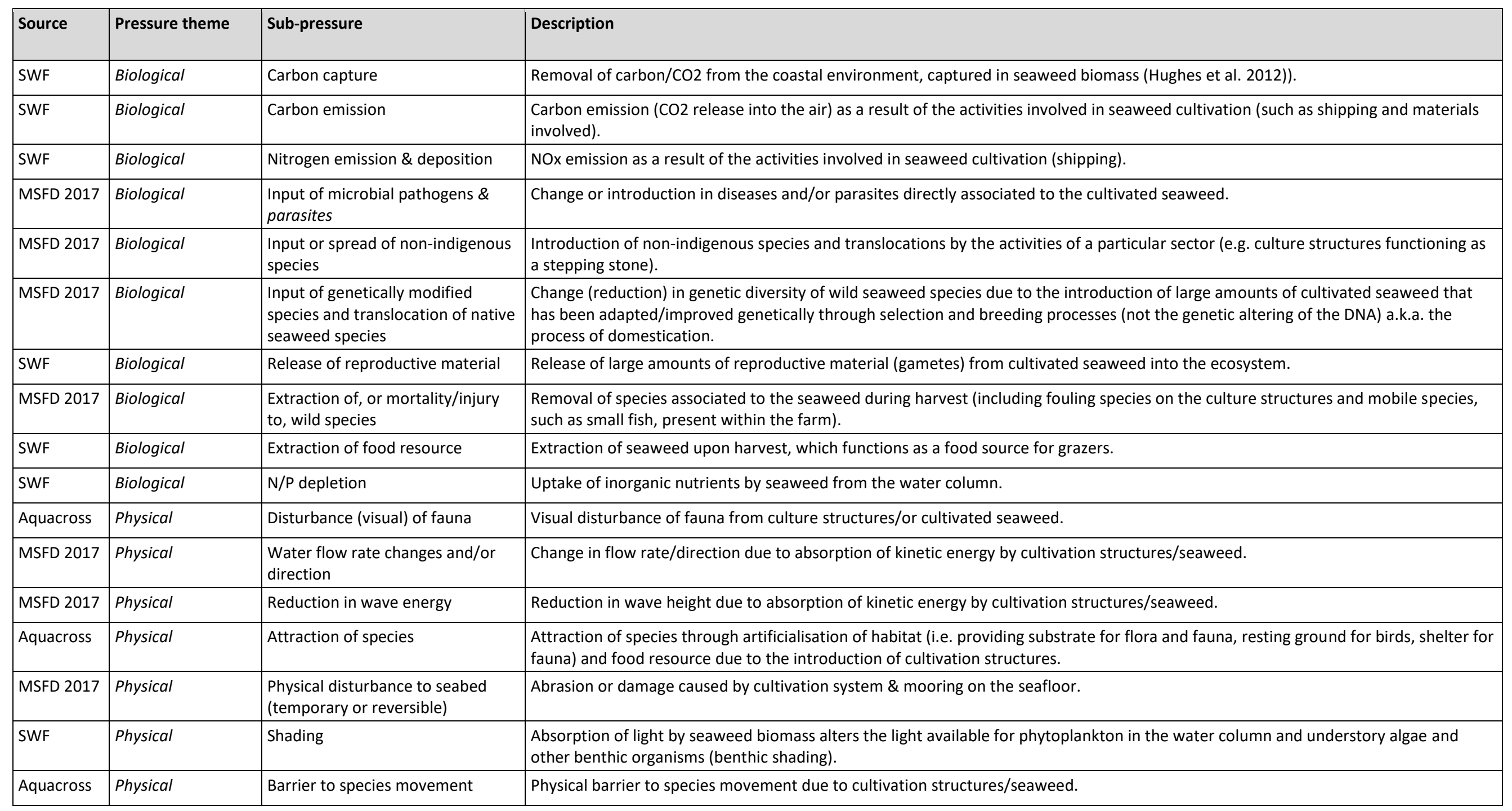




\begin{tabular}{|c|c|c|c|}
\hline Aquacross & Physical & Death or injury by collision & Death or injury of marine fauna due to impact with moving parts of a human activity, e.g. marine mammals with ships. \\
\hline SWF & Physical & Entanglement & Entanglement of large fauna in the cultivation system. \\
\hline MSFD 2008 & Physical & Changes in siltation & Sedimentation due to current changes caused by cultivated seaweed. \\
\hline MSFD 2017 & $\begin{array}{l}\text { Substances, litter } \\
\text { and energy }\end{array}$ & Input of organic matter & Organic enrichment and any subsequent deoxygenation, e.g. from drop-off of seaweed biomass. \\
\hline MSFD 2008 & $\begin{array}{l}\text { Substances, litter } \\
\text { and energy }\end{array}$ & $\begin{array}{l}\text { Introduction of non-synthetic } \\
\text { substances and compounds }\end{array}$ & $\begin{array}{l}\text { Introduction of non-synthetic substances and compounds: e.g. heavy metals, hydrocarbons, resulting, for example, from pollution by } \\
\text { ships and oil, gas and mineral exploration and exploitation, atmospheric deposition, riverine inputs. }\end{array}$ \\
\hline MSFD 2008 & $\begin{array}{l}\text { Substances, litter } \\
\text { and energy }\end{array}$ & $\begin{array}{l}\text { Introduction of synthetic } \\
\text { compounds }\end{array}$ & $\begin{array}{l}\text { Introduction of synthetic compounds: e.g. priority substances under Directive } 2000 / 60 / E C \text { which are relevant for the marine } \\
\text { environment such as pesticides, antifoulants and pharmaceuticals. }\end{array}$ \\
\hline SWF & $\begin{array}{l}\text { Substances, litter } \\
\text { and energy }\end{array}$ & $\begin{array}{l}\text { Absorption of trace and heavy } \\
\text { metals }\end{array}$ & $\begin{array}{l}\text { 1. Depletion of heavy metals and } 2 \text {. the risk of accumulation of heavy metals such as inorganic arsenic (As), cadmium (Cd) and iodine (I) } \\
\text { in seaweed that is consumed by animals in the ecosystem. }\end{array}$ \\
\hline MSFD 2017 & $\begin{array}{l}\text { Substances, litter } \\
\text { and energy }\end{array}$ & $\begin{array}{l}\text { Input of litter (solid waste matter, } \\
\text { including micro-sized litter) }\end{array}$ & $\begin{array}{l}\text { Farming material such as lines and buoys are comprised of synthetic materials (e.g. polypropylene) and may lead to pollution (in the } \\
\text { form of debris or litter due to lost components due to storm damage or general wear and tear adding micro-plastics, metal, glass, } \\
\text { rubber, wood and cloth to the environment). }\end{array}$ \\
\hline MSFD 2017 & $\begin{array}{l}\text { Substances, litter } \\
\text { and energy }\end{array}$ & $\begin{array}{l}\text { Input of anthropogenic sound } \\
\text { (impulsive, continuous) }\end{array}$ & Underwater and other noise from shipping or machines required for installation or operation. \\
\hline MSFD 2017 & $\begin{array}{l}\text { Substances, litter } \\
\text { and energy }\end{array}$ & Input of light & Input of light from buoys or boats. \\
\hline
\end{tabular}




\subsection{Ecological response to seaweed farming}

\subsubsection{Description and sensitivity of ecosystem components under pressure}

The marine ecosystems in which seaweed aquaculture takes place in the North sea area comprise of complexes of organisms living in the marine environment and can be divided in different categories or components. These components consist of groups of fauna, flora or habitat types that are created to assist in gaining a coherent and integrated assessment across ecosystems. The different components of the ecosystem that need to be considered when evaluating ecosystem interactions of seaweed aquaculture are described in Table 6.

Table 6: Overview of the different ecosystem components that need to be considered when assessing ecosystem interactions of seaweed farming. This table is taken from Tonk and Jansen (2019) and adjusted.

\begin{tabular}{|c|c|c|}
\hline Ecological component & Subcomponent & Description \\
\hline Plankton & & $\begin{array}{l}\text { Plankton is a diverse group of floating small and microscopic } \\
\text { organisms (plant and animal) in water that cannot swim against the } \\
\text { flow. }\end{array}$ \\
\hline $\begin{array}{l}\text { Seaweed \& } \\
\text { seagrass }\end{array}$ & & $\begin{array}{l}\text { Other naturally occurring or introduced seaweed (macro-algae) and } \\
\text { seagrass (submerged plants in marine environments). }\end{array}$ \\
\hline $\begin{array}{l}\text { Epiphytes \& } \\
\text { epibionts }\end{array}$ & & $\begin{array}{l}\text { Organisms that live on seaweed in a non-parasitic manner (without } \\
\text { extracting nutrients). }\end{array}$ \\
\hline \multirow[t]{2}{*}{ Benthos or macrofauna } & On-bottom & $\begin{array}{l}\text { Small benthic animals such as shellfish, tubeworms, crabs and } \\
\text { shrimps that live on the sediment beneath the farming structures. }\end{array}$ \\
\hline & Off-bottom & $\begin{array}{l}\text { Small animals (mussels, shrimps, tunicates or sea squirts, juvenile fish } \\
\text { etc.) that live on the seaweed and the farming construction. }\end{array}$ \\
\hline \multirow[t]{2}{*}{ Fish } & Adult & Adult pelagic and demersal fish. \\
\hline & Juvenile & Juvenile fish \\
\hline \multirow[t]{3}{*}{ Avial animals } & Seabirds & $\begin{array}{l}\text { Birds that live near the sea and get their food from the marine } \\
\text { environment. }\end{array}$ \\
\hline & Migratory birds & Birds that travel (seasonally) to a different place. \\
\hline & Bats & $\begin{array}{l}\text { Mainly nocturnal mammals capable of sustained flight. Bats can be } \\
\text { affected in a similar way as birds. }\end{array}$ \\
\hline $\begin{array}{l}\text { Marine } \\
\text { mammals }\end{array}$ & & Grey seals, sea lions, dolphins, harbour porpoises and minke whales. \\
\hline \multirow[t]{4}{*}{ Predominant habitat } & Hard substrate & Sublittoral rock, shell and artificial substrate (anchor points). \\
\hline & Soft sediment & Sublittoral sand or mud. \\
\hline & Water column & $\begin{array}{l}\text { With a focus on water quality of pelagic or inshore water of the } \\
\text { euphotic zone (the layer closer to the surface that receives enough } \\
\text { light for photosynthesis to occur). }\end{array}$ \\
\hline & Terrestrial & Coastal and more land inward. \\
\hline
\end{tabular}


Some of the potential responses of the different ecosystem components to pressures involved with seaweed farming are described below.

\subsubsection{Plankton}

Plankton is affected by seaweed farming in several ways. When too much seaweed is cultivated the available nutrient pool may become depleted. Potentially not leaving enough nutrients for phytoplankton (micro-algae) to grow. This may affect the carrying capacity of the ecosystem, with possible effects on organisms higher up in the food chain. Little is known about the carrying capacity in relation to seaweed cultivation in the North Sea. A modelling study on the potential production of seaweed in North Sea coastal water does not indicate large-scale changes in biogeochemistry and plankton dynamics at simulated seaweed cultivation sites (van der Molen et al., 2018). This, however, depends on factors such as the size of seaweed cultivation and the cultivated species. In situ measurement are needed to get more information on depletion of nutrients by cultivated seaweed. A quick scan of available nutrients indicate that realistic upscaling of seaweed aquaculture in offshore windfarms in the North Sea is likely in the order of magnitude of several hundred $\mathrm{km}^{2}$ for future seaweed production based on carrying capacity, expressed as nutrient extraction (van Duren et al., 2019). On the other hand the uptake of nutrients from the water by seaweed can also have a positive effect on the water quality, the visibility in the water column and the plankton diversity (Jiang et al., 2012). Seaweed also promotes sedimentation and in this way influences the light availability in the water column. Other potential responses to seaweed farming are the production of substances by seaweed that can affect the growth and development of other organisms (allelopathy). This is how seaweed protects itself against fouling. Besides repelling organisms these substances can also attract other plankton species and thus increase biodiversity (Chai et al., 2018). Zooplankton (the animal component of plankton) uses the protection and food supplied by seaweed (Hammer, 1981).

\subsubsection{Seaweed and seagrass}

The cultivation system can serve as a substrate for other algae and thus increase the diversity but it can also provide opportunities for invasive species to settle on. Invasive species are organisms that are not native to that specific location and have established themselves through anthropogenic activities. This can have a series of negative consequences such as loss of biodiversity (potentially including the disappearance of indigenous species), introduction of new diseases and economic damage. Competition for nutrients and space of cultivated seaweed with naturally occurring seaweed/seagrass is less applicable in the North Sea, but plays a larger role in locations where seagrass or kelp forests are at the base of the ecosystem. Whether competition can actually take place also depends on the size of the seaweed farm. Moreover, seagrass fields and most other seaweeds grow on the seafloor, while farmed seaweed grows in cultivation systems suspended in the water column. However competition for light due to shading by cultivated seaweed may also effect the local benthic algae or seagrass population by changing the amount of available light.

\subsubsection{Epiphytes}

Epiphytes differ from parasites in that epiphytes grow on other plants for physical support and do not necessarily negatively affect the host. An epiphytic organism that is not a plant is called an epibiont. Epibionts or epiphytes can occur on seaweed and increase biodiversity with their presence. However they can also cause shading; when grazed on the seaweed grows faster (Kamermans et al., 2002). Undesirable epiphytes or epibionts (other harmful algae species, bacteria, viruses and fungi) can also be introduced which may result in a decrease in produced seaweed biomass. To counteract this, seaweed produces allelochemical substances that have a negative effect on the growth of epiphytes or epibionts. 
On-bottom macrofauna: Anchor points can have a direct effect on the macrofauna of the North Sea that mainly consists of soft sediment. Small animals such as shellfish, tubeworms, crabs and shrimps that live on and under these constructions (McKindsey et al., 2011) may benefit from the newly created habitat. On the other hand, some benthic animals can be crushed under anchor points (to put this in perspective, relatively few anchor points are used and they often remain for years). Small pieces of seaweed can serve as food for filter feeders and grazers (Wood et al., 2017) but sedimentation of loose seaweed may also affect the organic composition of the sediment with possible effect on the diversity of the benthic community (Wood et al., 2017). Whether this effect is positive or negative depends on the scale of seaweed production, the location and the current state of the benthic community. Shading by seaweed may also influence the local benthic community by changing the amount of available light. Macrofauna such as bivalves and crabs are able to ingest microplastics such as fibres and pellets from wear and tear of farming materials (Waite et al., 2018). Currently, ecological risks from microplastics are considered rare, although there are some locations with high concentrations of pollution where risks already exist (SAPEA, 2019).

Off-bottom macrofauna: Seaweed is usually cultivated in suspended or hanging culture systems. The seaweed and the farming construction create habitat, substrate and offer protection against larger predators and birds to small animals that live on and amongst the seaweed and farming construction (Ingle et al., 2018). The seaweed and the cultivation structure also function as a nursery for small fish and other juvenile animals and thereby increase biodiversity (Ingle et al., 2018). On a single kelp in the Norwegian North Sea 40 small animal species (macroinvertebrates) and 8000 individuals were detected (Christie et al., 2003). Similar to shipwrecks and oil platforms, seaweed cultivation systems offer substrate for many organisms and can thus serve as an intermediate port or "stepping stone" for invasive species. On the other hand, some native species such as the blue mussel (Mytilus edulis) depend on the stepping stone effect created by these structures for their distribution (Coolen, 2017). In the North Sea thousands of artificial hard substrates exist in the form of wrecks, oil and gas platforms and wind farms. It is therefore plausible that most of these constructions are connected directly or indirectly by water currents, through which offshore energy installations already function as a large reef network (Coolen, 2017).

\subsubsection{Fish}

Floating structures in the open sea are known to attract both pelagic and demersal fish (Kingsford, 1993, Morrisey et al., 2006). Numbers of fish attracted by seaweed production are still lacking (Tonk and Jansen, 2019). However, a positive correlation is demonstrated between seaweed production and the amount of herbivorous fish caught in Southeast Asian countries (Hehre and Meeuwig, 2016). In addition a positive correlation has been found between Ulva and fish species such as pipefish, eelpout, shorthorn sculpin and rock gunnel or butterfish. Other fish species show no correlation or a negative correlation with Ulva (such as herring, goby and whiting) (Jak et al., 2020). Fish and fish larvae are able to ingest debris such as plastic or microplastic with potential negative effects. The frequency of occurrence and the average number of plastics in North Sea fish was found to be generally low $(1.8 \%$ and 0.022 pieces per organism respectively), with no correlation with distance to the coast (Kühn et al., 2020). 
Birds are attracted to seaweeds worldwide. It is therefore plausible that seabird species take advantage of the high amount of prey in and around seaweed farms (Wood et al., 2017). Buoys of cultivation systems may also serve as a resting place for seabirds and migratory birds (Roycroft et al. 2004). However, the combination of wind parks and seaweed farms can pose dangers to birds by means of the impact of wind turbines and rotors that birds may collide with. Other adverse effects in this category are more focused on inland waters or coastal locations where change of the seabed can affect the food supply for shorebirds. Bats, although mammals and not birds, behave similar to birds and also forage over the sea and therefore are at risk of collision with rotors of wind turbines (Lagerveld et al., 2015). Seabirds are also known to ingest plastic with negative effects (Lavers et al., 2019).

\subsubsection{Marine mammals}

Seaweed cultivation systems may create barriers in the natural habitat of marine mammals and thereby displace certain animals that prefer the open water to hunt (Callier et al., 2017) or influence their regular migration pattern. Grey seals regularly cross the North Sea and from the east coast of the UK, even seal pups are known to make this crossing regularly (Brasseur et al., 2015).

Entanglement in lines, although unlikely due to the simple set-up of the cultivation structures, should also be considered a well as ingestion of debris such as plastics or microplastics (Nelms et al., 2019). In addition seals can use artificial structures such as lines and buoys as a resting place. Studies directly related to seaweed farms are not known (Tonk and Jansen, 2019), but it is plausible that mammals are attracted by the high numbers of prey in seaweed farms, similar to sea otters in kelp forests (Estes and Duggins, 1995) or seals that systematically forage around offshore wind farms (Russell et al., 2014). The effect of additional shipping/harvesting activities on marine mammals should also be considered.

\section{Predominant habitat}

Predominant habitat can be divided in hard substrate (including sublittoral rock, shells or artificial substrate) soft sediment such as sand or mud and the water column which can be pelagic or inshore and is situated in the euphotic zone (the layer closer to the surface that receives enough light for photosynthesis to occur) or below in deeper waters. In the ocean this zone can be up to $200 \mathrm{~m}$ deep. The habitat can be affected by pressures such as organic deposition, littering, sediment disturbance or introduction of farming structures and anchoring.

\subsubsection{Seaweed interaction framework - impact chains}

The direct interactions between activities and pressures on the one hand and between pressures and ecosystem components on the other hand combined provide the basis of the various impact chains involved with seaweed farming (Annex 1 and 2). A total of 631 impact chains were established based on expert judgement. A complete overview of the different impact chains is provided in Figure 6. These impact chains are used in the next step to assess and prioritize impact risks.

Points of attention:

1) Only direct effects are taken into account.

2) Double or comparable pressures leads to an overestimation of impact risk.

3) Too much detail in the activity sub-stages leads to an overestimation of impact risk.

4) Level of detail needs to be equal between activity sub-stages to avoid a skewed outcome.

5) Impact risks are assessed at the scale of the water phase (impact risk for human consumption is not taken into account).

6) When assessing the impact of the various activities that are performed best practise is assumed.

7) Cumulative and synergistic effects of anthropogenic activities not linked to seaweed cultivation are not taken into account at this stage. 


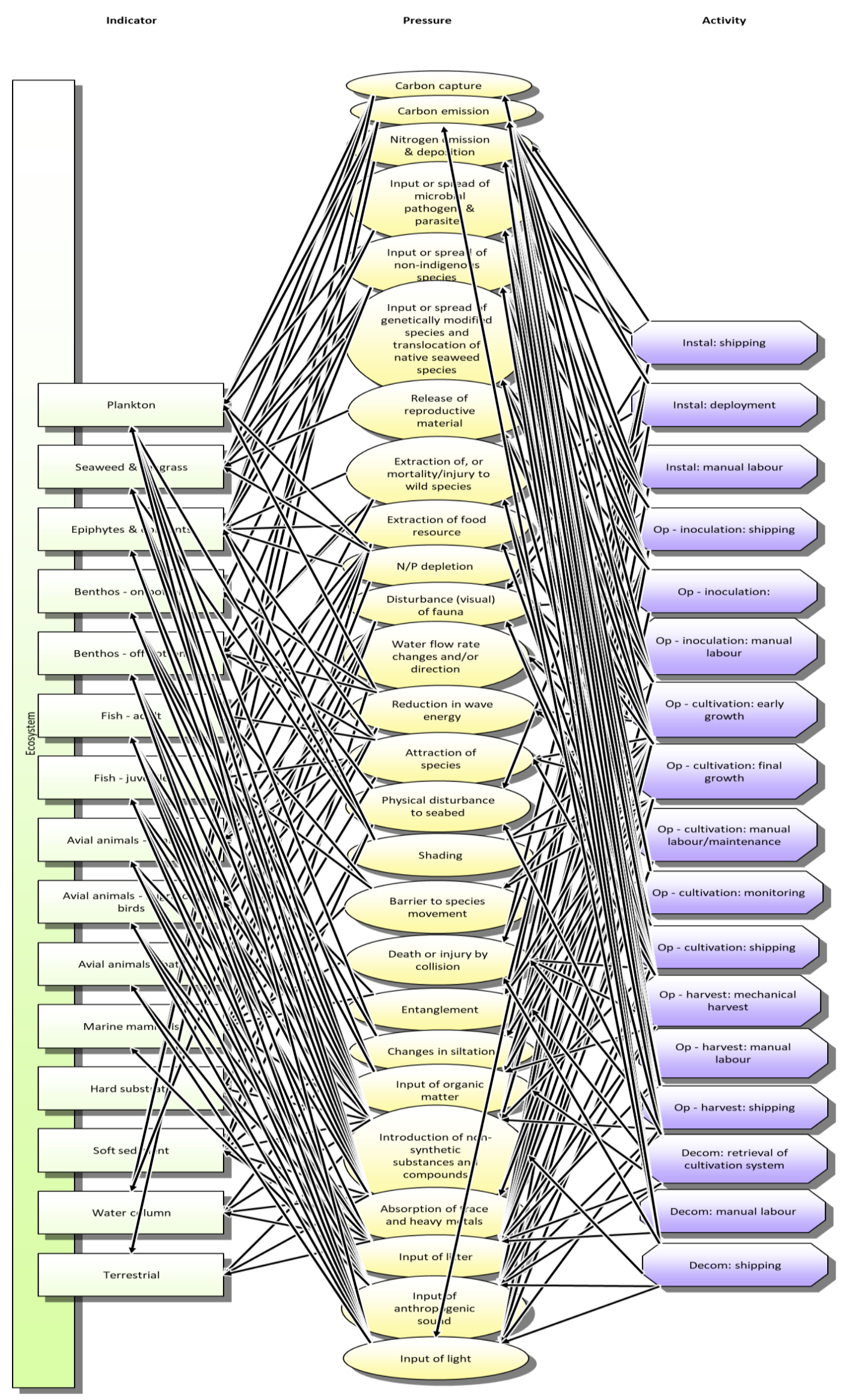

Figure 6: Framework representing the interactions (impact chains) between ecosystem components, pressures and sub-activities per cultivation stage (installation [Instal], operation [Op],

decommissioning [Decom]. The interactions (or impact chains) are indicated in arrows. This figure has been constructed using the WMR scoping tool (de Vries et al., 2013). 


\subsubsection{Impact risk of the pressures involved with seaweed farming}

The effect of these pressures or "impact risk" involved needs to be estimated per impact chain (activity-pressures-ecosystem component). The impact risk is defined as the contribution of an impact chain to the risk a specific ecosystem component is impacted. In other words the risk an ecosystem component is impacted depends on the scoring of the activity, the pressure and the ecosystem component itself. The impact risk may be based on expert judgement or quantitative information. For the SWF in assessment based on expert judgement is applied using six criteria (spatial extent, dispersal, frequency, persistence, severity and resilience) (Table 7) adopted from the risk assessments used in AQUACROSS, a project which aims to support EU efforts to protect aquatic biodiversity and ensure the provision of aquatic ecosystem services (Borgwardt et al., 2019) and ODEMM, a project which aims to develop a set of options for delivering ecosystem-based marine management (Knights et al., 2015).

Table 7: Criteria used in the SWF, semi-quantitative assessment are adopted from AQUACROSS (Borgwardt et al., 2019) and ODEMM (Knights et al., 2015).

$\begin{array}{ll}\text { Criteria Description } & \text { Criteria } \\ & \text { source }\end{array}$

\begin{tabular}{|l|l|l|}
\hline Spatial extent & Spatial overlap of each activity-pressure combination with an ecosystem component & AQUACROSS \\
\hline Dispersal & Effect of the dispersal of the pressure on realised area of spatial overlap & AQUACROSS \\
\hline Frequency & Temporal overlap of each activity-pressure combination with an ecosystem component & AQUACROSS \\
\hline Persistence & Length of time that is needed that a pressure disappears after activity stops & AQUACROSS \\
\hline Severity & Likely sensitivity of an ecosystem component to a pressure where there is an interaction & AQUACROSS \\
\hline Resilience & $\begin{array}{l}\text { The generic resilience (recovery time) of the ecological characteristic is assessed based } \\
\text { on its current status in the regional sea and categorised based on recovery times }\end{array}$ & ODEMM \\
\hline
\end{tabular}

\subsubsection{Spatial extent}

The spatial extent is defined as the spatial overlap of each activity-pressure combination with an ecosystem component. The overlap can be small and restricted to the size of the seaweed farm (for instance the introduction of anchors can locally effect benthos by crushing them upon deployment), or the activity may be local in the vicinity of the seaweed farm (for example shipping). The pressure can also extend further in which case it often depends on the system the seaweed farm is operated in (inshore versus offshore). Table 8 shows the spatial extent categories as applied in AQUACROSS. For the SWF we've applied relevant numbers on the overlap of each sub-activity and ecosystem component to assess spatial extent. Using relevant numbers instead of the definitions that were applied in AQUACROSS as shown in Table 8 improves accuracy. For instance, the shipping distance is used to estimate shipping extent per stage and is multiplied with the distribution throughout the area of interest for the impact assessment of each ecosystem component. The spatial overlap of each activity with the distribution of each ecosystem component should be evaluated per case study.

Table 8: Spatial extent categories as used in AQUACROSS (Borgwardt et al., 2019).

\begin{tabular}{|l|l|}
\hline Category & $\begin{array}{l}\text { Spatial extent (Spatial overlap of each activity-pressure combination with an } \\
\text { ecosystem component) }\end{array}$ \\
\hline Exogenous & $\begin{array}{l}\text { The activity occurs outside of the area occupied by the ecosystem component, but one } \\
\text { or more of its pressures would reach the ecosystem component through dispersal }\end{array}$ \\
\hline Site & $\begin{array}{l}\text { The activity overlaps with the ecosystem component by up to } 5 \% \text { of the area occupied by } \\
\text { the EC in the case study area }\end{array}$ \\
\hline Local & $\begin{array}{l}\text { The activity overlaps with the ecosystem component by between } 5 \text { and } 50 \% \text { of the area } \\
\text { occupied by the EC in the case study area }\end{array}$ \\
\hline Widespread patchy & $\begin{array}{l}\text { The activity overlaps with the ecosystem component by between } 50 \text { and } 100 \% \text { of the } \\
\text { area occupied by the EC in the case study area, the distribution within that area is patchy }\end{array}$ \\
\hline Widespread even & $\begin{array}{l}\text { The activity overlaps with the ecosystem component by between } 50 \text { and } 100 \% \text { of the } \\
\text { area occupied by the EC in the case study area, and is evenly distributed across that area }\end{array}$ \\
\hline
\end{tabular}

28 of 89 | Wageningen Marine Research report C069/21 


\subsubsection{Dispersal}

The spatial context or dispersal of the pressure depends on the ecosystem the farm is situated in and the associated currents and waterbody size. For example, offshore in the North Sea the effect of nutrient depletion has the potential to extend further but is easier weakened or compensated by the dynamics of the North Sea. In the Eastern Scheldt the spatial extent may be smaller, but the impact is more concentrated (which in the case of the Eastern Scheldt may be compensated due to higher nutrient loading). Note that dispersal is set for pressure, not activity. Set scores are applied, for example for litter and contaminants, dispersal is high (Table 9). Examples for no dispersal are physical barrier to species movement due to cultivation structures/seaweed and entanglement of large fauna in the cultivation system. Underwater and other noise from shipping or machines required for installation or operation is considered as moderate dispersal.

Table 9: Dispersal categories as used in AQUACROSS (Borgwardt et al., 2019) and adapted by Piet et al (North Sea CEA 2020 in progress).

\begin{tabular}{|l|l|r|}
\hline $\begin{array}{l}\text { Dispersal (Effect of the dispersal of the pressure on realized area } \\
\text { of spatial overlap) }\end{array}$ & Category & $\begin{array}{l}\text { Standardized score (0-100), } \\
\text { adapted in 2020 }\end{array}$ \\
\hline The pressure does not disperse in the environment & None & 0 \\
\hline The pressure disperses, but stays within the local environment & Moderate & 75 \\
\hline $\begin{array}{l}\text { The pressure disperses widely and can disperse beyond the local } \\
\text { environment }\end{array}$ & High & \\
\hline
\end{tabular}

\subsubsection{Frequency and persistence (duration)}

The duration of the pressure is divided in the frequency (how often, Table 10) and persistence (how long, Table 11) of the pressure. In terms of frequency the pressure can be continuous, for instance in the case of production of allelochemicals by seaweed (chemical substances that influence the physiology or behaviour of other organisms), or a single or multiple events (such as the introduction of anchors or smothering of benthos due to organic loading). The persistence or duration of the pressure can be short, for example when crushing benthos upon deployment of anchors or the pressure may persist even after decommissioning, for example when introduction of non-synthetic substances and compounds such as heavy metals and hydrocarbons cause pollution. How often and how long the pressure occurs also varies according to the stage of seaweed farming (set-up, cultivation, harvest and decommissioning). For instance shipping occurs more often during installation and decommissioning then during operation.

Table 10: Frequency categories as used in AQUACROSS (Borgwardt et al., 2019) and adapted by Piet et al (North Sea CEA 2020 in progress).

\begin{tabular}{|c|c|c|}
\hline $\begin{array}{l}\text { Frequency (Temporal overlap of each activity-pressure combination with } \\
\text { an ecosystem component) }\end{array}$ & Category & $\begin{array}{l}\text { Standardized score } \\
(0.1-5) \text {, adapted in } \\
2020\end{array}$ \\
\hline $\begin{array}{l}\text { Occurs approximately } 1-2 \text { times in a } 5 \text { year period but may (or may not) } \\
\text { last for several months when it occurs }\end{array}$ & Rare & 0.1 \\
\hline $\begin{array}{l}\text { Can occur in most years over a } 5 \text { year period, but not more that several } \\
\text { times a year }\end{array}$ & Occasional & 0.2 \\
\hline $\begin{array}{l}\text { (1) occurs in most years over a } 5 \text { year period, and more than several } \\
\text { times in each year, or ( } 2 \text { ) can occur in } 1-2 \text { years in a } 5 \text { year period but also } \\
\text { in most months of those years }\end{array}$ & Frequent & 1 \\
\hline Occurs in most months of every year, but is not constant where it occurs & $\begin{array}{l}\text { Very } \\
\text { frequent }\end{array}$ & 2 \\
\hline Constant in most or all months of a 5 year period & Continuous & 5 \\
\hline
\end{tabular}


Table 11: Persistence categories as used in AQUACROSS (Borgwardt et al., 2019) and adapted by Piet et al (North Sea CEA 2020 in progress).

\begin{tabular}{|l|l|l|}
\hline $\begin{array}{l}\text { Persistence (Length of time that is needed for a pressure to } \\
\text { disappears after activity stops) }\end{array}$ & Category & $\begin{array}{l}\text { Standardized score (1-100), } \\
\text { adapted in 2020 }\end{array}$ \\
\hline 0 to $<2 \mathrm{yr}$ & Low & 1 \\
\hline 2 to $<10 \mathrm{yr}$ & Moderate & 6 \\
\hline 10 to $<100 \mathrm{yr}$ & High & 55 \\
\hline The pressure never leaves the system or $>100 \mathrm{yr}$ & Persistent & 100 \\
\hline
\end{tabular}

\subsubsection{Severity}

Severity relates to the severity or the likely sensitivity of an ecosystem component to relevant pressures. Ideally dose-response curves are used to estimate severity. The dose-response relationship, describes the magnitude of the response of an organism or ecosystem component, as a function of exposure (or dose) to an activity or pressure after a certain exposure time. Dose-response relationships can be described by doseresponse curves. For instance, the dose-response relationship for marine mammals exposed to contaminants via food can be described by a logistic function Karman et al. (2009). An example for seaweed is the doseresponse curve of algicidal compounds (a substance used to kill or inhibit the growth of algae a process a.k.a. allelopathy) isolated from the green algae Ulva fasciata, which out of 37 investigated seaweeds showed the strongest algicidal activity against red-tide phytoplankton Heterosigma akashiwo (Alamsjah et al., 2005). However, information on dose-response curves is often not available in which case a simpler low, chronic, acute approach is used. Scores used for severity in AQUACROSS (Borgwardt et al., 2019) and in the more recent North Sea CEA (Piet et al., in progress) indicate percentage mortality.

Table 12: Severity categories as used in AQUACROSS (Borgwardt et al., 2019) and adapted by Piet et al (North Sea CEA 2020 in prep.).

\begin{tabular}{|l|l|l|l|}
\hline Severity & Category & $\begin{array}{l}\text { Standardized score } \\
\text { (Borgwardt et al., } \\
\text { 2019) }\end{array}$ & $\begin{array}{l}\text { Standardized score } \\
\text { (0.001-0.3), adapted } \\
\text { in 2020 }\end{array}$ \\
\hline $\begin{array}{l}\text { An interaction that, irrespective of the frequency and } \\
\text { magnitude of the event(s), never causes a noticeable } \\
\text { effect for the ecosystem component of interest in the } \\
\text { area of interaction }\end{array}$ & Low & & \\
\hline $\begin{array}{l}\text { An impact that will eventually have severe } \\
\text { consequences at the spatial scale of the interaction, if it } \\
\text { occurs often enough and/or at high enough levels }\end{array}$ & Chronic & 0.01 & 0.001 \\
\hline A severe impact over a short duration & Acute & & \\
\hline
\end{tabular}

\subsubsection{Resilience}

The generic resilience (recovery time) of the ecological characteristic is assessed based on its current status in the regional sea and categorized based on recovery times.

Table 13: Resilience categories as used in ODEMM (Knights et al., 2015) and adapted by Piet et al. (North Sea CEA 2020 in prep.).

\begin{tabular}{|l|l|r|}
\hline Resilience & Category & Standardized score (1-100), adapted in 2020 \\
\hline No recovery or $>100 \mathrm{yr}$ & None & 100 \\
\hline 10 to $<100 \mathrm{yr}$ & Low & 55 \\
\hline 2 to $<10 \mathrm{yr}$ & Medium & 6 \\
\hline 0 to $<2 \mathrm{yr}$ & High & 1 \\
\hline
\end{tabular}




\subsection{Risk analysis}

A stepwise approach is generally taken to assess impact risk. First the impact risk can be assessed semi-quantitatively by a combination of expert judgement (using a scoring system). This can be used to prioritise risks, which is the scope of this study, and select the quantitative assessment to focus on. Monitoring of ecosystem components and pressures is used to measure and evaluate the impact through quantitative assessments (such as dose-response relations). Little is known about the ecological effects directly related to seaweed production and quantitative data is generally not available. Information used in describing ecosystem interactions of seaweed farming is often derived from mussel cultivation or other forms of aquaculture (Campbell et al., 2019, Tonk and Jansen, 2019). The aim is to establish a framework over the next years that is gradually more based on quantitative information.

Prioritisation of risks, however also depends on methodology. Several statistical methods are available for the aggregation of the (semi-)quantified relationships across impact chains, e.g. summation, multiplication, averaging, or by taking the maximum (Piet et al., 2017b). Most ERA methods assume additive effects when analysing cumulative pressures (Stelzenmuller et al., 2015) but other possible interactions (e.g., synergistic interactions) between pressures should also be considered (Piet et al., 2017a). The methodology applied for the seaweed framework is based on the most recent formula to calculate instantaneous impact risk and long-term impact risk as used by Piet et al (North Sea CEA 2020 in prep., see formula's in 3.4.4.6 Calculation).

\subsection{Quantitative assessment - Case Study}

\subsubsection{North Sea seaweed cultivation case study}

In order to execute the assessment of the seaweed framework a case study of $500 \mathrm{~km}^{2}$ seaweed cultivation area assumed evenly spread over offshore windfarm (OWF) areas in the Dutch part of the North Sea (NCP, Dutch continental shelf) was chosen. The area of interest for the impact assessment is the total NCP area $\left(60.000 \mathrm{~km}^{2}\right)$. The case study area is based on the total potential seaweed cultivation in $25 \%$ of the current Dutch OWFs (approx. $2000 \mathrm{~km}^{2}$ ). Due to the start-up phase that seaweed farming in the North Sea is currently in, a case study at a much smaller scale (1-6 km²) is perhaps relevant from a business-case point of view. However, the case study of $500 \mathrm{~km}^{2}$ was chosen since it represents a "worst case" scenario in which impact chains of most concern can be made visible.

The following assumptions are made:

1) The seaweed farming area of $500 \mathrm{~km}^{2}$ is equally divided over currently operational OWF's on the Dutch continental shelf ( 5 OWF's, total distance from the coast is $166.2 \mathrm{~km}$, Table 15).

2) The area of interest for the impact assessment is the total NCP area $\left(60.000 \mathrm{~km}^{2}\right)$.

3) The time period chosen is 5 years, according to the time frame after which seaweed farming structures need to be renewed.

4) The amount of shipping movements involved depends on various factors, such as the size of the ship, the type of cultivating system used, whether the system can be left over summer etc. Assumptions are based on activities per $\mathrm{km}^{2}$ seaweed farm using ships with capacity for deployment of $0.02 \mathrm{~km}^{2}$ (2 hectare) cultivation system per ship per day (Table 16). However, considering the large scale of the case study the use of larger ships or a floating platform to reduce shipping is recommended.

5) Assumptions concerning the distribution of the various ecosystem components involved are stated in Table 17.

6) For the criterium dispersal local is defined as $4 x$ the seaweed farm size (total $2000 \mathrm{~km}^{2}$ )

7) The seaweed species Saccharina latissima (sugar kelp), is one of the main cultivated species in Europe and is used in this case study. 
8) For the case study the most commonly practiced seaweed cultivation system of longline systems are assumed, with use of droppers for inoculation.

Here, a semi-quantitative assessment to prioritise impact risks was performed based on expert judgement. A team of 7 researchers with expertise in marine ecology, aquaculture, blue growth and risk assessments (Ruud Jongbloed, Robbert Jak, Jacqueline Tamis, Reinier Nauta, Marnix Poelman, Henrice Jansen and Linda Tonk) performed the semi-quantitative risk assessment by means of multiple workshops. A scoring system was used based on criteria (Table 7) used in recent assessments applied in AQUACROSS and ODEMM (Borgwardt et al., 2019, Knights et al., 2015) in combination with recent adjustments from Piet et al (North Sea CEA 2020 in prep.) to assess the exposure intensity of the pressures and the sensitivity of the ecosystem component.

\subsubsection{Background information}

\subsubsection{Offshore windfarms}

Table 15: Operational offshore windfarms in the North Sea

\begin{tabular}{|c|c|c|c|c|c|c|c|}
\hline OWF's & Turbines & $\begin{array}{l}\text { Turbine } \\
\text { capacity } \\
\text { (MW) }\end{array}$ & $\begin{array}{l}\text { Total } \\
\text { capacity } \\
\text { (MW) }\end{array}$ & $\begin{array}{l}\text { Distance } \\
\text { to shore } \\
(\mathrm{km})\end{array}$ & $\begin{array}{l}\text { Start } \\
\text { (Year) }\end{array}$ & $\begin{array}{l}\text { Depth } \\
\text { (m) }\end{array}$ & Owner \\
\hline $\begin{array}{l}\text { Noordzeewind } \\
\text { (OWEZ) }\end{array}$ & 36 & 3 & 108 & 13 & 2008 & $15-18$ & Nuon, Shell \\
\hline $\begin{array}{l}\text { Prinses Amalia } \\
\text { windpark (PAWP) }\end{array}$ & 60 & 2 & 120 & 23 & 2008 & $19-24$ & Eneco energie \\
\hline Luchterduinen & 43 & 3 & 129 & 23 & 2015 & $18-24$ & Eneco, Mitsubishi \\
\hline Gemini & 150 & 4 & 600 & 85 & 2017 & $28-36$ & $\begin{array}{l}\text { Northland Power, } \\
\text { Siemens, Van oord, } \\
\text { HVC NV }\end{array}$ \\
\hline $\begin{array}{l}\text { Borssele } 1 \text { \& } 2 \\
\text { (ORSTED) }\end{array}$ & 94 & 8 & 752 & 22.2 & 2020 & $14-16$ & Orsted \\
\hline Total & 383 & 20 & 1709 & 166.2 & & & \\
\hline Average & & & & 33.24 & & & \\
\hline
\end{tabular}

\section{$\underline{3.4 .2 .2 ~ S a c c h a r i n a ~ l a t i s s i m a ~}$}

Habitat and ecology: Saccharina latissima (also known as sugar kelp) is a brown algae whose blades can reach a length of up to $2 \mathrm{~m}$. It can grow in clear water to a depth of $20 \mathrm{~m}$, with an optimum depth of 5 to $9 \mathrm{~m}$ (Buck and Buchholz, 2004). It occurs mainly on hard substrate such as rocks, stones and artificial substrate and can successfully be cultivated on longlines. It can live at both lower and moderate currents and at higher flow speeds $\left(1.5 \mathrm{~m}^{-1} \mathrm{~s}^{-1}\right)$ (Buck and Buchholz, 2004). S. latissima is native to Europe and a number of longline offshore cultivation projects have been successfully been carried out in the Irish Sea (UK), the North Sea (Netherlands and Germany), Denmark, Norway and the Atlantic (Spain) (Handa et al., 2013, Marinho et al., 2015, Peteiro and Freire, 2011). The growing season of is in winter and early spring (Bikker et al., 2013). It is mainly cultivated for consumption and the extraction of mannitol and alginate (Bikker et al., 2013).

\subsubsection{Impact risk assessment of the pressures involved with seaweed farming in OWF's in the North Sea}

For the SWF case study assessment expert judgement was used to estimate the impact risk per impact chain. Six criteria (spatial extent, dispersal, frequency, persistence, severity and resilience) (Table 7) were adopted from the risk assessments used in AQUACROSS (Borgwardt et al., 2019) and ODEMM (Knights et al., 2015). The scoring of the different criteria was applied according to the latest updates in the North Sea CEA (Piet et al in prep.) (also see Table 8 to 13). 


\subsubsection{Spatial extent}

The spatial extent is based on an assessment of the area $\left(\mathrm{km}^{2}\right)$ where the activities take place during the different stages that apply to seaweed cultivation, divided by the total area of interest (NCP) and taking into account the spatial overlap with the ecosystem component (EC). The spatial overlap of the EC is determined based on the distribution of the EC in the NCP (Table 17). Most activities, such as deployment, growth and harvest occur at the seaweed farm site resulting in an activity index of $0.0083\left(500 \mathrm{~km}^{2} / 60000 \mathrm{~km}^{2}\right)$. For the EC with a distribution throughout the NCP (quantified as a $100 \%$ ), such as plankton, benthos, fish and marine mammals this results in a spatial extent of 0.83 . The activity shipping, which has a broader or local effect, is determined by the shipping movements necessary for each stage of seaweed cultivation (Table 16). When the activity occurs outside the area occupied by the ecosystem component (for example terrestrial) it is categorized as exogenous.

Although spatially no overlap occurs, one or more of the pressures related to the activity would reach the ecosystem component through dispersal and for that reason exogenous is taken into account, albeit with a low percentage ( $1 \%$ of the highest index). For the spatial extent overlap of the (sub) activities per ecosystem component see Annex 3.

Table 16: Shipping during the different stages and sub-stages of seaweed cultivation. Number of shipping movements per $1 \mathrm{~km}^{2}$ seaweed farm or per $500 \mathrm{~km}^{2}$ SWF. Shipping area is calculated from the average distance to the SWF $(33.24 \mathrm{~km}) \times 2$ (back and forth) $\times 20 \mathrm{~m}$ (width ship plus reach). The shipping index is the area divided by the area of impact which is the NCP $\left(60000 \mathrm{~km}^{2}\right)$.

\begin{tabular}{|c|c|c|c|c|c|c|c|}
\hline $\begin{array}{l}\text { Stages of } \\
\text { seaweed farming }\end{array}$ & Sub-stage & $\begin{array}{l}\text { Shipping involved with } \\
\text { sub activities }\end{array}$ & $\begin{array}{l}\text { Shipping } \\
\text { movements } \\
\text { per km² } \\
\text { SWF (\#) }\end{array}$ & \begin{tabular}{|l} 
Days \\
per \\
$\mathrm{km}^{2}$ \\
SWF \\
(\# \\
days)
\end{tabular} & $\begin{array}{l}\text { Shipping } \\
\text { movemen } \\
\text { ts for } 500 \\
\mathrm{~km}^{2} \text { SWF } \\
\text { (\#) }\end{array}$ & $\begin{array}{l}\text { Shipping } \\
\text { area } \\
\left(\mathrm{km}^{2}\right)\end{array}$ & $\begin{array}{l}\text { Shipping } \\
\text { index }\end{array}$ \\
\hline Installation & & $\begin{array}{l}\text { Deployment cultivation } \\
\text { systems, buoys and } \\
\text { mooring (trampling, } \\
\text { interaction with seafloor) }\end{array}$ & 50 & 50 & 25000 & 33240 & 0.554 \\
\hline \multirow[t]{4}{*}{ Operation } & Inoculation & $\begin{array}{l}\text { Deployment of the } \\
\text { inoculation system }\end{array}$ & 1 & 1 & 500 & 664.8 & 0.01108 \\
\hline & Cultivation & Maintenance & 6 & 6 & 3000 & 3988.8 & 0.06648 \\
\hline & & Monitoring & 1 & 1 & 500 & 664.8 & 0.01108 \\
\hline & Harvesting & Mechanical harvesting & 1 & 1 & 500 & 664.8 & 0.01108 \\
\hline Decommissioning & & $\begin{array}{l}\text { Retrieval of cultivation } \\
\text { systems, buoys and } \\
\text { mooring (trampling, } \\
\text { interaction with seafloor) }\end{array}$ & 50 & 50 & 25000 & 33240 & 0.554 \\
\hline
\end{tabular}

Table 17: Distribution of the ecosystem components (EC) in the case study (CS) area of interest, NCP.

\begin{tabular}{|l|l|l|l|}
\hline Ecosystem component & $\begin{array}{l}\text { Area EC } \\
\text { in CS } \\
\left(\mathrm{km}^{2}\right)\end{array}$ & $\begin{array}{l}\text { Spatial } \\
\text { distribution }\end{array}$ & Description \\
\hline Plankton & 60000 & $100 \%$ & \\
\hline Seaweed \& seagrass & 353 & $0.59 \%$ & Sublittoral along the Dutch coastline (353 km) \\
\hline Epiphytes \& epibionts & 353 & $0.59 \%$ & Associated to seaweed \\
\hline Benthos - on bottom & 60000 & $100 \%$ & Lambers et al 2011 \\
\hline Benthos - off bottom & 7400 & $12.3 \%$ & $\begin{array}{l}\text { Estimated based on shipwrecks, oil \& gas installations and } \\
\text { wind turbines in the North Sea (\% calculated for NCP) } \\
\text { (Coolen, 2017). }\end{array}$ \\
\hline Fish - Adult pelagic \& demersal & 60000 & $100 \%$ & \\
\hline
\end{tabular}




\begin{tabular}{|l|l|l|l|}
\hline Fish - Juvenile fish & 60000 & $100 \%$ & Juvenile fish occur everywhere on the NCP. \\
\hline Avial animals - Seabirds & 60000 & $100 \%$ & Local populations. \\
\hline Avial animals - Migratory birds & 60000 & $100 \%$ & \\
\hline Avial animals - Bats & 60000 & $100 \%$ & \\
\hline Marine mammals & 60000 & $100 \%$ & $\begin{array}{l}\text { (Geelhoed et al., 2020, Piet et al., 2017a) in Piet et al 2017 } \\
\text { (Gilles et al 2016, Geelhoed 2011). }\end{array}$ \\
\hline Hard substrate & 1040 & $5 \%$ & $5 \%$ NCP coarse sand, gravel and rock (Coolen, 2017). \\
\hline Soft sediment & 57000 & $95 \%$ & \\
\hline Water column & 60000 & $100 \%$ & \\
\hline Terrestrial & 1750 & $2.94 \%$ & $5 \mathrm{~km}$ wide strip along the Dutch coastline (353km). \\
\hline
\end{tabular}

\subsubsection{Dispersal}

As mentioned in 3.2.4.2 dispersal of the pressure depends on the ecosystem the farm is situated in and the associated currents and waterbody size. In the case study seaweed cultivation takes place offshore in the North Sea. No dispersal is defined as within the seaweed farm. Moderate dispersal within the local environment is defined as $4 x$ the farm size. When dispersal reaches beyond $4 x$ the farm size this is defined as high dispersal (Table 18). Examples for no dispersal are physical barrier to species movement due to cultivation structures/seaweed and entanglement of large fauna in the cultivation system. Underwater and other noise from shipping or machines required for installation or operation is considered as moderate dispersal. Litter dispersal and dispersal of contaminants are considered high.

Table 18: Dispersal categories

\begin{tabular}{|l|l|c|}
\hline $\begin{array}{l}\text { Dispersal (Effect of the dispersal of the pressure on realized } \\
\text { area of spatial overlap) }\end{array}$ & Category & $\begin{array}{l}\text { Standardized score (0-100), } \\
\text { adapted in 2020 }\end{array}$ \\
\hline The pressure does not disperse in the environment & None & 0 \\
\hline $\begin{array}{l}\text { The pressure disperses, but stays within the local } \\
\text { environment 4x farm size }\end{array}$ & Moderate \\
\hline $\begin{array}{l}\text { The pressure disperses widely and can disperse beyond the } \\
\text { local environment }\end{array}$ & High & 75 \\
\hline
\end{tabular}

\subsubsection{Frequency and persistence (duration)}

For the case study standardized scores are used, see 3.2.3.3.

\subsubsection{Severity}

For the case study standardized scores are used, see 3.2.3.4.

\subsubsection{Resilience}

For the case study resilience categories from Table 13 as used in ODEMM (Knights et al. 2015) and adapted by Piet et al (North Sea CEA 2020 in prep.) are applied to the different ecosystem components that are relevant to the case study. In Table 19 a resilience score is assigned to the relevant EC in the North Sea seaweed cultivation case study. The resilience categories, from table 13, were: low, <2 years; medium, between 2 and 10 years, and high between 10 and 100 years for recovery.

Table 19: Ecosystem components and resilience scores, and category's, .

\begin{tabular}{|l|c|c|}
\hline Ecosystem component & Resilience (ODEMM) & Resilience Category \\
\hline Plankton & 1 & high \\
\hline Seaweed \& seagrass & 6 & medium \\
\hline Epiphytes \& epibionts & 6 & medium \\
\hline Benthos - on bottom & 6 & medium \\
\hline
\end{tabular}




\begin{tabular}{|l|c|c|}
\hline Benthos - off bottom & 6 & medium \\
\hline Fish - Adult pelagic \& demersal & 55 & low \\
\hline Fish - Juvenile fish & 55 & low \\
\hline Avial animals - Seabirds & 55 & low \\
\hline Avial animals - Migratory birds & 55 & low \\
\hline Avial animals - Bats & 55 & low \\
\hline Marine mammals & 55 & medium \\
\hline Hard substrate & 6 & medium \\
\hline Soft sediment & 6 & high \\
\hline Water column & 1 & medium \\
\hline Terrestrial & 6 & \\
\hline
\end{tabular}

\section{$\underline{3.4 .4 .6 \text { Calculation }}$}

As mentioned in 3.3 Risk Analysis there are several ways to calculate impact risk. For the semiquantitative assessment used in our case study two methods to calculate impact risk were compared to provide insight of how much the chosen method influences the result (prioritization of the impact chains by result to estimate impact risk). The first method to calculate impact risk is the most recent formula as used by Piet et al. (North Sea CEA 2020 in prep.). In this method instantaneous impact risk (instant IR, formula $1 \mathrm{~A}$ ) and long-term impact risk (long-term IR, formula 1B) are calculated from the exposure (E) and the effect potential (EP). Note that pressure load ( $P$ load) is not taken into account in our calculation. Pressure load refers to the potential effect and is defined as the magnitude of the pressure and the resistance and resilience to represent the sensitivity of the ecosystem component (North Sea CEA 2020 in prep.).

Impact risk method 1 is calculated as follows:

Formula 1A: Instant IR_1 = Exposure $(E) *$ Effect Potential $(E P)$

Formula 1B: $\quad$ Long term $I R=(100-E) *$ Time lag $/ 100$

Time lag $=\frac{\text { Persistence }+ \text { Resilience }}{2}$

Exposure $(E)=\left(\left(\frac{\text { Extent }}{100}+\frac{\text { Dispersal }}{100}\right)-\frac{\text { Extent }}{100} * \frac{\text { Dispersal }}{100}\right)$

Effect Potential $(E P)=\frac{\text { Effective sensitivity }(\text { Effsens })+\text { Effective recovery }(\text { Effrec })}{100}$

Effective sensitivity $=100 *\left(1-\left((1-\text { Severity })^{\text {Frequency }}\right)\right)$

Effective recovery $=100-\left(100 * \frac{100-\text { Effsens }}{(100-\text { Effsens })+E f f \operatorname{sens} * E X P(\text { Resilience })}\right)$

A second method of calculating impact risk is used as a comparison (Jak and Tamis, 2018). In this method the impact risk is calculated as the average of 4 exposure factors (spatial extent, dispersal, persistence and frequency) and the average of 2 effect factors (severity and resilience). Subsequently exposure and effect are multiplied (formula 2). This second method is comparable to the instant impact risk as calculated by Piet et al. (in prep) and will be referred to as instant IR_2.

Impact risk method 2 is calculated as follows: 


$$
\text { Exposure }(E)=\frac{\text { Spatial extent }+ \text { Dispersal }+ \text { Persistence }+ \text { Frequency }}{4}
$$

$$
\text { Effect }=\frac{\text { Severity }+ \text { Resilience }}{2}
$$

Table 20: Impact risk categories based on the highest impact risk (100\%).

\begin{tabular}{|l|l|l|}
\hline Impact Risk categories & & \\
\hline low & 1 & $0-20 \%$ \\
\hline medium-low & 2 & $20-40 \%$ \\
\hline medium & 3 & $40-60 \%$ \\
\hline medium-high & 4 & $60-80 \%$ \\
\hline high & 5 & $80-100 \%$ \\
\hline
\end{tabular}

\subsubsection{Case study results}

A total of 631 impact chains were identified in the SWF. In Figure 7 a comparison of the impact chains per impact risk category (Table 20) is seen. Instant IR_1 and instant IR_2 show similar patterns. Although in the highest category (5) a large discrepancy exists between both methods (respectively 10 instead of 92 impact chains in category 5 according to methods by Jak (2018) and Piet et al. (in prep.). The highest number of impact chains fall into the low impact risk category when using these latter methods. The long-term impact risk calculation by Piet et al results in a shift to category 3 (medium risk) (Figure 7).

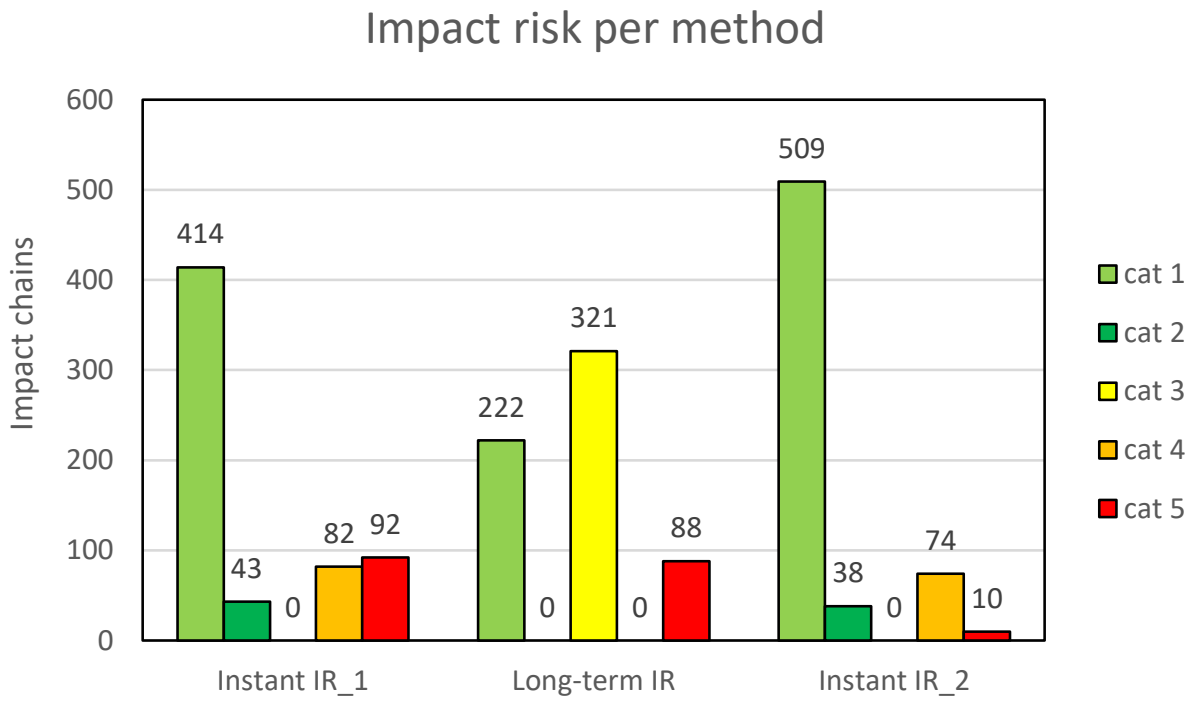

Figure 7: Number of impact risks (IR) chains ( $Y$-axis) per IR category ( $1=$ low risk, $2=$ medium-low risk, $3=$ medium risk, $4=$ medium-high risk and 5=high risk) calculated with different methods (Instant IR_1 and long-term IR vs Instant IR_2, x-axis).

\section{Comparison of prioritisation of pressures by impact risk between methods}

The total impact risk expressed in percentages provides a good means for comparison between methods since the impact risks is not confounded by category boundaries (Figure 8 ). The total impact risk per pressure per method (instant IR_1, long-term_IR and instant IR_2) in Figure 8 shows similar results per method. The pressures "introduction of non-synthetic substances and compounds" and "input of litter" incur the highest percentage of total impact risk, followed by input of anthropogenic sound, input of light, disturbance (visual of fauna) and input or spread of non-indigenous species. Indeed in all three methods the pressure "introduction of non-synthetic substances and compounds" is 
categorized as a high impact risk (category 5, Figure 9 and 10). Input of litter is categorized high when using the calculation according to Piet (Figure 10). Absorption of trace and heavy metals poses a high long-term impact risk, albeit to a lesser extent (in 4 impact chains).

\section{Total Impact Risk (\%)}

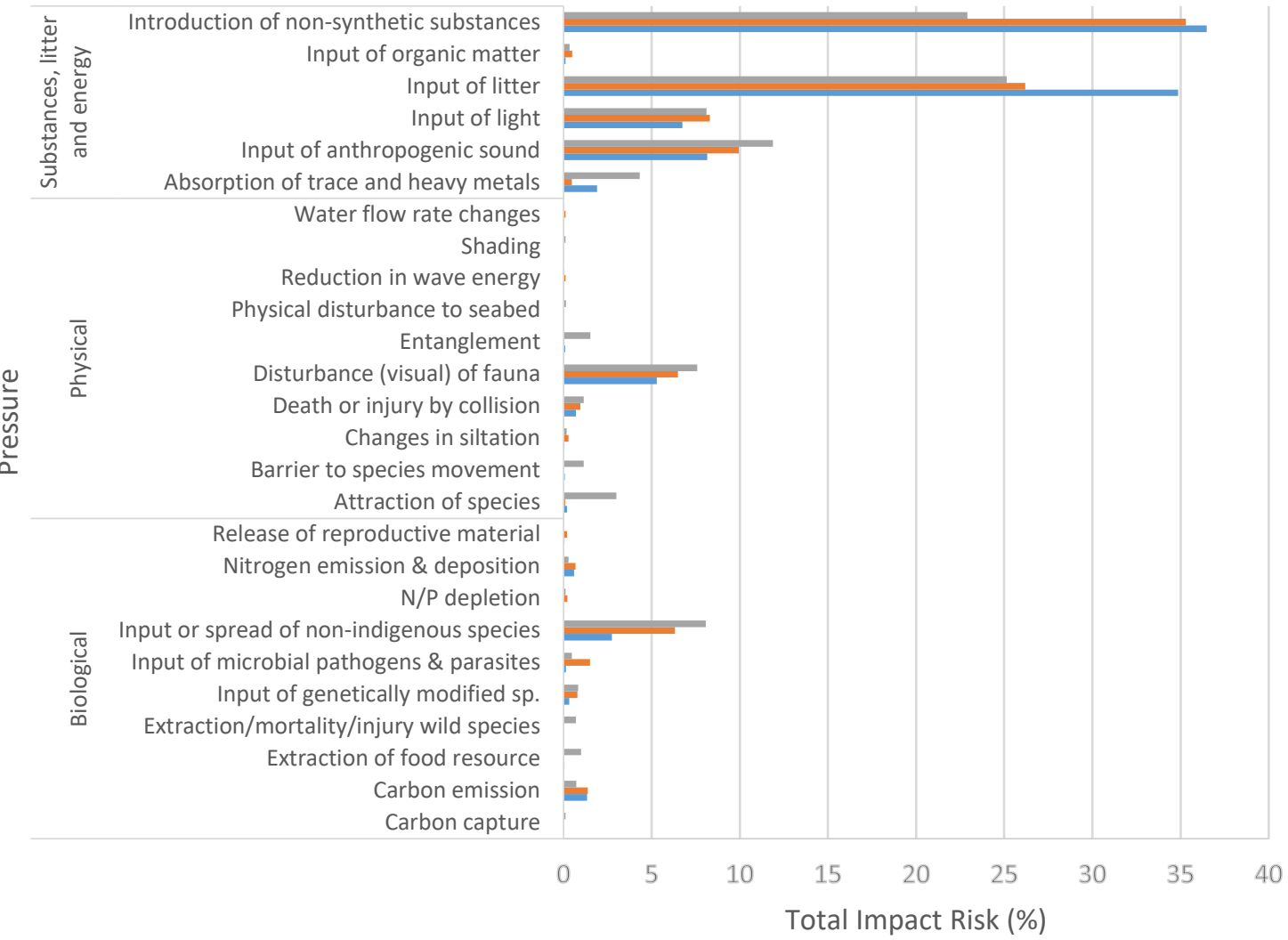

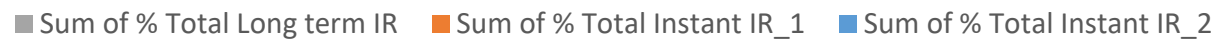

Figure 8: Total impact risk (\%) per pressure per method (instant IR_1, long-term IR and instant IR_2). 


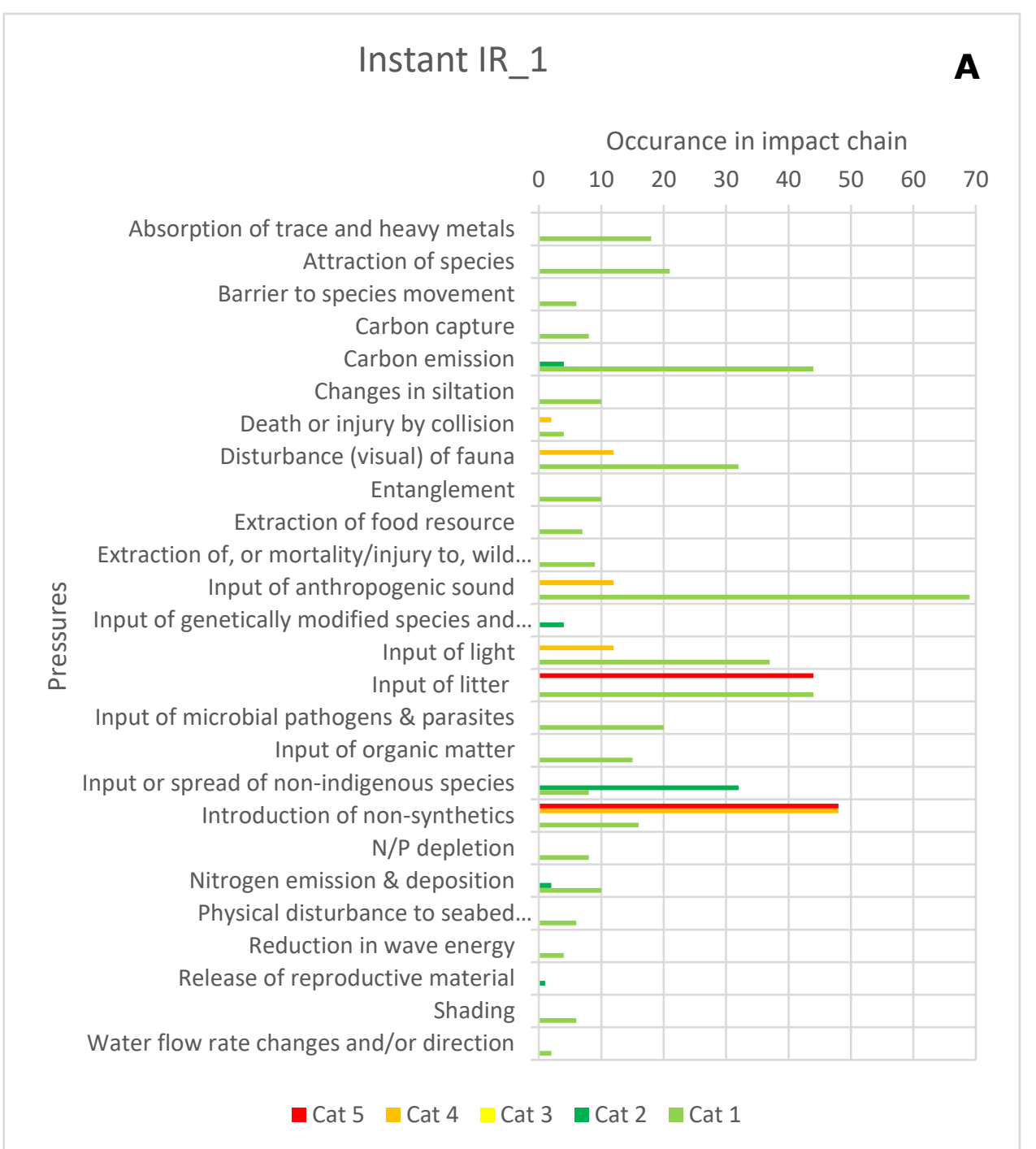

\section{Long-term IR}

B

Occurance in impact chains

$\begin{array}{llllllll}0 & 10 & 20 & 30 & 40 & 50 & 60 & 70\end{array}$

Attraction of species Barrier to species movement

Carbon capture

Carbon emission

Changes in siltation

Death or injury by collision Disturbance (visual) of fauna

Entanglement

Extraction of food resource Extraction of, or mortality/injury to, wild...

Input of anthropogenic sound Input of genetically modified species. Input of light Input of litter Input of microbial pathogens \& parasites Input of organic matter Input or spread of non-indigenous species Introduction of non-synthetics N/P depletion

Nitrogen emission \& deposition Physical disturbance to seabed.

Reduction in wave energy Release of reproductive material Shading

Water flow rate changes and/or direction

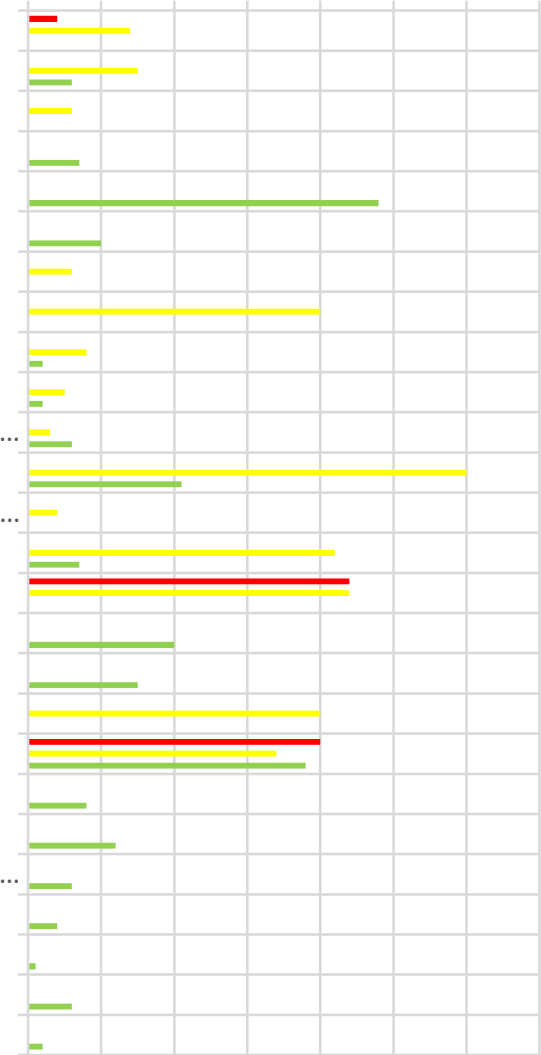

- Cat 5 Cat 4 Cat 3 Cat 2 Cat 1

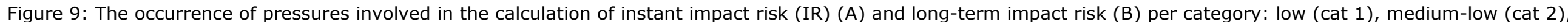
medium (cat 3), medium-high (cat 4) and high (cat 5) impact risk (Piet et al. in prep.). 


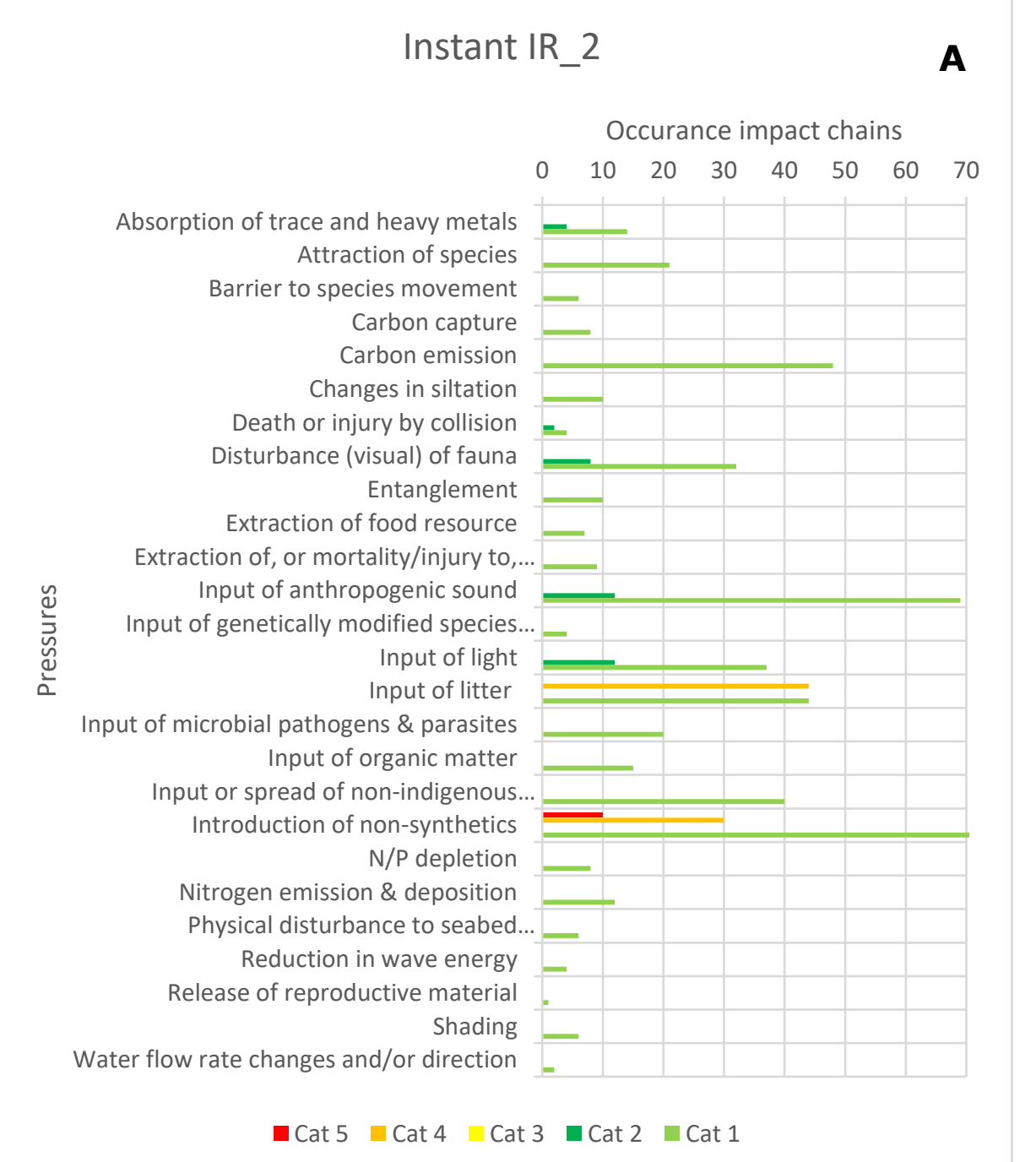

Instant IR_1

Occurance in impact chain $\begin{array}{llllllll}0 & 10 & 20 & 30 & 40 & 50 & 60 & 70\end{array}$

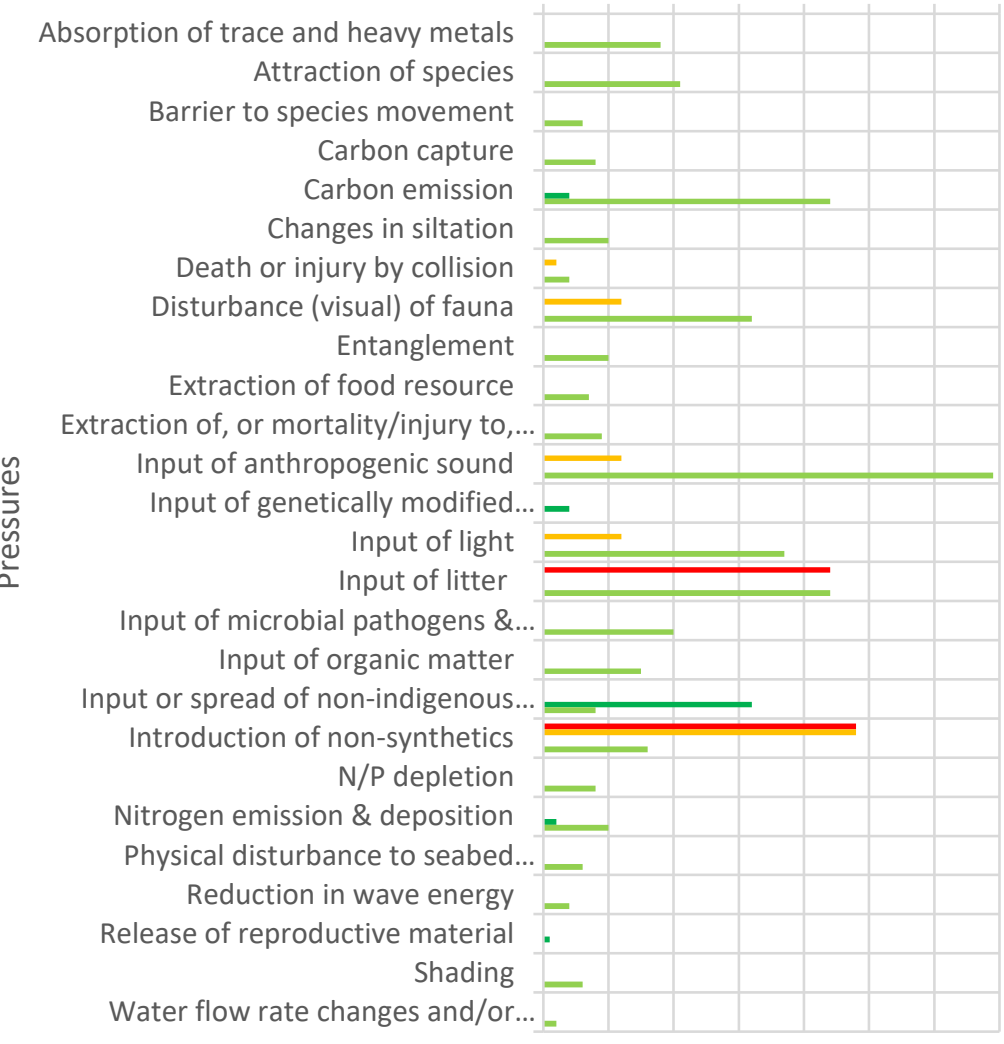

- Cat 5 Cat 4 Cat 3 - Cat 2 - Cat 1

Figure 10: The occurrence of pressures involved in the calculation of instant impact risk_2 (IR) (A) and instant impact risk_1 (B) per category: low (cat 1), medium-low (cat 2), medium (cat 3), medium-high (cat 4) and high (cat 5) impact risk (Piet et al. in prep.). 


\section{Activities and their relative contribution to impact risk}

The total instantaneous impact risk (method Piet et al) per activity stage (operation, installation, decommissioning) is high for the activities shipping, deployment of droppers and longlines and retrieval of the cultivation system and low for monitoring (Figure 11). Annex 5 also shows that high priority impact chains (also see Annex 4) are often linked to shipping activities especially during operation and decommissioning. The pressure introduction of non-synthetic substances and compounds is linked to shipping, deployment and retrieval of droppers and longlines whereas input of litter to deployment and retrieval of droppers and longlines and operational activities such manual labour, cultivation/growth phase and mechanical harvest (Figure 11).

\section{Total Impact risk (\%) per activity}

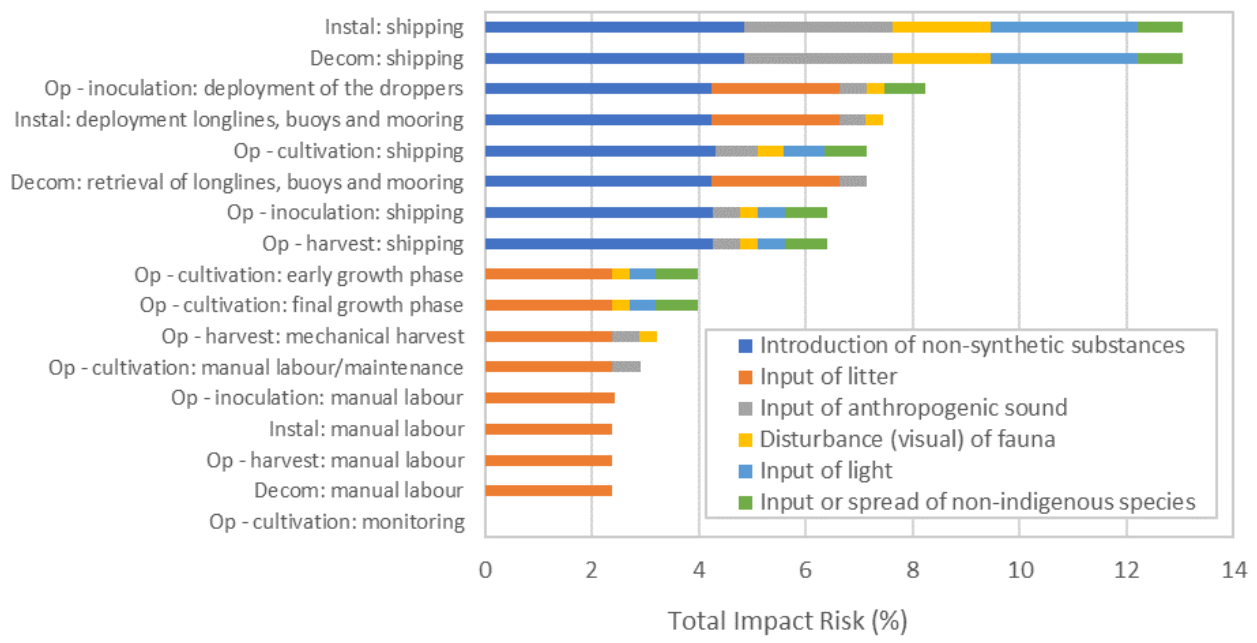

Figure 11: Screening of the relative importance of activities involved with seaweed farming and the contribution of selected pressures to the total instantaneous impact risk (\%). The activities are grouped in different stages: installation (Instal), Operation (Op, which is subdivided in inoculation, cultivation and harvest) and decommissioning (Decom).

\section{Relative impact risk of pressures to the ecosystem components}

The total impact risk per ecosystem component shows that high trophic EC such as avial animals, marine mammals and fish are most at risk compared to low trophic ecosystem components and predominant habitat (Figure 12). High risk pressures are introduction of non-synthetic substances and compounds, input of litter, input of anthropogenic sound, input of light, disturbance (visual of fauna) and only for low trophic EC input or spread of non-indigenous species.

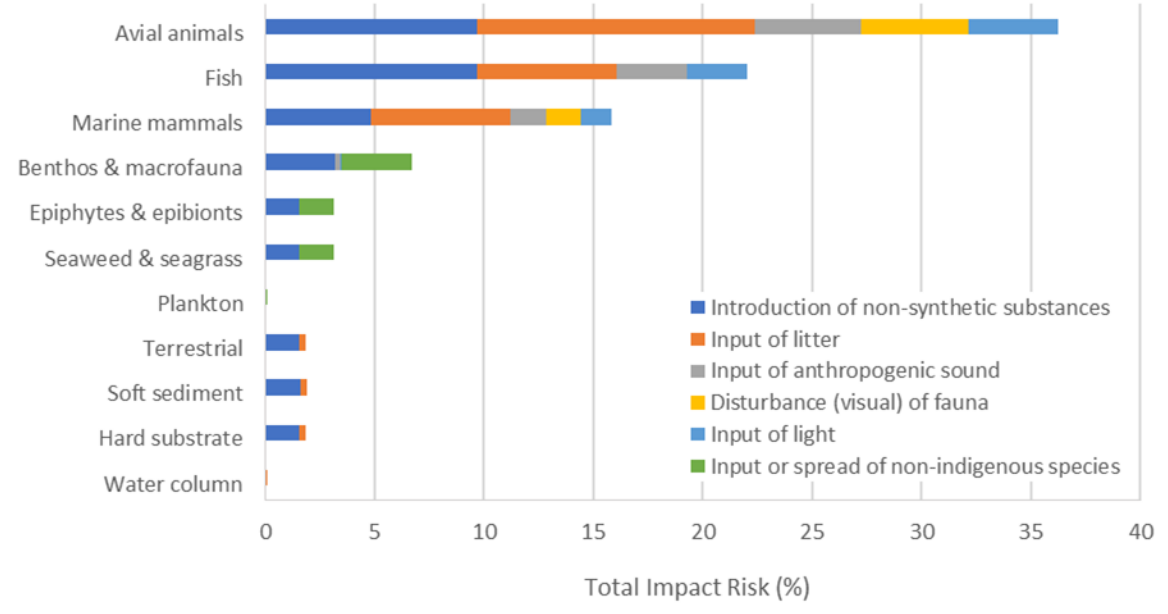

Figure 12: The ecosystem components involved with seaweed farming and the contribution of selected pressures to the total instantaneous impact risk (\%). 
To create more insight in the relative importance of pressures per ecosystem component (EC) the total impact risk of the relevant pressures are grouped in high trophic EC (Figure 13), low trophic EC (Figure 14) and predominant habitat (Figure 15). Besides the importance of pressures such as introduction of non-synthetic substances and input of litter a closer look at the high trophic EC shows that pressures such as disturbance of fauna are relevant for marine mammals and birds but not for fish (Figure 13). Death by collision is only considered as an issue for marine mammals. Absorption of trace and heavy metals shows a small impact risk for fish (note that only direct effects are taken into consideration in the semi-quantitative assessment). Interestingly, short-lived pressures such as disturbance, death by collision, input of light and sound show up in the long-term impact risk (Figure 13).

When ecosystem components (EC) are considered separately or in groups, the relative importance of additional pressures (which would otherwise not be identified due to the low overall impact risk are identified. Zooming in on the low trophic EC shows that, overall, the total impact risks for these ecosystem components appear much lower than the risk involved for high trophic EC. Benthos \& macrofauna is the only group for which a total impact risk of $5 \%$ is reached. Introduction of nonsynthetic substances and, for all EC except plankton, input or spread of non-indigenous species are considered as the most relevant impact risks. For seaweed and epiphytes input of microbial pathogens and parasites may be an additional pressure of concern as well as the pressures input of genetically modified species and carbon emission for just seaweed.

Similar to the low trophic EC the predominant habitats suffer a much lower impact risk compared to the high trophic EC. Of the predominant habitats the water column hardly seems to be effected by the pressures involved, however a long-term impact from input of litter is anticipated. In fact all habitat components appear to be effected by input of litter in the long-term. The total impact risk of introduction of non-synthetic substances scores relatively high for all habitats with the exception of the water column, which is unexpected. 


\section{Total Impact Risk (\%) high trophic EC}

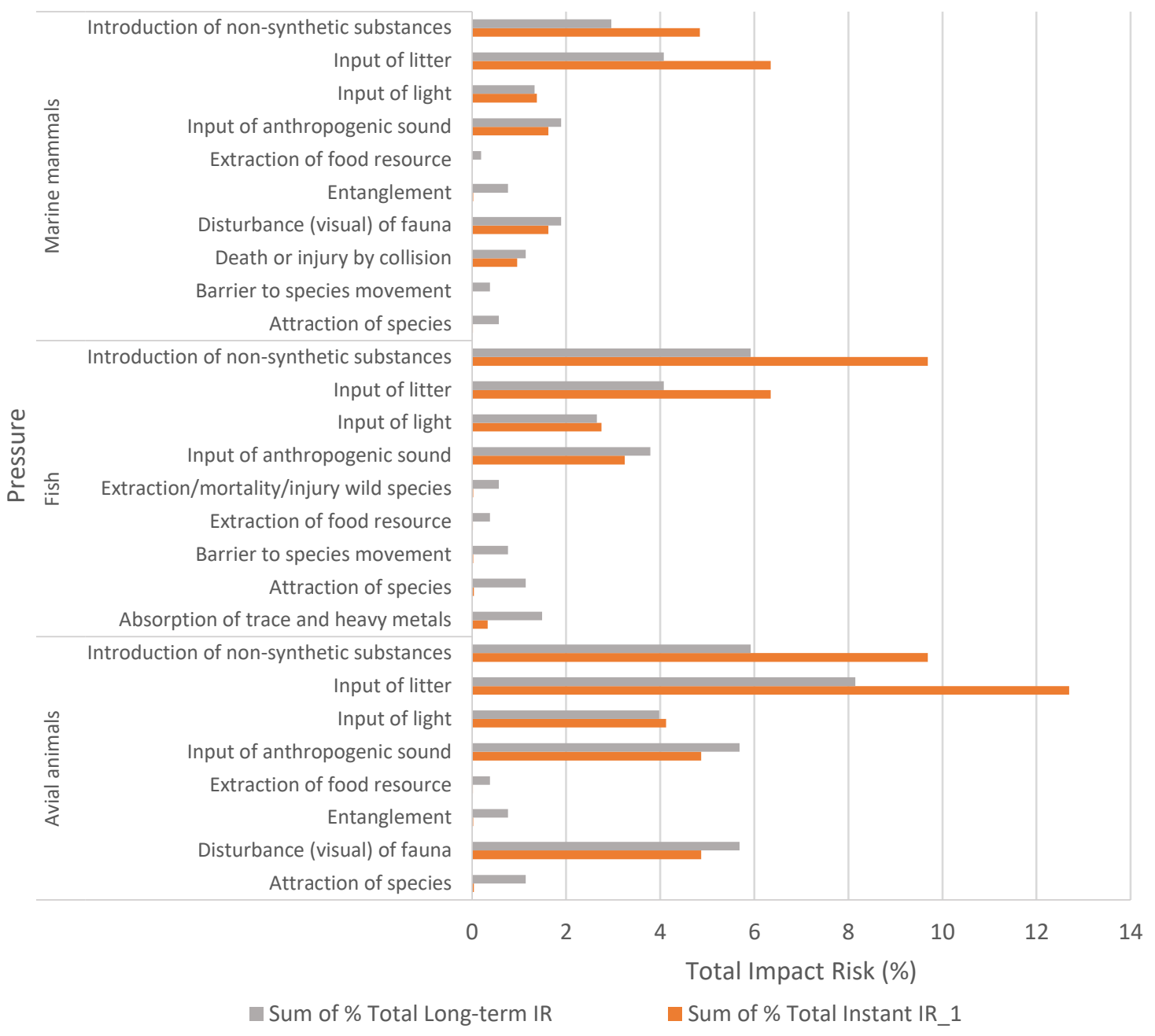

Figure 13: Long term and instantaneous total impact risk (\%) per pressure per high trophic ecosystem component per method (method Piet et al.). 


\section{Total Impact Risk (\%) low trophic EC}

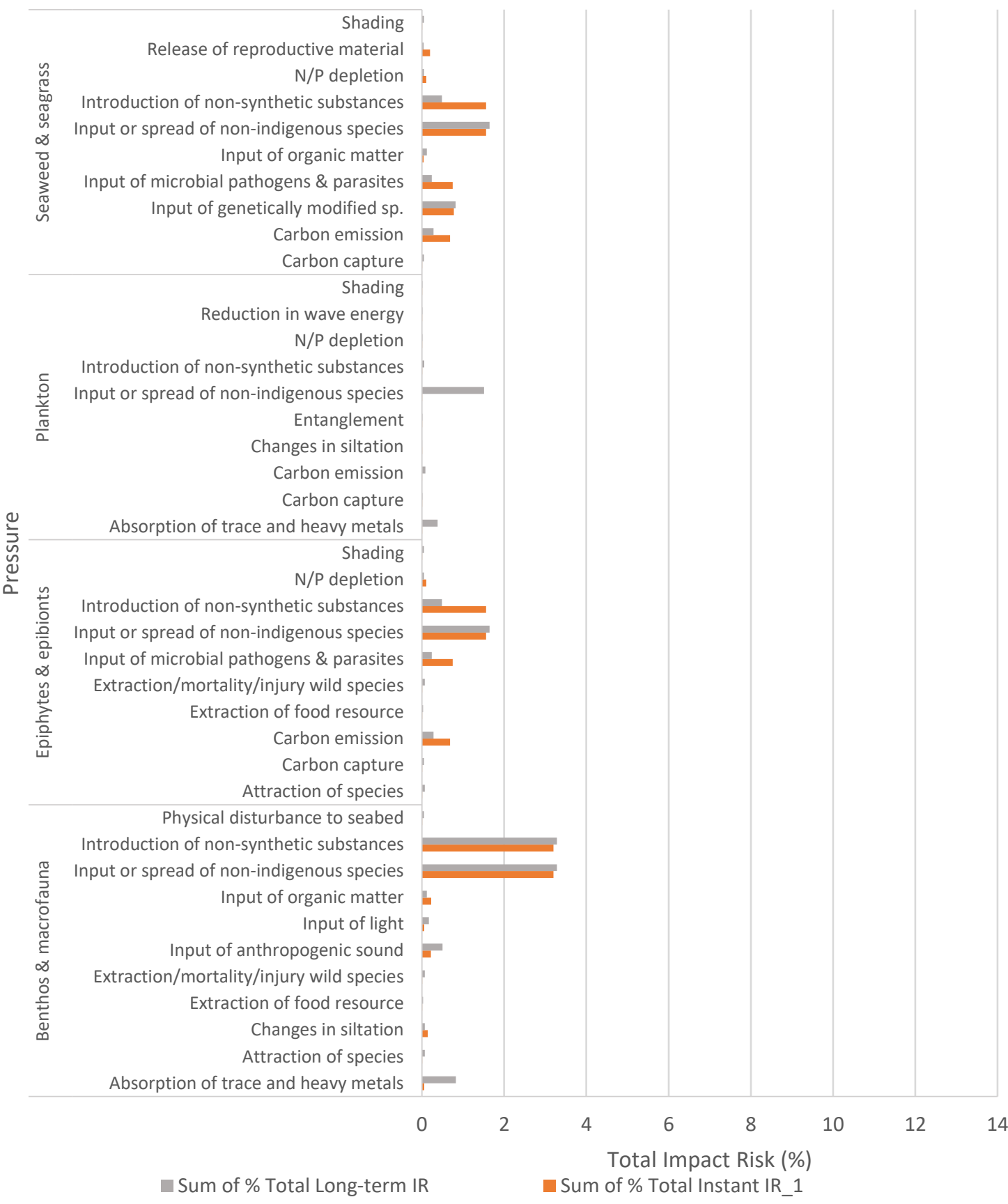

Figure 14: Long term and instantaneous total impact risk (\%) per pressure per low trophic ecosystem component per method (method Piet et al., in prep). 


\section{Total Impact Risk (\%) predominant habitat}

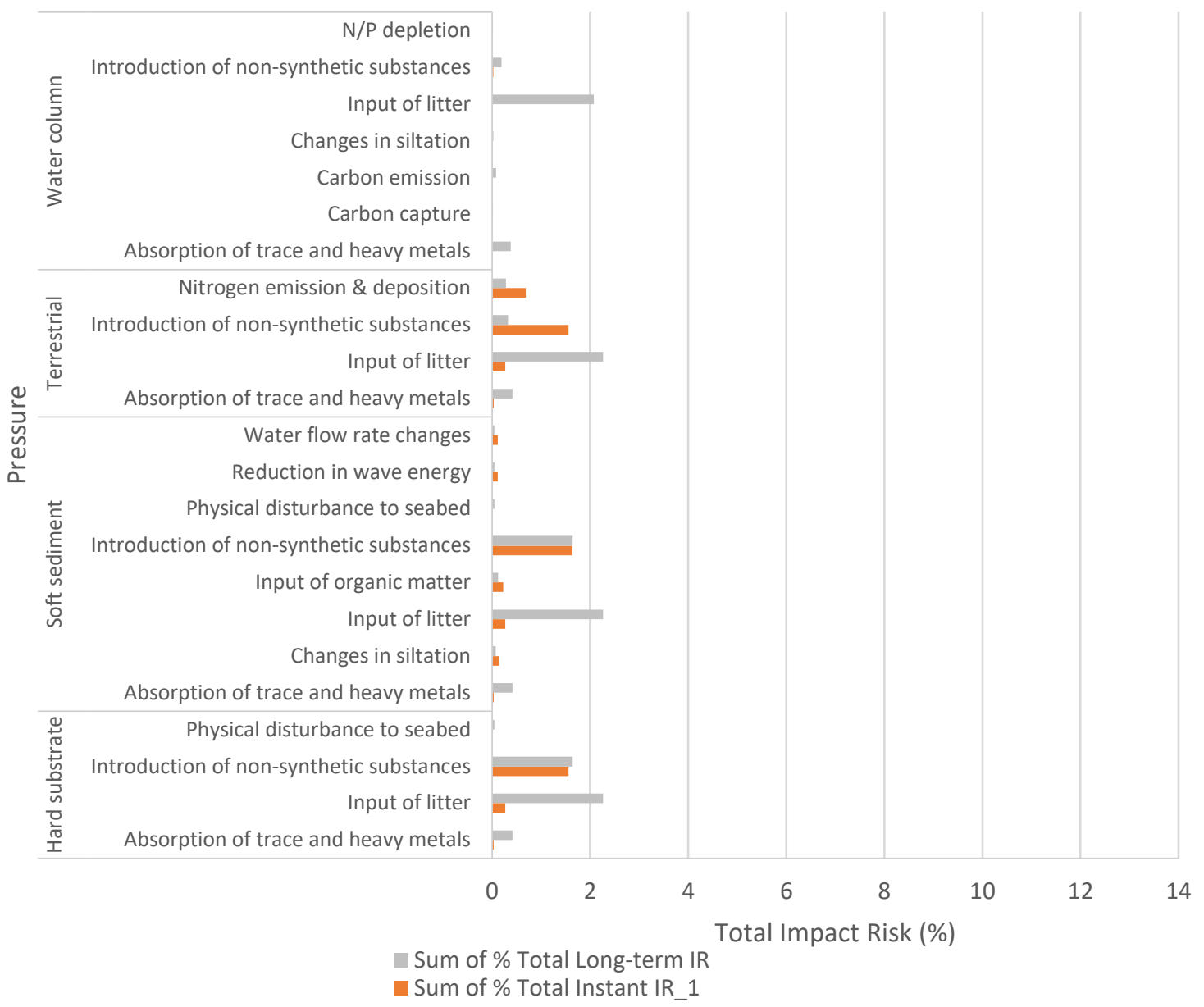

Figure 15: Long term and instantaneous total impact risk (\%) per pressure per predominant habitat ecosystem component per method (method Piet et al. in prep).

\subsubsection{Case study discussion}

\section{Main outcome}

Of the 631 impact chains identified in the seaweed framework most fall into the low impact category when applying the instantaneous impact risk calculation method (Jak and Tamis, 2018, Piet et al., 2019). When incorporating a time-lag in the calculation, by including the average of persistence and resilience, to assess the long-term impact risk most impact chains are categorized medium risk. High priority impact risks include input of litter and introduction of non-synthetic substances and compounds for animals such as fish, birds and marine mammals, especially during operation and decommissioning (often linked to shipping). Results of the methods instantaneous impact risk_1 and impact risk_2 compared best, however when using impact risk categories a large discrepancy in the high impact risk category was apparent (respectively 10 instead of 92 impact chains). When comparing total impact risk (Figure 8 ) the different methods display similar patterns in calculating impact risk.

\section{Comparison between methods}

Two methods were compared (Jak and Tamis, 2018, Piet et al., 2019) to calculate impact risk to provide insight of how much the chosen method influences the result (prioritization of the impact chains by result to estimate impact risk). The same high risk pressure 'introduction of non-synthetic substances' was depicted by both methods, and although input of litter was not considered as a category 5 (high risk) pressure using instantaneous impact risk_2 it was strongly represented in category 4 (medium-high risk). The discrepancy can be explained by the boundaries of the impact risk categories that are divided in $20 \%$ categories based on the highest impact risk value. This becomes 
more obvious when total impact risk is compared between methods (Figure 8), which shows similar patterns. For long term impact risk time-lag is incorporated into the calculation, taking into account the accumulation of impacts over a longer period of time. The results therefore show a shift from low risk categories to medium risks for those pressures where a long-term impact is relevant, such as absorption of trace and heavy metals, input of litter and introduction of non-indigenous species. Indeed the chosen method influences the result (prioritization of the impact chains by result to estimate impact risk), however similar patterns and priority impact chains arise from both methods. The internationally applied method by Piet et al. (2019) is the most advanced method to date (Tamis et al., 2021) and it is the method of choice when it comes to screening impact risk of human related activities and relevant pressures for priority. It should be applied as a first screening to prioritize potential threats that (albeit still work in progress) should provide a solid basis for future work.

\section{Priority impact risks}

Little is known about the environmental impacts surrounding seaweed aquaculture, especially on a large scale such as the North Sea case study. A recent study on the environmental impact of kelp of a small seaweed farm ( 2 ha) in Sweden showed limited negative environmental effects. Instead a positive effect was found on benthic infauna, mobile fauna and other seaweed species. A reduction in light irradiance under the farm was observed due to shading at the peak of the farmed seaweed biomass and no significant effects were observed on the sediment oxygen uptake or in the concentration of dissolved inorganic nutrients ( $\mathrm{NO}_{2}+3$, PO4, and SiO2) (Visch et al., 2020). In a recent hypothetical qualitative risk assessment of the environmental risks associated with the development of large scale (100 ha or $1 \mathrm{~km}^{2}$ ) seaweed cultivation in Europe were assessed. The environmental changes of greatest concern were identified based on the potential vulnerability of ecosystem components along with the magnitude of potential change (Campbell et al., 2019). Changes of greatest concern included: genetic depression of natural algal populations, facilitation of algal diseases, changes to the physical environment through alteration of hydrodynamic regimes, entanglement of mega-fauna, and depletion of natural nitrogen pools in enclosed water bodies (Campbell et al., 2019).

An overview of high priority impact risks depicted by the semi-quantitative assessment of the North Sea seaweed farming case study $\left(500 \mathrm{~km}^{2}\right)$ is provided in Table 21 . The pressures with potential impact risk highlighted by Campbell were at most scored at medium risk in the semi-quantitative assessment. Instead the assessment pointed towards introduction of non-synthetic substances and input of litter (Table 21). Besides the scale difference (100 ha or $1 \mathrm{~km}^{2}$ in Campbell et al. (2019) as opposed to the North Sea case study of $500 \mathrm{~km}^{2}$ ) the semi-quantitative analysis is a more comprehensive assessment taking into account various criteria and therefore differs from the qualitative assessment as undertaken by Campbell et al. The high impact risk pressures from the North Sea case study often emerge in similar type impact risk assessments such as TROPOS, MERMAID and AQUACROSS (Borgwardt et al., 2019, Röckmann et al., 2015, TROPOS, 2014). The nature of non-synthetic substances such as hydrocarbons and heavy metals as well as many types of litter is generally characterized as chronic, persistent in that they can linger in the environment and have the potential of effecting large surfaces and becoming widespread. Moreover most organisms are affected by these pressures resulting in a high manifestation in the impact chain. High impact risk scores are generally associated to high values for the criteria dispersal and persistence (as opposed to the criteria frequency, severity and resilience). When applying the risk assessment system this results in high impact scores indicating that these pressures may easily be underestimated without a systematic screening. The severity of introduction of non-synthetic substances was scored acute for all ecosystem components except for plankton. For the case study the rare occasion of a potential oil spill (a rare event with acute consequences) was chosen as the most relevant potential risk scenario, assuming 'best practice' is applied during human activities such as shipping and maintenance. However, introduction of non-synthetic substances could also apply to other substances that are of a chronic nature (e.g. heavy metals, hydrocarbons, resulting, for example, from pollution by ships and oil, gas and mineral exploration and exploitation, atmospheric deposition, riverine inputs). Indeed, diversity within the category non-synthetic compounds poses a challenge since it may apply to various substances that differ in toxicity and frequency of emission thereby displaying different levels of severity. Severity, therefore, only provides a rough estimate for impact risk and when available should be replaced with data on toxin concentrations in the proximity of a seaweed farm. The same applies 
for input of litter, which was scored as low in our assessment but could in fact also be acute (large debris that is ingested) or chronic (the ingestion of micro-plastics).

Table 21: Overview of high priority pressures based on instantaneous and long-term impact risk (cut-off at $<2 \%$ total IR). Pressures with a high overall impact risk are depicted as overall instant IR and overall longterm IR. Pressures with a low overall IR that are relatively important to a particular EC (based on instantaneous and long-term IR) are depicted as 'per EC'. In the last column pressures with high uncertainty or key knowledge gaps are shown.

High priority pressures

$\begin{array}{lllll}\text { Overall } & \text { Overall } & \text { IR per EC } & \text { Long-term } & \text { Knowledge } \\ \text { Instant IR } & \begin{array}{l}\text { long-term } \\ \text { IR }\end{array} & \text { IR per EC } & \text { gaps }\end{array}$

\begin{tabular}{|l|l|l|l|l|l|}
\hline Introduction of non-synthetic substances & $\mathrm{x}$ & $\mathrm{x}$ & & $\mathrm{x}$ & \\
\hline Input of litter & $\mathrm{x}$ & $\mathrm{x}$ & & $\mathrm{x}$ & \\
\hline Input of anthropogenic sound & $\mathrm{x}$ & $\mathrm{x}$ & & $\mathrm{x}$ & $\mathrm{x}$ (benthos) \\
\hline Disturbance (visual) of fauna & $\mathrm{x}$ & $\mathrm{x}$ & $\mathrm{x}$ & $\mathrm{x}$ & \\
\hline Input of light & $\mathrm{x}$ & $\mathrm{x}$ & & $\mathrm{x}$ & $\mathrm{x}$ \\
\hline Input or spread of non-indigenous species & $\mathrm{x}$ & $\mathrm{x}$ & & $\mathrm{x}$ & \\
\hline Attraction of species & & $\mathrm{x}$ & & $\mathrm{x}$ & \\
\hline Absorption of trace and heavy metals & & & $\mathrm{x}$ & & $\mathrm{x}$ \\
\hline Release of reproductive material & & & $\mathrm{x}$ & $\mathrm{x}$ & \\
\hline Death or injury by collision & & & $\mathrm{x}$ & $\mathrm{x}$ & $\mathrm{x}$ \\
\hline Input of microbial pathogens \& parasites & & & $\mathrm{x}$ & $\mathrm{x}$ & $\mathrm{x}$ \\
\hline Input of genetically modified sp. & & & $\mathrm{x}$ & $\mathrm{x}$ & \\
\hline Carbon emission & & & $\mathrm{x}$ & $\mathrm{x}$ & \\
\hline Nitrogen emission \& deposition & & & & $\mathrm{x}$ & \\
\hline Barrier to species movement & & & & $\mathrm{x}$ & \\
\hline Entanglement & & & & $\mathrm{x}$ & \\
\hline Extraction/mortality/injury wild species & & & & $\mathrm{x}$ & $\mathrm{x}$ \\
\hline Extraction of food resource & & & & $\mathrm{x}$ \\
\hline Changes in siltation & & & & $\mathrm{x}$ \\
\hline Reduction in wave energy & & & & \\
\hline Changes in water flow rate & & & & \\
\hline
\end{tabular}

Other high priority pressures were visual disturbance of fauna, input of anthropogenic sound and input of light. These are short-lived pressures that disappear as soon as the activity stops (low persistence). In our case study the impact risk sometimes scored higher in the long-term. The reason why the impact risk can be higher when time-lag (average of persistence and resilience) is incorporated in the calculation, can lie in the resilience score of the ecosystem component. EC that have a longer recovery time have a higher impact risk in the long-term IR calculation. Within the EC group higher impact risks may result from differences in spatial extent related to the activity the EC is linked to. Zooming in on the ecosystem components and the pressures they are effected by allows us to visualize how pressures with a low overall impact risk affect a particular EC. It shows, for example, the relevance of input or spread of non-indigenous species for all low trophic EC (for plankton only a long-term IR). The relevance of input of microbial pathogens and parasites and carbon emission was highlighted for the EC seaweed \& seagrass and epiphytes \& epibionts and input of genetically modified species for seaweed \& seagrass. Nitrogen emission \& deposition proved only relevant for terrestrial habitat.

\section{Carrying capacity}

Despite the large scale of the North Sea case study the pressure N/P depletion did not score high for impact risk. When zooming in on relevant EC such as plankton, seaweed and epiphytes N/P depletion scores relatively low amongst the related pressures. Capacity in the context of seaweed cultivation in the North Sea refers to the maximum amount of seaweed that can be grown without negative effects on the available nutrients for the growth of other primary producers such as microalgae. The impact risk the farm exerts by extracting nutrients from the water column depends on the size of the 
seaweed farm, the produced seaweed species and the ecosystem or location of the farm (the impact of this particular pressure is likely to be smaller in nutrient rich inshore areas versus offshore areas that have a lower nutrient input). A rough estimate of potential seaweed cultivation within the boundaries of the carrying capacity of the North Sea resulted in $145 \mathrm{~km}^{2}$ seaweed cultivation (based on the assumption that only $5 \%$ of new nutrients from the available nutrient pool is used) (van Duren et al., 2019). This is also in accordance with other nutrient uptake models near large-scale $\left(112 \mathrm{~km}^{2}\right)$ seaweed farms in the North Sea that showed no significant changes in nutrient availability at realistic stocking densities (Aldridge et al., 2021). In addition the case study is based on the assumption that the $500 \mathrm{~km}^{2}$ are spread over the existing OWF. However, it should be taken into account that the generic approach of the assessment is not suitable to deal with concepts such as carrying capacity (when determined by available primary production) which deals with a threshold value instead of a linear relation.

Confidence. In our desk study an in-depth analysis of all available data and the level of confidence was not performed, neither was it in the scope of this exercise. However, a quick scan of the confidence in the available information for each EC-pressure combination was assessed by reviewing the outcome of each combination in terms of whether it was expected, the level of confidence related to this expectation (available data), whether the outcome met our expectations and if not what the potential cause of this was. The resulting key knowledge gaps are included in Table 21. Note that knowledge gaps indicated in Table 21 do not necessarily include all EC. For instance information is available on the effect of anthropogenic sound on marine mammals but little is known of the effect on benthos \& macrofauna. Overall a strong reliance on expert judgement applied, as a result of lack of empirical data. The confidence in the available information concerning the impact of pressures relevant to high trophic ecosystem components was reasonably good. In this category the main uncertainty focused on attraction of species. In the low trophic EC benthos \& macrofauna high uncertainty was ascribed to pressures such as attraction to species, changes in siltation, input of anthropogenic sound and input or spread of non-indigenous species. In the category seaweed \& seagrass high uncertainty was seen in relation to the pressures input or spread of non-indigenous species, input of genetically modified species, input of microbial pathogens \& parasites and release of reproductive material. Although a ban on cultivating non-native species exists, within a seaweed species there is a wide range of strains with various growth ranges and characteristics depending on the location of origin. At the moment a $S$. latissima from Denmark is allowed to be cultivated in the Netherlands because it is the same species, but the consequences of genetic mixing of the various strains are not fully understood. Relevant pressures for the water column scored low in total impact risk. The water column was ranked as resilient. However, the generic approach of the assessment does not allow for a situation such as reaching a tipping point, which may apply to the water column. In that respect the resilience of the water column may be arguable and may lead to an underestimation of total impact risk. Furthermore the soft sediment showed high uncertainty for pressures such as changes in siltation, reduction in wave energy and changes in water flow rate.

Conclusions. High priority pressures indicated by the semi-qualitative assessment based on expert judgement are compiled in Table 21. High trophic ecosystem components are the main groups at risk, however uncertainties surrounding benthos \& macrofauna, seaweed \& epiphytes and soft sediment should also be taken into account. The screening should therefore be seen as a first estimate of priority impact chains based on the criteria applied. Validation of these high priority impact chains is required and necessitates further input of data from monitoring. Key knowledge gaps in seaweed impact chains with a high uncertainty should also be taken into account in exploratory investigations. A better insight in uncertainty surrounding the various impact chains is a logical next step in this process and would place further focus on priority impact chains and knowledge gaps. Taking into account the limitations of the risk assessment framework for seaweed aquaculture as described here currently provides the best guidance for prioritization of impact risks that involve all the relevant activities, pressures and ecosystem components. Further development of the assessment method accompanied by research and monitoring may lead to different outcomes. We emphasize that the current risk assessment framework can be applied in integrated cumulative impact assessments involving pressures that stem from other activities (e.g. fisheries, renewable energy) within that ecosystem. 


\section{Recommendations}

\section{SWF application points of attention}

- $\quad$ Replace criteria categories with data when available

- The use of too much detail in the activity sub-stages can lead to overestimation of impact risk and needs to be avoided as well as the incorporation of double or comparable pressures.

- In addition the level of detail needs to be equal between activity sub-stages to avoid a skewed outcome.

\section{Case study}

- Our case scenario of $500 \mathrm{~km}^{2}$ is extremely large scale in comparison with other large scale studies. The scale difference may lead to a strong emphasis on shipping (linked to spatial extent) considering the assumptions are based on activities per $\mathrm{km}^{2}$ seaweed farm using ships with capacity for deployment of $0.01 \mathrm{~km}^{2}$ (1 hectare) cultivation system per ship per day (Table 16). In practice this results in a lot of shipping back and forth. Considering the large scale of the case study the use of larger ships or a floating platform to reduce shipping is recommended as a mitigation.

Next steps

- Quantification of priority impact risks and key knowledge gaps (see Chapter 4).

- Incorporate ecosystem services to offset impact risks (Campbell et al., 2019). SWF is an impact assessment of all the potential effects of seaweed cultivation on the various EC. Impact implies a negative association. However some activities may result in pressures with a positive effect, so called ecosystem services. These ecosystem services are not taken into account in current impact assessments but have the potential to be incorporated in future EIA's to provide a more comprehensive and balanced estimate of the risks involved with seaweed cultivation. To what extent ecosystem services weigh up to potential impact is an interesting albeit complex issue, especially considering that some pressures can have both positive and negative effects. Ecosystem services can also regress into impacts such as, alleviating high nutrient levels in the North Sea through uptake of nutrients by cultivated seaweed. The nutrient uptake is considered a service but may regress into an impact when seaweed production is too high, resulting in competition for nutrients between naturally occurring seaweed or seagrass and cultivated seaweed.

- SWF can be transformed for specific purposes, by using it as a building block. It is applicable to all extractive forms of aquaculture.

- $\quad$ SWF can be extended and applied to situations where activities that stem from multiple sources (fisheries, renewable energy) interact with the ecosystem (cumulative effects).

- Monitoring to decrease uncertainty or mitigation to decrease risk

- In this study a quick scan was performed to assess the confidence in the available information for each. An in-depth analysis of all available data and the level of confidence would further increase reliability. 


\section{Development of a Toolbox for measurement of Seaweed-Ecosystem interactions}

\subsection{Overview of potential suitable techniques}

The ambition for large scale cultivation of seaweed has been gaining in popularity. In order to ensure a sustainable development of seaweed farming, it is essential to monitor the interaction of seaweed cultivation with marine ecosystems. In this chapter an overview of suitable techniques for monitoring, measuring and evaluating ecosystem interactions of seaweed aquaculture is provided. At this stage no distinction is made between different seaweed species. This effort is organized in three tasks:

Task 1) How to monitor farming activities (intensity, spatial/temporal distribution)

Task 2) How to measure pressures (and link to intensity of activity)

Task 3) How to measure ecosystem response (and link to pressure/activity, dose-response)

Due to the complexity of the ecosystem interactions involved with seaweed farming (a total of 631 impact chains have been described in chapter 3) a pragmatic approach is applied with a focus on high impact risk pressures as well as knowledge gaps. Offshore seaweed farms require a focus on methods and techniques that can be used remotely, ideally providing real-time data to inform the farmer about what is happening in the farm without the necessity of direct visits.

\subsubsection{How to monitor intensity and spatial/temporal distribution of the activity}

The size and location of the seaweed farm are important aspects that need to be considered in the impact assessment as well as in determining the appropriate monitoring program. Current small-scale seaweed cultivation projects ( $<50200 \mathrm{~m}$ lines, comparable to approx. 10 ha or $1 \mathrm{~km}^{2}$ ) are considered low risk (Campbell et al., 2019). However, an expansion of the industry that includes large-scale seaweed cultivation (>50 200m lines) needs a better and more comprehensive understanding of the scale dependent ecosystem interactions in order to balance the environmental impacts with the ecosystem services that seaweed cultivation may offer.

The intensity of the activity is measured by the size or scale of the seaweed farm (cultivation structures and biomass). This is determined by the area the farm occupies (in hectare), the total length and density of the longlines (how far apart the longlines are placed) and the number of anchors and buoys. The biomass of the seaweed depends on the cultivated seaweed species and season (temporal distribution of the activity). The biomass can be quantified by a range of techniques including quantum sensors to measure light absorption, measuring the pull ration changes or remote sensing (Kool and Bernard, 2019). An overview of the available techniques to estimate biomass is provided in Table 22. Techniques to quantify biomass ( 1 to 8 ) are described and ranked in Kool and Bernard (2020). Ranking of these methods according to criteria such as robustness and reliability resulted in a focus on sonar (5), measuring pull forces (2), underwater camera's (4) and modelling (8) as potential viable techniques (for a compilation of techniques to quantify pressures and ecosystem impacts and services related to seaweed farming see Table 22 on page 55).

New technologies have led to a more indirect form of monitoring marine systems, which is more efficient. Remote sensing is such a new technology which was previously mainly used to find large aggregations of fish or underwater topography. The use of sonar for a quantitative and effective means of monitoring seaweed cultivation was investigated (Figure 16) (Lubsch et al., 2020). The 
sonar was able to detect seaweeds and distinguish between the cultivated and filamentous seaweeds growing on the lines and provided a good estimate of the maximum length of the cultivated seaweed. Once validated sonar offers a promising monitoring system to estimate seaweed biomass (Lubsch et al., 2020). The application of force sensors to measure changes in pull ration of seeded and nonseeded droppers to estimate biomass is currently being investigated by Wageningen Plant Research. Underwater image and video techniques could be used to assess the growth visually. This could either be done by cameras attached to the cultivation ropes or by autonomous underwater vehicles, such as drones. While numerous models of underwater cameras are available and this technique provides a direct view on what is happening in the farm disadvantages are the high energy demand, large datafiles and visibility or fouling. Growth models can be applied to estimate biomass and composition based on temperature, light radiance, nitrogen concentration in the water and current speed. Sensors placed in the seaweed farm can measure these environmental parameters to provide indirect measurements of wet and dry weight as well as carbon and nitrogen content in the tissue (Kool and Bernard, 2019).
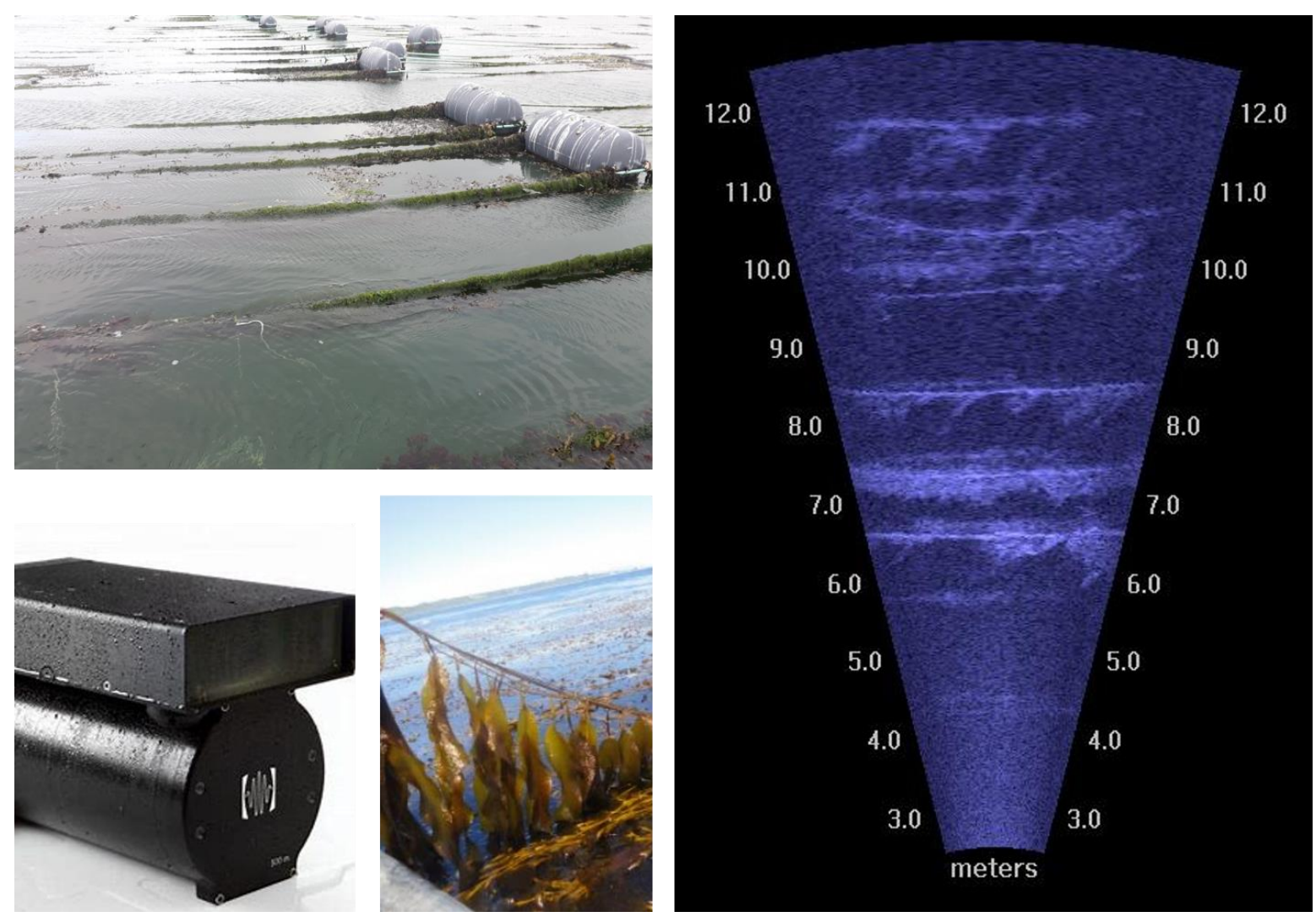

Figure 16: Monitoring of seaweed biomass by means of sonar. Corner left below: image of the DIDSONsonar Diver-held 100m (Cwww.soundmetrics.com), far right: example of sonar observation in a seaweed test farm in the Schelphoek, The Netherlands.

\subsubsection{How to measure pressures and link to intensity of activity}

A prioritisation of the impact risks tailored for the specific situation of each seaweed farm, taking into account the size and the ecosystem the farm is located in as well as the temporal and spatial distribution, is essential prior to monitoring. This is to ensure that uncertainties are addressed and informed decision-making is facilitated. Quantitative data of pressures related to seaweed farming activities and the different ecosystem components is generally not available. This data is needed to feed impact risk assessments data and calls for targeted research on the ecological effects directly related to seaweed production. Examples of pressures that can be monitored are accumulation of organic matter in the sediment (by means of sediment traps), potential of siltation (by means of remote monitoring) or shading caused by the cultivated seaweed measured by quantum sensors. The different pressures that are linked to seaweed cultivation are listed in Table 5. Proposed techniques to measure various pressures are listed in Table 22. Some techniques to measure pressure related parameters are widely used in offshore aquaculture activities. For example the use of MetOcean buoys 
that include multi-parameter applications using onboard oceanographic, meteorological and water quality sensors or the use of acoustic monitoring transponders for subsea survey tasks. The latter are capable of autonomously acquiring acoustic ranges and sensor data without surface control allowing measurements to be made over a long period of time without requiring a surface vessel or ROV to command the process. However, the applicability of many other techniques for monitoring in and around seaweed farms as indicated in Table 22 need further testing.

Both the size of the seaweed farm and the location of the farm determine the intensity of the (sub) activities involved such as logistics (shipping for maintenance) and harvest. Offshore, larger farms are visited less frequently but are further away and require mechanical harvesting and larger boats. A carbon footprint calculator can be developed to measure the total greenhouse gas emissions caused directly and indirectly by a product. Exposure to other pressures from logistics such as noise and collision can be estimated by the frequency of shipping activities (development of automated on-board log system).

\subsubsection{How to measure ecosystem response}

Whereas a quantification of the pressures related to seaweed cultivation is essential to increase confidence of impact risk assessments, monitoring of the ecosystem response is needed to ensure the cultivation is done in a sustainable matter balancing trade-offs between food production and nature conservation The response of the water quality is commonly monitored in aquaculture and various sensors, biosensors, and analytical technologies are available (also see 4.1.2). The four major categories in water quality are (1) physical parameters, e.g., $\mathrm{pH}$, temperature, dissolved oxygen, and salinity, (2) organic contaminants, (3) biochemical hazards, e.g., cyanotoxins, and (4) biological contaminants, i.e., pathogens. An overview of these techniques is provided in Xiaodi et al. (2020).

Ecological indicators such as species richness (biodiversity) and size distribution (of fish or benthos) can also be used to measure ecosystem response. In the past, biodiversity studies have been chiefly based on extractive methods such as fishing or dredging. Due to technical progress in video cameras, sensors, battery life and information storage, novel techniques have become more accessible and affordable. The use of video-techniques has therefore become a powerful tool for monitoring marine biodiversity on different scales, from individuals to entire ecosystems and have been reviewed in Tonk et al. (2018). Baited remote underwater video (BRUV) systems and video transects were tested to identify macro-fauna species and their abundance in close proximity to seaweed farms and showed potential for the current baited camera design (Figure 17) (Lubsch et al., 2021, Tonk et al., 2018). To identify potential biases the system needs to be compared with other methods (transects) and validated. Adjusting the BRUV system design to the specific characteristics of the ecosystem (such as visibility) is one of the recommendations made. While significant advance has been made in regard to technical applications and improvement of experimental set-ups, extracting biologically or ecologically important information from photographs or videos still remains a challenge. For future research, innovative solutions for data processing are essential to ensure the continuing practical use of camera systems. To provide a wider range of identification options, automated visual recognition based on deep learning techniques should also be considered for future development (Lubsch et al., 2021). 


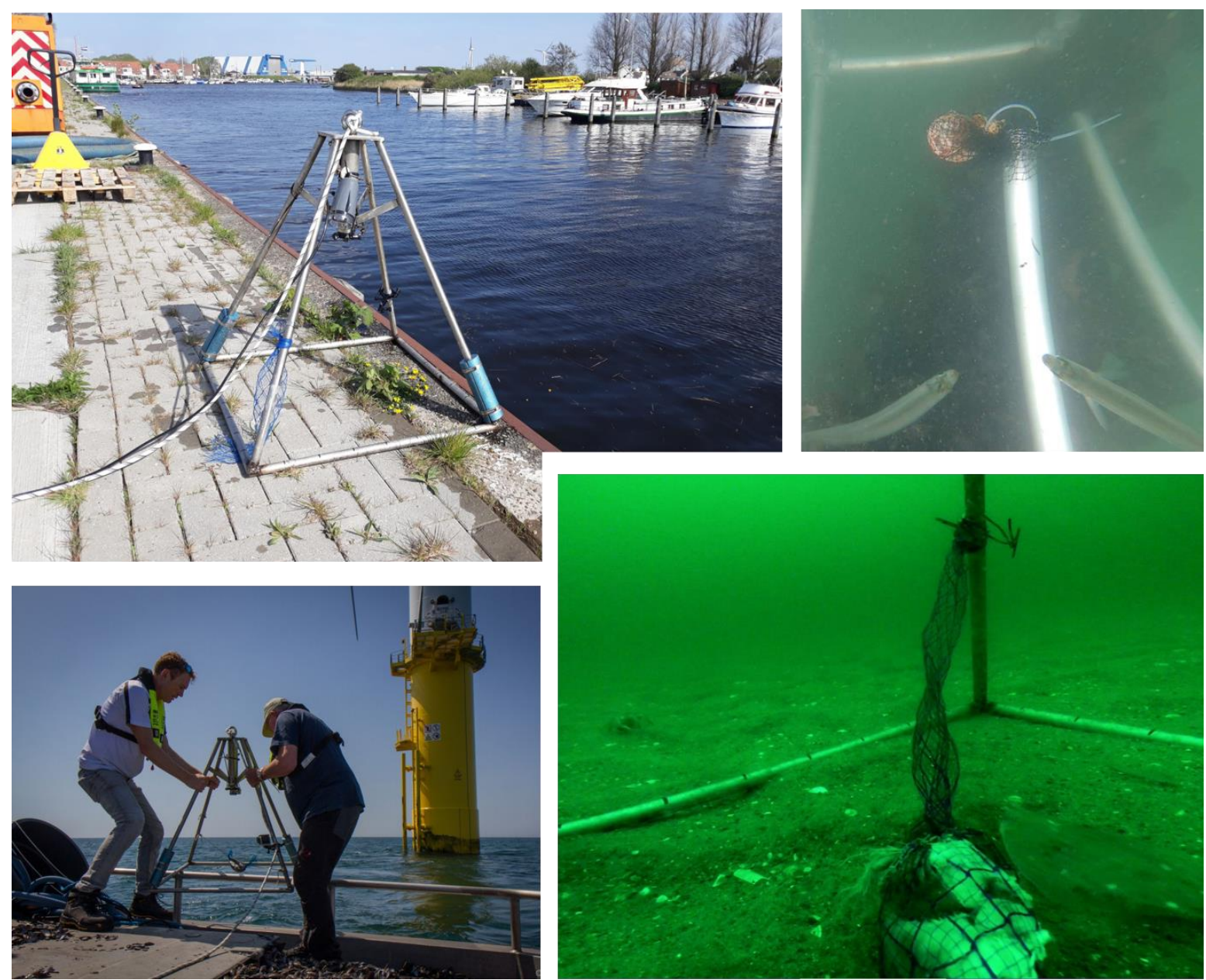

Figure 17: Monitoring fish diversity by means of a baited camera (depicted on the left). Unidentified juvenile fish feeding on the bait (top right).

Recent advancement in high-throughput sequencing has opened ways for the use of molecular identification techniques in biodiversity assessments such as the use of environmental DNA and DNA barcoding options for mobile species identification. The use of DNA metabarcoding for the analysis of flora and fauna in seaweed farms was tested based on bulk samples from settlement plates deployed in an offshore seaweed farm in the North Sea to evaluate the number of sessile organisms attached to the farm structures (Figure 18)(Bernard et al., 2019). The study showed that DNA metabarcoding has a high potential for biodiversity assessments in seaweed farms. Fauna on settlement plates can be readily assessed by DNA metabarcoding, but the inclusion of baseline information $(t=0)$ and/or control sites (pelagic and nearby other hard structures) is crucial for the interpretability and reliability of collected data (Bernard et al., 2019). In addition, preliminary tests have been performed in a seaweed farm in the Eastern Scheldt (Figure 18) for the applicability of environmental DNA (eDNA) in water samples to assess whether mobile fauna, such as fish, can be detected based on traces of their DNA in the water (Bernard et al., 2019). A promising development to assist with this technique is the MinION, an all-in-one portable, real-time sequencing device for DNA that allows monitoring biodiversity through eDNA sequencing in the field. Preliminary tests were successful in detecting a wide range of mobile species however the application of the method in terms of interpretation of results and the experimental design warrants further investigation. For instance, more information is needed on the retention time of DNA in seawater and the distance over which DNA can be transported in the water (Bernard et al., 2019). Quantitative real-time PCR (qPCR) is a PCR-based technique that couples amplification of a target DNA sequence with quantification of the concentration of that DNA species in the reaction. The application of GPCR in ecological studies is well established and also used in seaweed cultivation. For instance qPCR can be used to detect and quantify reproductive material of seaweed (zoospores) in seawater (eDNA samples) (Nagasato et al., 2020). It can also be used as a tool to detect seaweed pathogens (Bernard et al., 2018). Specific qPCR assays can be developed that are fast, reproducible and able to detect minor amounts of target DNA. Population genetics can be used to 
study the impact of gene flow from cultivated seaweed population to wild populations (Mao et al., 2020).
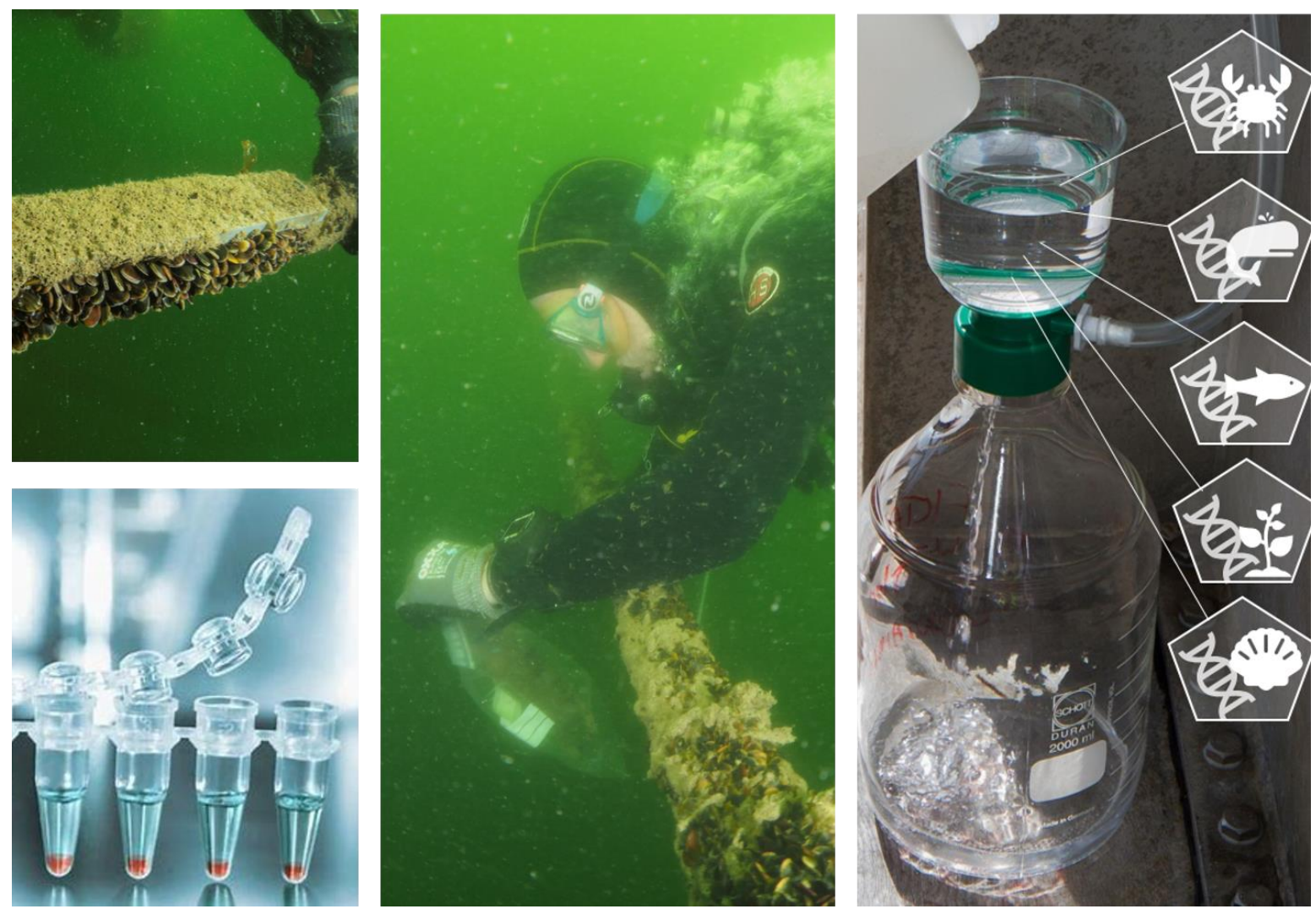

Figure 18: Monitoring biodiversity by means of DNA on settlement plates (top left and middle) and water filtration for eDNA sampling (far right) (photographs by Oscar Bos).

Valve gape monitor meters can be used to monitor gaping cycles of bivalves in order to identify changes in behaviour indicating a disturbance in the marine environment (Andrade et al., 2016, Tonk et al., 2019). Valve gape monitors were tested on flat oysters in a laboratory setting as well as in situ. Combined with environmental parameters such as chlorophyll a, temperature, salinity, current speed and oxygen the valve gape monitors provided insight into environmental stressors and behavioural patterns of the oysters (Figure 19) (Tonk et al., 2019). 

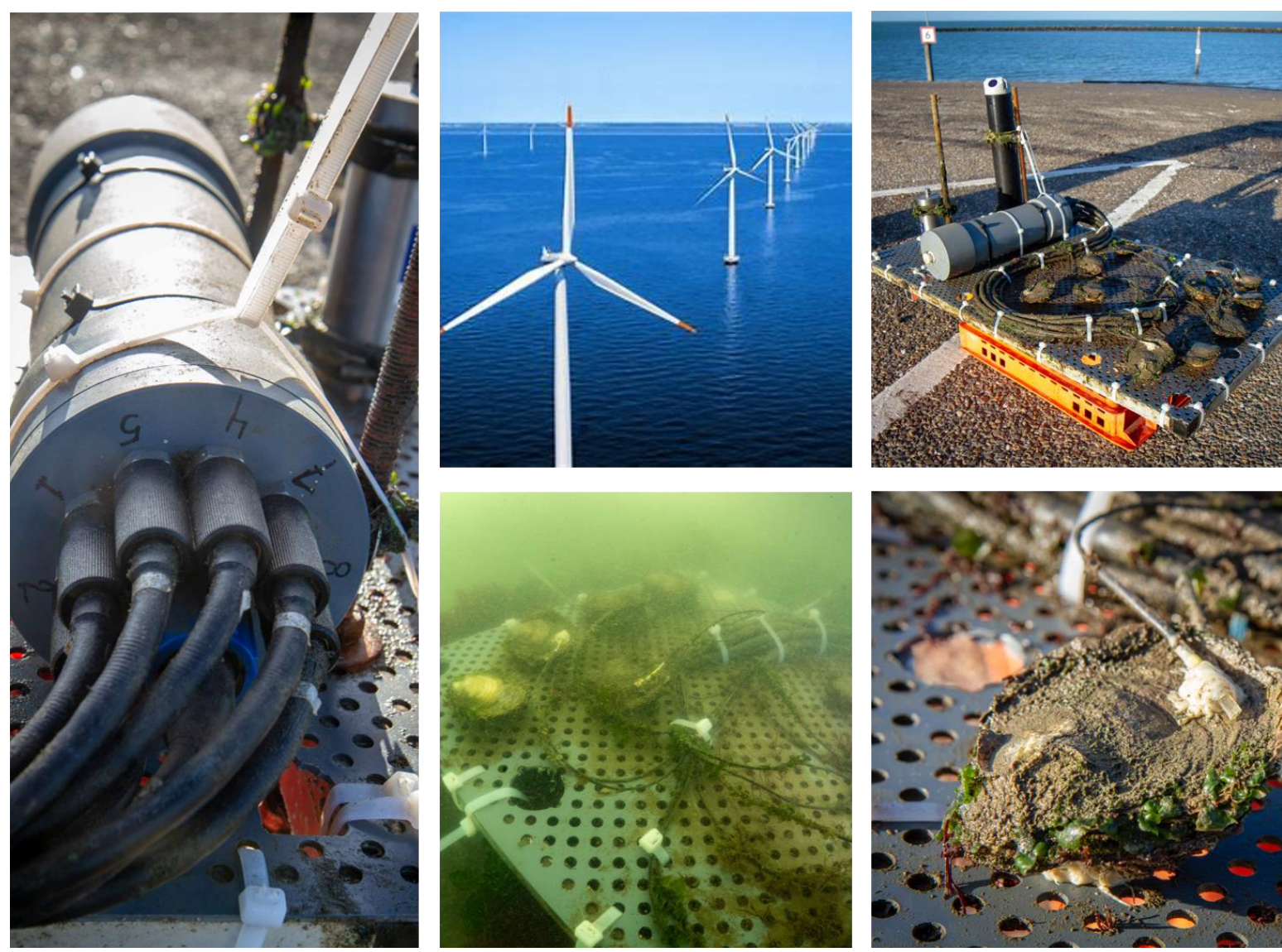

Figure 19: Monitoring of flat oyster gaping cycles. Far left: Valve gape monitor housing. Top right: valve gape monitor housing and sensors attached to oysters chlorophyll meter and current meter. Bottom right: oyster attached to sensor. Middle bottom: arrangement of oysters attached to sensors underwater (photographs of valve gape monitor by Oscar Bos).

Table 22: Techniques to quantify pressures and ecosystem impacts and services related to seaweed farming.

\begin{tabular}{|c|c|c|c|}
\hline Parameter & How to/ innovative tools & Status & Reference \\
\hline \multicolumn{4}{|l|}{ Size SWF } \\
\hline Cultivation area & Measure in surface area $\left(\mathrm{km}^{2}, \mathrm{Ha}\right)$ & Operational & \\
\hline \multirow[t]{2}{*}{ Density } & $\begin{array}{l}\text { Planting density, measured as } \\
\text { substrate }\left(\mathrm{m} \text { or } \mathrm{m}^{2}\right) \text { per surface area } \\
\text { of cultivation area. }\end{array}$ & Operational & \\
\hline & $\begin{array}{l}\text { Seeding density (individuals per } \mathrm{m}^{2} \\
\text { or } \mathrm{m} \text { ) }\end{array}$ & Operational & \\
\hline \multirow[t]{6}{*}{ Biomass } & $\begin{array}{l}\text { 1. Quantum sensors using irradiance } \\
\text { inside and outside the farm }\end{array}$ & Needs validation & $\begin{array}{l}\text { (Kool and Bernard, } \\
\text { 2019) }\end{array}$ \\
\hline & $\begin{array}{l}\text { 2. Force sensors to measure the } \\
\text { pulling strength changes }\end{array}$ & $\begin{array}{l}\text { Needs validation. } \\
\text { Currently tested by } \\
\text { WPR }^{1}\end{array}$ & $\begin{array}{l}\text { (Kool and Bernard, } \\
\text { 2019) }\end{array}$ \\
\hline & $\begin{array}{l}\text { 3. Inclinometer to measure angles of } \\
\text { seeded and unseeded ropes }\end{array}$ & Needs validation & $\begin{array}{l}\text { (Kool and Bernard, } \\
\text { 2019) }\end{array}$ \\
\hline & 4. Drones/underwater imagery & Needs validation & $\begin{array}{l}\text { (Kool and Bernard, } \\
\text { 2019) }\end{array}$ \\
\hline & $\begin{array}{l}\text { 5. Sonar (sound) to estimate the } \\
\text { biomass of seaweed (e.g. DIDSON, } \\
\text { Hummingbird) }\end{array}$ & $\begin{array}{l}\text { Needs validation. Used } \\
\text { to map kelp forests. } \\
\text { Currently tested by WMR }\end{array}$ & $\begin{array}{l}\text { (Kool and Bernard, } \\
\text { 2019, Lubsch et } \\
\text { al., 2020) }\end{array}$ \\
\hline & $\begin{array}{l}\text { 6. LiDAR (Light Detection and } \\
\text { Ranging) works similar to sonar but } \\
\text { with light }\end{array}$ & $\begin{array}{l}\text { Needs validation, } \\
\text { potentially not suitable } \\
\text { for turbid areas }\end{array}$ & $\begin{array}{l}\text { (Kool and Bernard, } \\
\text { 2019) }\end{array}$ \\
\hline
\end{tabular}

\footnotetext{
${ }^{1}$ WPR: Wageningen Plant Research
} 


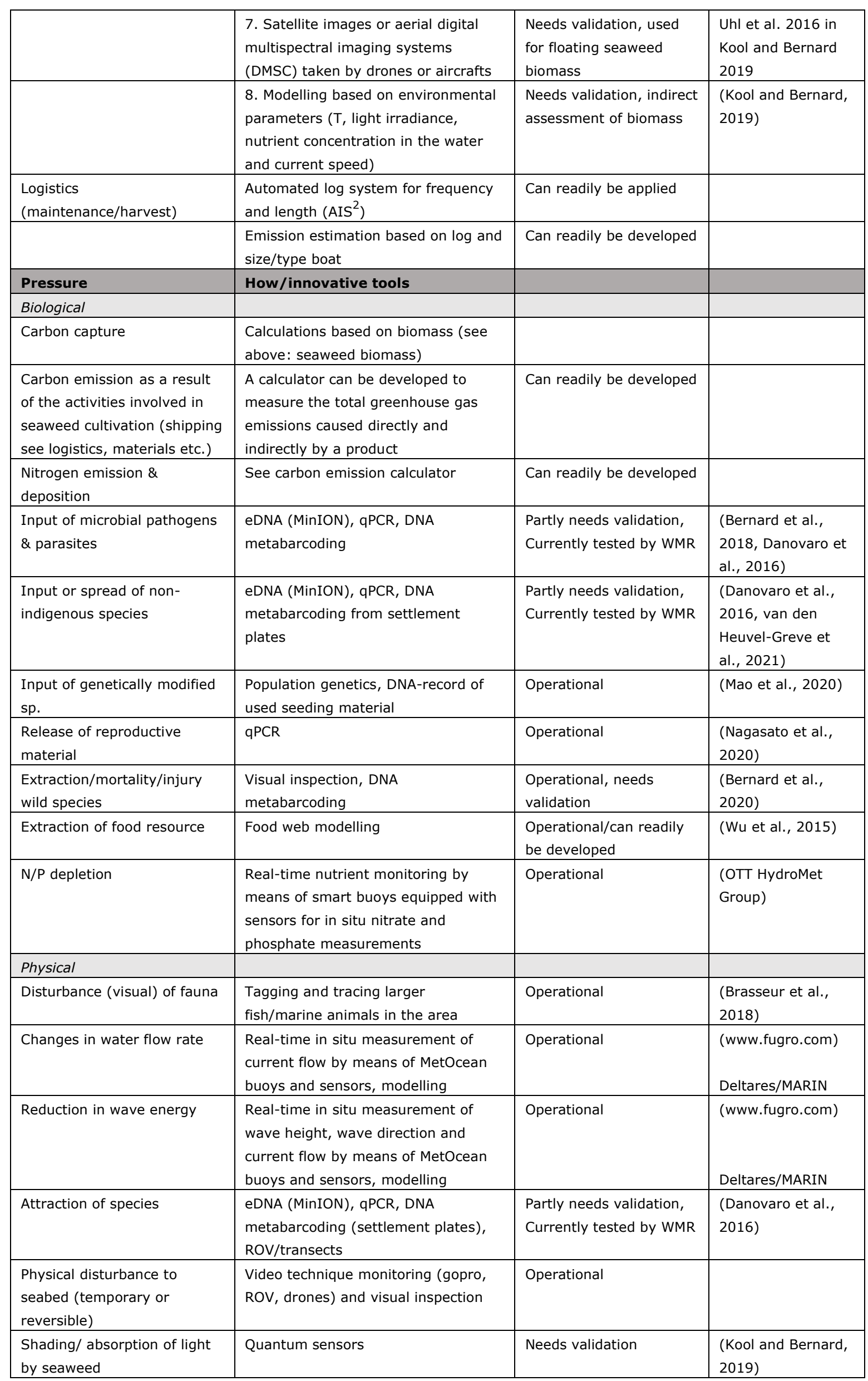

\footnotetext{
${ }^{2}$ AIS: automated identification system
} 


\begin{tabular}{|c|c|c|c|}
\hline Barrier to species movement & $\begin{array}{l}\text { Acoustic monitoring, tagging marine } \\
\text { mammals and fish }\end{array}$ & Operational & $\begin{array}{l}\text { (Danovaro et al., } \\
\text { 2016) }\end{array}$ \\
\hline Death or injury by collision & $\begin{array}{l}\text { Tagging and tracing larger } \\
\text { fish/marine animals in the area }\end{array}$ & Operational & $\begin{array}{l}\text { (Brasseur et al., } \\
2018 \text { ) }\end{array}$ \\
\hline Entanglement & $\begin{array}{l}\text { Video technique monitoring (gopro, } \\
\text { ROV, drones) and visual inspection }\end{array}$ & Operational & \\
\hline Changes in siltation & $\begin{array}{l}\text { Satellite data (NASA-MODIS daily } \\
\text { surface reflectance) - near real time }\end{array}$ & Operational & \\
\hline \multicolumn{4}{|l|}{ Substances, litter \& energy } \\
\hline $\begin{array}{l}\text { Input of organic matter. } \\
\text { Drop-off/organic deposition } \\
\text { of seaweed }\end{array}$ & $\begin{array}{l}\text { Biomarkers, stable isotopes, food } \\
\text { web modelling, sediment traps }\end{array}$ & Needs validation & (Wu et al., 2015) \\
\hline $\begin{array}{l}\text { Introduction of non-synthetic } \\
\text { substances }\end{array}$ & $\begin{array}{l}\text { Chemical sensing kits/in situ } \\
\text { analyser, biomonitors (valve gape } \\
\text { monitors) }\end{array}$ & Operational & $\begin{array}{l}\text { (Andrade et al., } \\
\text { 2016) }\end{array}$ \\
\hline $\begin{array}{l}\text { Introduction of synthetic } \\
\text { compounds }\end{array}$ & $\begin{array}{l}\text { Chemical sensing kits/in situ } \\
\text { analyser, biomonitors (valve gape } \\
\text { monitors) }\end{array}$ & Operational & $\begin{array}{l}\text { (Andrade et al., } \\
\text { 2016) }\end{array}$ \\
\hline $\begin{array}{l}\text { Absorption of trace and } \\
\text { heavy metals (by seaweed or } \\
\text { organisms feeding on } \\
\text { seaweed) }\end{array}$ & $\begin{array}{l}\text { Chemical sensing kits/in situ } \\
\text { analyser, biomonitors (valve gape } \\
\text { monitors), field samples for } \\
\text { laboratory analyses }\end{array}$ & Operational & \\
\hline Input of litter & $\begin{array}{l}\text { Continuous Automated Litter and } \\
\text { Plankton Sampler (CALPS) }\end{array}$ & Operational & $\begin{array}{l}\text { (Danovaro et al., } \\
2016 \text { ) }\end{array}$ \\
\hline Input of anthropogenic sound & Acoustic monitoring/Decibel sensors & Operational & (Aarts et al., 2018) \\
\hline Input of light & Quantum sensors (see above) & Needs validation & \\
\hline \multicolumn{4}{|l|}{$\begin{array}{l}\text { Additional available } \\
\text { techniques }\end{array}$} \\
\hline $\begin{array}{l}\text { Allelochemical production by } \\
\text { seaweed }\end{array}$ & $\begin{array}{l}\text { Chemical sensing kits/in situ analyser } \\
\text { biomonitors (valve gape monitors) }\end{array}$ & Needs validation & $\begin{array}{l}\text { (Andrade et al., } \\
2016 \text { ) }\end{array}$ \\
\hline Estimate seaweed content & $\begin{array}{l}\text { Hyperspectral imaging, fluorescence } \\
\text { (PAM fluorimeter) } \\
\text { RGB: protein derivation from imaging }\end{array}$ & Needs validation & $\begin{array}{l}\text { (Kool and Bernard, } \\
\text { 2019)( Lubsch } \\
\text { 2019) }\end{array}$ \\
\hline Carbon footprint & $\begin{array}{l}\text { A carbon footprint calculator can be } \\
\text { developed as the sum of the excreted } \\
\text { carbon minus the carbon captured. }\end{array}$ & Can readily be developed & \\
\hline $\begin{array}{l}\text { Smothering of benthos due } \\
\text { to organic loading from } \\
\text { seaweed }\end{array}$ & $\begin{array}{l}\text { Biosensors (valve gape monitor), } \\
\text { sediment traps, sediment samples }\end{array}$ & Needs validation & $\begin{array}{l}\text { (Danovaro et al., } \\
\text { 2016, Tonk et al., } \\
\text { 2019) }\end{array}$ \\
\hline \multicolumn{4}{|l|}{ Ecosystem response } \\
\hline Phytoplankton & Chlorophyll a sensors & $\begin{array}{l}\text { Operational / readily } \\
\text { applied }\end{array}$ & \\
\hline $\begin{array}{l}\text { Biodiversity - mobile } \\
\text { (fish/birds) }\end{array}$ & $\begin{array}{l}\text { - Video technique monitoring (BRUV - } \\
\text { baited camera's, ROV, drones) } \\
\text { combined with species ID and } \\
\text { machine learning techniques } \\
\text { - Acoustic sensing (ecoacoustics) } \\
\text { - eDNA (MinION) }\end{array}$ & $\begin{array}{l}\text { - Needs validation, } \\
\text { currently tested by WMR } \\
\text { - operational } \\
\text { - Needs validation, } \\
\text { currently tested by WMR }\end{array}$ & $\begin{array}{l}\text { Sander } \\
\text { Glorius/Hans } \\
\text { Verdaat } \\
\text { (Stowell and } \\
\text { Sueur, 2020) }\end{array}$ \\
\hline Biodiversity - sessile & $\begin{array}{l}\text { DNA metabarcoding of settlement } \\
\text { plates, ROV monitoring, ROV grab } \\
\text { samples }\end{array}$ & $\begin{array}{l}\text { Needs validation, } \\
\text { Currently tested by WMR }\end{array}$ & $\begin{array}{l}\text { Marine vision \& } \\
\text { Robotics, Joop } \\
\text { Coolen }\end{array}$ \\
\hline
\end{tabular}




\begin{tabular}{|c|c|c|}
\hline $\begin{array}{l}\text { Changes in size distribution } \\
\text { and community composition }\end{array}$ & $\begin{array}{l}\text { - Video technique monitoring (BRUV } \\
\text { [baited camera's], ROV, drones) } \\
\text { combined with species ID and } \\
\text { machine learning techniques } \\
\text { - Quantum sensors (see above), in } \\
\text { situ respiration chambers with CTD } \\
\text { measuring effect of turbidity on O2 } \\
\text { uptake and filtration of benthos }\end{array}$ & $\begin{array}{l}\text { - Needs validation } \\
\text { - Needs validation }\end{array}$ \\
\hline
\end{tabular}

\subsection{Recommendations for the case study North Sea seaweed cultivation}

As mentioned a standardized but targeted monitoring tailored to the extent and location of seaweed farms is needed to ensure that uncertainties are addressed and informed decision-making is facilitated. Based on the priority impact risks and knowledge gaps indicated by the semi-qualitative risk assessment in chapter 3 (Table 21) and currently available techniques (Table 22) the following monitoring efforts are suggested based current advancements and synergy between techniques/application (the use of a technique to realise multiple objectives):

Table 23: Recommended monitoring techniques to quantify pressures and ecosystem impacts and services related to seaweed farming: North Sea case study.

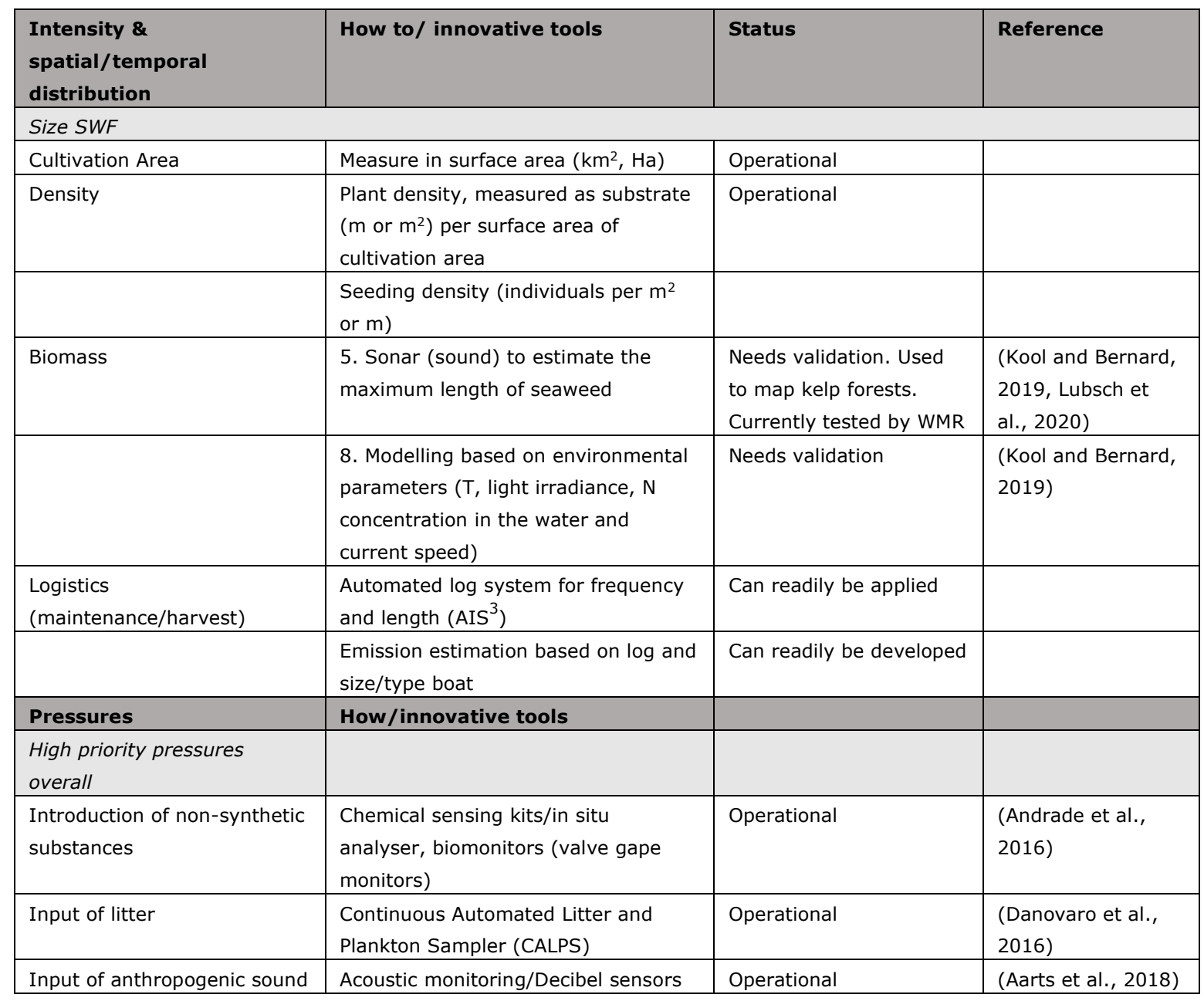

\footnotetext{
${ }^{3}$ AIS: automated identification system
} 


\begin{tabular}{|c|c|c|c|}
\hline Disturbance (visual) of fauna & $\begin{array}{l}\text { Tagging and tracing larger } \\
\text { fish/marine animals in the area }\end{array}$ & Operational & $\begin{array}{l}\text { (Brasseur et al., } \\
\text { 2018) }\end{array}$ \\
\hline Input of light & Quantum sensors (see above) & Needs validation & \\
\hline $\begin{array}{l}\text { Input or spread of non- } \\
\text { indigenous species }\end{array}$ & eDNA (MinION) & $\begin{array}{l}\text { Partly needs validation, } \\
\text { Currently tested by WMR }\end{array}$ & $\begin{array}{l}\text { (Danovaro et al., } \\
\text { 2016), Greve ref? }\end{array}$ \\
\hline Attraction of species & $\begin{array}{l}\text { eDNA (MinION), ROV/transects/DNA } \\
\text { metabarcoding (settlement plates) }\end{array}$ & $\begin{array}{l}\text { Partly needs validation, } \\
\text { Currently tested by WMR }\end{array}$ & $\begin{array}{l}\text { (Danovaro et al., } \\
\text { 2016) }\end{array}$ \\
\hline \multicolumn{4}{|l|}{ Priority pressures per EC } \\
\hline $\begin{array}{l}\text { Input or spread of non- } \\
\text { indigenous species }\end{array}$ & $\begin{array}{l}\text { eDNA (MinION), qPCR, DNA } \\
\text { metabarcoding from settlement } \\
\text { plates }\end{array}$ & $\begin{array}{l}\text { Partly needs validation, } \\
\text { Currently tested by WMR }\end{array}$ & $\begin{array}{l}\text { (Danovaro et al., } \\
\text { 2016, van den } \\
\text { Heuvel-Greve et } \\
\text { al., 2021) }\end{array}$ \\
\hline $\begin{array}{l}\text { Extraction/mortality/injury } \\
\text { wild species }\end{array}$ & $\begin{array}{l}\text { Visual inspection, DNA } \\
\text { metabarcoding }\end{array}$ & $\begin{array}{l}\text { Operational, needs } \\
\text { validation }\end{array}$ & $\begin{array}{l}\text { (Bernard et al., } \\
\text { 2020) }\end{array}$ \\
\hline \multicolumn{4}{|l|}{ Additional knowledge gaps } \\
\hline Changes in siltation & $\begin{array}{l}\text { Satellite data (NASA-MODIS daily } \\
\text { surface reflectance) - near real time }\end{array}$ & Operational & Changes in siltation \\
\hline Reduction in wave energy & $\begin{array}{l}\text { Real-time in situ measurement of } \\
\text { wave height, wave direction and } \\
\text { current flow by means of metocean } \\
\text { buoys and sensors, modelling }\end{array}$ & Operational & $\begin{array}{l}\text { (www.fugro.com) } \\
\text { Deltares/MARIN }\end{array}$ \\
\hline Changes in water flow rate & $\begin{array}{l}\text { Real-time in situ measurement of } \\
\text { current flow by means of metocean } \\
\text { buoys and sensors, modelling }\end{array}$ & Operational & $\begin{array}{l}\text { (www.fugro.com) } \\
\text { Deltares/MARIN }\end{array}$ \\
\hline \multicolumn{4}{|l|}{$\begin{array}{l}\text { Additional available } \\
\text { techniques }\end{array}$} \\
\hline N/P depletion & $\begin{array}{l}\text { Real-time nutrient monitoring by } \\
\text { means of smart buoys equipped with } \\
\text { sensors for in situ nitrate and } \\
\text { phosphate measurements }\end{array}$ & Operational & $\begin{array}{l}\text { (OTT HydroMet } \\
\text { Group) }\end{array}$ \\
\hline $\begin{array}{l}\text { Carbon emission as a result } \\
\text { of the activities involved in } \\
\text { seaweed cultivation (shipping } \\
\text { see logistics, materials etc.) }\end{array}$ & $\begin{array}{l}\text { A calculator can be developed to } \\
\text { measure the total greenhouse gas } \\
\text { emissions caused directly and } \\
\text { indirectly by a product }\end{array}$ & Can readily be developed & \\
\hline \multicolumn{4}{|l|}{ Ecosystem response } \\
\hline $\begin{array}{l}\text { Biodiversity - mobile } \\
\text { (fish/birds) }\end{array}$ & $\begin{array}{l}\text { - Video technique monitoring (BRUV - } \\
\text { baited camera's, ROV, drones) } \\
\text { combined with species ID and } \\
\text { machine learning techniques } \\
\text { - Acoustic sensing (ecoacoustics) } \\
\text { - eDNA (MinION) }\end{array}$ & $\begin{array}{l}\text { - Needs validation, } \\
\text { currently tested by WMR } \\
\text { - Operational } \\
\text { - Needs validation, } \\
\text { currently tested by WMR }\end{array}$ & $\begin{array}{l}\text { Sander } \\
\text { Glorius/Hans } \\
\text { Verdaat } \\
\text { (Stowell and } \\
\text { Sueur, 2020) }\end{array}$ \\
\hline Biodiversity - sessile & $\begin{array}{l}\text { DNA metabarcoding of settlement } \\
\text { plates, ROV monitoring, ROV grab } \\
\text { samples }\end{array}$ & $\begin{array}{l}\text { Needs validation, } \\
\text { Currently tested by WMR }\end{array}$ & $\begin{array}{l}\text { Marine vision \& } \\
\text { Robotics, Joop } \\
\text { Coolen }\end{array}$ \\
\hline Phytoplankton & Chlorophyll a sensors & $\begin{array}{l}\text { Operational/can readily } \\
\text { be applied }\end{array}$ & \\
\hline
\end{tabular}




\section{Conclusions and recommendations}

A risk assessment framework for measuring and evaluating ecosystem interactions is developed that is applicable for a wide range of cultivation methods and areas in the Dutch coastal and delta waters. This framework is a work in progress and functions as a basis/building block to further expand upon. The aim is to link the framework to existing policy objectives, such as the Marine Strategy Framework Directive (MSFD) and its qualitative descriptors of good environmental status (GES). The ultimate goal is to contribute to the development of seaweed cultivation systems balancing trade-offs between food production and nature conservation. There are a number of current challenges involved. One of the challenges (and necessity) is for the government to agree on levels of environmental change that should trigger different management options (i.e., mitigation). The lack of quantitative data concerning the ecological effects directly related to seaweed production calls for targeted research into the effects of seaweed production on the ecosystem. In most cases, data on the dose-response relations of pressures related to seaweed farming activities and the different ecosystem components are not known. This is a knowledge gap that should be addressed in future research. Prioritisation of impact risks based on semi-quantitative assessments (with inclusion of qualitative data when available) and a focus on high priority impact pathways is recommended and should be performed for each seaweed farm individually. An extra challenge is that seaweed cultivation is often one of multiple sectors exploiting a variety of habitat and species in marine ecosystems (Knights et al., 2015, Piet et al., 2019). The combination of these activities and pressures form complex networks of interactions. Due to the complexity of the network the impacts on different ecosystem components are difficult to oversee and manage. Marine and coastal resources management therefore struggle to conserve the marine ecosystem and keep exploitation rates sustainable. As a next step a case study is recommended in which the environmental and ecological impacts of seaweed farming in windfarms will be described in the form of an integrated risk-based effect assessment (iRBEAs) following the example of the seaweed framework described in this report. Ecosystem services are not taken into account in current impact assessments but have the potential to be incorporated in future EIA's to provide a more comprehensive and balanced estimate of the risks involved with seaweed cultivation. To what extent ecosystem services weigh up to potential impact risk is an interesting albeit complex issue, especially considering that some pressures can have both positive and negative effects. How to incorporate ecosystem services to offset impact risks will be explored in a follow up study.

A standardized but targeted monitoring tailored to the extent and location of seaweed farms is needed to ensure that uncertainties are addressed and informed decision-making is facilitated. Typically monitoring of marine cultivation systems is done through labour intensive and intrusive field surveys. With the introduction of new sustainable marine production chains such as the cultivation of seaweeds, economically feasible solutions for production and monitoring should also be included in management processes (Lubsch et al., 2020). In the coming years, the suggested techniques in chapter 4 will be further developed and tested and supplemented with ongoing innovations in techniques. Further development of innovative techniques to determine changes in and around aquaculture farms will contribute to monitoring programs to support careful management of marine resources. 


\section{Glossary}

Environmental Impact Assessment (EIA): A procedure that ensures that the environmental implications of decisions are taken into account before the decisions are made

Environmental Risk Assessment (ERA): A process of predicting whether there may be a risk of adverse effects on the environment caused by a certain activity

Cumulative Effect: the incremental impact of the action when added to the other past, present and reasonably foreseeable actions.

Cumulative Effect assessment (CEA): A systematic procedure for identifying and evaluating the significance of effects from multiple sources/activities and for providing an estimate on the overall expected impact to inform management measures. The analysis of the causes (source of pressures and effects), pathways and consequences of these effects on receptors is an essential and integral part of the process. In this approach we only consider an effect significant if it has an impact on a relevant ecosystem component (Piet et al., 2017a).

Driver: According to DPSIR driver or 'driving force' is a need. Examples of primary driving forces for an individual are the need for shelter, food and water, while examples of secondary driving forces are the need for mobility, entertainment and culture. Here the driver is defined by the sector and activity (Piet et al., 2017a).

Impact chain: Chain linking driver-pressure-state that causes a specific impact.

Impact risk: The contribution of an impact chain to the risk a specific ecosystem component is impacted.

Integrated Cumulative Effect Assessment (iCEA): A CEA explicitly developed to be a receptor-led and fully integrated framework, i.e. involving multiple occurrences of multiple pressures (from single and/or different sources) on multiple receptors, as opposed to other existing approaches dealing with only a subset of those pressures or receptors (Piet et al., 2017a).

Ecosystem Based Management (EBM): The comprehensive integrated management of human activities based on the best available scientific knowledge about the ecosystem and its dynamics, in order to identify and take action on influences which are critical to the health of marine ecosystems, thereby achieving sustainable use of ecosystem goods and services and maintenance of ecosystem integrity (definition taken from OSPAR).

Ecosystem components: Ecologically coherent elements of an ecosystem, that group together more disparate taxonomic groups into the minimum number of elements, based on the view that the lower the number of elements, the easier it is to gain a coherent and integrated assessment across the ecosystem.

Linkage framework: The combination of all the possible linkages through which the Stressor may have an effect on the Receptor. Each linkage is called an impact chain.

Magnitude: The (measurable) level or concentration of the pressure or stressor which is quantitatively and casually linked to the direct or indirect effects on the receptor.

Pressure: The mechanism through which an activity has an effect on any part of the ecosystem. Pressures can be physical (e.g. abrasion), chemical (e.g. introduction of synthetic components) or biological (e.g. introduction of microbial pathogens). 


\section{Quality Assurance}

Wageningen Marine Research utilises an ISO 9001:2015 certified quality management system. This certificate is valid until 15 December 2021. The organisation has been certified since 27 February 2001. The certification was issued by DNV GL.

Furthermore, the chemical laboratory at IJmuiden has NEN-EN-ISO/IEC 17025:2005 accreditation for test laboratories with number L097. This accreditation is valid until $1^{\text {th }}$ of April 2025 and was first issued on 27 March 1997. Accreditation was granted by the Council for Accreditation. The chemical laboratory at IJmuiden has thus demonstrated its ability to provide valid results according a technically competent manner and to work according to the ISO 17025 standard. The scope (L097) of de accredited analytical methods can be found at the website of the Council for Accreditation (www.rva.nl).

On the basis of this accreditation, the quality characteristic $Q$ is awarded to the results of those components which are incorporated in the scope, provided they comply with all quality requirements. The quality characteristic $Q$ is stated in the tables with the results. If, the quality characteristic $Q$ is not mentioned, the reason why is explained.

The quality of the test methods is ensured in various ways. The accuracy of the analysis is regularly assessed by participation in inter-laboratory performance studies including those organized by QUASIMEME. If no inter-laboratory study is available, a second-level control is performed. In addition, a first-level control is performed for each series of measurements.

In addition to the line controls the following general quality controls are carried out:

- Blank research.

- Recovery.

- Internal standard

- Injection standard.

- Sensitivity.

The above controls are described in Wageningen Marine Research working instruction ISW 2.10.2.105. If desired, information regarding the performance characteristics of the analytical methods is available at the chemical laboratory at IJmuiden.

If the quality cannot be guaranteed, appropriate measures are taken. 


\section{References}

AARTS, G., BRASSEUR, S., KIRKWOOD, R., AARTS, G., BRASSEUR, S. \& KIRKWOOD, R. 2018. Behavioural response of grey seals to pile-driving. Den Helder: Wageningen Marine Research.

ALAMSJAH, M. A., HIRAO, S., ISHIBASHI, F. \& FUJITA, Y. 2005. Isolation and structure determination of algicidal compounds from Ulva fasciata. Bioscience Biotechnology and Biochemistry, 69, 2186-2192.

ALDRIDGE, J. N., MOONEY, K., DABROWSKI, T. \& CAPUZZO, E. 2021. Modelling effects of seaweed aquaculture on phytoplankton and mussel production. Application to Strangford Lough (Northern Ireland). Aquaculture, 536.

ANDRADE, H., JEAN-ChARles, M., SABINE, C., DAMIEN, T., PIERRE, C., MOHAMEdou, S. \& LiONEL, C. 2016. High frequency non-invasive (HFNI) bio-sensors as a potential tool for marine monitoring and assessments. Frontiers in Marine Science [Online].

Bernard, M., ROUSVOAL, S., JACQUemin, B., BALLENGHIEN, M., PETERS, A. F. \& LEBLANC, C. 2018. qPCR-based relative quantification of the brown algal endophyte Laminarionema elsbetiae in Saccharina latissima: variation and dynamics of host-endophyte interactions. Journal of Applied Phycology, 30, 2901-2911.

BERNARD, M. S., JANSEN, H., WERF, A. V. D., MEER, I. V. D., TONK, L., BERNARD, M. S., JANSEN, H., WERF, A. V. D., MEER, I. V. D. \& TONK, L. 2020. Development of offshore seaweed farming: ecology \& cultivation : synthesis report 2019. Yerseke: Wageningen Marine Research.

BERNARD, M. S., TONK, L., GROOT, G. A. D., GLORIUS, S., JANSEN, H. M., BERNARD, M. S., TONK, L., GROOT, G. A. D., GLORIUS, S. \& JANSEN, H. M. 2019. Biodiversity monitoring in seaweed farms by DNA metabarcoding using settlement plates and water samples. Yerseke: Wageningen Marine Research.

BIKKER, P., CONTRERAS, A. L., PALSTRA, A. \& BRANDENBURG, W. 2013. A Triple P review of the feasibility of sustainable offshore seaweed production in the North Sea. In: BURG VAN DEN, S., STUIVER, M. \& VEENSTRA, F. (eds.). Wageningen: IMARES.

BORGWARDT, F., ROBINSON, L., TRAUNER, D., TEIXEIRA, H., NOGUEIRA, A. J. A., LILlEBO, A. I., PIET, G., KUEMMERLEN, M., O'HIGGINS, T., MCDONALD, H., AREVALO-TORRES, J., BARBOSA, A. L., IGLESIAS-CAMPOS, A., HEIN, T. \& CULHANE, F. 2019. Exploring variability in environmental impact risk from human activities across aquatic ecosystems. Science of the Total Environment, 652, 13961408.

BRASSeUR, S., PATEL, T. D. V., GeRRodette, T., MEeSters, E., REIJNDERS, P. J. H. \& AARTS, G. 2015. Rapid recovery of Dutch gray seal colonies fueled by immigration. Marine Mammal Science, 31, 405-426.

BRASSEUR, S., SCHOP, J., CREMER, J., AARTS, G., BRASSEUR, S., SCHOP, J., CREMER, J. \& AARTS, G. 2018. Harbour seal monitoring and evaluation for the Luchterduinen offshore windfarm : final report. Texel: Wageningen Marine Research.

BUCK, B. H. \& BUCHHOLZ, C. M. 2004. The offshore-ring: A new system design for the open ocean aquaculture of macroalgae. Journal of Applied Phycology, 16, 355-368.

CALLIER, M. D., BYRON, C. J., BENGTSON, D. A., CRANFORD, P. J., CROSS, S. F., FOCKEN, U., JANSEN, H. M., KAMERMANS, P., KIESSLING, A., LANDRY, T., O'BEIRN, F., PETERSSON, E., RHEAULT, R. B., STRAND, Ø., SUNDELL, K., SVASAND, T., WIKFORS, G. H. \& MCKINDSEY, C. W. 2017. Attraction and repulsion of mobile wild organisms to finfish and shellfish aquaculture: a review. Reviews in aquaculture, 1-26.

CAMPBELL, I., MACLEOD, A., SAHLMANN, C., NEVES, L., FUNDERUD, J., OYERLAND, M., HUGHES, A. D. \& STANLEY, M. 2019. The Environmental Risks Associated With the Development of Seaweed Farming in Europe - Prioritizing Key Knowledge Gaps. Frontiers in Marine Science, 6.

CHAI, Z. Y., HE, Z. L., DENG, Y. Y., YANG, Y. F. \& TANG, Y. Z. 2018. Cultivation of seaweed Gracilaria lemaneiformis enhanced biodiversity in a eukaryotic plankton community as revealed via metagenomic analyses. Molecular Ecology, 27, 1081-1093.

CHRISTIE, H., JORGENSEN, N. M., NORDERHAUG, K. M. \& WAAGE-NIELSEN, E. 2003. Species distribution and habitat exploitation of fauna associated with kelp (Laminaria hyperborea) along the Norwegian coast. Journal of the Marine Biological Association of the United Kingdom, 83, 687-699.

COMMISSION, E. 2008. Directive 2008/56/EC of the European Parliament and of the Council of 17 June 2008 establishing a framework for community action in the field of marine environmental policy (Marine Strategy Framework Directive) (Text with EEA relevance)

COOLEN, J. W. P. 2017. North Sea reefs, benthic biodiversity of artificial and

rocky reefs in the southern North Sea. Wageningen University. 
COUNCIL, E. P. A. 2000. Directive 2000/60/EC of the European Parliament and of the Council of 23 October 2000 establishing a framework for Community action in the field of water policy

DANOVARO, R., LAURA, C., MARCO, B., ABIGAIL, E. C., SUSANA, C., ANNE, C., CINZIA, C., SONIA, C., ROMAIN, R. D. D., ANTONIO, D. A., NINA, D., ESTHER, G. S., JOSEP, M. G., PRISCILA, G., JEANPIERRE, F., ISABEL, F., RODNEY, F., ANDREY, A. K., EUGENIO, R., VESELKA, M., PETER, I. M., SNEJANA, M., ALICE, N., JOHN KENNETH, P., SOPHIE GENEVIEVE, P., ALBERT, R., NAIARA, R.-E., VINCENZO, S., STEFAN, G. H. S., KREMENA, S., CHRISTIAN, W., MARCO LO, M., SilVESTRO, G., SABINE, C. \& ANGEL, B. 2016. Implementing and innovating marine monitoring approaches for assessing marine environmental status. Frontiers in Marine Science [Online].

DE VRIES, P., TAMIS, J. E., FOEKEMA, E. M., KLOK, C. \& MURK, A. J. 2013. Towards quantitative ecological risk assessment of elevated carbon dioxide levels in the marine environment. Marine pollution bulletin, 73, 516-23.

ESTES, J. A. \& DUGGINS, D. O. 1995. Sea Otters and Kelp Forests in Alaska - Generality and Variation in a Community Ecological Paradigm. Ecological Monographs, 65, 75-100.

FAO 2009. Environmental impact assessment and monitoring in aquaculture. Rome: FAO Fisheries and Aquaculture.

FAO 2018. The global status of seaweed production, trade and utilization. Globefish Research Programme. Rome.

GEELHOED, S. C. V., JANINHOFF, N., LAGERVELD, S. \& VERDAAT, H. J. P. 2020. Marine mammal surveys in Dutch North Sea waters in 2019. Den Helder: Wageningen Marine Research.

HAMMER, R. M. 1981. Day-Night Differences in the Emergence of Demersal Zooplankton from a Sand Substrate in a Kelp Forest. Marine Biology, 62, 275-280.

HANDA, A., FORBORD, S., WANG, X., BROCH, O. J., DAHLE, S. W., STORSETH, T. R., REITAN, K. I., OLSEN, Y. \& SKJERMO, J. 2013. Seasonal- and depth-dependent growth of cultivated kelp (Saccharina latissima) in close proximity to salmon (Salmo salar) aquaculture in Norway. AQUACULTURE AMSTERDAM-, 414/415, 191-201.

HASSELSTROM, L., VISCH, W., GRONDAHL, F., NYLUND, G. M. \& PAVIA, H. 2018. The impact of seaweed cultivation on ecosystem services - a case study from the west coast of Sweden. Marine Pollution Bulletin, 133, 53-64.

HEHRE, E. J. \& MEEUWIG, J. J. 2016. A Global Analysis of the Relationship between Farmed Seaweed Production and Herbivorous Fish Catch. Plos One, 11.

INGLE, K. N., POLIKOVSKY, M., CHEMOdANOV, A. \& GOLBERG, A. 2018. Marine integrated pest management (MIPM) approach for sustainable seagriculture. Algal Research-Biomass Biofuels and Bioproducts, 29, 223-232.

JAK, R. G., LUBSCH, A., BEIER, U., JAK, R. G., LUBSCH, A. \& BEIER, U. 2020. Haalbaarheid van het aanlanden van zeesla uit de Waddenzee : randvoorwaarden en richtlijnen voor het oprichten van een commerciële aanvoerstroom. Den Helder: Wageningen Marine Research.

JAK, R. G. \& TAMIS, J. 2018. North Sea Energy II. Screening impacts of offshore infrastructures on marine species groups: a North Sea case study for system integration. Den Helder: Wageningen Marine research.

JANSEN, H. M. \& TONK, L. 2019. Zeewierproductie en biodiversiteit: Ecosysteem diensten en/of ecologische impacts. Yerseke: Wageningen Marine Research (WMR).

JIANG, Z. B., CHEN, Q. Z., ZENG, J. N., LIAO, Y. B., SHOU, L. \& LIU, J. J. 2012. Phytoplankton community distribution in relation to environmental parameters in three aquaculture systems in a Chinese subtropical eutrophic bay. Marine Ecology Progress Series, 446, 73-89.

JUDD, A. D., BACKHAUS, T. \& GOODSIR, F. 2015. An effective set of principles for practical implementation of marine cumulative effects assessment. Environmental Science \& Policy, 54, 254-262.

KAMERMANS, P., MALTA, E.-J., VERSCHUURE, J. M., SCHRIJVERS, L., LENTZ, L. F. \& LIEN, A. T. A. 2002. Effect of grazing by isopods and amphipods on growth of $<\mathrm{i}>\mathrm{Ulva}</ \mathrm{i}>\mathrm{spp}$. (Chlorophyta). Aquatic Ecology : A Multidisciplinary Journal Relating to Processes and Structures at Different Organizational Levels, 36, 425-433.

KARMAN, C., SLIJKERMAN, D. M. E. \& TAMIS, J. 2009. Disturbance-effect relationships applied in an integral ecological risk analysis for the human use of the North Sea. [S.I.]: Wageningen IMARES.

KINGSFORD, M. J. 1993. Biotic and Abiotic Structure in the Pelagic Environment - Importance to Small Fishes. Bulletin of Marine Science, 53, 393-415.

KNIGHTS, A. M., PIET, G. J., JONGBLOED, R. H., TAMIS, J. E., WHITE, L., AKOGLU, E., BOICENCO, L., CHURILOVA, T., KRYVENKO, O., FLEMING-LEHTINEN, V., LEPPANEN, J. M., GALIL, B. S., GOODSIR, F., GOREN, M., MARGONSKI, P., MONCHEVA, S., OGUZ, T., PAPADOPOULOU, K. N., SETALA, O., SMITH, C. J., STEFANOVA, K., TIMOFTE, F. \& ROBINSON, L. A. 2015. An exposure-effect approach for evaluating ecosystem-wide risks from human activities. Ices Journal of Marine Science, 72, 1105-1115. 
KOOL, J. \& BERNARD, M. S. 2019. Remote monitoring in marine production systems. Wageningen: Wageningen University \& Research.

KÜHN, S., FRANEKER, J. A. V., O'DONOGHUE, A. M., SWIERS, A., STARKENBURG, M., WERVEN, B. V., FOEKEMA, E., HERMSEN, E., EGELKRAUT-HOLTUS, M. \& LINDEBOOM, H. 2020. Details of plastic ingestion and fibre contamination in North Sea fishes. Environmental Pollution 257 (2020); ISSN: 0269-7491 [Online]. Available: https://edepot.wur.nl/507361.

LAGERVELD, S., JONGE POERINK, B. \& VRIES, P. D. 2015. Monitoring bat activity at the Dutch EEZ in 2014. IJmuiden: IMARES Wageningen UR.

LAVERS, J. L., HUTTON, I. \& BOND, A. L. 2019. Clinical Pathology of Plastic Ingestion in Marine Birds and Relationships with Blood Chemistry. Environmental Science \& Technology, 53, 9224.

LUBSCH, A., BURGGRAAF, D., LANSBERGEN, R., LUBSCH, A., BURGGRAAF, D. \& LANSBERGEN, R. 2020. Feasibility study on remote estimation of biomass in a seaweed cultivation farm applying sonar : technical report. Yerseke: Wageningen Marine Research.

LUBSCH, A., LANSBERGEN, R., LUBSCH, A. \& LANSBERGEN, R. 2021. Baited camera to identify macro-fauna species and their abundance in close proximity to seaweed farms : technical report. Yerseke: Wageningen Marine Research.

MAO, X., AUGYTE, S., HUANG, M., HARE, M. P., BAILEY, D., UMANZOR, S., MARTY-RIVERA, M., ROBBINS, K. R., YARISH, C., LINDELL, S. \& JANNINK, J.-L. 2020. Population Genetics of Sugar Kelp Throughout the Northeastern United States Using Genome-Wide Markers. Frontiers in Marine Science, 7.

MARINHO, G. S., ANGELIDAKI, I., HOLDT, S. L. \& BIRKELAND, M. J. 2015. Commercial cultivation and bioremediation potential of sugar kelp, Saccharina latissima, in Danish waters. Journal of Applied Phycology, 27, 1963-1973.

MCKINDSEY, C. W., ARCHAMBAULT, P., CALLIER, M. D. \& OLIVIER, F. 2011. Influence of suspended and offbottom mussel culture on the sea bottom and benthic habitats: a review. Canadian Journal of Zoology-Revue Canadienne De Zoologie, 89, 622-646.

MORRISEY, D. J., COLE, R. G., DAVEY, N. K., HANDLEY, S. J., BRADLEY, A., BROWN, S. N. \& MADARASZ, A. L. 2006. Abundance and diversity of fish on mussel farms in New Zealand. Aquaculture, 252, 277288.

NAGASATO, C., KAWAMOTO, H., TOMIOKA, T., TSUYUZAKI, S., KOSUGI, C., KATO, T. \& MOTOMURA, T. 2020. Quantification of laminarialean zoospores in seawater by real-time PCR. Phycological Research, 68, 57-62.

NELMS, S. E., BARNETT, J., BROWNLOW, A., DAVISON, N. J., DEAVILLE, R., GALLOWAY, T. S., LINDEQUE, P. K., SANTILLO, D. \& GODLEY, B. J. 2019. Microplastics in marine mammals stranded around the British coast: ubiquitous but transitory? Scientific Reports, 9, 1-8.

ODEMM. Options for Delivering Ecosystem-Based Marine Management [Online]. Available: https://odemm.com/ [Accessed 01/12/2019 2019].

PETEIRO, C. \& FREIRE, A. O. 2011. Offshore cultivation methods affects blade features of the edible seaweed Saccharina latissima in a bay of Galicia, Northwest Spain. Russian Journal of Marine Biology, 37, 319-323.

PIET, G., BOON, A., JONGBLOED, R., VAN DER MEULEN, M., TAMIS, J., TEAL, L. \& TJALLING VAN DER WAL, J. 2017a. Cumulative Effects Assessment: Proof of Concept Marine mammals. Den helder: Wageningen Marine research.

PIET, G., CULHANE, F., JONGBLOED, R., ROBINSON, L., RUMES, B. \& TAMIS, J. 2019. An integrated riskbased assessment of the North Sea to guide ecosystem-based management. Science of the Total Environment, 654, 694-704.

PIET, G. J., JONGBLOED, R. H., KNIGHTS, A. M., TAMIS, J. E., PAIJMANS, A. J., VAN DER SLUIS, M. T., DE VRIES, P. \& ROBINSON, L. A. 2015. Evaluation of ecosystem-based marine management strategies based on risk assessment. Biological Conservation, 186, 158-166.

PIET, G. J., KNIGHTS, A. M., JONGBLOED, R. H., TAMIS, J. E., DE VRIES, P. \& ROBINSON, L. A. $2017 \mathrm{~b}$. Ecological risk assessments to guide decision-making: Methodology matters. Environmental Science \& Policy, 68, 1-9.

ROBINSON, R. A., MORRISON, C. A. \& BAILLIE, S. R. 2014. Integrating demographic data: towards a framework for monitoring wildlife populations at large spatial scales. Methods in Ecology and Evolution, 5, 1361-1372.

RÖCKMANN, C., STUIVER, M., BURG, S. V. D., ZANUTTIGH, B., ZAGONARI, F., AIROLDI, L., ANGELELLI, E., SUFFREDINI, R., FRANCESCHI, G., BELLOTTI, G., SCHOUTEN, J. J., SÖDERQVIST, T., GARCÃO, R., GUANCHE GARCIA, R., SARMIENTO MARTÍNEZ, J., PETERSEN, O. S. \& AHRENSBERG, N. A. 2015. MERMAID : mermaidproject.eu. [IJmuiden]: IMARES Wageningen UR.

RUSSELL, D. J. F., BRASSEUR, S. M. J. M., THOMPSON, D., HASTIE, G. D., JANIK, V. M., AARTS, G., MCCLINTOCK, B. T., MATTHIOPOULOS, J., MOSS, S. E. W. \& MCCONNELL, B. 2014. Marine mammals trace anthropogenic structures at sea. Current Biology, 24, R638-R639.

SAPEA, S. A. F. P. B. E. A. 2019. A Scientific Perspective on Microplastics 
in Nature and Society. Berlin: SAPAE.

STELZENMULLER, V., FOCK, H. O., GIMPEL, A., RAMBO, H., DIEKMANN, R., PROBST, W. N., CALLIES, U., BOCKELMANN, F., NEUMANN, H. \& KRONCKE, I. 2015. Quantitative environmental risk assessments in the context of marine spatial management: current approaches and some perspectives. Ices Journal of Marine Science, 72, 1022-1042.

STOWELL, D. \& SUEUR, J. 2020. Ecoacoustics: acoustic sensing for biodiversity monitoring at scale. Remote Sensing in Ecology and Conservation, 6, 217-219.

TAMIS, J., JONGBLOED, R., PIET, G. \& JAK, R. 2021. Developing an Environmental Impact Assessment for Floating Island Applications. Frontiers in Marine Science, 8, 664055.

TONK, L., BERNARD, M. S., JANSEN, H. M., TONK, L., BERNARD, M. S. \& JANSEN, H. M. 2018. The use of video-techniques for monitoring and quantification of mobile fauna in marine cultivation systems. Yerseke: Wageningen Marine Research.

TONK, L. \& JANSEN, H. M. 2019. Notitie: Potentiële effecten van duurzame zeewierproductie op de biodiversiteit in de Noordzee. Yerseke: Wageningen Marine Research (WMR).

TONK, L., WITBAARD, R., VAN DALEN, P. \& KAMERMANS, P. 2019. Applicability of the valve gape monitor to assist with oyster bed (Ostrea edulis) restoration projects. Yerseke: Wageningen University \& Research.

TROPOS 2014. D6.2 Report on Environmental Impact Assessment and Mitigation Strategies. Bremen: University of Bremen/MARUM.

VAN DEN HEUVEL-GREVE, M. J., VAN DEN BRINK, A. M., GLORIUS, S. T., DE GROOT, G. A., LAROS, I., RENAUD, P. E., PETTERSEN, R., WĘSŁAWSKI, J. M., KUKLINSKI, P. \& MURK, A. J. 2021. Early detection of marine non-indigenous species on Svalbard by DNA metabarcoding of sediment. Polar Biology, 44, 653-665.

VAN DER MOLEN, J., RUARDIJ, P., MOONEY, K., KERRISON, P., O'CONNOR, N. E., GORMAN, E., TIMMERMANS, K., WRIGHT, S., KELLY, M., HUGHES, A. D. \& CAPUZZO, E. 2018. Modelling potential production of macroalgae farms in UK and Dutch coastal waters. Biogeosciences, 15, 1123-1147.

VAN DUREN, L., POELMAN, M., JANSEN, H. M. \& TIMMERMANS, K. 2019. Een realistische kijk op zeewierproductie in de Noordzee. Yerseke: Wageningen Marine Research.

VISCH, W., KONONETS, M., HALL, P. O. J., NYLUND, G. M. \& PAVIA, H. 2020. Environmental impact of kelp (Saccharina latissima) aquaculture. Marine Pollution Bulletin, 155.

WAITE, H. R., DONNELLY, M. J. \& WALTERS, L. J. 2018. Quantity and types of microplastics in the organic tissues of the eastern oyster Crassostrea virginica and Atlantic mud crab Panopeus herbstii from a Florida estuary. Marine pollution bulletin, 129, 179-185.

WILLSTEED, E., GILL, A. B., BIRCHENOUGH, S. N. R. \& JUDE, S. 2017. Assessing the cumulative environmental effects of marine renewable energy developments: Establishing common ground. Science of the Total Environment, 577, 19-32.

WOOD, D., CAPUZZO, E., KIRBY, D., MOONEY-MCAULEY, K. \& KERRISON, P. 2017. UK macroalgae aquaculture: What are the key environmental and licensing considerations? Marine Policy, 83, 2939.

WU, C., JIAO, W., YANJIAN, Y., ZHUANG, L., TING, G., YONGCHUAN, L. \& XIAOTONG, W. 2015. Adult Pacific Oyster (Crassostrea gigas) May Have Light Sensitivity. PLoS ONE [Online], 10.

XIAODI, S., LAURA, S. \& XIAN JUN, L. 2020. Sensors, Biosensors, and Analytical Technologies for Aquaculture Water Quality. Research [Online]. 


\section{Justification}

Report C069/21

Project Number: 4318300156

The scientific quality of this report has been peer reviewed by a colleague scientist and a member of the Management Team of Wageningen Marine Research

Approved: $\quad$ R.A. Lansbergen MSc.

Researcher

Signature:

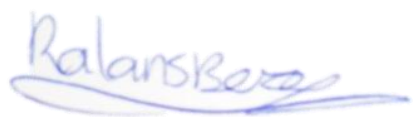

Date:

14-09-2021

Approved: Drs. J.J. Riensema

MT-lid bedrijfsvoering

Signature:

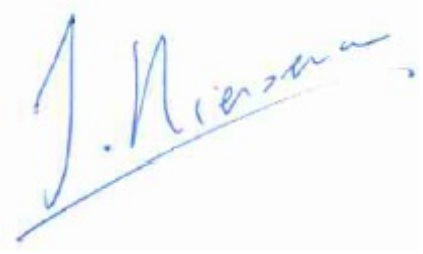

Date:

14-09-2021 


\section{Annex 1 Activity-pressure matrix}

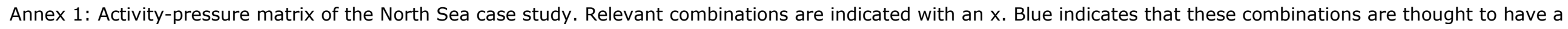
smaller impact but are still taken into account.

\begin{tabular}{|c|c|c|c|c|c|c|c|c|c|c|c|c|c|c|c|c|c|c|c|c|c|c|c|c|c|c|c|c|}
\hline & Pressure & & & & & $\underline{n}$ & $\frac{\tilde{c}}{0}$ & & & & & & & & & & & & & & & & & & & & & \\
\hline Activity & & 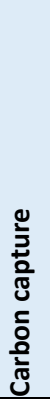 & 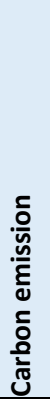 & 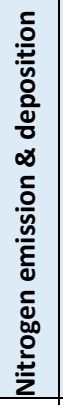 & 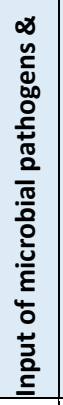 & 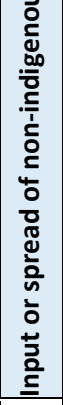 & 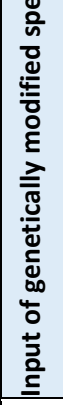 & 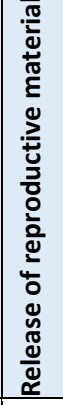 & 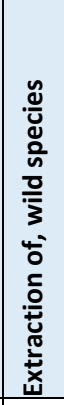 & 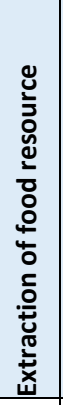 & 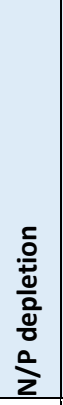 & 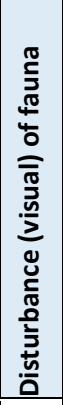 & 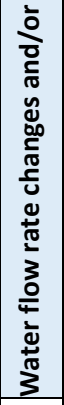 & 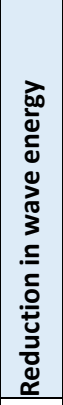 & 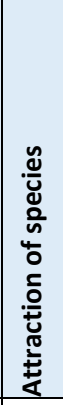 & 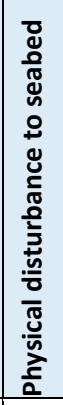 & 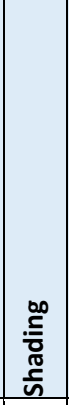 & 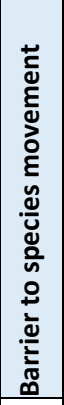 & 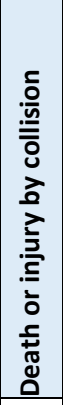 & 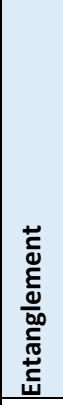 & 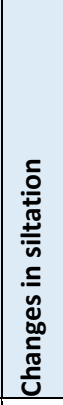 & 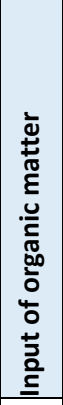 & 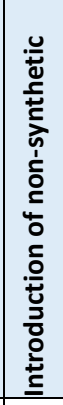 & 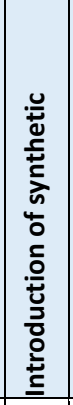 & 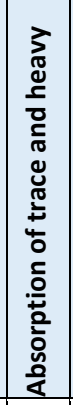 & 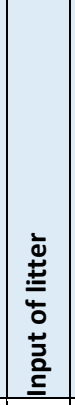 & 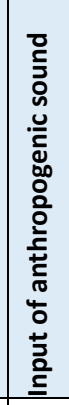 & 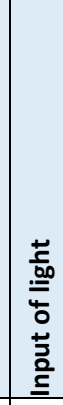 \\
\hline Instal: shipping & & & $\mathrm{x}$ & $x$ & $x$ & $x$ & & & & & & $x$ & & & & & & & $x$ & & & & $x$ & & & & $\mathrm{x}$ & $\mathrm{x}$ \\
\hline Instal: deployment longlines, buoys and mooring & & & $\mathrm{x}$ & $x$ & $x$ & & & & $\mathrm{x}$ & & & $\mathrm{x}$ & & & & $\mathrm{x}$ & & & & $\mathrm{x}$ & $\mathrm{x}$ & & $\mathrm{x}$ & & & $x$ & $\mathrm{x}$ & \\
\hline Instal: manual labour & & & & & & & & & & & & & & & & & & & & & & & & & & $x$ & & \\
\hline Op - inoculation: shipping & & & $\mathrm{x}$ & $x$ & $x$ & $x$ & & & & & & & & & & & & & $x$ & & & & $x$ & & & & $x$ & $x$ \\
\hline Op - inoculation: deployment of the droppers & & & $\mathrm{x}$ & $x$ & $\mathrm{x}$ & $\mathrm{x}$ & $\mathrm{x}$ & & & & & $\mathrm{x}$ & & & & & & & & & & $\mathrm{x}$ & $\mathrm{x}$ & & & $x$ & $\mathrm{x}$ & \\
\hline Op - inoculation: manual labour & & & & & & & & & & & & & & & & & & & & & & & & & & $x$ & & \\
\hline Op - cultivation: early growth phase & & $\mathrm{x}$ & & & $x$ & $\mathrm{x}$ & $\mathrm{x}$ & $\mathrm{x}$ & & & $x$ & $\mathrm{x}$ & $\mathrm{x}$ & $\mathrm{x}$ & $\mathrm{x}$ & & $x$ & $\mathrm{x}$ & & $\mathrm{x}$ & $\mathrm{x}$ & $\mathrm{x}$ & & & $\mathrm{x}$ & $x$ & & $\mathrm{x}$ \\
\hline Op - cultivation: final growth phase & & $\mathrm{x}$ & & & $x$ & $x$ & $x$ & $\mathrm{x}$ & & & $x$ & $\mathrm{x}$ & $\mathrm{x}$ & $\mathrm{x}$ & $x$ & & $x$ & $\mathrm{x}$ & & $\mathrm{x}$ & $\mathrm{x}$ & $\mathrm{x}$ & & & $\mathrm{x}$ & $x$ & & $x$ \\
\hline Op - cultivation: manual labour/maintenance & & & & & & & & & & & & & & & & & & & & & & & & & & $x$ & $\mathrm{x}$ & \\
\hline Op - cultivation: monitoring & & & $\mathrm{x}$ & $x$ & & & & & & & & & & & & & & & & & & & & & & & & \\
\hline Op - cultivation: shipping & & & $\mathrm{x}$ & $\mathrm{x}$ & $\mathrm{x}$ & $\mathrm{x}$ & & & & & & $\mathrm{x}$ & & & & & & & $\mathrm{x}$ & & & & $x$ & & & & $\mathrm{x}$ & $\mathrm{x}$ \\
\hline Op - harvest: mechanical harvest & & & $\mathrm{x}$ & $x$ & & & $x$ & $\mathrm{x}$ & $\mathrm{x}$ & $x$ & & $x$ & & & $\mathrm{x}$ & & & & $x$ & & & $\mathrm{x}$ & & & & $x$ & $x$ & \\
\hline Op - harvest: manual labour & & & & & & & & & & & & & & & & & & & & & & & & & & $x$ & & \\
\hline Op - harvest: shipping & & & $\mathrm{x}$ & $x$ & $x$ & $x$ & & & & & & & & & & & & & $x$ & & & & $x$ & & & & $x$ & $x$ \\
\hline Decom: retrieval of longlines, buoys and mooring & & & $\mathrm{x}$ & $x$ & & $\mathrm{x}$ & & & $\mathrm{x}$ & & & & & & & $\mathrm{x}$ & & & & $x$ & & $\mathrm{x}$ & $\mathrm{x}$ & & & $x$ & $\mathrm{x}$ & \\
\hline Decom: manual labour & & & & & & & & & & & & & & & & & & & & & & & & & & $x$ & & \\
\hline Decom: shipping & & & $x$ & $x$ & $x$ & $x$ & & & & & & & & & & & & & $x$ & & & & $x$ & & & & $x$ & $x$ \\
\hline
\end{tabular}




\section{Annex 2 Ecosystem component-pressure matrix}

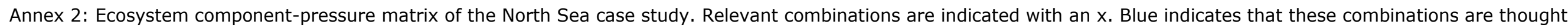
to have a smaller impact but are still taken into account.

\begin{tabular}{|c|c|c|c|c|c|c|c|c|c|c|c|c|c|c|c|c|c|c|c|c|c|c|c|c|c|c|c|c|}
\hline Ecosystem component & Pressure & 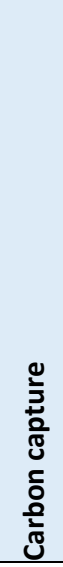 & 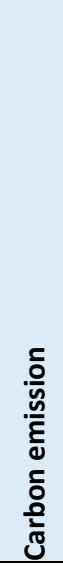 & 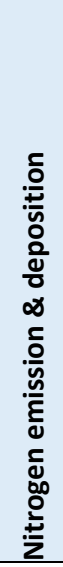 & 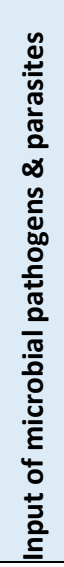 & 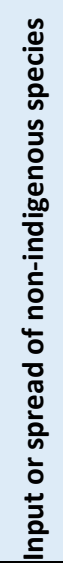 & 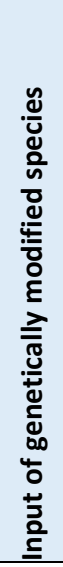 & 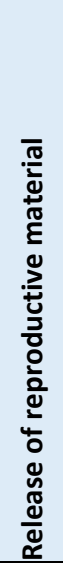 & 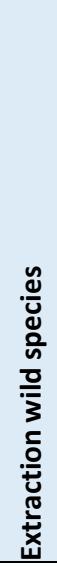 & 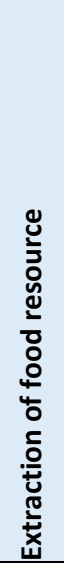 & $\begin{array}{l}\frac{0}{0} \\
\frac{0}{0} \\
\frac{0}{0} \\
\frac{0}{0} \\
0 \\
z\end{array}$ & 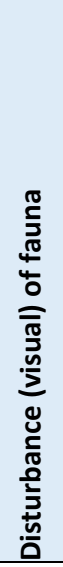 & 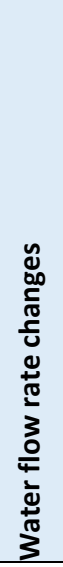 & 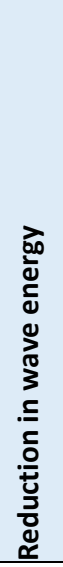 & 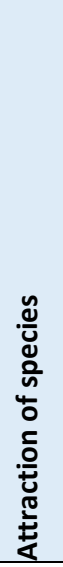 & 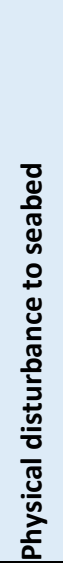 & 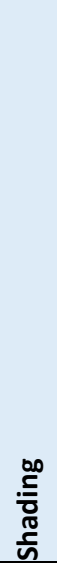 & 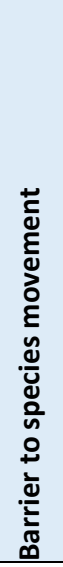 & 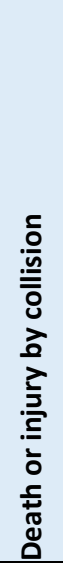 & 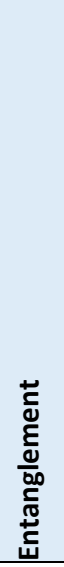 & 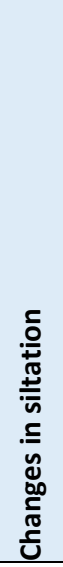 & 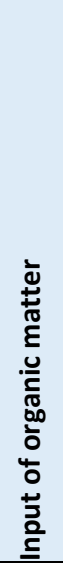 & 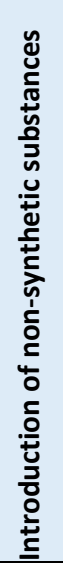 & 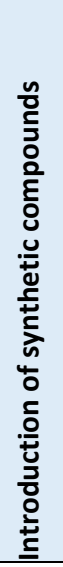 & 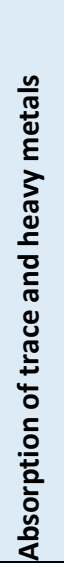 & 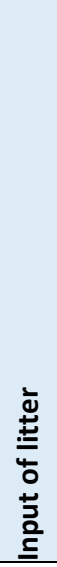 & 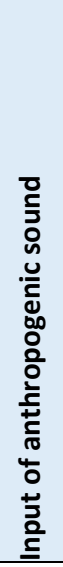 & 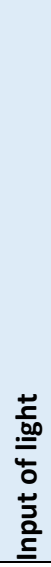 \\
\hline \multicolumn{2}{|l|}{ Plankton } & $\mathrm{x}$ & $\mathrm{x}$ & & & $x$ & & & & & $\mathrm{x}$ & & & $\mathrm{x}$ & & & $\mathrm{x}$ & & & & $\mathrm{x}$ & & $x$ & $\mathrm{x}$ & $\mathrm{x}$ & & & $\mathrm{x}$ \\
\hline \multicolumn{2}{|l|}{ Seaweed \& seagrass } & $\mathrm{x}$ & $\mathrm{x}$ & & $\mathrm{x}$ & $x$ & $\mathrm{x}$ & $x$ & & & $\mathrm{x}$ & & & & & & $\mathrm{x}$ & & & & & $x$ & $\mathrm{x}$ & $\mathrm{x}$ & $\mathrm{x}$ & & & \\
\hline \multicolumn{2}{|l|}{ Epiphytes \& epibionts } & $x$ & $x$ & & $x$ & $x$ & & & $\mathrm{x}$ & $\mathrm{x}$ & $\mathrm{x}$ & & & & $\mathrm{x}$ & & $\mathrm{x}$ & & & & & & $\mathrm{x}$ & $\mathrm{x}$ & $\mathrm{x}$ & & & \\
\hline \multicolumn{2}{|l|}{ Benthos - on bottom } & & & & & $x$ & & & & & & & & & & $x$ & & & & & $x$ & $\mathrm{x}$ & $x$ & $\mathrm{x}$ & $\mathrm{x}$ & & $\mathrm{x}$ & \\
\hline \multicolumn{2}{|l|}{ Benthos - off bottom } & & & & & $x$ & & & $x$ & $\mathrm{x}$ & & & & & $\mathrm{x}$ & & & & & & & & $\mathrm{x}$ & $x$ & $x$ & & $\mathrm{x}$ & $\mathrm{x}$ \\
\hline \multicolumn{2}{|c|}{ Fish - Adult pelagic \& demersal } & & & & & & & & & $x$ & & & & & $\mathrm{x}$ & & & $\mathrm{x}$ & & & & & $\mathrm{x}$ & $\mathrm{x}$ & $\mathrm{x}$ & $\mathrm{x}$ & $\mathrm{x}$ & $\mathrm{x}$ \\
\hline \multicolumn{2}{|l|}{ Fish - Juvenile fish } & & & & & & & & $x$ & $\mathrm{x}$ & & & & & $\mathrm{x}$ & & & $\mathrm{x}$ & & & & & $\mathrm{x}$ & $\mathrm{x}$ & $\mathrm{x}$ & & $\mathrm{x}$ & $\mathrm{x}$ \\
\hline \multicolumn{2}{|l|}{ Avial animals - Seabirds } & & & & & & & & & $x$ & & $\mathrm{x}$ & & & $\mathrm{x}$ & & & & & $\mathrm{x}$ & & & $\mathrm{x}$ & & & $\mathrm{x}$ & $\mathrm{x}$ & $\mathrm{x}$ \\
\hline \multicolumn{2}{|c|}{ Avial animals - Migratory birds } & & & & & & & & & $x$ & & $\mathrm{x}$ & & & $x$ & & & & & & & & $x$ & & & $\mathrm{x}$ & $x$ & $\mathrm{x}$ \\
\hline \multicolumn{2}{|l|}{ Avial animals - Bats } & & & & & & & & & & & $\mathrm{x}$ & & & & & & & & & & & & & & & $\mathrm{x}$ & $\mathrm{x}$ \\
\hline \multicolumn{2}{|l|}{ Marine mammals } & & & & & & & & & $\mathrm{x}$ & & $\mathrm{x}$ & & & $\mathrm{x}$ & & & $x$ & $\mathrm{x}$ & $\mathrm{x}$ & & & $x$ & & & $\mathrm{x}$ & $\mathrm{x}$ & $\mathrm{x}$ \\
\hline \multicolumn{2}{|l|}{ Hard substrate } & & & & & & & & & & & & & & & $\mathrm{x}$ & & & & & & & $\mathrm{x}$ & $\mathrm{x}$ & & $\mathrm{x}$ & & \\
\hline \multicolumn{2}{|l|}{ Soft sediment } & & & & & & & & & & & & $\mathrm{x}$ & $\mathrm{x}$ & & $\mathrm{x}$ & & & & & $x$ & $\mathrm{x}$ & $\mathrm{x}$ & $\mathrm{x}$ & $\mathrm{x}$ & $\mathrm{x}$ & & \\
\hline \multicolumn{2}{|l|}{ Water column } & $x$ & $x$ & & & & & & & & $\mathrm{x}$ & & & & & & & & & & $x$ & & $x$ & $\mathrm{x}$ & $\mathrm{x}$ & $\mathrm{x}$ & & \\
\hline \multicolumn{2}{|l|}{ Terrestrial } & & & $x$ & & & & & & & & & & & & & & & & & & & $x$ & $x$ & $x$ & $\mathrm{x}$ & & \\
\hline
\end{tabular}




\section{Annex 3 Spatial extent}

Annex 3: Spatial extent of each sub activity and ecosystem component combination.

\begin{tabular}{|c|c|c|c|c|c|c|c|c|c|c|c|c|c|c|c|}
\hline Sub activities & Plankton & $\begin{array}{l}\text { Seaweed } \\
\& \\
\text { seagrass }\end{array}$ & $\begin{array}{l}\text { Epiphytes } \\
\& \\
\text { epibionts }\end{array}$ & $\begin{array}{l}\text { Benthos } \\
-\quad \text { on } \\
\text { bottom }\end{array}$ & $\begin{array}{l}\text { Benthos } \\
-\quad \text { off } \\
\text { bottom }\end{array}$ & $\begin{array}{l}\text { Fish - } \\
\text { Adult } \\
\text { pelagic \& } \\
\text { demersal }\end{array}$ & $\begin{array}{l}\text { Fish - } \\
\text { Juvenile } \\
\text { fish }\end{array}$ & $\begin{array}{l}\text { Avial } \\
\text { animals - } \\
\text { Seabirds }\end{array}$ & $\begin{array}{l}\text { Avial } \\
\text { animals - } \\
\text { Migratory } \\
\text { birds }\end{array}$ & $\begin{array}{l}\text { Avial } \\
\text { animals } \\
\text { - Bats }\end{array}$ & $\begin{array}{l}\text { Marine } \\
\text { mammals }\end{array}$ & $\begin{array}{l}\text { Hard } \\
\text { substrate }\end{array}$ & $\begin{array}{l}\text { Soft } \\
\text { sediment }\end{array}$ & $\begin{array}{l}\text { Water } \\
\text { column }\end{array}$ & Terrestrial \\
\hline $\begin{array}{l}\text { Deployment cultivation systems, } \\
\text { buoys and mooring (trampling, } \\
\text { interaction with seafloor) }\end{array}$ & 0.833 & 0.005 & 0.005 & 0.833 & 0.103 & 0.833 & 0.833 & 0.833 & 0.833 & 0.833 & 0.833 & 0.042 & 0.792 & 0.833 & 0.016 \\
\hline Shipping* & 55.400 & 0.326 & 0.326 & 55.400 & 6.833 & 55.400 & 55.400 & 55.400 & 55.400 & 55.400 & 55.400 & 2.770 & 52.630 & 55.400 & 0.016 \\
\hline Manual labour & 0.833 & 0.005 & 0.005 & 0.833 & 0.103 & 0.833 & 0.833 & 0.833 & 0.833 & 0.833 & 0.833 & 0.042 & 0.792 & 0.833 & 0.016 \\
\hline $\begin{array}{l}\text { Deployment of the inoculation } \\
\text { system }\end{array}$ & 0.833 & 0.005 & 0.005 & 0.833 & 0.103 & 0.833 & 0.833 & 0.833 & 0.833 & 0.833 & 0.833 & 0.042 & 0.792 & 0.833 & 0.016 \\
\hline Shipping* & 1.108 & 0.007 & 0.007 & 1.108 & 0.137 & 1.108 & 1.108 & 1.108 & 1.108 & 1.108 & 1.108 & 0.055 & 1.053 & 1.108 & 0.016 \\
\hline Manual labour & 0.833 & 0.005 & 0.005 & 0.833 & 0.103 & 0.833 & 0.833 & 0.833 & 0.833 & 0.833 & 0.833 & 0.042 & 0.792 & 0.833 & 0.016 \\
\hline Early growth & 0.833 & 0.005 & 0.005 & 0.833 & 0.103 & 0.833 & 0.833 & 0.833 & 0.833 & 0.833 & 0.833 & 0.042 & 0.792 & 0.833 & 0.016 \\
\hline Final growth & 0.833 & 0.005 & 0.005 & 0.833 & 0.103 & 0.833 & 0.833 & 0.833 & 0.833 & 0.833 & 0.833 & 0.042 & 0.792 & 0.833 & 0.016 \\
\hline Maintenance/manual labour & 0.833 & 0.005 & 0.005 & 0.833 & 0.103 & 0.833 & 0.833 & 0.833 & 0.833 & 0.833 & 0.833 & 0.042 & 0.792 & 0.833 & 0.016 \\
\hline Shipping* & 6.648 & 0.039 & 0.039 & 6.648 & 0.820 & 6.648 & 6.648 & 6.648 & 6.648 & 6.648 & 6.648 & 0.332 & 6.316 & 6.648 & 0.016 \\
\hline Monitoring & 0.833 & 0.005 & 0.005 & 0.833 & 0.103 & 0.833 & 0.833 & 0.833 & 0.833 & 0.833 & 0.833 & 0.042 & 0.792 & 0.833 & 0.016 \\
\hline Mechanical harvesting & 0.833 & 0.005 & 0.005 & 0.833 & 0.103 & 0.833 & 0.833 & 0.833 & 0.833 & 0.833 & 0.833 & 0.042 & 0.792 & 0.833 & 0.016 \\
\hline Manual harvesting & 0.833 & 0.005 & 0.005 & 0.833 & 0.103 & 0.833 & 0.833 & 0.833 & 0.833 & 0.833 & 0.833 & 0.042 & 0.792 & 0.833 & 0.016 \\
\hline Shipping* & 1.108 & 0.007 & 0.007 & 1.108 & 0.137 & 1.108 & 1.108 & 1.108 & 1.108 & 1.108 & 1.108 & 0.055 & 1.053 & 1.108 & 0.016 \\
\hline Manual labour & 0.833 & 0.005 & 0.005 & 0.833 & 0.103 & 0.833 & 0.833 & 0.833 & 0.833 & 0.833 & 0.833 & 0.042 & 0.792 & 0.833 & 0.016 \\
\hline $\begin{array}{l}\text { Retrieval of cultivation systems, } \\
\text { buoys and mooring (trampling, } \\
\text { interaction with seafloor) }\end{array}$ & 0.833 & 0.005 & 0.005 & 0.833 & 0.103 & 0.833 & 0.833 & 0.833 & 0.833 & 0.833 & 0.833 & 0.042 & 0.792 & 0.833 & 0.016 \\
\hline Shipping* & 55.400 & 0.326 & 0.326 & 55.400 & 6.833 & 55.400 & 55.400 & 55.400 & 55.400 & 55.400 & 55.400 & 2.770 & 52.630 & 55.400 & 0.016 \\
\hline Manual labour & 0.833 & 0.005 & 0.005 & 0.833 & 0.103 & 0.833 & 0.833 & 0.833 & 0.833 & 0.833 & 0.833 & 0.042 & 0.792 & 0.833 & 0.016 \\
\hline
\end{tabular}




\section{Annex 4 Impact Chains}

Annex 4: 631 impact chains

\begin{tabular}{|c|c|c|c|c|c|c|}
\hline Number & Specific Primary Activity & Pressure & $\begin{array}{l}\text { Ecosystem } \\
\text { Component }\end{array}$ & $\begin{array}{l}\text { Inst } \\
\text { ImR }\end{array}$ & $\begin{array}{c}\text { Long- } \\
\text { term } \\
\text { IR }\end{array}$ & $\begin{array}{l}\text { Instant } \\
\text { IR_2 }\end{array}$ \\
\hline 1 & $\begin{array}{l}\text { Op - cultivation: final growth } \\
\text { phase }\end{array}$ & Absorption of trace and heavy metals & water column & 0.000 & 27.97 & 8.16 \\
\hline 2 & $\begin{array}{l}\text { Op - cultivation: final growth } \\
\text { phase }\end{array}$ & Absorption of trace and heavy metals & plankton & 0.000 & 27.97 & 8.26 \\
\hline 3 & $\begin{array}{l}\text { Op - cultivation: early growth } \\
\text { phase }\end{array}$ & Absorption of trace and heavy metals & plankton & 0.000 & 27.97 & 8.36 \\
\hline 4 & $\begin{array}{l}\text { Op - cultivation: early growth } \\
\text { phase }\end{array}$ & Absorption of trace and heavy metals & water column & 0.000 & 27.97 & 8.36 \\
\hline 5 & $\begin{array}{l}\text { Op - cultivation: final growth } \\
\text { phase }\end{array}$ & Absorption of trace and heavy metals & hard sub & 0.004 & 30.47 & 48.94 \\
\hline 6 & $\begin{array}{l}\text { Op - cultivation: final growth } \\
\text { phase }\end{array}$ & Absorption of trace and heavy metals & benthos_off & 0.004 & 30.47 & 48.99 \\
\hline 7 & $\begin{array}{l}\text { Op - cultivation: final growth } \\
\text { phase }\end{array}$ & Absorption of trace and heavy metals & soft sed & 0.004 & 30.47 & 49.50 \\
\hline 8 & $\begin{array}{l}\text { Op - cultivation: early growth } \\
\text { phase }\end{array}$ & Absorption of trace and heavy metals & terrestrial & 0.014 & 30.47 & 49.52 \\
\hline 9 & $\begin{array}{l}\text { Op - cultivation: final growth } \\
\text { phase }\end{array}$ & Absorption of trace and heavy metals & benthos_on & 0.004 & 30.47 & 49.53 \\
\hline 10 & $\begin{array}{l}\text { Op - cultivation: final growth } \\
\text { phase }\end{array}$ & Absorption of trace and heavy metals & terrestrial & 0.004 & 30.47 & 49.53 \\
\hline 11 & $\begin{array}{l}\text { Op - cultivation: early growth } \\
\text { phase }\end{array}$ & Absorption of trace and heavy metals & hard sub & 0.014 & 30.47 & 49.54 \\
\hline 12 & $\begin{array}{l}\text { Op - cultivation: early growth } \\
\text { phase }\end{array}$ & Absorption of trace and heavy metals & benthos_off & 0.015 & 30.47 & 49.59 \\
\hline 13 & $\begin{array}{l}\text { Op - cultivation: early growth } \\
\text { phase }\end{array}$ & Absorption of trace and heavy metals & soft sed & 0.015 & 30.47 & 50.10 \\
\hline 14 & $\begin{array}{l}\text { Op - cultivation: early growth } \\
\text { phase }\end{array}$ & Absorption of trace and heavy metals & benthos_on & 0.016 & 30.47 & 50.13 \\
\hline 15 & $\begin{array}{l}\text { Op - cultivation: final growth } \\
\text { phase }\end{array}$ & Absorption of trace and heavy metals & fish_adult & 0.054 & 54.94 & 453.99 \\
\hline 16 & $\begin{array}{l}\text { Op - cultivation: final growth } \\
\text { phase }\end{array}$ & Absorption of trace and heavy metals & fish_juv & 0.054 & 54.94 & 453.99 \\
\hline 17 & $\begin{array}{l}\text { Op - cultivation: early growth } \\
\text { phase }\end{array}$ & Absorption of trace and heavy metals & fish_adult & 0.054 & 54.94 & 459.49 \\
\hline 18 & $\begin{array}{l}\text { Op - cultivation: early growth } \\
\text { phase }\end{array}$ & Absorption of trace and heavy metals & fish_juv & 0.054 & 54.94 & 459.49 \\
\hline 19 & $\begin{array}{l}\text { Op - cultivation: final growth } \\
\text { phase }\end{array}$ & Attraction of species & epiphytes \& epibionts & 0.000 & 3.50 & 0.91 \\
\hline 20 & Op - harvest: mechanical harvest & Attraction of species & epiphytes \& epibionts & 0.000 & 3.50 & 0.91 \\
\hline 21 & $\begin{array}{l}\text { Op - cultivation: final growth } \\
\text { phase }\end{array}$ & Attraction of species & benthos_off & 0.000 & 3.50 & 0.98 \\
\hline 22 & Op - harvest: mechanical harvest & Attraction of species & benthos_off & 0.000 & 3.50 & 0.98 \\
\hline 23 & $\begin{array}{l}\text { Op - cultivation: early growth } \\
\text { phase }\end{array}$ & Attraction of species & epiphytes \& epibionts & 0.000 & 3.50 & 1.51 \\
\hline 24 & $\begin{array}{l}\text { Op - cultivation: early growth } \\
\text { phase }\end{array}$ & Attraction of species & benthos_off & 0.000 & 3.50 & 1.58 \\
\hline 25 & $\begin{array}{l}\text { Op - cultivation: final growth } \\
\text { phase }\end{array}$ & Attraction of species & avial_migratory birds & 0.004 & 28.00 & 13.98 \\
\hline 26 & $\begin{array}{l}\text { Op - cultivation: final growth } \\
\text { phase }\end{array}$ & Attraction of species & avial_seabirds & 0.004 & 28.00 & 13.98 \\
\hline 27 & Op - harvest: mechanical harvest & Attraction of species & avial_migratory birds & 0.004 & 28.00 & 13.98 \\
\hline 28 & Op - harvest: mechanical harvest & Attraction of species & avial_seabirds & 0.004 & 28.00 & 13.98 \\
\hline 29 & $\begin{array}{l}\text { Op - cultivation: final growth } \\
\text { phase }\end{array}$ & Attraction of species & fish_adult & 0.004 & 28.00 & 13.98 \\
\hline 30 & $\begin{array}{l}\text { Op - cultivation: final growth } \\
\text { phase }\end{array}$ & Attraction of species & fish_juv & 0.004 & 28.00 & 13.98 \\
\hline 31 & Op - harvest: mechanical harvest & Attraction of species & fish_adult & 0.004 & 28.00 & 13.98 \\
\hline 32 & Op - harvest: mechanical harvest & Attraction of species & fish_juv & 0.004 & 28.00 & 13.98 \\
\hline 33 & $\begin{array}{l}\text { Op - cultivation: final growth } \\
\text { phase }\end{array}$ & Attraction of species & marine mammals & 0.004 & 28.00 & 13.98 \\
\hline 34 & Op - harvest: mechanical harvest & Attraction of species & marine mammals & 0.004 & 28.00 & 13.98 \\
\hline 35 & $\begin{array}{l}\text { Op - cultivation: early growth } \\
\text { phase }\end{array}$ & Attraction of species & avial_migratory birds & 0.004 & 28.00 & 19.48 \\
\hline
\end{tabular}




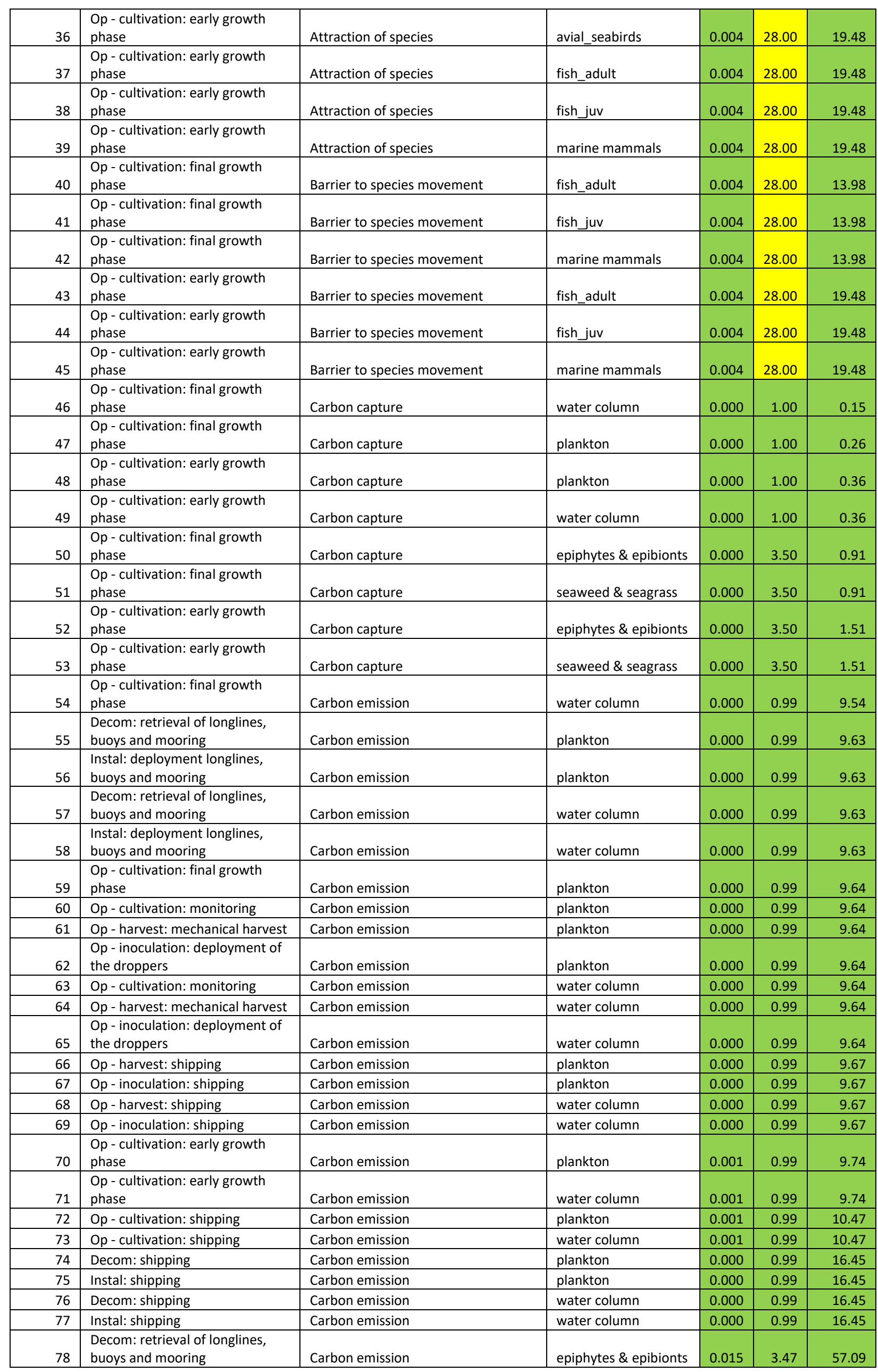




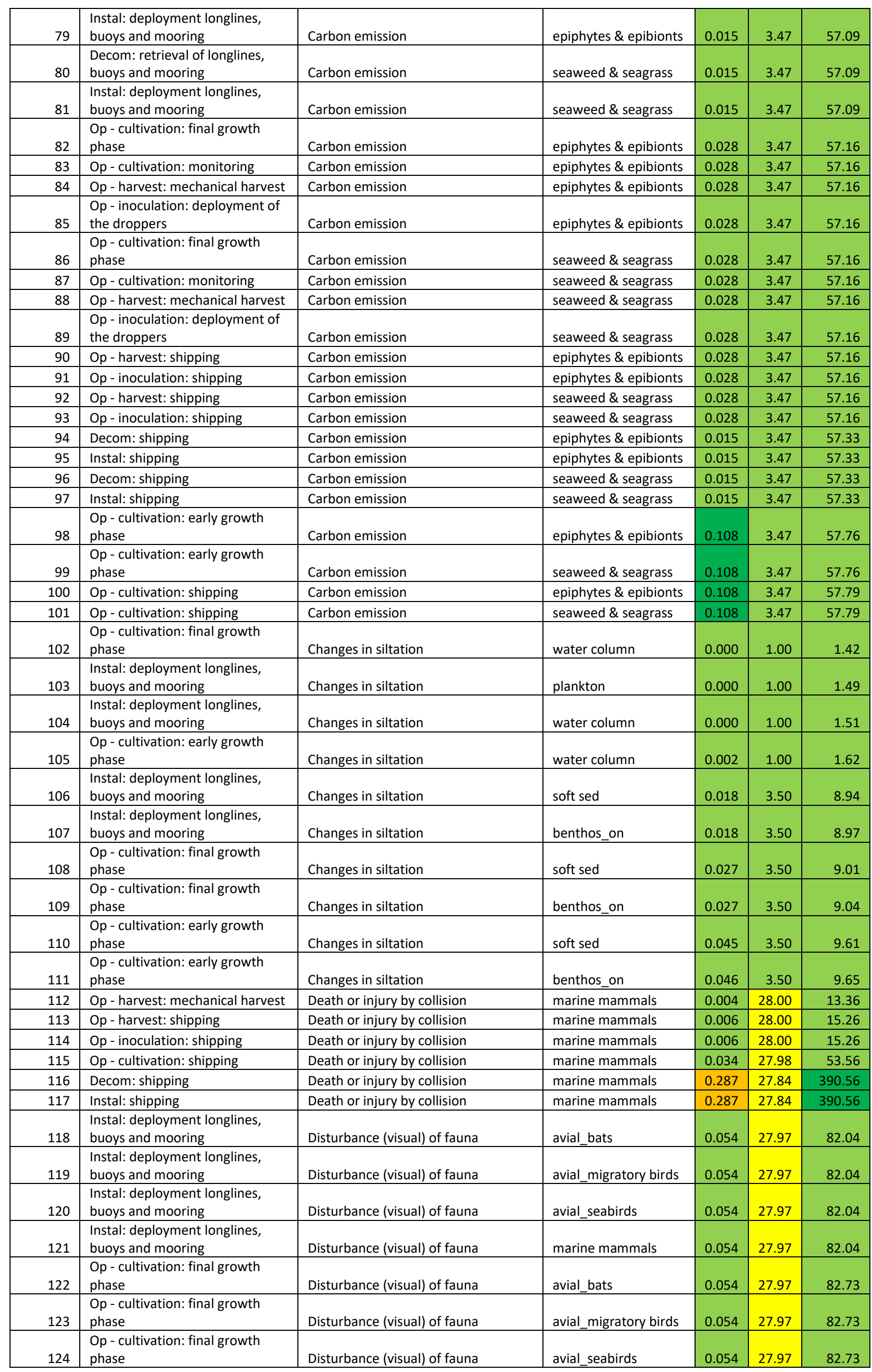




\begin{tabular}{|c|c|c|c|c|c|c|}
\hline 125 & Op - harvest: mechanical harvest & Disturbance (visual) of fauna & avial_bats & 0.054 & 27.97 & 82.73 \\
\hline 126 & Op - harvest: mechanical harvest & Disturbance (visual) of fauna & avial_migratory birds & 0.054 & 27.97 & 82.73 \\
\hline 127 & Op - harvest: mechanical harvest & Disturbance (visual) of fauna & avial_seabirds & 0.054 & 27.97 & 82.73 \\
\hline 128 & $\begin{array}{l}\text { Op - inoculation: deployment of } \\
\text { the droppers }\end{array}$ & Disturbance (visual) of fauna & avial_bats & 0.054 & 27.97 & 82.73 \\
\hline 129 & $\begin{array}{l}\text { Op - inoculation: deployment of } \\
\text { the droppers }\end{array}$ & Disturbance (visual) of fauna & avial_migratory birds & 0.054 & 27.97 & 82.73 \\
\hline 130 & $\begin{array}{l}\text { Op - inoculation: deployment of } \\
\text { the droppers }\end{array}$ & Disturbance (visual) of fauna & avial_seabirds & 0.054 & 27.97 & 82.73 \\
\hline 131 & $\begin{array}{l}\text { Op - cultivation: final growth } \\
\text { phase }\end{array}$ & Disturbance (visual) of fauna & marine mammals & 0.054 & 27.97 & 82.73 \\
\hline 132 & Op - harvest: mechanical harvest & Disturbance (visual) of fauna & marine mammals & 0.054 & 27.97 & 82.73 \\
\hline 133 & $\begin{array}{l}\text { Op - inoculation: deployment of } \\
\text { the droppers }\end{array}$ & Disturbance (visual) of fauna & marine mammals & 0.054 & 27.97 & 82.73 \\
\hline 134 & Op - harvest: shipping & Disturbance (visual) of fauna & avial_bats & 0.055 & 27.97 & 84.62 \\
\hline 135 & Op - harvest: shipping & Disturbance (visual) of fauna & avial_migratory birds & 0.055 & 27.97 & 84.62 \\
\hline 136 & Op - harvest: shipping & Disturbance (visual) of fauna & avial_seabirds & 0.055 & 27.97 & 84.62 \\
\hline 137 & Op - inoculation: shipping & Disturbance (visual) of fauna & avial_bats & 0.055 & 27.97 & 84.62 \\
\hline 138 & Op - inoculation: shipping & Disturbance (visual) of fauna & avial_migratory birds & 0.055 & 27.97 & 84.62 \\
\hline 139 & Op - inoculation: shipping & Disturbance (visual) of fauna & avial_seabirds & 0.055 & 27.97 & 84.62 \\
\hline 140 & Op - harvest: shipping & Disturbance (visual) of fauna & marine mammals & 0.055 & 27.97 & 84.62 \\
\hline 141 & Op - inoculation: shipping & Disturbance (visual) of fauna & marine mammals & 0.055 & 27.97 & 84.62 \\
\hline 142 & $\begin{array}{l}\text { Op - cultivation: early growth } \\
\text { phase }\end{array}$ & Disturbance (visual) of fauna & avial_bats & 0.054 & 27.97 & 88.23 \\
\hline 143 & $\begin{array}{l}\text { Op - cultivation: early growth } \\
\text { phase }\end{array}$ & Disturbance (visual) of fauna & avial_migratory birds & 0.054 & 27.97 & 88.23 \\
\hline 144 & $\begin{array}{l}\text { Op - cultivation: early growth } \\
\text { phase }\end{array}$ & Disturbance (visual) of fauna & avial_seabirds & 0.054 & 27.97 & 88.23 \\
\hline 145 & $\begin{array}{l}\text { Op - cultivation: early growth } \\
\text { phase }\end{array}$ & Disturbance (visual) of fauna & marine mammals & 0.054 & 27.97 & 88.23 \\
\hline 146 & Op - cultivation: shipping & Disturbance (visual) of fauna & avial_bats & 0.080 & 27.96 & 128.21 \\
\hline 147 & Op - cultivation: shipping & Disturbance (visual) of fauna & avial_migratory birds & 0.080 & 27.96 & 128.21 \\
\hline 148 & Op - cultivation: shipping & Disturbance (visual) of fauna & avial_seabirds & 0.080 & 27.96 & 128.21 \\
\hline 149 & Op - cultivation: shipping & Disturbance (visual) of fauna & marine mammals & 0.080 & 27.96 & 128.21 \\
\hline 150 & Decom: shipping & Disturbance (visual) of fauna & avial_bats & 0.299 & 27.83 & 457.20 \\
\hline 151 & Decom: shipping & Disturbance (visual) of fauna & avial_migratory birds & 0.299 & 27.83 & 457.20 \\
\hline 152 & Decom: shipping & Disturbance (visual) of fauna & avial_seabirds & 0.299 & 27.83 & 457.20 \\
\hline 153 & Instal: shipping & Disturbance (visual) of fauna & avial_bats & 0.299 & 27.83 & 457.20 \\
\hline 154 & Instal: shipping & Disturbance (visual) of fauna & avial_migratory birds & 0.299 & 27.83 & 457.20 \\
\hline 155 & Instal: shipping & Disturbance (visual) of fauna & avial_seabirds & 0.299 & 27.83 & 457.20 \\
\hline 156 & Decom: shipping & Disturbance (visual) of fauna & marine mammals & 0.299 & 27.83 & 457.20 \\
\hline 157 & Instal: shipping & Disturbance (visual) of fauna & marine mammals & 0.299 & 27.83 & 457.20 \\
\hline 158 & $\begin{array}{l}\text { Op - cultivation: early growth } \\
\text { phase }\end{array}$ & Entanglement & plankton & 0.001 & 1.00 & 0.31 \\
\hline 159 & $\begin{array}{l}\text { Op - cultivation: final growth } \\
\text { phase }\end{array}$ & Entanglement & plankton & 0.001 & 1.00 & 0.31 \\
\hline 160 & $\begin{array}{l}\text { Decom: retrieval of longlines, } \\
\text { buoys and mooring }\end{array}$ & Entanglement & avial_seabirds & 0.004 & 28.00 & 13.36 \\
\hline 161 & $\begin{array}{l}\text { Instal: deployment longlines, } \\
\text { buoys and mooring }\end{array}$ & Entanglement & avial_seabirds & 0.004 & 28.00 & 13.36 \\
\hline 162 & $\begin{array}{l}\text { Op - cultivation: early growth } \\
\text { phase }\end{array}$ & Entanglement & avial_seabirds & 0.004 & 28.00 & 13.36 \\
\hline 163 & $\begin{array}{l}\text { Op - cultivation: final growth } \\
\text { phase }\end{array}$ & Entanglement & avial_seabirds & 0.004 & 28.00 & 13.36 \\
\hline 164 & $\begin{array}{l}\text { Decom: retrieval of longlines, } \\
\text { buoys and mooring }\end{array}$ & Entanglement & marine mammals & 0.004 & 28.00 & 13.36 \\
\hline 165 & $\begin{array}{l}\text { Instal: deployment longlines, } \\
\text { buoys and mooring }\end{array}$ & Entanglement & marine mammals & 0.004 & 28.00 & 13.36 \\
\hline 166 & $\begin{array}{l}\text { Op - cultivation: early growth } \\
\text { phase }\end{array}$ & Entanglement & marine mammals & 0.004 & 28.00 & 13.36 \\
\hline 167 & $\begin{array}{l}\text { Op - cultivation: final growth } \\
\text { phase }\end{array}$ & Entanglement & marine mammals & 0.004 & 28.00 & 13.36 \\
\hline 168 & Op - harvest: mechanical harvest & Extraction of food resource & epiphytes \& epibionts & 0.000 & 3.50 & 0.95 \\
\hline 169 & Op - harvest: mechanical harvest & Extraction of food resource & benthos_off & 0.001 & 3.50 & 1.03 \\
\hline 170 & Op - harvest: mechanical harvest & Extraction of food resource & avial_migratory birds & 0.004 & 28.00 & 14.06 \\
\hline 171 & Op - harvest: mechanical harvest & Extraction of food resource & avial_seabirds & 0.004 & 28.00 & 14.06 \\
\hline 172 & Op - harvest: mechanical harvest & Extraction of food resource & fish_adult & 0.004 & 28.00 & 14.06 \\
\hline 173 & Op - harvest: mechanical harvest & Extraction of food resource & fish_juv & 0.004 & 28.00 & 14.06 \\
\hline 174 & Op - harvest: mechanical harvest & Extraction of food resource & marine mammals & 0.004 & 28.00 & 14.06 \\
\hline 175 & $\begin{array}{l}\text { Decom: retrieval of longlines, } \\
\text { buoys and mooring }\end{array}$ & $\begin{array}{l}\text { Extraction of, or mortality/injury to, } \\
\text { wild species }\end{array}$ & epiphytes \& epibionts & 0.000 & 3.50 & 0.87 \\
\hline
\end{tabular}




\begin{tabular}{|c|c|c|c|c|c|c|}
\hline 176 & $\begin{array}{l}\text { Instal: deployment longlines, } \\
\text { buoys and mooring }\end{array}$ & $\begin{array}{l}\text { Extraction of, or mortality/injury to, } \\
\text { wild species }\end{array}$ & epiphytes \& epibionts & 0.000 & 3.50 & 0.87 \\
\hline 177 & $\begin{array}{l}\text { Decom: retrieval of longlines, } \\
\text { buoys and mooring }\end{array}$ & $\begin{array}{l}\text { Extraction of, or mortality/injury to, } \\
\text { wild species }\end{array}$ & benthos_off & 0.000 & 3.50 & 0.95 \\
\hline 178 & $\begin{array}{l}\text { Instal: deployment longlines, } \\
\text { buoys and mooring }\end{array}$ & $\begin{array}{l}\text { Extraction of, or mortality/injury to, } \\
\text { wild species }\end{array}$ & benthos_off & 0.000 & 3.50 & 0.95 \\
\hline 179 & Op - harvest: mechanical harvest & $\begin{array}{l}\text { Extraction of, or mortality/injury to, } \\
\text { wild species }\end{array}$ & epiphytes \& epibionts & 0.000 & 3.50 & 0.95 \\
\hline 180 & Op - harvest: mechanical harvest & $\begin{array}{l}\text { Extraction of, or mortality/injury to, } \\
\text { wild species }\end{array}$ & benthos_off & 0.001 & 3.50 & 1.03 \\
\hline 181 & $\begin{array}{l}\text { Decom: retrieval of longlines, } \\
\text { buoys and mooring }\end{array}$ & $\begin{array}{l}\text { Extraction of, or mortality/injury to, } \\
\text { wild species }\end{array}$ & fish_juv & 0.004 & 28.00 & 13.36 \\
\hline 182 & $\begin{array}{l}\text { Instal: deployment longlines, } \\
\text { buoys and mooring }\end{array}$ & $\begin{array}{l}\text { Extraction of, or mortality/injury to, } \\
\text { wild species }\end{array}$ & fish_juv & 0.004 & 28.00 & 13.36 \\
\hline 183 & Op - harvest: mechanical harvest & $\begin{array}{l}\text { Extraction of, or mortality/injury to, } \\
\text { wild species }\end{array}$ & fish_juv & 0.004 & 28.00 & 14.06 \\
\hline 184 & $\begin{array}{l}\text { Decom: retrieval of longlines, } \\
\text { buoys and mooring }\end{array}$ & $\begin{array}{l}\text { Input of anthropogenic sound } \\
\text { (impulsive, continuous) }\end{array}$ & benthos_off & 0.002 & 3.50 & 8.40 \\
\hline 185 & $\begin{array}{l}\text { Decom: retrieval of longlines, } \\
\text { buoys and mooring }\end{array}$ & $\begin{array}{l}\text { Input of anthropogenic sound } \\
\text { (impulsive, continuous) }\end{array}$ & benthos_off & 0.002 & 3.50 & 8.40 \\
\hline 186 & $\begin{array}{l}\text { Instal: deployment longlines, } \\
\text { buoys and mooring }\end{array}$ & $\begin{array}{l}\text { Input of anthropogenic sound } \\
\text { (impulsive, continuous) }\end{array}$ & benthos_off & 0.002 & 3.50 & 8.40 \\
\hline 187 & Op - harvest: mechanical harvest & $\begin{array}{l}\text { Input of anthropogenic sound } \\
\text { (impulsive, continuous) }\end{array}$ & benthos_off & 0.004 & 3.50 & 8.48 \\
\hline 188 & $\begin{array}{l}\text { Op - inoculation: deployment of } \\
\text { the droppers }\end{array}$ & $\begin{array}{l}\text { Input of anthropogenic sound } \\
\text { (impulsive, continuous) }\end{array}$ & benthos_off & 0.004 & 3.50 & 8.48 \\
\hline 189 & Op - harvest: shipping & $\begin{array}{l}\text { Input of anthropogenic sound } \\
\text { (impulsive, continuous) }\end{array}$ & benthos_off & 0.004 & 3.50 & 8.50 \\
\hline 190 & Op - inoculation: shipping & $\begin{array}{l}\text { Input of anthropogenic sound } \\
\text { (impulsive, continuous) }\end{array}$ & benthos_off & 0.004 & 3.50 & 8.50 \\
\hline 191 & $\begin{array}{l}\text { Decom: retrieval of longlines, } \\
\text { buoys and mooring }\end{array}$ & $\begin{array}{l}\text { Input of anthropogenic sound } \\
\text { (impulsive, continuous) }\end{array}$ & benthos_on & 0.002 & 3.50 & 8.95 \\
\hline 192 & $\begin{array}{l}\text { Instal: deployment longlines, } \\
\text { buoys and mooring }\end{array}$ & $\begin{array}{l}\text { Input of anthropogenic sound } \\
\text { (impulsive, continuous) }\end{array}$ & benthos on & 0.002 & 3.50 & 8.95 \\
\hline 193 & Op - harvest: mechanical harvest & $\begin{array}{l}\text { Input of anthropogenic sound } \\
\text { (impulsive, continuous) }\end{array}$ & benthos_on & 0.004 & 3.50 & 9.03 \\
\hline 194 & $\begin{array}{l}\text { Op - inoculation: deployment of } \\
\text { the droppers }\end{array}$ & $\begin{array}{l}\text { Input of anthropogenic sound } \\
\text { (impulsive, continuous) }\end{array}$ & benthos_on & 0.004 & 3.50 & 9.03 \\
\hline 195 & $\begin{array}{l}\text { Op - cultivation: manual } \\
\text { labour/maintenance }\end{array}$ & $\begin{array}{l}\text { Input of anthropogenic sound } \\
\text { (impulsive, continuous) }\end{array}$ & benthos_off & 0.015 & 3.50 & 9.08 \\
\hline 196 & Op - harvest: shipping & $\begin{array}{l}\text { Input of anthropogenic sound } \\
\text { (impulsive, continuous) }\end{array}$ & benthos_on & 0.004 & 3.50 & 9.23 \\
\hline 197 & Op - inoculation: shipping & $\begin{array}{l}\text { Input of anthropogenic sound } \\
\text { (impulsive, continuous) }\end{array}$ & benthos_on & 0.004 & 3.50 & 9.23 \\
\hline 198 & Op - cultivation: shipping & $\begin{array}{l}\text { Input of anthropogenic sound } \\
\text { (impulsive, continuous) }\end{array}$ & benthos_off & 0.015 & 3.50 & 9.62 \\
\hline 199 & $\begin{array}{l}\text { Op - cultivation: manual } \\
\text { labour/maintenance }\end{array}$ & $\begin{array}{l}\text { Input of anthropogenic sound } \\
\text { (impulsive, continuous) }\end{array}$ & benthos_on & 0.016 & 3.50 & 9.63 \\
\hline 200 & Decom: shipping & $\begin{array}{l}\text { Input of anthropogenic sound } \\
\text { (impulsive, continuous) }\end{array}$ & benthos_off & 0.003 & 3.49 & 13.45 \\
\hline 201 & Instal: shipping & $\begin{array}{l}\text { Input of anthropogenic sound } \\
\text { (impulsive, continuous) }\end{array}$ & benthos_off & 0.003 & 3.49 & 13.45 \\
\hline 202 & Op - cultivation: shipping & $\begin{array}{l}\text { Input of anthropogenic sound } \\
\text { (impulsive, continuous) }\end{array}$ & benthos on & 0.023 & 3.49 & 13.99 \\
\hline 203 & Decom: shipping & $\begin{array}{l}\text { Input of anthropogenic sound } \\
\text { (impulsive, continuous) }\end{array}$ & benthos_on & 0.012 & 3.48 & 49.88 \\
\hline 204 & Instal: shipping & $\begin{array}{l}\text { Input of anthropogenic sound } \\
\text { (impulsive, continuous) }\end{array}$ & benthos_on & 0.012 & 3.48 & 49.88 \\
\hline 205 & $\begin{array}{l}\text { Decom: retrieval of longlines, } \\
\text { buoys and mooring }\end{array}$ & $\begin{array}{l}\text { Input of anthropogenic sound } \\
\text { (impulsive, continuous) }\end{array}$ & avial_bats & 0.054 & 27.97 & 82.04 \\
\hline 206 & $\begin{array}{l}\text { Decom: retrieval of longlines, } \\
\text { buoys and mooring }\end{array}$ & $\begin{array}{l}\text { Input of anthropogenic sound } \\
\text { (impulsive, continuous) }\end{array}$ & avial_migratory birds & 0.054 & 27.97 & 82.04 \\
\hline 207 & $\begin{array}{l}\text { Decom: retrieval of longlines, } \\
\text { buoys and mooring }\end{array}$ & $\begin{array}{l}\text { Input of anthropogenic sound } \\
\text { (impulsive, continuous) }\end{array}$ & avial_seabirds & 0.054 & 27.97 & 82.04 \\
\hline 208 & $\begin{array}{l}\text { Instal: deployment longlines, } \\
\text { buoys and mooring }\end{array}$ & $\begin{array}{l}\text { Input of anthropogenic sound } \\
\text { (impulsive, continuous) }\end{array}$ & avial_bats & 0.054 & 27.97 & 82.04 \\
\hline 209 & $\begin{array}{l}\text { Instal: deployment longlines, } \\
\text { buoys and mooring }\end{array}$ & $\begin{array}{l}\text { Input of anthropogenic sound } \\
\text { (impulsive, continuous) }\end{array}$ & avial_migratory birds & 0.054 & 27.97 & 82.04 \\
\hline 210 & $\begin{array}{l}\text { Instal: deployment longlines, } \\
\text { buoys and mooring }\end{array}$ & $\begin{array}{l}\text { Input of anthropogenic sound } \\
\text { (impulsive, continuous) }\end{array}$ & avial_seabirds & 0.054 & 27.97 & 82.04 \\
\hline 211 & $\begin{array}{l}\text { Decom: retrieval of longlines, } \\
\text { buoys and mooring }\end{array}$ & $\begin{array}{l}\text { Input of anthropogenic sound } \\
\text { (impulsive, continuous) }\end{array}$ & fish_adult & 0.054 & 27.97 & 82.04 \\
\hline 212 & $\begin{array}{l}\text { Decom: retrieval of longlines, } \\
\text { buoys and mooring }\end{array}$ & $\begin{array}{l}\text { Input of anthropogenic sound } \\
\text { (impulsive, continuous) }\end{array}$ & fish_juv & 0.054 & 27.97 & 82.04 \\
\hline
\end{tabular}




\begin{tabular}{|c|c|c|c|c|c|c|}
\hline 213 & $\begin{array}{l}\text { Instal: deployment longlines, } \\
\text { buoys and mooring }\end{array}$ & $\begin{array}{l}\text { Input of anthropogenic sound } \\
\text { (impulsive, continuous) }\end{array}$ & fish_adult & 0.054 & 27.97 & 82.04 \\
\hline 214 & $\begin{array}{l}\text { Instal: deployment longlines, } \\
\text { buoys and mooring }\end{array}$ & $\begin{array}{l}\text { Input of anthropogenic sound } \\
\text { (impulsive, continuous) }\end{array}$ & fish_juv & 0.054 & 27.97 & 82.04 \\
\hline 215 & $\begin{array}{l}\text { Decom: retrieval of longlines, } \\
\text { buoys and mooring }\end{array}$ & $\begin{array}{l}\text { Input of anthropogenic sound } \\
\text { (impulsive, continuous) }\end{array}$ & marine mammals & 0.054 & 27.97 & 82.04 \\
\hline 216 & $\begin{array}{l}\text { Instal: deployment longlines, } \\
\text { buoys and mooring }\end{array}$ & $\begin{array}{l}\text { Input of anthropogenic sound } \\
\text { (impulsive, continuous) }\end{array}$ & marine mammals & 0.054 & 27.97 & 82.04 \\
\hline 217 & Op - harvest: mechanical harvest & $\begin{array}{l}\text { Input of anthropogenic sound } \\
\text { (impulsive, continuous) }\end{array}$ & avial_bats & 0.054 & 27.97 & 82.73 \\
\hline 218 & Op - harvest: mechanical harvest & $\begin{array}{l}\text { Input of anthropogenic sound } \\
\text { (impulsive, continuous) }\end{array}$ & avial_migratory birds & 0.054 & 27.97 & 82.73 \\
\hline 219 & Op - harvest: mechanical harvest & $\begin{array}{l}\text { Input of anthropogenic sound } \\
\text { (impulsive, continuous) }\end{array}$ & avial_seabirds & 0.054 & 27.97 & 82.73 \\
\hline 220 & $\begin{array}{l}\text { Op - inoculation: deployment of } \\
\text { the droppers }\end{array}$ & $\begin{array}{l}\text { Input of anthropogenic sound } \\
\text { (impulsive, continuous) }\end{array}$ & avial bats & 0.054 & 27.97 & 82.73 \\
\hline 221 & $\begin{array}{l}\text { Op - inoculation: deployment of } \\
\text { the droppers }\end{array}$ & $\begin{array}{l}\text { Input of anthropogenic sound } \\
\text { (impulsive, continuous) }\end{array}$ & avial_migratory birds & 0.054 & 27.97 & 82.73 \\
\hline 222 & $\begin{array}{l}\text { Op - inoculation: deployment of } \\
\text { the droppers }\end{array}$ & $\begin{array}{l}\text { Input of anthropogenic sound } \\
\text { (impulsive, continuous) }\end{array}$ & avial_seabirds & 0.054 & 27.97 & 82.73 \\
\hline 223 & Op - harvest: mechanical harvest & $\begin{array}{l}\text { Input of anthropogenic sound } \\
\text { (impulsive, continuous) }\end{array}$ & fish_adult & 0.054 & 27.97 & 82.73 \\
\hline 224 & Op - harvest: mechanical harvest & $\begin{array}{l}\text { Input of anthropogenic sound } \\
\text { (impulsive, continuous) }\end{array}$ & fish_juv & 0.054 & 27.97 & 82.73 \\
\hline 225 & $\begin{array}{l}\text { Op - inoculation: deployment of } \\
\text { the droppers }\end{array}$ & $\begin{array}{l}\text { Input of anthropogenic sound } \\
\text { (impulsive, continuous) }\end{array}$ & fish_adult & 0.054 & 27.97 & 82.73 \\
\hline 226 & $\begin{array}{l}\text { Op - inoculation: deployment of } \\
\text { the droppers }\end{array}$ & $\begin{array}{l}\text { Input of anthropogenic sound } \\
\text { (impulsive, continuous) }\end{array}$ & fish_juv & 0.054 & 27.97 & 82.73 \\
\hline 227 & Op - harvest: mechanical harvest & $\begin{array}{l}\text { Input of anthropogenic sound } \\
\text { (impulsive, continuous) }\end{array}$ & marine mammals & 0.054 & 27.97 & 82.73 \\
\hline 228 & $\begin{array}{l}\text { Op - inoculation: deployment of } \\
\text { the droppers }\end{array}$ & $\begin{array}{l}\text { Input of anthropogenic sound } \\
\text { (impulsive, continuous) }\end{array}$ & marine mammals & 0.054 & 27.97 & 82.73 \\
\hline 229 & Op - harvest: shipping & $\begin{array}{l}\text { Input of anthropogenic sound } \\
\text { (impulsive, continuous) }\end{array}$ & avial bats & 0.055 & 27.97 & 84.62 \\
\hline 230 & Op - harvest: shipping & $\begin{array}{l}\text { Input of anthropogenic sound } \\
\text { (impulsive, continuous) }\end{array}$ & avial_migratory birds & 0.055 & 27.97 & 84.62 \\
\hline 231 & Op - harvest: shipping & $\begin{array}{l}\text { Input of anthropogenic sound } \\
\text { (impulsive, continuous) }\end{array}$ & avial_seabirds & 0.055 & 27.97 & 84.62 \\
\hline 232 & Op - inoculation: shipping & $\begin{array}{l}\text { Input of anthropogenic sound } \\
\text { (impulsive, continuous) }\end{array}$ & avial_bats & 0.055 & 27.97 & 84.62 \\
\hline 233 & Op - inoculation: shipping & $\begin{array}{l}\text { Input of anthropogenic sound } \\
\text { (impulsive, continuous) }\end{array}$ & avial_migratory birds & 0.055 & 27.97 & 84.62 \\
\hline 234 & Op - inoculation: shipping & $\begin{array}{l}\text { Input of anthropogenic sound } \\
\text { (impulsive, continuous) }\end{array}$ & avial_seabirds & 0.055 & 27.97 & 84.62 \\
\hline 235 & Op - harvest: shipping & $\begin{array}{l}\text { Input of anthropogenic sound } \\
\text { (impulsive, continuous) }\end{array}$ & fish_adult & 0.055 & 27.97 & 84.62 \\
\hline 236 & Op - harvest: shipping & $\begin{array}{l}\text { Input of anthropogenic sound } \\
\text { (impulsive, continuous) }\end{array}$ & fish_juv & 0.055 & 27.97 & 84.62 \\
\hline 237 & Op - inoculation: shipping & $\begin{array}{l}\text { Input of anthropogenic sound } \\
\text { (impulsive, continuous) }\end{array}$ & fish_adult & 0.055 & 27.97 & 84.62 \\
\hline 238 & Op - inoculation: shipping & $\begin{array}{l}\text { Input of anthropogenic sound } \\
\text { (impulsive, continuous) }\end{array}$ & fish_juv & 0.055 & 27.97 & 84.62 \\
\hline 239 & Op - harvest: shipping & $\begin{array}{l}\text { Input of anthropogenic sound } \\
\text { (impulsive, continuous) }\end{array}$ & marine mammals & 0.055 & 27.97 & 84.62 \\
\hline 240 & Op - inoculation: shipping & $\begin{array}{l}\text { Input of anthropogenic sound } \\
\text { (impulsive, continuous) }\end{array}$ & marine mammals & 0.055 & 27.97 & 84.62 \\
\hline 241 & $\begin{array}{l}\text { Op - cultivation: manual } \\
\text { labour/maintenance }\end{array}$ & $\begin{array}{l}\text { Input of anthropogenic sound } \\
\text { (impulsive, continuous) }\end{array}$ & avial_bats & 0.054 & 27.97 & 88.23 \\
\hline 242 & $\begin{array}{l}\text { Op - cultivation: manual } \\
\text { labour/maintenance }\end{array}$ & $\begin{array}{l}\text { Input of anthropogenic sound } \\
\text { (impulsive, continuous) }\end{array}$ & avial_migratory birds & 0.054 & 27.97 & 88.23 \\
\hline 243 & $\begin{array}{l}\text { Op - cultivation: manual } \\
\text { labour/maintenance }\end{array}$ & $\begin{array}{l}\text { Input of anthropogenic sound } \\
\text { (impulsive, continuous) }\end{array}$ & avial_seabirds & 0.054 & 27.97 & 88.23 \\
\hline 244 & $\begin{array}{l}\text { Op - cultivation: manual } \\
\text { labour/maintenance }\end{array}$ & $\begin{array}{l}\text { Input of anthropogenic sound } \\
\text { (impulsive, continuous) }\end{array}$ & fish_adult & 0.054 & 27.97 & 88.23 \\
\hline 245 & $\begin{array}{l}\text { Op - cultivation: manual } \\
\text { labour/maintenance }\end{array}$ & $\begin{array}{l}\text { Input of anthropogenic sound } \\
\text { (impulsive, continuous) }\end{array}$ & fish_juv & 0.054 & 27.97 & 88.23 \\
\hline 246 & $\begin{array}{l}\text { Op - cultivation: manual } \\
\text { labour/maintenance }\end{array}$ & $\begin{array}{l}\text { Input of anthropogenic sound } \\
\text { (impulsive, continuous) }\end{array}$ & marine mammals & 0.054 & 27.97 & 88.23 \\
\hline 247 & Op - cultivation: shipping & $\begin{array}{l}\text { Input of anthropogenic sound } \\
\text { (impulsive, continuous) }\end{array}$ & avial bats & 0.080 & 27.96 & 128.21 \\
\hline 248 & Op - cultivation: shipping & $\begin{array}{l}\text { Input of anthropogenic sound } \\
\text { (impulsive, continuous) }\end{array}$ & avial_migratory birds & 0.080 & 27.96 & 128.21 \\
\hline 249 & Op - cultivation: shipping & $\begin{array}{l}\text { Input of anthropogenic sound } \\
\text { (impulsive, continuous) }\end{array}$ & avial_seabirds & 0.080 & 27.96 & 128.21 \\
\hline
\end{tabular}




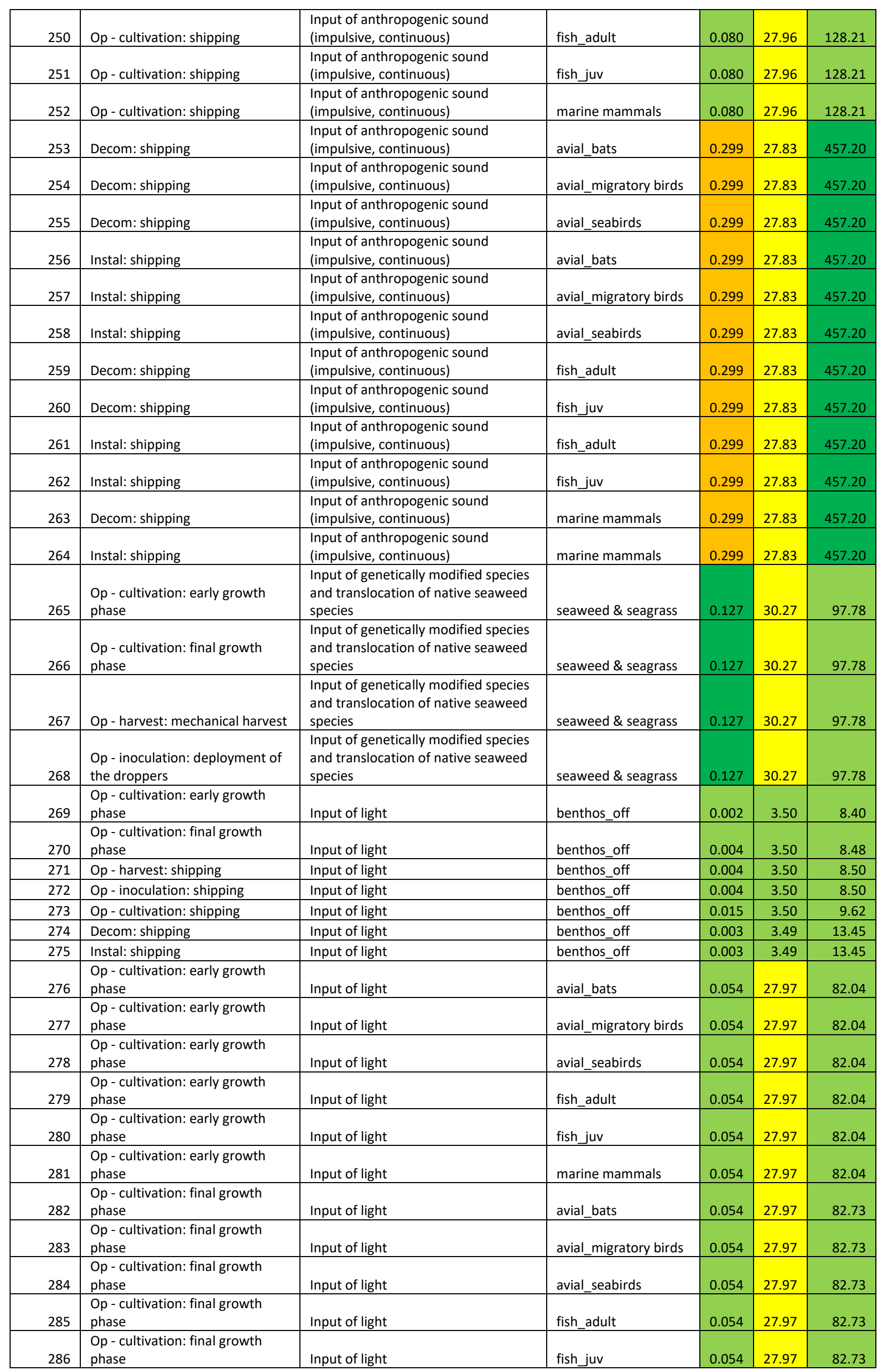




\begin{tabular}{|c|c|c|c|c|c|c|}
\hline 287 & $\begin{array}{l}\text { Op - cultivation: final growth } \\
\text { phase }\end{array}$ & Input of light & marine mammals & 0.054 & 27.97 & 82.73 \\
\hline 288 & Op - harvest: shipping & Input of light & avial_bats & 0.055 & 27.97 & 84.62 \\
\hline 289 & Op - harvest: shipping & Input of light & avial_migratory birds & 0.055 & 27.97 & 84.62 \\
\hline 290 & Op - harvest: shipping & Input of light & avial_seabirds & 0.055 & 27.97 & 84.62 \\
\hline 291 & Op - inoculation: shipping & Input of light & avial_bats & 0.055 & 27.97 & 84.62 \\
\hline 292 & Op - inoculation: shipping & Input of light & avial_migratory birds & 0.055 & 27.97 & 84.62 \\
\hline 293 & Op - inoculation: shipping & Input of light & avial_seabirds & 0.055 & 27.97 & 84.62 \\
\hline 294 & Op - harvest: shipping & Input of light & fish_adult & 0.055 & 27.97 & 84.62 \\
\hline 295 & Op - harvest: shipping & Input of light & fish_juv & 0.055 & 27.97 & 84.62 \\
\hline 296 & Op - inoculation: shipping & Input of light & fish_adult & 0.055 & 27.97 & 84.62 \\
\hline 297 & Op - inoculation: shipping & Input of light & fish_juv & 0.055 & 27.97 & 84.62 \\
\hline 298 & Op - harvest: shipping & Input of light & marine mammals & 0.055 & 27.97 & 84.62 \\
\hline 299 & Op - inoculation: shipping & Input of light & marine mammals & 0.055 & 27.97 & 84.62 \\
\hline 300 & Op - cultivation: shipping & Input of light & avial_bats & 0.080 & 27.96 & 128.21 \\
\hline 301 & Op - cultivation: shipping & Input of light & avial_migratory birds & 0.080 & 27.96 & 128.21 \\
\hline 302 & Op - cultivation: shipping & Input of light & avial_seabirds & 0.080 & 27.96 & 128.21 \\
\hline 303 & Op - cultivation: shipping & Input of light & fish_adult & 0.080 & 27.96 & 128.21 \\
\hline 304 & Op - cultivation: shipping & Input of light & fish_juv & 0.080 & 27.96 & 128.21 \\
\hline 305 & Op - cultivation: shipping & Input of light & marine mammals & 0.080 & 27.96 & 128.21 \\
\hline 306 & Decom: shipping & Input of light & avial_bats & 0.299 & 27.83 & 457.20 \\
\hline 307 & Decom: shipping & Input of light & avial_migratory birds & 0.299 & 27.83 & 457.20 \\
\hline 308 & Decom: shipping & Input of light & avial_seabirds & 0.299 & 27.83 & 457.20 \\
\hline 309 & Instal: shipping & Input of light & avial_bats & 0.299 & 27.83 & 457.20 \\
\hline 310 & Instal: shipping & Input of light & avial_migratory birds & 0.299 & 27.83 & 457.20 \\
\hline 311 & Instal: shipping & Input of light & avial_seabirds & 0.299 & 27.83 & 457.20 \\
\hline 312 & Decom: shipping & Input of light & fish_adult & 0.299 & 27.83 & 457.20 \\
\hline 313 & Decom: shipping & Input of light & fish_uv & 0.299 & 27.83 & 457.20 \\
\hline 314 & Instal: shipping & Input of light & fish_adult & 0.299 & 27.83 & 457.20 \\
\hline 315 & Instal: shipping & Input of light & fish_juv & 0.299 & 27.83 & 457.20 \\
\hline 316 & Decom: shipping & Input of light & marine mammals & 0.299 & 27.83 & 457.20 \\
\hline 317 & Instal: shipping & Input of light & marine mammals & 0.299 & 27.83 & 457.20 \\
\hline 318 & $\begin{array}{l}\text { Op - cultivation: final growth } \\
\text { phase }\end{array}$ & $\begin{array}{l}\text { Input of litter (solid waste matter, } \\
\text { including micro-sized litter) }\end{array}$ & water column & 0.000 & 27.79 & 16.28 \\
\hline 319 & Decom: manual labour & $\begin{array}{l}\text { Input of litter (solid waste matter, } \\
\text { including micro-sized litter) }\end{array}$ & water column & 0.000 & 27.79 & 16.38 \\
\hline 320 & $\begin{array}{l}\text { Decom: retrieval of longlines, } \\
\text { buoys and mooring }\end{array}$ & $\begin{array}{l}\text { Input of litter (solid waste matter, } \\
\text { including micro-sized litter) }\end{array}$ & water column & 0.000 & 27.79 & 16.38 \\
\hline 321 & $\begin{array}{l}\text { Instal: deployment longlines, } \\
\text { buoys and mooring }\end{array}$ & $\begin{array}{l}\text { Input of litter (solid waste matter, } \\
\text { including micro-sized litter) }\end{array}$ & water column & 0.000 & 27.79 & 16.38 \\
\hline 322 & Instal: manual labour & $\begin{array}{l}\text { Input of litter (solid waste matter, } \\
\text { including micro-sized litter) }\end{array}$ & water column & 0.000 & 27.79 & 16.38 \\
\hline 323 & $\begin{array}{l}\text { Op - cultivation: early growth } \\
\text { phase }\end{array}$ & $\begin{array}{l}\text { Input of litter (solid waste matter, } \\
\text { including micro-sized litter) }\end{array}$ & water column & 0.000 & 27.79 & 16.38 \\
\hline 324 & $\begin{array}{l}\text { Op - cultivation: manual } \\
\text { labour/maintenance }\end{array}$ & $\begin{array}{l}\text { Input of litter (solid waste matter, } \\
\text { including micro-sized litter) }\end{array}$ & water column & 0.000 & 27.79 & 16.38 \\
\hline 325 & Op - harvest: manual labour & $\begin{array}{l}\text { Input of litter (solid waste matter, } \\
\text { including micro-sized litter) }\end{array}$ & water column & 0.000 & 27.79 & 16.38 \\
\hline 326 & Op - harvest: mechanical harvest & $\begin{array}{l}\text { Input of litter (solid waste matter, } \\
\text { including micro-sized litter) }\end{array}$ & water column & 0.000 & 27.79 & 16.38 \\
\hline 327 & $\begin{array}{l}\text { Op - inoculation: deployment of } \\
\text { the droppers }\end{array}$ & $\begin{array}{l}\text { Input of litter (solid waste matter, } \\
\text { including micro-sized litter) }\end{array}$ & water column & 0.000 & 27.79 & 16.38 \\
\hline 328 & Op - inoculation: manual labour & $\begin{array}{l}\text { Input of litter (solid waste matter, } \\
\text { including micro-sized litter) }\end{array}$ & water column & 0.000 & 27.79 & 16.40 \\
\hline 329 & Decom: manual labour & $\begin{array}{l}\text { Input of litter (solid waste matter, } \\
\text { including micro-sized litter) }\end{array}$ & terrestrial & 0.015 & 30.27 & 97.60 \\
\hline 330 & $\begin{array}{l}\text { Decom: retrieval of longlines, } \\
\text { buoys and mooring }\end{array}$ & $\begin{array}{l}\text { Input of litter (solid waste matter, } \\
\text { including micro-sized litter) }\end{array}$ & terrestrial & 0.015 & 30.27 & 97.60 \\
\hline 331 & $\begin{array}{l}\text { Instal: deployment longlines, } \\
\text { buoys and mooring }\end{array}$ & $\begin{array}{l}\text { Input of litter (solid waste matter, } \\
\text { including micro-sized litter) }\end{array}$ & terrestrial & 0.015 & 30.27 & 97.60 \\
\hline 332 & Instal: manual labour & $\begin{array}{l}\text { Input of litter (solid waste matter, } \\
\text { including micro-sized litter) }\end{array}$ & terrestrial & 0.015 & 30.27 & 97.60 \\
\hline 333 & $\begin{array}{l}\text { Op - cultivation: early growth } \\
\text { phase }\end{array}$ & $\begin{array}{l}\text { Input of litter (solid waste matter, } \\
\text { including micro-sized litter) }\end{array}$ & terrestrial & 0.015 & 30.27 & 97.60 \\
\hline 334 & $\begin{array}{l}\text { Op - cultivation: manual } \\
\text { labour/maintenance }\end{array}$ & $\begin{array}{l}\text { Input of litter (solid waste matter, } \\
\text { including micro-sized litter) }\end{array}$ & terrestrial & 0.015 & 30.27 & 97.60 \\
\hline 335 & Op - harvest: manual labour & $\begin{array}{l}\text { Input of litter (solid waste matter, } \\
\text { including micro-sized litter) }\end{array}$ & terrestrial & 0.015 & 30.27 & 97.60 \\
\hline 336 & Op - harvest: mechanical harvest & $\begin{array}{l}\text { Input of litter (solid waste matter, } \\
\text { including micro-sized litter) }\end{array}$ & terrestrial & 0.015 & 30.27 & 97.60 \\
\hline
\end{tabular}




\begin{tabular}{|c|c|c|c|c|c|c|}
\hline 337 & $\begin{array}{l}\text { Op - inoculation: deployment of } \\
\text { the droppers }\end{array}$ & $\begin{array}{l}\text { Input of litter (solid waste matter, } \\
\text { including micro-sized litter) }\end{array}$ & terrestrial & 0.015 & 30.27 & 97.60 \\
\hline 338 & Decom: manual labour & $\begin{array}{l}\text { Input of litter (solid waste matter, } \\
\text { including micro-sized litter) }\end{array}$ & hard sub & 0.015 & 30.27 & 97.62 \\
\hline 339 & $\begin{array}{l}\text { Decom: retrieval of longlines, } \\
\text { buoys and mooring }\end{array}$ & $\begin{array}{l}\text { Input of litter (solid waste matter, } \\
\text { including micro-sized litter) }\end{array}$ & hard sub & 0.015 & 30.27 & 97.62 \\
\hline 340 & $\begin{array}{l}\text { Instal: deployment longlines, } \\
\text { buoys and mooring }\end{array}$ & $\begin{array}{l}\text { Input of litter (solid waste matter, } \\
\text { including micro-sized litter) }\end{array}$ & hard sub & 0.015 & 30.27 & 97.62 \\
\hline 341 & Instal: manual labour & $\begin{array}{l}\text { Input of litter (solid waste matter, } \\
\text { including micro-sized litter) }\end{array}$ & hard sub & 0.015 & 30.27 & 97.62 \\
\hline 342 & $\begin{array}{l}\text { Op - cultivation: early growth } \\
\text { phase }\end{array}$ & $\begin{array}{l}\text { Input of litter (solid waste matter, } \\
\text { including micro-sized litter) }\end{array}$ & hard sub & 0.015 & 30.27 & 97.62 \\
\hline 343 & $\begin{array}{l}\text { Op - cultivation: final growth } \\
\text { phase }\end{array}$ & $\begin{array}{l}\text { Input of litter (solid waste matter, } \\
\text { including micro-sized litter) }\end{array}$ & hard sub & 0.015 & 30.27 & 97.62 \\
\hline 344 & $\begin{array}{l}\text { Op - cultivation: manual } \\
\text { labour/maintenance }\end{array}$ & $\begin{array}{l}\text { Input of litter (solid waste matter, } \\
\text { including micro-sized litter) }\end{array}$ & hard sub & 0.015 & 30.27 & 97.62 \\
\hline 345 & Op - harvest: manual labour & $\begin{array}{l}\text { Input of litter (solid waste matter, } \\
\text { including micro-sized litter) }\end{array}$ & hard sub & 0.015 & 30.27 & 97.62 \\
\hline 346 & Op - harvest: mechanical harvest & $\begin{array}{l}\text { Input of litter (solid waste matter, } \\
\text { including micro-sized litter) }\end{array}$ & hard sub & 0.015 & 30.27 & 97.62 \\
\hline 347 & $\begin{array}{l}\text { Op - inoculation: deployment of } \\
\text { the droppers }\end{array}$ & $\begin{array}{l}\text { Input of litter (solid waste matter, } \\
\text { including micro-sized litter) }\end{array}$ & hard sub & 0.015 & 30.27 & 97.62 \\
\hline 348 & Op - inoculation: manual labour & $\begin{array}{l}\text { Input of litter (solid waste matter, } \\
\text { including micro-sized litter) }\end{array}$ & terrestrial & 0.028 & 30.27 & 97.68 \\
\hline 349 & Op - inoculation: manual labour & $\begin{array}{l}\text { Input of litter (solid waste matter, } \\
\text { including micro-sized litter) }\end{array}$ & hard sub & 0.028 & 30.27 & 97.70 \\
\hline 350 & Decom: manual labour & $\begin{array}{l}\text { Input of litter (solid waste matter, } \\
\text { including micro-sized litter) }\end{array}$ & soft sed & 0.015 & 30.27 & 98.19 \\
\hline 351 & $\begin{array}{l}\text { Decom: retrieval of longlines, } \\
\text { buoys and mooring }\end{array}$ & $\begin{array}{l}\text { Input of litter (solid waste matter, } \\
\text { including micro-sized litter) }\end{array}$ & soft sed & 0.015 & 30.27 & 98.19 \\
\hline 352 & $\begin{array}{l}\text { Instal: deployment longlines, } \\
\text { buoys and mooring }\end{array}$ & $\begin{array}{l}\text { Input of litter (solid waste matter, } \\
\text { including micro-sized litter) }\end{array}$ & soft sed & 0.015 & 30.27 & 98.19 \\
\hline 353 & Instal: manual labour & $\begin{array}{l}\text { Input of litter (solid waste matter, } \\
\text { including micro-sized litter) }\end{array}$ & soft sed & 0.015 & 30.27 & 98.19 \\
\hline 354 & $\begin{array}{l}\text { Op - cultivation: early growth } \\
\text { phase }\end{array}$ & $\begin{array}{l}\text { Input of litter (solid waste matter, } \\
\text { including micro-sized litter) }\end{array}$ & soft sed & 0.015 & 30.27 & 98.19 \\
\hline 355 & $\begin{array}{l}\text { Op - cultivation: final growth } \\
\text { phase }\end{array}$ & $\begin{array}{l}\text { Input of litter (solid waste matter, } \\
\text { including micro-sized litter) }\end{array}$ & soft sed & 0.015 & 30.27 & 98.19 \\
\hline 356 & $\begin{array}{l}\text { Op - cultivation: manual } \\
\text { labour/maintenance }\end{array}$ & $\begin{array}{l}\text { Input of litter (solid waste matter, } \\
\text { including micro-sized litter) }\end{array}$ & soft sed & 0.015 & 30.27 & 98.19 \\
\hline 357 & Op - harvest: manual labour & $\begin{array}{l}\text { Input of litter (solid waste matter, } \\
\text { including micro-sized litter) }\end{array}$ & soft sed & 0.015 & 30.27 & 98.19 \\
\hline 358 & Op - harvest: mechanical harvest & $\begin{array}{l}\text { Input of litter (solid waste matter, } \\
\text { including micro-sized litter) }\end{array}$ & soft sed & 0.015 & 30.27 & 98.19 \\
\hline 359 & $\begin{array}{l}\text { Op - inoculation: deployment of } \\
\text { the droppers }\end{array}$ & $\begin{array}{l}\text { Input of litter (solid waste matter, } \\
\text { including micro-sized litter) }\end{array}$ & soft sed & 0.015 & 30.27 & 98.19 \\
\hline 360 & $\begin{array}{l}\text { Op - cultivation: final growth } \\
\text { phase }\end{array}$ & $\begin{array}{l}\text { Input of litter (solid waste matter, } \\
\text { including micro-sized litter) }\end{array}$ & terrestrial & 0.015 & 30.27 & 98.22 \\
\hline 361 & Op - inoculation: manual labour & $\begin{array}{l}\text { Input of litter (solid waste matter, } \\
\text { including micro-sized litter) }\end{array}$ & soft sed & 0.028 & 30.27 & 98.26 \\
\hline 362 & Decom: manual labour & $\begin{array}{l}\text { Input of litter (solid waste matter, } \\
\text { including micro-sized litter) }\end{array}$ & avial_migratory birds & 0.376 & 54.59 & 900.18 \\
\hline 363 & Decom: manual labour & $\begin{array}{l}\text { Input of litter (solid waste matter, } \\
\text { including micro-sized litter) }\end{array}$ & avial_seabirds & 0.376 & 54.59 & 900.18 \\
\hline 364 & $\begin{array}{l}\text { Decom: retrieval of longlines, } \\
\text { buoys and mooring }\end{array}$ & $\begin{array}{l}\text { Input of litter (solid waste matter, } \\
\text { including micro-sized litter) }\end{array}$ & avial_migratory birds & 0.376 & 54.59 & 900.18 \\
\hline 365 & $\begin{array}{l}\text { Decom: retrieval of longlines, } \\
\text { buoys and mooring }\end{array}$ & $\begin{array}{l}\text { Input of litter (solid waste matter, } \\
\text { including micro-sized litter) }\end{array}$ & avial_seabirds & 0.376 & 54.59 & 900.18 \\
\hline 366 & $\begin{array}{l}\text { Instal: deployment longlines, } \\
\text { buoys and mooring }\end{array}$ & $\begin{array}{l}\text { Input of litter (solid waste matter, } \\
\text { including micro-sized litter) }\end{array}$ & avial migratory birds & 0.376 & 54.59 & 900.18 \\
\hline 367 & $\begin{array}{l}\text { Instal: deployment longlines, } \\
\text { buoys and mooring }\end{array}$ & $\begin{array}{l}\text { Input of litter (solid waste matter, } \\
\text { including micro-sized litter) }\end{array}$ & avial_seabirds & 0.376 & 54.59 & 900.18 \\
\hline 368 & Instal: manual labour & $\begin{array}{l}\text { Input of litter (solid waste matter, } \\
\text { including micro-sized litter) }\end{array}$ & avial_migratory birds & 0.376 & 54.59 & 900.18 \\
\hline 369 & Instal: manual labour & $\begin{array}{l}\text { Input of litter (solid waste matter, } \\
\text { including micro-sized litter) }\end{array}$ & avial_seabirds & 0.376 & 54.59 & 900.18 \\
\hline 370 & $\begin{array}{l}\text { Op - cultivation: early growth } \\
\text { phase }\end{array}$ & $\begin{array}{l}\text { Input of litter (solid waste matter, } \\
\text { including micro-sized litter) }\end{array}$ & avial_migratory birds & 0.376 & 54.59 & 900.18 \\
\hline 371 & $\begin{array}{l}\text { Op - cultivation: early growth } \\
\text { phase }\end{array}$ & $\begin{array}{l}\text { Input of litter (solid waste matter, } \\
\text { including micro-sized litter) }\end{array}$ & avial_seabirds & 0.376 & 54.59 & 900.18 \\
\hline 372 & $\begin{array}{l}\text { Op - cultivation: final growth } \\
\text { phase }\end{array}$ & $\begin{array}{l}\text { Input of litter (solid waste matter, } \\
\text { including micro-sized litter) }\end{array}$ & avial_migratory birds & 0.376 & 54.59 & 900.18 \\
\hline 373 & $\begin{array}{l}\text { Op - cultivation: final growth } \\
\text { phase }\end{array}$ & $\begin{array}{l}\text { Input of litter (solid waste matter, } \\
\text { including micro-sized litter) }\end{array}$ & avial_seabirds & 0.376 & 54.59 & 900.18 \\
\hline
\end{tabular}




\begin{tabular}{|c|c|c|c|c|c|c|}
\hline 374 & $\begin{array}{l}\text { Op - cultivation: manual } \\
\text { labour/maintenance }\end{array}$ & $\begin{array}{l}\text { Input of litter (solid waste matter, } \\
\text { including micro-sized litter) }\end{array}$ & avial_migratory birds & 0.376 & 54.59 & 900.18 \\
\hline 375 & $\begin{array}{l}\text { Op - cultivation: manual } \\
\text { labour/maintenance }\end{array}$ & $\begin{array}{l}\text { Input of litter (solid waste matter, } \\
\text { including micro-sized litter) }\end{array}$ & avial_seabirds & 0.376 & 54.59 & 900.18 \\
\hline 376 & Op - harvest: manual labour & $\begin{array}{l}\text { Input of litter (solid waste matter, } \\
\text { including micro-sized litter) }\end{array}$ & avial_migratory birds & 0.376 & 54.59 & 900.18 \\
\hline 377 & Op - harvest: manual labour & $\begin{array}{l}\text { Input of litter (solid waste matter, } \\
\text { including micro-sized litter) }\end{array}$ & avial seabirds & 0.376 & 54.59 & 900.18 \\
\hline 378 & Op - harvest: mechanical harvest & $\begin{array}{l}\text { Input of litter (solid waste matter, } \\
\text { including micro-sized litter) }\end{array}$ & avial_migratory birds & 0.376 & 54.59 & 900.18 \\
\hline 379 & Op - harvest: mechanical harvest & $\begin{array}{l}\text { Input of litter (solid waste matter, } \\
\text { including micro-sized litter) }\end{array}$ & avial_seabirds & 0.376 & 54.59 & 900.18 \\
\hline 380 & $\begin{array}{l}\text { Op - inoculation: deployment of } \\
\text { the droppers }\end{array}$ & $\begin{array}{l}\text { Input of litter (solid waste matter, } \\
\text { including micro-sized litter) }\end{array}$ & avial_migratory birds & 0.376 & 54.59 & 900.18 \\
\hline 381 & $\begin{array}{l}\text { Op - inoculation: deployment of } \\
\text { the droppers }\end{array}$ & $\begin{array}{l}\text { Input of litter (solid waste matter, } \\
\text { including micro-sized litter) }\end{array}$ & avial_seabirds & 0.376 & 54.59 & 900.18 \\
\hline 382 & Decom: manual labour & $\begin{array}{l}\text { Input of litter (solid waste matter, } \\
\text { including micro-sized litter) }\end{array}$ & fish_adult & 0.376 & 54.59 & 900.18 \\
\hline 383 & $\begin{array}{l}\text { Decom: retrieval of longlines, } \\
\text { buoys and mooring }\end{array}$ & $\begin{array}{l}\text { Input of litter (solid waste matter, } \\
\text { including micro-sized litter) }\end{array}$ & fish_adult & 0.376 & 54.59 & 900.18 \\
\hline 384 & $\begin{array}{l}\text { Instal: deployment longlines, } \\
\text { buoys and mooring }\end{array}$ & $\begin{array}{l}\text { Input of litter (solid waste matter, } \\
\text { including micro-sized litter) }\end{array}$ & fish_adult & 0.376 & 54.59 & 900.18 \\
\hline 385 & Instal: manual labour & $\begin{array}{l}\text { Input of litter (solid waste matter, } \\
\text { including micro-sized litter) }\end{array}$ & fish_adult & 0.376 & 54.59 & 900.18 \\
\hline 386 & $\begin{array}{l}\text { Op - cultivation: early growth } \\
\text { phase }\end{array}$ & $\begin{array}{l}\text { Input of litter (solid waste matter, } \\
\text { including micro-sized litter) }\end{array}$ & fish_adult & 0.376 & 54.59 & 900.18 \\
\hline 387 & $\begin{array}{l}\text { Op - cultivation: final growth } \\
\text { phase }\end{array}$ & $\begin{array}{l}\text { Input of litter (solid waste matter, } \\
\text { including micro-sized litter) }\end{array}$ & fish_adult & 0.376 & 54.59 & 900.18 \\
\hline 388 & $\begin{array}{l}\text { Op - cultivation: manual } \\
\text { labour/maintenance }\end{array}$ & $\begin{array}{l}\text { Input of litter (solid waste matter, } \\
\text { including micro-sized litter) }\end{array}$ & fish_adult & 0.376 & 54.59 & 900.18 \\
\hline 389 & Op - harvest: manual labour & $\begin{array}{l}\text { Input of litter (solid waste matter, } \\
\text { including micro-sized litter) }\end{array}$ & fish_adult & 0.376 & 54.59 & 900.18 \\
\hline 390 & Op - harvest: mechanical harvest & $\begin{array}{l}\text { Input of litter (solid waste matter, } \\
\text { including micro-sized litter) }\end{array}$ & fish_adult & 0.376 & 54.59 & 900.18 \\
\hline 391 & $\begin{array}{l}\text { Op - inoculation: deployment of } \\
\text { the droppers }\end{array}$ & $\begin{array}{l}\text { Input of litter (solid waste matter, } \\
\text { including micro-sized litter) }\end{array}$ & fish_adult & 0.376 & 54.59 & 900.18 \\
\hline 392 & Decom: manual labour & $\begin{array}{l}\text { Input of litter (solid waste matter, } \\
\text { including micro-sized litter) }\end{array}$ & marine $\mathrm{m}$ & 0.376 & 54.59 & 900.18 \\
\hline 393 & $\begin{array}{l}\text { Decom: retrieval of longlines, } \\
\text { buoys and mooring }\end{array}$ & $\begin{array}{l}\text { Input of litter (solid waste matter, } \\
\text { including micro-sized litter) }\end{array}$ & marine mammals & 0.376 & 54.59 & 900.18 \\
\hline 394 & $\begin{array}{l}\text { Instal: deployment longlines, } \\
\text { buoys and mooring }\end{array}$ & $\begin{array}{l}\text { Input of litter (solid waste matter, } \\
\text { including micro-sized litter) }\end{array}$ & marine mammals & 0.376 & 54.59 & 900.18 \\
\hline 395 & Instal: manual labour & $\begin{array}{l}\text { Input of litter (solid waste matter, } \\
\text { including micro-sized litter) }\end{array}$ & nmals & 0.376 & 54.59 & 900.18 \\
\hline 396 & $\begin{array}{l}\text { Op - cultivation: early growth } \\
\text { phase }\end{array}$ & $\begin{array}{l}\text { Input of litter (solid waste matter, } \\
\text { including micro-sized litter) }\end{array}$ & marine mammals & 0.376 & 54.59 & 900.18 \\
\hline 397 & $\begin{array}{l}\text { Op - cultivation: final growth } \\
\text { phase }\end{array}$ & $\begin{array}{l}\text { Input of litter (solid waste matter, } \\
\text { including micro-sized litter) }\end{array}$ & marine mammals & 0.376 & 54.59 & 900.18 \\
\hline 398 & $\begin{array}{l}\text { Op - cultivation: manual } \\
\text { labour/maintenance }\end{array}$ & $\begin{array}{l}\text { Input of litter (solid waste matter, } \\
\text { including micro-sized litter) }\end{array}$ & marine mammals & 0.376 & 54.59 & 900.18 \\
\hline 399 & Op - harvest: manual labour & $\begin{array}{l}\text { Input of litter (solid waste matter, } \\
\text { including micro-sized litter) }\end{array}$ & marine mammals & 0.376 & 54.59 & 900.18 \\
\hline 400 & Op - harvest: mechanical harvest & $\begin{array}{l}\text { Input of litter (solid waste matter, } \\
\text { including micro-sized litter) }\end{array}$ & marine mammals & 0.376 & 54.59 & 900.18 \\
\hline 401 & $\begin{array}{l}\text { Op - inoculation: deployment of } \\
\text { the droppers }\end{array}$ & $\begin{array}{l}\text { Input of litter (solid waste matter, } \\
\text { including micro-sized litter) }\end{array}$ & marine mammals & 0.376 & 54.59 & 900.18 \\
\hline 402 & Op - inoculation: manual labour & $\begin{array}{l}\text { Input of litter (solid waste matter, } \\
\text { including micro-sized litter) }\end{array}$ & avial_migratory birds & 0.376 & 54.59 & 900.87 \\
\hline 403 & Op - inoculation: manual labour & $\begin{array}{l}\text { Input of litter (solid waste matter, } \\
\text { including micro-sized litter) }\end{array}$ & avial_seabirds & 0.376 & 54.59 & 900.87 \\
\hline 404 & Op - inoculation: manual labour & $\begin{array}{l}\text { Input of litter (solid waste matter, } \\
\text { including micro-sized litter) }\end{array}$ & fish_adult & 0.376 & 54.59 & 900.87 \\
\hline 405 & Op - inoculation: manual labour & $\begin{array}{l}\text { Input of litter (solid waste matter, } \\
\text { including micro-sized litter) }\end{array}$ & marine mammals & 0.376 & 54.59 & 900.87 \\
\hline 406 & $\begin{array}{l}\text { Decom: retrieval of longlines, } \\
\text { buoys and mooring }\end{array}$ & $\begin{array}{l}\text { Input of microbial pathogens \& } \\
\text { parasites }\end{array}$ & epiphytes \& epibionts & 0.049 & 3.50 & 8.75 \\
\hline 407 & $\begin{array}{l}\text { Instal: deployment longlines, } \\
\text { buoys and mooring }\end{array}$ & $\begin{array}{l}\text { Input of microbial pathogens \& } \\
\text { parasites }\end{array}$ & epiphytes \& epibionts & 0.049 & 3.50 & 8.75 \\
\hline 408 & $\begin{array}{l}\text { Op - cultivation: early growth } \\
\text { phase }\end{array}$ & $\begin{array}{l}\text { Input of microbial pathogens \& } \\
\text { parasites }\end{array}$ & epiphytes \& epibionts & 0.049 & 3.50 & 8.75 \\
\hline 409 & $\begin{array}{l}\text { Op - cultivation: final growth } \\
\text { phase }\end{array}$ & $\begin{array}{l}\text { Input of microbial pathogens \& } \\
\text { parasites }\end{array}$ & epiphytes \& epibionts & 0.049 & 3.50 & 8.75 \\
\hline 410 & $\begin{array}{l}\text { Op - inoculation: deployment of } \\
\text { the droppers }\end{array}$ & $\begin{array}{l}\text { Input of microbial pathogens \& } \\
\text { parasites }\end{array}$ & epiphytes \& epibionts & 0.049 & 3.50 & 8.75 \\
\hline
\end{tabular}




\begin{tabular}{|c|c|c|c|c|c|c|}
\hline 411 & $\begin{array}{l}\text { Decom: retrieval of longlines, } \\
\text { buoys and mooring }\end{array}$ & $\begin{array}{l}\text { Input of microbial pathogens \& } \\
\text { parasites }\end{array}$ & seaweed \& seagrass & 0.049 & 3.50 & 8.75 \\
\hline 412 & $\begin{array}{l}\text { Instal: deployment longlines, } \\
\text { buoys and mooring }\end{array}$ & $\begin{array}{l}\text { Input of microbial pathogens \& } \\
\text { parasites }\end{array}$ & seaweed \& seagrass & 0.049 & 3.50 & 8.75 \\
\hline 413 & $\begin{array}{l}\text { Op - cultivation: early growth } \\
\text { phase }\end{array}$ & $\begin{array}{l}\text { Input of microbial pathogens \& } \\
\text { parasites }\end{array}$ & seaweed \& seagrass & 0.049 & 3.50 & 8.75 \\
\hline 414 & $\begin{array}{l}\text { Op - cultivation: final growth } \\
\text { phase }\end{array}$ & $\begin{array}{l}\text { Input of microbial pathogens \& } \\
\text { parasites }\end{array}$ & seaweed \& seagrass & 0.049 & 3.50 & 8.75 \\
\hline 415 & $\begin{array}{l}\text { Op - inoculation: deployment of } \\
\text { the droppers }\end{array}$ & $\begin{array}{l}\text { Input of microbial pathogens \& } \\
\text { parasites }\end{array}$ & seaweed \& seagrass & 0.049 & 3.50 & 8.75 \\
\hline 416 & Op - harvest: shipping & $\begin{array}{l}\text { Input of microbial pathogens \& } \\
\text { parasites }\end{array}$ & epiphytes \& epibionts & 0.049 & 3.50 & 8.75 \\
\hline 417 & Op - inoculation: shipping & $\begin{array}{l}\text { Input of microbial pathogens \& } \\
\text { parasites }\end{array}$ & epiphytes \& epibionts & 0.049 & 3.50 & 8.75 \\
\hline 418 & Op - harvest: shipping & $\begin{array}{l}\text { Input of microbial pathogens \& } \\
\text { parasites }\end{array}$ & seaweed \& seagrass & 0.049 & 3.50 & 8.75 \\
\hline 419 & Op - inoculation: shipping & $\begin{array}{l}\text { Input of microbial pathogens \& } \\
\text { parasites }\end{array}$ & seaweed $\&$ seagrass & 0.049 & 3.50 & 8.75 \\
\hline 420 & Op - cultivation: shipping & $\begin{array}{l}\text { Input of microbial pathogens \& } \\
\text { parasites }\end{array}$ & epiphytes \& epibionts & 0.049 & 3.50 & 8.77 \\
\hline 421 & Op - cultivation: shipping & $\begin{array}{l}\text { Input of microbial pathogens \& } \\
\text { parasites }\end{array}$ & seaweed \& seagrass & 0.049 & 3.50 & 8.77 \\
\hline 422 & Decom: shipping & $\begin{array}{l}\text { Input of microbial pathogens \& } \\
\text { parasites }\end{array}$ & epiphytes \& epibionts & 0.050 & 3.50 & 9.00 \\
\hline 423 & Instal: shipping & $\begin{array}{l}\text { Input of microbial pathogens \& } \\
\text { parasites }\end{array}$ & epiphytes \& epibionts & 0.050 & 3.50 & 9.00 \\
\hline 424 & Decom: shipping & $\begin{array}{l}\text { Input of microbial pathogens \& } \\
\text { parasites }\end{array}$ & seaweed $\&$ seagrass & 0.050 & 3.50 & 9.00 \\
\hline 425 & Instal: shipping & $\begin{array}{l}\text { Input of microbial pathogens \& } \\
\text { parasites }\end{array}$ & seaweed \& seagrass & 0.050 & 3.50 & 9.00 \\
\hline 426 & $\begin{array}{l}\text { Decom: retrieval of longlines, } \\
\text { buoys and mooring }\end{array}$ & Input of organic matter & seaweed \& seagrass & 0.002 & 3.50 & 8.33 \\
\hline 427 & $\begin{array}{l}\text { Op - cultivation: final growth } \\
\text { phase }\end{array}$ & Input of organic matter & seaweed \& seagrass & 0.004 & 3.50 & 8.41 \\
\hline 428 & Op - harvest: mechanical harvest & Input of organic matter & seaweed \& seagrass & 0.004 & 3.50 & 8.41 \\
\hline 429 & $\begin{array}{l}\text { Op - inoculation: deployment of } \\
\text { the droppers }\end{array}$ & Input of organic matter & seaweed \& seagrass & 0.004 & 3.50 & 8.41 \\
\hline 430 & $\begin{array}{l}\text { Decom: retrieval of longlines, } \\
\text { buoys and mooring }\end{array}$ & Input of organic matter & soft sed & 0.018 & 3.50 & 8.94 \\
\hline 431 & $\begin{array}{l}\text { Decom: retrieval of longlines, } \\
\text { buoys and mooring }\end{array}$ & Input of organic matter & benthos_on & 0.018 & 3.50 & 8.97 \\
\hline 432 & $\begin{array}{l}\text { Op - cultivation: early growth } \\
\text { phase }\end{array}$ & Input of organic matter & seaweed \& seagrass & 0.014 & 3.50 & 9.01 \\
\hline 433 & $\begin{array}{l}\text { Op - cultivation: final growth } \\
\text { phase }\end{array}$ & Input of organic matter & soft sed & 0.027 & 3.50 & 9.01 \\
\hline 434 & Op - harvest: mechanical harvest & Input of organic matter & soft sed & 0.027 & 3.50 & 9.01 \\
\hline 435 & $\begin{array}{l}\text { Op - inoculation: deployment of } \\
\text { the droppers }\end{array}$ & Input of organic matter & soft sed & 0.027 & 3.50 & 9.01 \\
\hline 436 & $\begin{array}{l}\text { Op - cultivation: final growth } \\
\text { phase }\end{array}$ & Input of organic matter & benthos_on & 0.027 & 3.50 & 9.04 \\
\hline 437 & Op - harvest: mechanical harvest & Input of organic matter & benthos_on & 0.027 & 3.50 & 9.04 \\
\hline 438 & $\begin{array}{l}\text { Op - inoculation: deployment of } \\
\text { the droppers }\end{array}$ & Input of organic matter & benthos_on & 0.027 & 3.50 & 9.04 \\
\hline 439 & $\begin{array}{l}\text { Op - cultivation: early growth } \\
\text { phase }\end{array}$ & Input of organic matter & soft sed & 0.045 & 3.50 & 9.61 \\
\hline 440 & $\begin{array}{l}\text { Op - cultivation: early growth } \\
\text { phase }\end{array}$ & Input of organic matter & benthos_on & 0.046 & 3.50 & 9.65 \\
\hline 441 & $\begin{array}{l}\text { Op - cultivation: early growth } \\
\text { phase }\end{array}$ & $\begin{array}{l}\text { Input or spread of non-indigenous } \\
\text { species }\end{array}$ & plankton & 0.000 & 27.79 & 16.38 \\
\hline 442 & $\begin{array}{l}\text { Op - cultivation: final growth } \\
\text { phase }\end{array}$ & $\begin{array}{l}\text { Input or spread of non-indigenous } \\
\text { species }\end{array}$ & plankton & 0.000 & 27.79 & 16.38 \\
\hline 443 & $\begin{array}{l}\text { Op - inoculation: deployment of } \\
\text { the droppers }\end{array}$ & $\begin{array}{l}\text { Input or spread of non-indigenous } \\
\text { species }\end{array}$ & plankton & 0.000 & 27.79 & 16.38 \\
\hline 444 & Op - harvest: shipping & $\begin{array}{l}\text { Input or spread of non-indigenous } \\
\text { species }\end{array}$ & plankton & 0.000 & 27.79 & 16.42 \\
\hline 445 & Op - inoculation: shipping & $\begin{array}{l}\text { Input or spread of non-indigenous } \\
\text { species }\end{array}$ & plankton & 0.000 & 27.79 & 16.42 \\
\hline 446 & Op - cultivation: shipping & $\begin{array}{l}\text { Input or spread of non-indigenous } \\
\text { species }\end{array}$ & plankton & 0.000 & 27.79 & 17.11 \\
\hline 447 & Decom: shipping & $\begin{array}{l}\text { Input or spread of non-indigenous } \\
\text { species }\end{array}$ & plankton & 0.000 & 27.75 & 23.21 \\
\hline 448 & Instal: shipping & $\begin{array}{l}\text { Input or spread of non-indigenous } \\
\text { species }\end{array}$ & plankton & 0.000 & 27.75 & 23.21 \\
\hline
\end{tabular}




\begin{tabular}{|c|c|c|c|c|c|c|}
\hline 449 & $\begin{array}{l}\text { Op - cultivation: early growth } \\
\text { phase }\end{array}$ & $\begin{array}{l}\text { Input or spread of non-indigenous } \\
\text { species }\end{array}$ & epiphytes \& epibionts & 0.127 & 30.27 & 97.78 \\
\hline 450 & $\begin{array}{l}\text { Op - cultivation: final growth } \\
\text { phase }\end{array}$ & $\begin{array}{l}\text { Input or spread of non-indigenous } \\
\text { species }\end{array}$ & epiphytes \& epibionts & 0.127 & 30.27 & 97.78 \\
\hline 451 & $\begin{array}{l}\text { Op - inoculation: deployment of } \\
\text { the droppers }\end{array}$ & $\begin{array}{l}\text { Input or spread of non-indigenous } \\
\text { species }\end{array}$ & epiphytes \& epibionts & 0.127 & 30.27 & 97.78 \\
\hline 452 & $\begin{array}{l}\text { Op - cultivation: early growth } \\
\text { phase }\end{array}$ & $\begin{array}{l}\text { Input or spread of non-indigenous } \\
\text { species }\end{array}$ & seaweed \& seagrass & 0.127 & 30.27 & 97.78 \\
\hline 453 & $\begin{array}{l}\text { Op - cultivation: final growth } \\
\text { phase }\end{array}$ & $\begin{array}{l}\text { Input or spread of non-indigenous } \\
\text { species }\end{array}$ & seaweed \& seagrass & 0.127 & 30.27 & 97.78 \\
\hline 454 & $\begin{array}{l}\text { Op - inoculation: deployment of } \\
\text { the droppers }\end{array}$ & $\begin{array}{l}\text { Input or spread of non-indigenous } \\
\text { species }\end{array}$ & seaweed $\&$ seagrass & 0.127 & 30.27 & 97.78 \\
\hline 455 & Op - harvest: shipping & $\begin{array}{l}\text { Input or spread of non-indigenous } \\
\text { species }\end{array}$ & epiphytes \& epibionts & 0.127 & 30.27 & 97.78 \\
\hline 456 & Op - inoculation: shipping & $\begin{array}{l}\text { Input or spread of non-indigenous } \\
\text { species }\end{array}$ & epiphytes \& epibionts & 0.127 & 30.27 & 97.78 \\
\hline 457 & Op - harvest: shipping & $\begin{array}{l}\text { Input or spread of non-indigenous } \\
\text { species }\end{array}$ & seaweed $\&$ seagrass & 0.127 & 30.27 & 97.78 \\
\hline 458 & Op - inoculation: shipping & $\begin{array}{l}\text { Input or spread of non-indigenous } \\
\text { species }\end{array}$ & seaweed $\&$ seagrass & 0.127 & 30.27 & 97.78 \\
\hline 459 & Op - cultivation: shipping & $\begin{array}{l}\text { Input or spread of non-indigenous } \\
\text { species }\end{array}$ & epiphytes \& epibionts & 0.127 & 30.27 & 97.81 \\
\hline 460 & Op - cultivation: shipping & $\begin{array}{l}\text { Input or spread of non-indigenous } \\
\text { species }\end{array}$ & seaweed \& seagrass & 0.127 & 30.27 & 97.81 \\
\hline 461 & $\begin{array}{l}\text { Op - cultivation: early growth } \\
\text { phase }\end{array}$ & $\begin{array}{l}\text { Input or spread of non-indigenous } \\
\text { species }\end{array}$ & benthos_off & 0.127 & 30.27 & 97.86 \\
\hline 462 & $\begin{array}{l}\text { Op - cultivation: final growth } \\
\text { phase }\end{array}$ & $\begin{array}{l}\text { Input or spread of non-indigenous } \\
\text { species }\end{array}$ & benthos_off & 0.127 & 30.27 & 97.86 \\
\hline 463 & $\begin{array}{l}\text { Op - inoculation: deployment of } \\
\text { the droppers }\end{array}$ & $\begin{array}{l}\text { Input or spread of non-indigenous } \\
\text { species }\end{array}$ & benthos_off & 0.127 & 30.27 & 97.86 \\
\hline 464 & Op - harvest: shipping & $\begin{array}{l}\text { Input or spread of non-indigenous } \\
\text { species }\end{array}$ & benthos_off & 0.127 & 30.27 & 97.88 \\
\hline 465 & Op - inoculation: shipping & $\begin{array}{l}\text { Input or spread of non-indigenous } \\
\text { species }\end{array}$ & benthos_off & 0.127 & 30.27 & 97.88 \\
\hline 466 & Decom: shipping & $\begin{array}{l}\text { Input or spread of non-indigenous } \\
\text { species }\end{array}$ & epiphytes \& epibionts & 0.127 & 30.27 & 98.02 \\
\hline 467 & Instal: shipping & $\begin{array}{l}\text { Input or spread of non-indigenous } \\
\text { species }\end{array}$ & epiphytes \& epibionts & 0.127 & 30.27 & 98.02 \\
\hline 468 & Decom: shipping & $\begin{array}{l}\text { Input or spread of non-indigenous } \\
\text { species }\end{array}$ & seaweed \& seagrass & 0.127 & 30.27 & 98.02 \\
\hline 469 & Instal: shipping & $\begin{array}{l}\text { Input or spread of non-indigenous } \\
\text { species }\end{array}$ & seaweed $\&$ seagrass & 0.127 & 30.27 & 98.02 \\
\hline 470 & Op - cultivation: shipping & $\begin{array}{l}\text { Input or spread of non-indigenous } \\
\text { species }\end{array}$ & benthos_off & 0.127 & 30.27 & 98.39 \\
\hline 471 & $\begin{array}{l}\text { Op - cultivation: early growth } \\
\text { phase }\end{array}$ & $\begin{array}{l}\text { Input or spread of non-indigenous } \\
\text { species }\end{array}$ & benthos_on & 0.127 & 30.27 & 98.40 \\
\hline 472 & $\begin{array}{l}\text { Op - cultivation: final growth } \\
\text { phase }\end{array}$ & $\begin{array}{l}\text { Input or spread of non-indigenous } \\
\text { species }\end{array}$ & benthos_on & 0.127 & 30.27 & 98.40 \\
\hline 473 & $\begin{array}{l}\text { Op - inoculation: deployment of } \\
\text { the droppers }\end{array}$ & $\begin{array}{l}\text { Input or spread of non-indigenous } \\
\text { species }\end{array}$ & benthos_on & 0.127 & 30.27 & 98.40 \\
\hline 474 & Op - harvest: shipping & $\begin{array}{l}\text { Input or spread of non-indigenous } \\
\text { species }\end{array}$ & benthos_on & 0.127 & 30.27 & 98.61 \\
\hline 475 & Op - inoculation: shipping & $\begin{array}{l}\text { Input or spread of non-indigenous } \\
\text { species }\end{array}$ & benthos on & 0.127 & 30.27 & 98.61 \\
\hline 476 & Op - cultivation: shipping & $\begin{array}{l}\text { Input or spread of non-indigenous } \\
\text { species }\end{array}$ & benthos_on & 0.130 & 30.27 & 102.77 \\
\hline 477 & Decom: shipping & $\begin{array}{l}\text { Input or spread of non-indigenous } \\
\text { species }\end{array}$ & benthos_off & 0.130 & 30.27 & 102.91 \\
\hline 478 & Instal: shipping & $\begin{array}{l}\text { Input or spread of non-indigenous } \\
\text { species }\end{array}$ & benthos_off & 0.130 & 30.27 & 102.91 \\
\hline 479 & Decom: shipping & $\begin{array}{l}\text { Input or spread of non-indigenous } \\
\text { species }\end{array}$ & benthos on & 0.150 & 30.23 & 139.41 \\
\hline 480 & Instal: shipping & $\begin{array}{l}\text { Input or spread of non-indigenous } \\
\text { species }\end{array}$ & benthos_on & 0.150 & 30.23 & 139.41 \\
\hline 481 & $\begin{array}{l}\text { Decom: retrieval of longlines, } \\
\text { buoys and mooring }\end{array}$ & $\begin{array}{l}\text { Introduction of non-synthetic } \\
\text { substances and compounds }\end{array}$ & plankton & 0.000 & 0.99 & 9.63 \\
\hline 482 & $\begin{array}{l}\text { Instal: deployment longlines, } \\
\text { buoys and mooring }\end{array}$ & $\begin{array}{l}\text { Introduction of non-synthetic } \\
\text { substances and compounds }\end{array}$ & plankton & 0.000 & 0.99 & 9.63 \\
\hline 483 & $\begin{array}{l}\text { Op - inoculation: deployment of } \\
\text { the droppers }\end{array}$ & $\begin{array}{l}\text { Introduction of non-synthetic } \\
\text { substances and compounds }\end{array}$ & plankton & 0.000 & 0.99 & 9.63 \\
\hline 484 & Op - harvest: shipping & $\begin{array}{l}\text { Introduction of non-synthetic } \\
\text { substances and compounds }\end{array}$ & plankton & 0.000 & 0.99 & 9.66 \\
\hline 485 & Op - inoculation: shipping & $\begin{array}{l}\text { Introduction of non-synthetic } \\
\text { substances and compounds }\end{array}$ & plankton & 0.000 & 0.99 & 9.66 \\
\hline
\end{tabular}




\begin{tabular}{|c|c|c|c|c|c|c|}
\hline 486 & Op - cultivation: shipping & $\begin{array}{l}\text { Introduction of non-synthetic } \\
\text { substances and compounds }\end{array}$ & plankton & 0.000 & 0.99 & 10.35 \\
\hline 487 & $\begin{array}{l}\text { Decom: retrieval of longlines, } \\
\text { buoys and mooring }\end{array}$ & $\begin{array}{l}\text { Introduction of non-synthetic } \\
\text { substances and compounds }\end{array}$ & water column & 0.047 & 3.47 & 13.31 \\
\hline 488 & $\begin{array}{l}\text { Instal: deployment longlines, } \\
\text { buoys and mooring }\end{array}$ & $\begin{array}{l}\text { Introduction of non-synthetic } \\
\text { substances and compounds }\end{array}$ & water column & 0.047 & 3.47 & 13.31 \\
\hline 489 & $\begin{array}{l}\text { Op - inoculation: deployment of } \\
\text { the droppers }\end{array}$ & $\begin{array}{l}\text { Introduction of non-synthetic } \\
\text { substances and compounds }\end{array}$ & water column & 0.047 & 3.47 & 13.31 \\
\hline 490 & Op - harvest: shipping & $\begin{array}{l}\text { Introduction of non-synthetic } \\
\text { substances and compounds }\end{array}$ & water column & 0.047 & 3.47 & 13.36 \\
\hline 491 & Op - inoculation: shipping & $\begin{array}{l}\text { Introduction of non-synthetic } \\
\text { substances and compounds }\end{array}$ & water column & 0.047 & 3.47 & 13.36 \\
\hline 492 & Op - cultivation: shipping & $\begin{array}{l}\text { Introduction of non-synthetic } \\
\text { substances and compounds }\end{array}$ & water column & 0.048 & 3.47 & 14.26 \\
\hline 493 & Decom: shipping & $\begin{array}{l}\text { Introduction of non-synthetic } \\
\text { substances and compounds }\end{array}$ & plankton & 0.000 & 0.99 & 16.45 \\
\hline 494 & Instal: shipping & $\begin{array}{l}\text { Introduction of non-synthetic } \\
\text { substances and compounds }\end{array}$ & plankton & 0.000 & 0.99 & 16.45 \\
\hline 495 & Decom: shipping & $\begin{array}{l}\text { Introduction of non-synthetic } \\
\text { substances and compounds }\end{array}$ & water column & 0.055 & 3.47 & 22.18 \\
\hline 496 & Instal: shipping & $\begin{array}{l}\text { Introduction of non-synthetic } \\
\text { substances and compounds }\end{array}$ & water column & 0.055 & 3.47 & 22.18 \\
\hline 497 & $\begin{array}{l}\text { Decom: retrieval of longlines, } \\
\text { buoys and mooring }\end{array}$ & $\begin{array}{l}\text { Introduction of non-synthetic } \\
\text { substances and compounds }\end{array}$ & epiphytes \& epibionts & 0.364 & 5.95 & 63.87 \\
\hline 498 & $\begin{array}{l}\text { Instal: deployment longlines, } \\
\text { buoys and mooring }\end{array}$ & $\begin{array}{l}\text { Introduction of non-synthetic } \\
\text { substances and compounds }\end{array}$ & epiphytes \& epibionts & 0.364 & 5.95 & 63.87 \\
\hline 499 & $\begin{array}{l}\text { Op - inoculation: deployment of } \\
\text { the droppers }\end{array}$ & $\begin{array}{l}\text { Introduction of non-synthetic } \\
\text { substances and compounds }\end{array}$ & epiphytes \& epibionts & 0.364 & 5.95 & 63.87 \\
\hline 500 & $\begin{array}{l}\text { Decom: retrieval of longlines, } \\
\text { buoys and mooring }\end{array}$ & $\begin{array}{l}\text { Introduction of non-synthetic } \\
\text { substances and compounds }\end{array}$ & seaweed \& seagrass & 0.364 & 5.95 & 63.87 \\
\hline 501 & $\begin{array}{l}\text { Instal: deployment longlines, } \\
\text { buoys and mooring }\end{array}$ & $\begin{array}{l}\text { Introduction of non-synthetic } \\
\text { substances and compounds }\end{array}$ & seaweed $\&$ seagrass & 0.364 & 5.95 & 63.87 \\
\hline 502 & $\begin{array}{l}\text { Op - inoculation: deployment of } \\
\text { the droppers }\end{array}$ & $\begin{array}{l}\text { Introduction of non-synthetic } \\
\text { substances and compounds }\end{array}$ & seaweed \& seagrass & 0.364 & 5.95 & 63.87 \\
\hline 503 & Op - inoculation: shipping & $\begin{array}{l}\text { Introduction of non-synthetic } \\
\text { substances and compounds }\end{array}$ & epiphytes \& epibionts & 0.364 & 5.95 & 63.87 \\
\hline 504 & Op - inoculation: shipping & $\begin{array}{l}\text { Introduction of non-synthetic } \\
\text { substances and compounds }\end{array}$ & seaweed $\&$ seagrass & 0.364 & 5.95 & 63.87 \\
\hline 505 & $\begin{array}{l}\text { Decom: retrieval of longlines, } \\
\text { buoys and mooring }\end{array}$ & $\begin{array}{l}\text { Introduction of non-synthetic } \\
\text { substances and compounds }\end{array}$ & terrestrial & 0.364 & 5.95 & 63.88 \\
\hline 506 & Decom: shipping & $\begin{array}{l}\text { Introduction of non-synthetic } \\
\text { substances and compounds }\end{array}$ & terrestrial & 0.364 & 5.95 & 63.88 \\
\hline 507 & $\begin{array}{l}\text { Instal: deployment longlines, } \\
\text { buoys and mooring }\end{array}$ & $\begin{array}{l}\text { Introduction of non-synthetic } \\
\text { substances and compounds }\end{array}$ & terrestrial & 0.364 & 5.95 & 63.88 \\
\hline 508 & Instal: shipping & $\begin{array}{l}\text { Introduction of non-synthetic } \\
\text { substances and compounds }\end{array}$ & terrestrial & 0.364 & 5.95 & 63.88 \\
\hline 509 & Op - cultivation: shipping & $\begin{array}{l}\text { Introduction of non-synthetic } \\
\text { substances and compounds }\end{array}$ & terrestrial & 0.364 & 5.95 & 63.88 \\
\hline 510 & Op - harvest: shipping & $\begin{array}{l}\text { Introduction of non-synthetic } \\
\text { substances and compounds }\end{array}$ & terrestrial & 0.364 & 5.95 & 63.88 \\
\hline 511 & $\begin{array}{l}\text { Op - inoculation: deployment of } \\
\text { the droppers }\end{array}$ & $\begin{array}{l}\text { Introduction of non-synthetic } \\
\text { substances and compounds }\end{array}$ & terrestrial & 0.364 & 5.95 & 63.88 \\
\hline 512 & Op - inoculation: shipping & $\begin{array}{l}\text { Introduction of non-synthetic } \\
\text { substances and compounds }\end{array}$ & terrestrial & 0.364 & 5.95 & 63.88 \\
\hline 513 & Op - cultivation: shipping & $\begin{array}{l}\text { Introduction of non-synthetic } \\
\text { substances and compounds }\end{array}$ & epiphytes \& epibionts & 0.364 & 5.95 & 63.90 \\
\hline 514 & Op - cultivation: shipping & $\begin{array}{l}\text { Introduction of non-synthetic } \\
\text { substances and compounds }\end{array}$ & seaweed \& seagrass & 0.364 & 5.95 & 63.90 \\
\hline 515 & Decom: shipping & $\begin{array}{l}\text { Introduction of non-synthetic } \\
\text { substances and compounds }\end{array}$ & epiphytes \& epibionts & 0.365 & 5.95 & 64.12 \\
\hline 516 & Instal: shipping & $\begin{array}{l}\text { Introduction of non-synthetic } \\
\text { substances and compounds }\end{array}$ & epiphytes \& epibionts & 0.365 & 5.95 & 64.12 \\
\hline 517 & Decom: shipping & $\begin{array}{l}\text { Introduction of non-synthetic } \\
\text { substances and compounds }\end{array}$ & seaweed \& seagrass & 0.365 & 5.95 & 64.12 \\
\hline 518 & Instal: shipping & $\begin{array}{l}\text { Introduction of non-synthetic } \\
\text { substances and compounds }\end{array}$ & seaweed \& seagrass & 0.365 & 5.95 & 64.12 \\
\hline 519 & Op - harvest: shipping & $\begin{array}{l}\text { Introduction of non-synthetic } \\
\text { substances and compounds }\end{array}$ & epiphytes \& epibionts & 0.364 & 30.27 & 102.46 \\
\hline 520 & Op - harvest: shipping & $\begin{array}{l}\text { Introduction of non-synthetic } \\
\text { substances and compounds }\end{array}$ & seaweed \& seagrass & 0.364 & 30.27 & 102.46 \\
\hline 521 & $\begin{array}{l}\text { Decom: retrieval of longlines, } \\
\text { buoys and mooring }\end{array}$ & $\begin{array}{l}\text { Introduction of non-synthetic } \\
\text { substances and compounds }\end{array}$ & hard sub & 0.364 & 30.27 & 102.49 \\
\hline 522 & $\begin{array}{l}\text { Instal: deployment longlines, } \\
\text { buoys and mooring }\end{array}$ & $\begin{array}{l}\text { Introduction of non-synthetic } \\
\text { substances and compounds }\end{array}$ & hard sub & 0.364 & 30.27 & 102.49 \\
\hline
\end{tabular}




\begin{tabular}{|c|c|c|c|c|c|c|}
\hline 523 & $\begin{array}{l}\text { Op - inoculation: deployment of } \\
\text { the droppers }\end{array}$ & $\begin{array}{l}\text { Introduction of non-synthetic } \\
\text { substances and compounds }\end{array}$ & hard sub & 0.364 & 30.27 & 102.49 \\
\hline 524 & Op - harvest: shipping & $\begin{array}{l}\text { Introduction of non-synthetic } \\
\text { substances and compounds }\end{array}$ & hard sub & 0.364 & 30.27 & 102.50 \\
\hline 525 & Op - inoculation: shipping & $\begin{array}{l}\text { Introduction of non-synthetic } \\
\text { substances and compounds }\end{array}$ & hard sub & 0.364 & 30.27 & 102.50 \\
\hline 526 & $\begin{array}{l}\text { Decom: retrieval of longlines, } \\
\text { buoys and mooring }\end{array}$ & $\begin{array}{l}\text { Introduction of non-synthetic } \\
\text { substances and compounds }\end{array}$ & benthos_off & 0.364 & 30.27 & 102.53 \\
\hline 527 & $\begin{array}{l}\text { Instal: deployment longlines, } \\
\text { buoys and mooring }\end{array}$ & $\begin{array}{l}\text { Introduction of non-synthetic } \\
\text { substances and compounds }\end{array}$ & benthos_off & 0.364 & 30.27 & 102.53 \\
\hline 528 & $\begin{array}{l}\text { Op - inoculation: deployment of } \\
\text { the droppers }\end{array}$ & $\begin{array}{l}\text { Introduction of non-synthetic } \\
\text { substances and compounds }\end{array}$ & benthos_off & 0.364 & 30.27 & 102.53 \\
\hline 529 & Op - harvest: shipping & $\begin{array}{l}\text { Introduction of non-synthetic } \\
\text { substances and compounds }\end{array}$ & benthos_off & 0.364 & 30.27 & 102.56 \\
\hline 530 & Op - inoculation: shipping & $\begin{array}{l}\text { Introduction of non-synthetic } \\
\text { substances and compounds }\end{array}$ & benthos_off & 0.364 & 30.27 & 102.56 \\
\hline 531 & Op - cultivation: shipping & $\begin{array}{l}\text { Introduction of non-synthetic } \\
\text { substances and compounds }\end{array}$ & hard sub & 0.365 & 30.27 & 102.72 \\
\hline 532 & $\begin{array}{l}\text { Decom: retrieval of longlines, } \\
\text { buoys and mooring }\end{array}$ & $\begin{array}{l}\text { Introduction of non-synthetic } \\
\text { substances and compounds }\end{array}$ & soft sed & 0.365 & 30.27 & 103.08 \\
\hline 533 & $\begin{array}{l}\text { Instal: deployment longlines, } \\
\text { buoys and mooring }\end{array}$ & $\begin{array}{l}\text { Introduction of non-synthetic } \\
\text { substances and compounds }\end{array}$ & soft sed & 0.365 & 30.27 & 103.08 \\
\hline 534 & $\begin{array}{l}\text { Op - inoculation: deployment of } \\
\text { the droppers }\end{array}$ & $\begin{array}{l}\text { Introduction of non-synthetic } \\
\text { substances and compounds }\end{array}$ & soft sed & 0.365 & 30.27 & 103.08 \\
\hline 535 & Op - cultivation: shipping & $\begin{array}{l}\text { Introduction of non-synthetic } \\
\text { substances and compounds }\end{array}$ & benthos_off & 0.365 & 30.27 & 103.10 \\
\hline 536 & $\begin{array}{l}\text { Decom: retrieval of longlines, } \\
\text { buoys and mooring }\end{array}$ & $\begin{array}{l}\text { Introduction of non-synthetic } \\
\text { substances and compounds }\end{array}$ & benthos_on & 0.365 & 30.27 & 103.11 \\
\hline 537 & $\begin{array}{l}\text { Instal: deployment longlines, } \\
\text { buoys and mooring }\end{array}$ & $\begin{array}{l}\text { Introduction of non-synthetic } \\
\text { substances and compounds }\end{array}$ & benthos_on & 0.365 & 30.27 & 103.11 \\
\hline 538 & $\begin{array}{l}\text { Op - inoculation: deployment of } \\
\text { the droppers }\end{array}$ & $\begin{array}{l}\text { Introduction of non-synthetic } \\
\text { substances and compounds }\end{array}$ & benthos_on & 0.365 & 30.27 & 103.11 \\
\hline 539 & Op - harvest: shipping & $\begin{array}{l}\text { Introduction of non-synthetic } \\
\text { substances and compounds }\end{array}$ & soft sed & 0.365 & 30.27 & 103.28 \\
\hline 540 & Op - inoculation: shipping & $\begin{array}{l}\text { Introduction of non-synthetic } \\
\text { substances and compounds }\end{array}$ & soft sed & 0.365 & 30.27 & 103.28 \\
\hline 541 & Op - harvest: shipping & $\begin{array}{l}\text { Introduction of non-synthetic } \\
\text { substances and compounds }\end{array}$ & benthos_on & 0.366 & 30.27 & 103.33 \\
\hline 542 & Op - inoculation: shipping & $\begin{array}{l}\text { Introduction of non-synthetic } \\
\text { substances and compounds }\end{array}$ & benthos_on & 0.366 & 30.27 & 103.33 \\
\hline 543 & Decom: shipping & $\begin{array}{l}\text { Introduction of non-synthetic } \\
\text { substances and compounds }\end{array}$ & hard sub & 0.368 & 30.27 & 104.64 \\
\hline 544 & Instal: shipping & $\begin{array}{l}\text { Introduction of non-synthetic } \\
\text { substances and compounds }\end{array}$ & hard sub & 0.368 & 30.27 & 104.64 \\
\hline 545 & Op - cultivation: shipping & $\begin{array}{l}\text { Introduction of non-synthetic } \\
\text { substances and compounds }\end{array}$ & soft sed & 0.372 & 30.27 & 107.43 \\
\hline 546 & Op - cultivation: shipping & $\begin{array}{l}\text { Introduction of non-synthetic } \\
\text { substances and compounds }\end{array}$ & benthos_on & 0.372 & 30.27 & 107.69 \\
\hline 547 & Decom: shipping & $\begin{array}{l}\text { Introduction of non-synthetic } \\
\text { substances and compounds }\end{array}$ & benthos_off & 0.372 & 30.27 & 107.83 \\
\hline 548 & Instal: shipping & $\begin{array}{l}\text { Introduction of non-synthetic } \\
\text { substances and compounds }\end{array}$ & benthos_off & 0.372 & 30.27 & 107.83 \\
\hline 549 & Decom: shipping & $\begin{array}{l}\text { Introduction of non-synthetic } \\
\text { substances and compounds }\end{array}$ & soft sed & 0.428 & 30.23 & 143.90 \\
\hline 550 & Instal: shipping & $\begin{array}{l}\text { Introduction of non-synthetic } \\
\text { substances and compounds }\end{array}$ & soft sed & 0.428 & 30.23 & 143.90 \\
\hline 551 & Decom: shipping & $\begin{array}{l}\text { Introduction of non-synthetic } \\
\text { substances and compounds }\end{array}$ & benthos_on & 0.431 & 30.23 & 146.08 \\
\hline 552 & Instal: shipping & $\begin{array}{l}\text { Introduction of non-synthetic } \\
\text { substances and compounds }\end{array}$ & benthos_on & 0.431 & 30.23 & 146.08 \\
\hline 553 & $\begin{array}{l}\text { Decom: retrieval of longlines, } \\
\text { buoys and mooring }\end{array}$ & $\begin{array}{l}\text { Introduction of non-synthetic } \\
\text { substances and compounds }\end{array}$ & avial_migratory birds & 0.389 & 54.59 & 905.08 \\
\hline 554 & $\begin{array}{l}\text { Decom: retrieval of longlines, } \\
\text { buoys and mooring }\end{array}$ & $\begin{array}{l}\text { Introduction of non-synthetic } \\
\text { substances and compounds }\end{array}$ & avial_seabirds & 0.389 & 54.59 & 905.08 \\
\hline 555 & $\begin{array}{l}\text { Instal: deployment longlines, } \\
\text { buoys and mooring }\end{array}$ & $\begin{array}{l}\text { Introduction of non-synthetic } \\
\text { substances and compounds }\end{array}$ & avial_migratory birds & 0.389 & 54.59 & 905.08 \\
\hline 556 & $\begin{array}{l}\text { Instal: deployment longlines, } \\
\text { buoys and mooring }\end{array}$ & $\begin{array}{l}\text { Introduction of non-synthetic } \\
\text { substances and compounds }\end{array}$ & avial_seabirds & 0.389 & 54.59 & 905.08 \\
\hline 557 & $\begin{array}{l}\text { Op - inoculation: deployment of } \\
\text { the droppers }\end{array}$ & $\begin{array}{l}\text { Introduction of non-synthetic } \\
\text { substances and compounds }\end{array}$ & avial_migratory birds & 0.389 & 54.59 & 905.08 \\
\hline 558 & $\begin{array}{l}\text { Op - inoculation: deployment of } \\
\text { the droppers }\end{array}$ & $\begin{array}{l}\text { Introduction of non-synthetic } \\
\text { substances and compounds }\end{array}$ & avial_seabirds & 0.389 & 54.59 & 905.08 \\
\hline 559 & $\begin{array}{l}\text { Decom: retrieval of longlines, } \\
\text { buoys and mooring }\end{array}$ & $\begin{array}{l}\text { Introduction of non-synthetic } \\
\text { substances and compounds }\end{array}$ & fish_adult & 0.389 & 54.59 & 905.08 \\
\hline
\end{tabular}




\begin{tabular}{|c|c|c|c|c|c|c|}
\hline 560 & $\begin{array}{l}\text { Decom: retrieval of longlines, } \\
\text { buoys and mooring }\end{array}$ & $\begin{array}{l}\text { Introduction of non-synthetic } \\
\text { substances and compounds }\end{array}$ & fish_juv & 0.389 & 54.59 & 905.08 \\
\hline 561 & $\begin{array}{l}\text { Instal: deployment longlines, } \\
\text { buoys and mooring }\end{array}$ & $\begin{array}{l}\text { Introduction of non-synthetic } \\
\text { substances and compounds }\end{array}$ & fish_adult & 0.389 & 54.59 & 905.08 \\
\hline 562 & $\begin{array}{l}\text { Instal: deployment longlines, } \\
\text { buoys and mooring }\end{array}$ & $\begin{array}{l}\text { Introduction of non-synthetic } \\
\text { substances and compounds }\end{array}$ & fish_juv & 0.389 & 54.59 & 905.08 \\
\hline 563 & $\begin{array}{l}\text { Op - inoculation: deployment of } \\
\text { the droppers }\end{array}$ & $\begin{array}{l}\text { Introduction of non-synthetic } \\
\text { substances and compounds }\end{array}$ & fish adult & 0.389 & 54.59 & 905.08 \\
\hline 564 & $\begin{array}{l}\text { Op - inoculation: deployment of } \\
\text { the droppers }\end{array}$ & $\begin{array}{l}\text { Introduction of non-synthetic } \\
\text { substances and compounds }\end{array}$ & fish_juv & 0.389 & 54.59 & 905.08 \\
\hline 565 & $\begin{array}{l}\text { Decom: retrieval of longlines, } \\
\text { buoys and mooring }\end{array}$ & $\begin{array}{l}\text { Introduction of non-synthetic } \\
\text { substances and compounds }\end{array}$ & marine mammals & 0.389 & 54.59 & 905.08 \\
\hline 566 & $\begin{array}{l}\text { Instal: deployment longlines, } \\
\text { buoys and mooring }\end{array}$ & $\begin{array}{l}\text { Introduction of non-synthetic } \\
\text { substances and compounds }\end{array}$ & marine mammals & 0.389 & 54.59 & 905.08 \\
\hline 567 & $\begin{array}{l}\text { Op - inoculation: deployment of } \\
\text { the droppers }\end{array}$ & $\begin{array}{l}\text { Introduction of non-synthetic } \\
\text { substances and compounds }\end{array}$ & marine mammals & 0.389 & 54.59 & 905.08 \\
\hline 568 & Op - harvest: shipping & $\begin{array}{l}\text { Introduction of non-synthetic } \\
\text { substances and compounds }\end{array}$ & avial_migratory birds & 0.390 & 54.59 & 906.98 \\
\hline 569 & Op - harvest: shipping & $\begin{array}{l}\text { Introduction of non-synthetic } \\
\text { substances and compounds }\end{array}$ & avial_seabirds & 0.390 & 54.59 & 906.98 \\
\hline 570 & Op - inoculation: shipping & $\begin{array}{l}\text { Introduction of non-synthetic } \\
\text { substances and compounds }\end{array}$ & avial_migratory birds & 0.390 & 54.59 & 906.98 \\
\hline 571 & Op - inoculation: shipping & $\begin{array}{l}\text { Introduction of non-synthetic } \\
\text { substances and compounds }\end{array}$ & avial_seabirds & 0.390 & 54.59 & 906.98 \\
\hline 572 & Op - harvest: shipping & $\begin{array}{l}\text { Introduction of non-synthetic } \\
\text { substances and compounds }\end{array}$ & fish_adult & 0.390 & 54.59 & 906.98 \\
\hline 573 & Op - harvest: shipping & $\begin{array}{l}\text { Introduction of non-synthetic } \\
\text { substances and compounds }\end{array}$ & fish_juv & 0.390 & 54.59 & 906.98 \\
\hline 574 & Op - inoculation: shipping & $\begin{array}{l}\text { Introduction of non-synthetic } \\
\text { substances and compounds }\end{array}$ & fish_adult & 0.390 & 54.59 & 906.98 \\
\hline 575 & Op - inoculation: shipping & $\begin{array}{l}\text { Introduction of non-synthetic } \\
\text { substances and compounds }\end{array}$ & fish_juv & 0.390 & 54.59 & 906.98 \\
\hline 576 & Op - harvest: shipping & $\begin{array}{l}\text { Introduction of non-synthetic } \\
\text { substances and compounds }\end{array}$ & marine mammals & 0.390 & 54.59 & 906.98 \\
\hline 577 & Op - inoculation: shipping & $\begin{array}{l}\text { Introduction of non-synthetic } \\
\text { substances and compounds }\end{array}$ & marine mammals & 0.390 & 54.59 & 906.98 \\
\hline 578 & Op - cultivation: shipping & $\begin{array}{l}\text { Introduction of non-synthetic } \\
\text { substances and compounds }\end{array}$ & avial_migratory birds & 0.397 & 54.58 & 945.27 \\
\hline 579 & Op - cultivation: shipping & $\begin{array}{l}\text { Introduction of non-synthetic } \\
\text { substances and compounds }\end{array}$ & avial_seabirds & 0.397 & 54.58 & 945.27 \\
\hline 580 & Op - cultivation: shipping & $\begin{array}{l}\text { Introduction of non-synthetic } \\
\text { substances and compounds }\end{array}$ & fish_adult & 0.397 & 54.58 & 945.27 \\
\hline 581 & Op - cultivation: shipping & $\begin{array}{l}\text { Introduction of non-synthetic } \\
\text { substances and compounds }\end{array}$ & fish_juv & 0.397 & 54.58 & 945.27 \\
\hline 582 & Op - cultivation: shipping & $\begin{array}{l}\text { Introduction of non-synthetic } \\
\text { substances and compounds }\end{array}$ & marine mammals & 0.397 & 54.58 & 945.27 \\
\hline 583 & Decom: shipping & $\begin{array}{l}\text { Introduction of non-synthetic } \\
\text { substances and compounds }\end{array}$ & avial_migratory birds & 0.460 & 54.51 & 1282.27 \\
\hline 584 & Decom: shipping & $\begin{array}{l}\text { Introduction of non-synthetic } \\
\text { substances and compounds }\end{array}$ & avial_seabirds & 0.460 & 54.51 & 1282.27 \\
\hline 585 & Instal: shipping & $\begin{array}{l}\text { Introduction of non-synthetic } \\
\text { substances and compounds }\end{array}$ & avial_migratory birds & 0.460 & 54.51 & 1282.27 \\
\hline 586 & Instal: shipping & $\begin{array}{l}\text { Introduction of non-synthetic } \\
\text { substances and compounds }\end{array}$ & avial_seabirds & 0.460 & 54.51 & 1282.27 \\
\hline 587 & Decom: shipping & $\begin{array}{l}\text { Introduction of non-synthetic } \\
\text { substances and compounds }\end{array}$ & fish_adult & 0.460 & 54.51 & 1282.27 \\
\hline 588 & Decom: shipping & $\begin{array}{l}\text { Introduction of non-synthetic } \\
\text { substances and compounds }\end{array}$ & fish_juv & 0.460 & 54.51 & 1282.27 \\
\hline 589 & Instal: shipping & $\begin{array}{l}\text { Introduction of non-synthetic } \\
\text { substances and compounds }\end{array}$ & fish adult & 0.460 & 54.51 & 1282.27 \\
\hline 590 & Instal: shipping & $\begin{array}{l}\text { Introduction of non-synthetic } \\
\text { substances and compounds }\end{array}$ & fish_juv & 0.460 & 54.51 & 1282.27 \\
\hline 591 & Decom: shipping & $\begin{array}{l}\text { Introduction of non-synthetic } \\
\text { substances and compounds }\end{array}$ & marine mammals & 0.460 & 54.51 & 1282.27 \\
\hline 592 & Instal: shipping & $\begin{array}{l}\text { Introduction of non-synthetic } \\
\text { substances and compounds }\end{array}$ & marine mammals & 0.460 & 54.51 & 1282.27 \\
\hline 593 & $\begin{array}{l}\text { Op - cultivation: final growth } \\
\text { phase }\end{array}$ & $\mathrm{N} / \mathrm{P}$ depletion & water column & 0.000 & 1.00 & 1.42 \\
\hline 594 & $\begin{array}{l}\text { Op - cultivation: final growth } \\
\text { phase }\end{array}$ & N/P depletion & plankton & 0.001 & 1.00 & 1.52 \\
\hline 595 & $\begin{array}{l}\text { Op - cultivation: early growth } \\
\text { phase }\end{array}$ & $\mathrm{N} / \mathrm{P}$ depletion & plankton & 0.002 & 1.00 & 1.62 \\
\hline 596 & $\begin{array}{l}\text { Op - cultivation: early growth } \\
\text { phase }\end{array}$ & N/P depletion & water column & 0.002 & 1.00 & 1.62 \\
\hline
\end{tabular}




\begin{tabular}{|c|c|c|c|c|c|c|}
\hline 597 & $\begin{array}{l}\text { Op - cultivation: final growth } \\
\text { phase }\end{array}$ & N/P depletion & epiphytes \& epibionts & 0.025 & 3.50 & 8.42 \\
\hline 598 & $\begin{array}{l}\text { Op - cultivation: final growth } \\
\text { phase }\end{array}$ & N/P depletion & seaweed \& seagrass & 0.025 & 3.50 & 8.42 \\
\hline 599 & $\begin{array}{l}\text { Op - cultivation: early growth } \\
\text { phase }\end{array}$ & N/P depletion & epiphytes \& epibionts & 0.042 & 3.50 & 9.02 \\
\hline 600 & $\begin{array}{l}\text { Op - cultivation: early growth } \\
\text { phase }\end{array}$ & N/P depletion & seaweed \& seagrass & 0.042 & 3.50 & 9.02 \\
\hline 601 & $\begin{array}{l}\text { Decom: retrieval of longlines, } \\
\text { buoys and mooring }\end{array}$ & Nitrogen emission \& deposition & terrestrial & 0.015 & 3.47 & 57.10 \\
\hline 602 & Decom: shipping & Nitrogen emission \& deposition & terrestrial & 0.015 & 3.47 & 57.10 \\
\hline 603 & $\begin{array}{l}\text { Instal: deployment longlines, } \\
\text { buoys and mooring }\end{array}$ & Nitrogen emission \& deposition & terrestrial & 0.015 & 3.47 & 57.10 \\
\hline 604 & Op - cultivation: monitoring & Nitrogen emission \& deposition & terrestrial & 0.028 & 3.47 & 57.17 \\
\hline 605 & Op - harvest: mechanical harvest & Nitrogen emission \& deposition & terrestrial & 0.028 & 3.47 & 57.17 \\
\hline 606 & Op - harvest: shipping & Nitrogen emission \& deposition & terrestrial & 0.028 & 3.47 & 57.17 \\
\hline 607 & $\begin{array}{l}\text { Op - inoculation: deployment of } \\
\text { the droppers }\end{array}$ & Nitrogen emission \& deposition & terrestrial & 0.028 & 3.47 & 57.17 \\
\hline 608 & Op - inoculation: shipping & Nitrogen emission \& deposition & terrestrial & 0.028 & 3.47 & 57.17 \\
\hline 609 & $\begin{array}{l}\text { Op - cultivation: early growth } \\
\text { phase }\end{array}$ & Nitrogen emission \& deposition & terrestrial & 0.108 & 3.47 & 57.77 \\
\hline 610 & Op - cultivation: shipping & Nitrogen emission \& deposition & terrestrial & 0.108 & 3.47 & 57.77 \\
\hline 611 & $\begin{array}{l}\text { Op - cultivation: final growth } \\
\text { phase }\end{array}$ & Nitrogen emission \& deposition & terrestrial & 0.028 & 3.47 & 57.78 \\
\hline 612 & Instal: shipping & Nitrogen emission \& deposition & terrestrial & 0.017 & 3.47 & 98.64 \\
\hline 613 & $\begin{array}{l}\text { Decom: retrieval of longlines, } \\
\text { buoys and mooring }\end{array}$ & $\begin{array}{l}\text { Physical disturbance to seabed } \\
\text { (temporary or reversible) }\end{array}$ & hard sub & 0.000 & 3.50 & 0.90 \\
\hline 614 & $\begin{array}{l}\text { Instal: deployment longlines, } \\
\text { buoys and mooring }\end{array}$ & $\begin{array}{l}\text { Physical disturbance to seabed } \\
\text { (temporary or reversible) }\end{array}$ & hard sub & 0.000 & 3.50 & 0.90 \\
\hline 615 & $\begin{array}{l}\text { Decom: retrieval of longlines, } \\
\text { buoys and mooring }\end{array}$ & $\begin{array}{l}\text { Physical disturbance to seabed } \\
\text { (temporary or reversible) }\end{array}$ & benthos_on & 0.000 & 3.50 & 0.95 \\
\hline 616 & $\begin{array}{l}\text { Decom: retrieval of longlines, } \\
\text { buoys and mooring }\end{array}$ & $\begin{array}{l}\text { Physical disturbance to seabed } \\
\text { (temporary or reversible) }\end{array}$ & soft sed & 0.004 & 3.50 & 1.49 \\
\hline 617 & $\begin{array}{l}\text { Instal: deployment longlines, } \\
\text { buoys and mooring }\end{array}$ & $\begin{array}{l}\text { Physical disturbance to seabed } \\
\text { (temporary or reversible) }\end{array}$ & soft sed & 0.004 & 3.50 & 1.49 \\
\hline 618 & $\begin{array}{l}\text { Instal: deployment longlines, } \\
\text { buoys and mooring }\end{array}$ & $\begin{array}{l}\text { Physical disturbance to seabed } \\
\text { (temporary or reversible) }\end{array}$ & benthos_on & 0.004 & 3.50 & 1.52 \\
\hline 619 & $\begin{array}{l}\text { Op - cultivation: final growth } \\
\text { phase }\end{array}$ & Reduction in wave energy & plankton & 0.001 & 1.00 & 1.52 \\
\hline 620 & $\begin{array}{l}\text { Op - cultivation: early growth } \\
\text { phase }\end{array}$ & Reduction in wave energy & plankton & 0.002 & 1.00 & 1.62 \\
\hline 621 & $\begin{array}{l}\text { Op - cultivation: final growth } \\
\text { phase }\end{array}$ & Reduction in wave energy & soft sed & 0.027 & 3.50 & 9.01 \\
\hline 622 & $\begin{array}{l}\text { Op - cultivation: early growth } \\
\text { phase }\end{array}$ & Reduction in wave energy & soft sed & 0.045 & 3.50 & 9.61 \\
\hline 623 & Op - harvest: mechanical harvest & Release of reproductive material & seaweed \& seagrass & 0.127 & 5.95 & 60.96 \\
\hline 624 & $\begin{array}{l}\text { Op - cultivation: final growth } \\
\text { phase }\end{array}$ & Shading & plankton & 0.000 & 1.00 & 0.26 \\
\hline 625 & $\begin{array}{l}\text { Op - cultivation: early growth } \\
\text { phase }\end{array}$ & Shading & plankton & 0.000 & 1.00 & 0.36 \\
\hline 626 & $\begin{array}{l}\text { Op - cultivation: final growth } \\
\text { phase }\end{array}$ & Shading & epiphytes \& epibionts & 0.000 & 3.50 & 0.91 \\
\hline 627 & $\begin{array}{l}\text { Op - cultivation: final growth } \\
\text { phase }\end{array}$ & Shading & seaweed \& seagrass & 0.000 & 3.50 & 0.91 \\
\hline 628 & $\begin{array}{l}\text { Op - cultivation: early growth } \\
\text { phase }\end{array}$ & Shading & epiphytes \& epibionts & 0.000 & 3.50 & 1.51 \\
\hline 629 & $\begin{array}{l}\text { Op - cultivation: early growth } \\
\text { phase }\end{array}$ & Shading & seaweed \& seagrass & 0.000 & 3.50 & 1.51 \\
\hline 630 & $\begin{array}{l}\text { Op - cultivation: final growth } \\
\text { phase }\end{array}$ & $\begin{array}{l}\text { Water flow rate changes and/or } \\
\text { direction }\end{array}$ & soft sed & 0.027 & 3.50 & 9.01 \\
\hline 631 & $\begin{array}{l}\text { Op - cultivation: early growth } \\
\text { phase }\end{array}$ & $\begin{array}{l}\text { Water flow rate changes and/or } \\
\text { direction }\end{array}$ & soft sed & 0.045 & 3.50 & 9.61 \\
\hline
\end{tabular}




\section{Annex 5 Overview of pressures and related ecosystem components that occur in impact risk chains}

Annex 5: Overview of pressures and related ecosystem components that occur in impact risk (IR) chains per IR category calculated with different methods (instant IR_1 and long-term IR vs instant IR_2). Total IC denotes total number of impact chains.

\begin{tabular}{|c|c|c|c|c|c|}
\hline $\begin{array}{l}\text { Impact } \\
\text { Risk }\end{array}$ & Method & Pressure (number of impact chains) & EC & Activities & $\begin{array}{c}\text { Total } \\
\text { IC }\end{array}$ \\
\hline \multirow[t]{3}{*}{ High } & $\begin{array}{l}\text { Instant } \\
\text { IR_2 }\end{array}$ & $\begin{array}{l}\text { Introduction of non-synthetic substances and } \\
\text { compounds (10) }\end{array}$ & $\begin{array}{l}\text { Fish (4), avial animals } \\
(4), \text { marine mammals (2) }\end{array}$ & $\begin{array}{l}\text { Dec-shipping (5), Ins- } \\
\text { shipping (5) }\end{array}$ & 10 \\
\hline & $\begin{array}{l}\text { Instant } \\
\text { IR_1 }\end{array}$ & $\begin{array}{l}\text { Introduction of non-synthetic substances and } \\
\text { compounds (48), Input of litter (44) }\end{array}$ & $\begin{array}{l}\text { Avial animals (38), fish } \\
\text { (27), marine mammals } \\
\text { (19), benthos (5), soft } \\
\text { sediment (3) }\end{array}$ & $\begin{array}{l}\text { Dec-shipping (8), Dec-man } \\
\text { lab (4), Dec-retrieval } \\
\text { system (9), Inst-depl (9), } \\
\text { Inst-man lab (4), Instal- } \\
\text { shipping (8), Op-cult early } \\
\text { growth (4), Op-cult final } \\
\text { growth (4), Op-cult man } \\
\text { lab (4), Op-cult shipping } \\
\text { (7), Op-harv man lab (4), } \\
\text { Op-harv mech (4), Op-harv } \\
\text { shipping (5), Op-in depl } \\
\text { (8), Op-in depl (9), Op-in } \\
\text { man lab (4), Op-in shipping } \\
\text { (5) }\end{array}$ & 92 \\
\hline & $\begin{array}{l}\text { Long- } \\
\text { term IR }\end{array}$ & $\begin{array}{l}\text { Input of litter (44), Introduction of non-synthetic } \\
\text { substances and compounds (40), Absorption of trace and } \\
\text { heavy metals (4) }\end{array}$ & $\begin{array}{l}\text { Avial animals (38), fish } \\
\text { (31), marine mammals } \\
\text { (19) }\end{array}$ & $\begin{array}{l}\text { Dec-shipping (5), Dec-man } \\
\text { lab (4), Dec-retrieval } \\
\text { system (9), Inst-depl (9), } \\
\text { Inst-man lab (4), Instal- } \\
\text { shipping (5), Op-cult early } \\
\text { growth (6), Op-cult final } \\
\text { growth (6), Op-cult man } \\
\text { lab (4), Op-cult shipping } \\
\text { (5), Op-harv man lab (4), } \\
\text { Op-harv mech (4), Op-harv } \\
\text { shipping (5), Op-in depl } \\
\text { (8), Op-in depl (9), Op-in } \\
\text { man lab (4), Op-in shipping } \\
\text { (5) }\end{array}$ & 88 \\
\hline \multirow[t]{3}{*}{$\begin{array}{l}\text { Medium- } \\
\text { high }\end{array}$} & $\begin{array}{l}\text { Instant } \\
\text { IR_2 }\end{array}$ & $\begin{array}{l}\text { Input of litter (44), Introduction of non-synthetic } \\
\text { substances and compounds (30) }\end{array}$ & $\begin{array}{l}\text { Avial animals (34), fish } \\
\text { (23), marine mammals } \\
\text { (17) }\end{array}$ & $\begin{array}{l}\text { Dec-man lab (4), Dec- } \\
\text { retrieval system (18), Inst- } \\
\text { depl (9), Inst-man lab (4), } \\
\text { Op-cult early growth (4), } \\
\text { Op-cult final growth (4), } \\
\text { Op-cult man lab (4), Op- } \\
\text { cult shipping (5), Op-harv } \\
\text { man lab (4), Op-harv mech } \\
\text { (4), Op-harv shipping (5), } \\
\text { Op-in depl (8), Op-in man } \\
\text { lab (4), Op-in shipping (5) }\end{array}$ & 74 \\
\hline & $\begin{array}{l}\text { Instant } \\
\text { IR_1 }\end{array}$ & $\begin{array}{l}\text { Introduction of non-synthetic substances and } \\
\text { compounds (48), Input of anthropogenic sound (12), } \\
\text { Input of light (12), Disturbance (visual) of fauna (12), } \\
\text { Death or injury by collision (2) }\end{array}$ & $\begin{array}{l}\text { Avial animals (18), } \\
\text { benthos (11), fish (8), } \\
\text { marine mammals (8), } \\
\text { seaweed (8), epiphytes } \\
\text { (8), hard substrate (8), } \\
\text { terrestrial (8), soft } \\
\text { sediment (5) }\end{array}$ & $\begin{array}{l}\text { Dec-retrieval system (7), } \\
\text { Dec-shipping (21), Inst- } \\
\text { depl (7), Op-cult shipping } \\
\text { (5), Op-harv shipping (7), } \\
\text { Op-in depl (7), Op-in } \\
\text { shipping (7) }\end{array}$ & 82 \\
\hline & $\begin{array}{l}\text { Long- } \\
\text { term IR }\end{array}$ & & & & 0 \\
\hline \multirow[t]{3}{*}{ Medium } & $\begin{array}{l}\text { Instant } \\
\text { IR_2 }\end{array}$ & & & & 0 \\
\hline & $\begin{array}{l}\text { Instant } \\
\text { IR_1 }\end{array}$ & & & & 0 \\
\hline & $\begin{array}{l}\text { Long- } \\
\text { term IR }\end{array}$ & $\begin{array}{l}\text { Input of anthropogenic sound (60), Input of litter (44), } \\
\text { Input of light (42), Input or spread of non-indigenous } \\
\text { species (40), Disturbance (visual) of fauna (40), } \\
\text { Introduction of non-synthetic substances and } \\
\text { compounds (34), Attraction of species (15), Absorption }\end{array}$ & $\begin{array}{l}\text { Avial animals (93), fish } \\
(49), \text { marine mammals } \\
(43), \text { benthos (36), soft } \\
\text { sediment (21), hard } \\
\text { substrate (21), seaweed }\end{array}$ & $\begin{array}{l}\text { Dec-man lab (4), Dec- } \\
\text { retrieval system (17), Dec- } \\
\text { shipping (26), Inst-depl } \\
(21) \text {, Inst-man lab (4), } \\
\text { instal-shipping (26), Op- }\end{array}$ & 321 \\
\hline
\end{tabular}




\begin{tabular}{|c|c|c|c|c|c|}
\hline & & $\begin{array}{l}\text { of trace and heavy metals (14), Entanglement (8), Barrier } \\
\text { to species movement (6), Death or injury by collision (6), } \\
\text { Extraction of food resource (5), Input of genetically } \\
\text { modified species and translocation of native seaweed } \\
\text { species (4), Extraction of, or mortality/injury to, wild } \\
\text { species (3) }\end{array}$ & $\begin{array}{l}\text { (13), terrestrial (13), } \\
\text { water column (13), } \\
\text { plankton (10), epiphytes } \\
\text { (9) }\end{array}$ & $\begin{array}{l}\text { cult early growth (37), Op- } \\
\text { cult final growth (44), Op- } \\
\text { cult man lab (10), Op-cult } \\
\text { shipping (26), Op-harv } \\
\text { man lab (4), Op-harv mech } \\
\text { (27), Op-harv shipping } \\
\text { (28), Op-in depl (24), Op-in } \\
\text { man lab (4), Op-in shipping } \\
\text { (29) }\end{array}$ & \\
\hline \multirow[t]{3}{*}{$\begin{array}{l}\text { Medium- } \\
\text { low }\end{array}$} & $\begin{array}{l}\text { Instant } \\
\text { IR_2 }\end{array}$ & $\begin{array}{l}\text { Input of anthropogenic sound (12), Input of light (12), } \\
\text { Disturbance (visual) of fauna (8), Absorption of trace and } \\
\text { heavy metals (4), Death or injury by collision ( } 2 \text { ) }\end{array}$ & $\begin{array}{l}\text { Avial animals (18), fish } \\
\text { (12), marine mammals } \\
\text { (8) }\end{array}$ & $\begin{array}{l}\text { Dec-shipping (17), Instal- } \\
\text { shipping (17), Op-cult early } \\
\text { growth (2), Op-cult final } \\
\text { growth (2) }\end{array}$ & 38 \\
\hline & $\begin{array}{l}\text { Instant } \\
\text { IR_1 }\end{array}$ & $\begin{array}{l}\text { Input or spread of non-indigenous species (32), Input of } \\
\text { genetically modified species and translocation of native } \\
\text { seaweed species (4), Carbon emission (4), Nitrogen } \\
\text { emission \& deposition (2), Release of reproductive } \\
\text { material (1) }\end{array}$ & $\begin{array}{l}\text { Benthos (16), epiphytes } \\
\text { (10), seaweed (15), } \\
\text { terrestrial (2) }\end{array}$ & $\begin{array}{l}\text { Dec-shipping (4), Instal- } \\
\text { shipping (4), Op-cult early } \\
\text { growth (8), Op-cult final } \\
\text { growth (5) Op-cult } \\
\text { shipping (7), Op-harv mech } \\
\text { (2), Op-harv shipping (4), } \\
\text { Op-in depl (5), Op-in } \\
\text { shipping (4) }\end{array}$ & 43 \\
\hline & $\begin{array}{l}\text { Long- } \\
\text { term IR }\end{array}$ & & & & 0 \\
\hline \multirow[t]{3}{*}{ Low } & $\begin{array}{l}\text { Instant } \\
\text { IR_2 }\end{array}$ & $\begin{array}{l}\text { Introduction of non-synthetic substances and } \\
\text { compounds (72), Input of anthropogenic sound (69), } \\
\text { Carbon emission (48), Input of litter (44), Input or } \\
\text { spread of non-indigenous species (40), Input of light } \\
\text { (37), Death or injury by collision (36), Attraction of } \\
\text { species (21), Input of microbial pathogens \& parasites } \\
\text { (20), Input of organic matter (15), Absorption of trace } \\
\text { and heavy metals (14), Nitrogen emission \& deposition } \\
\text { (12), Changes in siltation (10), Entanglement (10), } \\
\text { Extraction of, or mortality/injury to, wild species (9), N/P } \\
\text { depletion (8), Carbon capture (8), Extraction of food } \\
\text { resource (7), Physical disturbance to seabed (6), Barrier } \\
\text { to species movement (6), Shading (6), Input of } \\
\text { genetically modified species and translocation of native } \\
\text { seaweed species (4), Reduction in wave energy (4), } \\
\text { Water flow rate changes and/or direction (2), Release of } \\
\text { reproductive material (1) }\end{array}$ & $\begin{array}{l}\text { Benthos (81), avial } \\
\text { animals (75), seaweed } \\
\text { (54), epiphytes (51), } \\
\text { plankton (41), fish (41), } \\
\text { water column (40), } \\
\text { marine mammals (35), } \\
\text { soft sediment (35), } \\
\text { terrestrial (33), hard } \\
\text { substrate (23) }\end{array}$ & $\begin{array}{l}\text { Dec-man lab (4), Dec- } \\
\text { retrieval system (40), Dec- } \\
\text { shipping (24), Inst-depl } \\
\text { (44), Inst-man lab (4), Inst- } \\
\text { shipping (24), Op-cult early } \\
\text { growth (68), Op-cult final } \\
\text { growth (68), Op-cult man } \\
\text { lab (12), Op-cult mon (5), } \\
\text { Op-cult shipping (41), Op- } \\
\text { harv man lab (4), Op-harv } \\
\text { mech (44), Op-harv } \\
\text { shipping (41), Op-in depl } \\
\text { (41), Op-in man lab (4), } \\
\text { Op-in shipping (41) }\end{array}$ & 509 \\
\hline & $\begin{array}{l}\text { Instant } \\
\text { IR_1 }\end{array}$ & $\begin{array}{l}\text { Input of anthropogenic sound (69), Carbon emission } \\
\text { (44), Input of litter (44), Input of light (37), Disturbance } \\
\text { (visual) of fauna (32), Attraction of species (21), Input of } \\
\text { microbial pathogens \& parasites (20), Absorption of } \\
\text { trace and heavy metals (18), Introduction of non- } \\
\text { synthetic substances and compounds (16), Input of } \\
\text { organic matter (15), Nitrogen emission \& deposition } \\
\text { (12), Entanglement (10), Changes in siltation (10), } \\
\text { Extraction of, or mortality/injury to, wild species (9), } \\
\text { Carbon capture (8), N/P depletion (8), Input or spread of } \\
\text { non-indigenous species (8), Extraction of food resource } \\
\text { (7), Barrier to species movement (6), Physical } \\
\text { disturbance to seabed (6), Shading (6), Death or injury by } \\
\text { collision (4), Reduction in wave energy (4), Water flow } \\
\text { rate changes and/or direction (2) }\end{array}$ & $\begin{array}{l}\text { Avial animals (81), } \\
\text { benthos (49), fish (45), } \\
\text { water column (40), } \\
\text { plankton (41), marine } \\
\text { mammals (35), } \\
\text { epiphytes (33), seaweed } \\
\text { (31), soft sediment (27), } \\
\text { terrestrial (23), hard } \\
\text { substrate (10) }\end{array}$ & $\begin{array}{l}\text { Dec-man lab (4), Dec- } \\
\text { retrieval system (35), Dec- } \\
\text { shipping (13), Inst-depl } \\
\text { (37), Inst-man lab (4), Inst- } \\
\text { shipping (13), Op-cult early } \\
\text { growth (62), Op-cult final } \\
\text { growth (65), Op-cult man } \\
\text { lab (12), Op-cult mon (5), } \\
\text { Op-cult shipping (27), Op- } \\
\text { harv man lab (4), Op-harv } \\
\text { mech (42), Op-harv } \\
\text { shipping (30), Op-in depl } \\
\text { (29), Op-in man lab (4), } \\
\text { Op-in shipping (30) }\end{array}$ & 414 \\
\hline & $\begin{array}{l}\text { Long- } \\
\text { term IR }\end{array}$ & $\begin{array}{l}\text { Carbon emission (48), Introduction of non-synthetic } \\
\text { substances and compounds (38), Input of anthropogenic } \\
\text { sound (21), Input of microbial pathogens \& parasites } \\
\text { (20), Input of organic matter (15), Nitrogen emission \& } \\
\text { deposition (12), Changes in siltation (10), Carbon capture } \\
\text { (8), N/P depletion (8), Input of light (7), Attraction of } \\
\text { species (6), Extraction of, or mortality/injury to, wild } \\
\text { species (6), Physical disturbance to seabed (6), Shading } \\
\text { (6), Reduction in wave energy (4), Entanglement (2), } \\
\text { Extraction of food resource (2), Water flow rate changes } \\
\text { and/or direction (2), Release of reproductive material (1) }\end{array}$ & $\begin{array}{l}\text { Benthos (45), epiphytes } \\
(42), \text { seaweed (41), } \\
\text { plankton (31), water } \\
\text { column (27), terrestrial } \\
\text { (20), soft sediment (14), } \\
\text { hard substrate (2) }\end{array}$ & & 222 \\
\hline
\end{tabular}




\section{Annex 6 Risk ranking Campbell et al 2019}

Annex 6: Risk ranking of seaweed farming impact pathways from Campbell et al. 2019.

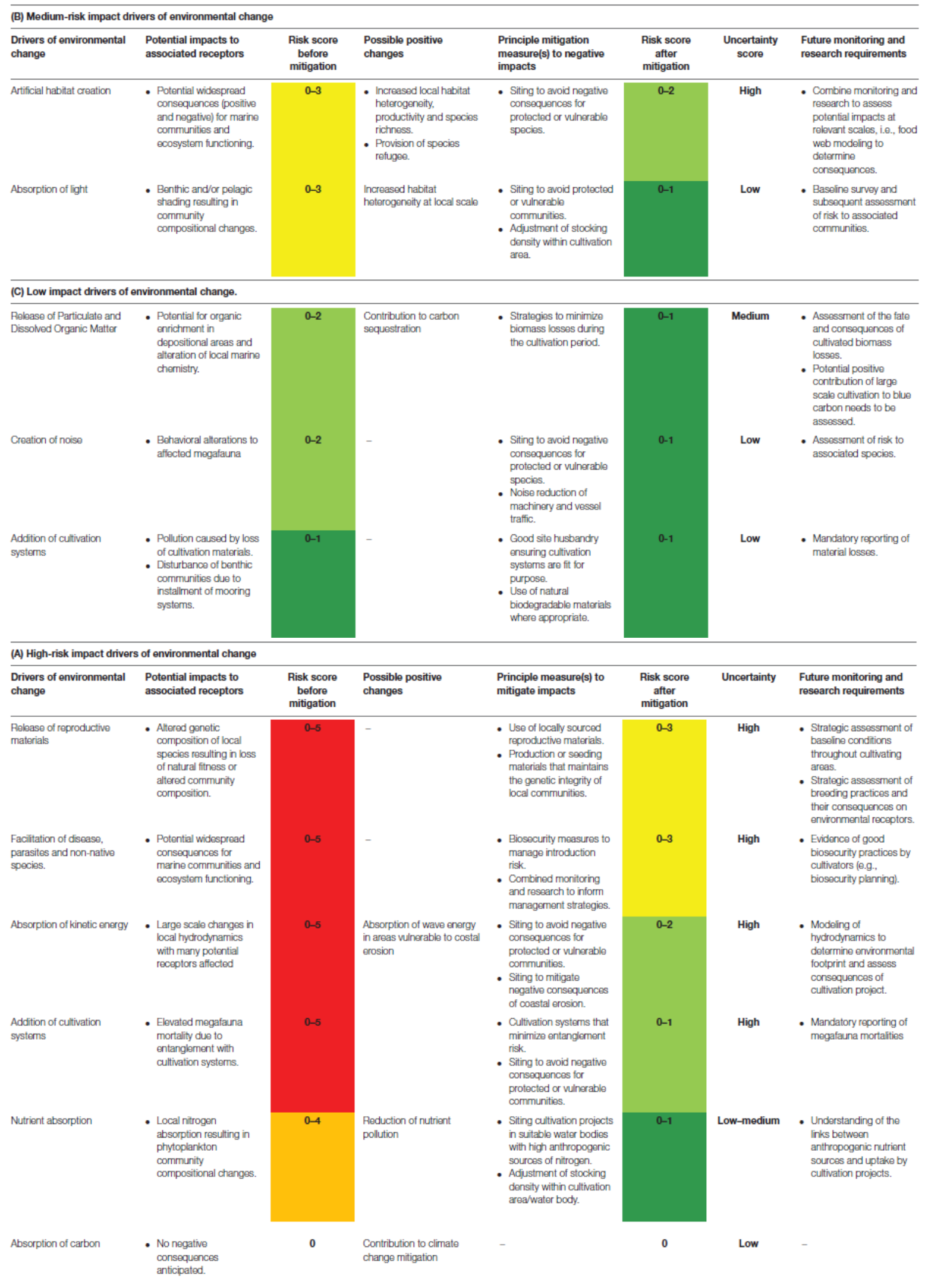

A hypothetical risk assessment of a large scale cultivation project (100 ha) is shown in the table above. Risk scores summarize only negative changes and are based on the potential vulherability of associated receptors along with the magnitude of potential change $(0=$ no negative consequences likaly, $1=$ consequences possible for some receptors, $2=$ negative consequences possible for receptors requiring miligation, $3=$ widespread negative consequences possible for receptors requiring mitigation, $4=$ negative consequencess possible for protected receptors requiring mifigation, $5=$ widaspread negative consequences possible for monitoring, and research needed to adress uncertainty is highlighted. 
Wageningen Marine Research

$\mathrm{T}+31(0) 317487000$

E: marine-research@wur.nl

www.wur.eu/marine-research

Visitors' address

- Ankerpark 271781 AG Den Helder

- Korringaweg 7, 4401 NT Yerseke

- Haringkade 1, 1976 CP IJmuiden
With knowledge, independent scientific research and advice, Wageningen Marine Research substantially contributes to more sustainable and more careful management, use and protection of natural riches in marine, coastal and freshwater areas. Wageningen Marine Research is part of Wageningen University \& Research. Wageningen University \& Research is the collaboration between Wageningen University and the Wageningen Research Foundation and its mission is: 'To explore the potential for improving the quality of life' 